LARISSA VEREA

\title{
O AUMENTO DOS PODERES DO RELATOR E O JULGAMENTO MONOCRÁTICO DOS RECURSOS CÍVEIS
}

\author{
DISSERTAÇÃO DE MESTRADO
}

Orientador Prof. Dr. Antonio Carlos Marcato

Faculdade de Direito da Universidade de São Paulo

SÃo PaUlo

2014 
LARISSA VEREA

\section{O AUMENTO DOS PODERES DO RELATOR E O JULGAMENTO MONOCRÁTICO DOS RECURSOS CÍVEIS}

Dissertação apresentada como requisito para obtenção do grau de mestre em direito pelo programa de pós-graduação da Faculdade de Direito da Universidade de São Paulo

\section{ORIENTADOR PROF. DR. ANTONIO CARLOS MARCATO}

FACUldade DE DiREITO dA UniVERSIDAdE DE SÃo PAUlo

SÃo PAULO

2014 
Ao meu irmão Gabriel, meu melhor amigo para toda a vida. 


\section{AGRADECIMENTOS}

Agradeço, sobretudo, a minha avó materna BERnARDETTA, meu exemplo de vida, que sempre me ensinou que conhecimento é o maior bem que uma pessoa pode ter; a minha mãe, EUGENIA, por seu amor, dedicação, sacrifício e companheirismo; e a meu irmão, GABRIEL, que sempre me estimulou a ser uma pessoa melhor em tudo aquilo que faço.

Agradeço, também, meu orientador, Professor AnTONio CARlos MARCATO, pela oportunidade e em cujo exemplo me espelho na busca de aprofundamento no estudo do processo civil e por quem nutro grande admiração.

A minha professora, mentora, chefe e amiga HELENA NAJJAR ABDO, pelos inúmeros votos de confiança em mim depositados mesmo antes do meu ingresso no curso de mestrado na Faculdade de Direito da Universidade de São Paulo, bem como pelo exemplo de acadêmica, profissional e amiga.

Aos professores José Carlos Baptista Puoli e Rodolfo de Camargo Mancuso, pelas diversas conversas acadêmicas e oportunidades que me foram dadas e que contribuíram - e contribuem - sobremaneira para meu aprimoramento como estudiosa do direito processual civil.

Ao Desembargador RiCARdo CinTRA TORRES DE CARVAlHO, por me fazer ver o direito de outro ângulo e compreender o verdadeiro significado da palavra "justiça".

Ao meu colega Pedro Paulo Wendel Gasparini, por me acolher quando decidi retornar à advocacia e por me incentivar continuamente, contribuindo sobremaneira para meu desenvolvimento profissional.

Aos amigos BAyeuX, IsABella, DÉBORA E DANIElle, que compartilharam da minha angústia nos momentos finais antes do depósito da dissertação e me ajudaram, cada qual a sua maneira, a concretizar este trabalho. 


\section{RESUMO}

O processo civil brasileiro tem sofrido contínuas alterações, sempre com vistas à busca de maior celeridade e efetividade jurisdicional. $\mathrm{O}$ aumento dos poderes do relator no julgamento dos recursos cíveis foi uma das formas encontradas para se acelerar a prestação jurisdicional e desobstruir a pauta dos Tribunais, hoje assolados por uma enorme quantidade de recursos. No entanto, as modificações da legislação que ampliaram os poderes do relator não escaparam às críticas da doutrina, seja por conta das deficiências da redação do dispositivo, seja do alcance prático do julgamento monocrático, chegando até mesmo a ter sua constitucionalidade questionada. O trabalho aborda essas questões trazendo um olhar contemporâneo e reflexivo sobre o tema.

Palavras chave: Processo civil. Recurso. Duplo grau de jurisdição. Julgamento. Relator. Decisão monocrática. 


\begin{abstract}
The Brazilian civil procedure has undergone continuous changes, always seeking celerity and effectiveness. The increase of the powers of the rapporteur in the trial of civil appeals was one of the resources used to accelerate the judiciary relief and unclog the Courts' agenda, currently plagued by a huge amount of appeals. However, changes in the law that expanded the powers of the rapporteur did not escape the doctrine's criticism, whether on account of the wording deficiencies or on the practical effect of the judgment, having even its constitutionality questioned. This paper addresses these issues under a contemporary and reflexive right.
\end{abstract}

Keywords: Civil procedure. Appeal. Trial. Monocratic decision. Single decision. 


\section{Introdução}

\section{Capítulo 1 - O duplo grau de jurisdição}

1. Conceito de duplo grau de jurisdição

2. A expressão "duplo grau de jurisdição"

3. Fundamentos do duplo grau de jurisdição

4. Argumentos favoráveis à adoção do duplo grau de jurisdição

4.1. Benefício psicológico às partes

4.2. Maior experiência dos julgadores do órgão ad quem

4.3. Possibilidade de erro do juiz de primeira instância

4.4. Controle das decisões dos juízes de primeira instância

4.5. Maior exame da decisão

4.6. Uniformização da jurisprudência

5. Argumentos desfavoráveis à adoção do duplo grau de jurisdição

5.1. Maior demora na solução do litígio

5.2. Ausência dos benefícios decorrentes da oralidade, da imediação e concentração dos atos processuais

5.3. Inutilidade do acórdão que confirma uma sentença justa e possibilidade de o órgão ad quem substituir uma sentença justa por um acórdão injusto

5.4. Desprestígio do magistrado de primeira instância

6. Princípio ou garantia constitucional?

\section{Capítulo 2 - A opção pelo julgamento colegiado dos recursos}

1. O julgamento colegiado - razões e justificativas

2. Os poderes do relator no direito estrangeiro

2.1. Europa

2.2. Estados Unidos 


\section{Capítulo 3 - Mitigação da colegialidade e ampliação dos poderes do relator}

1. A realidade forense e a crise do Poder Judiciário

2. O acesso à justiça, a efetividade e a razoável duração do processo

2.1. Conteúdo e alcance

2.2. Efetividade da razoável duração do processo

2.3. Conselho Nacional de Justiça e a efetivação do princípio

2.4. Celeridade e recursos protelatórios

2.5. Celeridade no Projeto do 'novo' Código de Processo Civil

\section{Capítulo 4 - A ampliação dos poderes do relator}

1. As atribuições do relator

2. Histórico do artigo 557 do Código de Processo Civil

2.1. Antecedentes históricos

2.2. Antecedentes do artigo 557 do Código de Processo Civil (em sua redação atual)

2.3. O artigo 557 do Código de Processo Civil

2.3.1 A redação original do artigo 557 do Código de Processo Civil

2.3.2. Notas sobre as Reformas do Código de Processo Civil

2.3.3. As alterações promovidas pela Lei $\mathrm{n}^{\circ}$ 9.139/95

2.3.4. As alterações promovidas pela Lei $n^{\circ}$ 9.756/98

2.4. As propostas de alteração do artigo 557 do Código de Processo Civil (PL n ${ }^{\circ}$ 8.046/10)

3. A constitucionalidade do artigo 557 do Código de Processo Civil 


\section{Capítulo 5 - Análise do artigo 557 do Código de Processo Civil}

1. As deficiências de redação do artigo 557 do Código de Processo Civil

1.1. O sentido das expressões "manifestamente" e "manifesto"

1.2. O sentido da expressão "negar seguimento"

2. Recurso manifestamente inadmissível

3. Recurso manifestamente prejudicado

4. Recurso manifestamente improcedente

5. Recurso em manifesto "confronto" com súmula

6. Recurso em manifesto "confronto" com jurisprudência dominante

7. Decisão recorrida em manifesto "confronto" com súmula ou jurisprudência dominante do Supremo Tribunal Federal e/ou de Tribunais Superiores

Capítulo 6 - O julgamento monocrático do recurso realizado com base no artigo 557 do Código de Processo Civil

1. Competência do relator

2. Faculdade ou dever do relator?

3. Alcance da decisão do relator

3.1. Reexame necessário

4. Motivação da decisão monocrática

\section{Capítulo 7 - Impugnação da decisão monocrática}

1. Agravo

1.1 Terminologia

1.2. Processamento

1.2.1 Juízo de retratação

1.2.2. Efeitos 


\subsubsection{Aspectos polêmicos}

2. A aplicação de multa nos casos de interposição de agravo manifestamente inadmissível ou infundado

\section{Capítulo 8 - Questões polêmicas relacionadas à aplicação do artigo 557 do Código de} Processo Civil

1. A possibilidade de aplicação do disposto no artigo $515 \S 3^{\circ}$ do Código de Processo Civil

2. O julgamento do agravo retido

3. Cabimentos dos embargos de declaração

4. Cabimento dos embargos infringentes e de divergência

5. Momento de apreciação da existência de repercussão geral

6. A possibilidade de aplicação do disposto no artigo 285-A do Código de Processo Civil

\section{Conclusão}

\section{Bibliografia}




\section{INTRODUÇÃO}

O tema objeto de nosso estudo compreende a análise da ampliação dos poderes do relator e das hipóteses de julgamento monocrático dos recursos na esfera cível, com enfoque na aplicação do atual artigo 557 do Código de Processo Civil.

Razões de política legislativa impõem que determinadas decisões judiciais sejam proferidas monocraticamente ou, então, por órgãos colegiados. Em nosso país, tradicionalmente, o julgamento dos recursos é realizado por um órgão colegiado e não por um de seus membros ${ }^{1}$.

O termo "colegiado" diz respeito a uma forma de atuação jurisdicional, em que pessoas com igual poder, reunidas em sessão de julgamento, compartilham os fatos do processo como "expressão de uma vontade unitária"2 3. O pronunciamento do órgão colegiado forma-se progressivamente, à medida que cada integrante manifesta seu entendimento durante a sessão de julgamento.

São valiosos os ensinamentos de Pontes de Miranda sobre o tema: "a regra, para os recursos, é a colegialidade das decisões. Quer dizer: a pluralidade dos julgadores, com o fim politico de assegurar diversos exames no mesmo tempo, além do duplo ou múltiplo exame, no tempo, pelo juiz do primeiro grau e os demais juízes superiores. A ciência ensina-nos, hoje, que a assembleia não nos veio da reflexão; foi a reflexão que veio da assembleia. Portanto, o homem é que é produto da assembleia. Essa prioridade do exame múltiplo ao mesmo tempo, em relação ao exame de um só, se transforma em superioridade sempre que desejamos maior

\footnotetext{
${ }^{1}$ CARVALHO, Fabiano. A função do relatório no julgamento colegiado. Manifestação do princípio do contraditório. Revista de Processo, São Paulo, v.36, n.198, ago. 2011, p. 445.

${ }^{2}$ Idem, p.446.

${ }^{3}$ (...) "o órgão colegiado é composto pelo numero de juízes que a lei ou o regimento interno indicar. Nem sempre todos os juízes que compõem órgão colegiado julgam a causa. Turma julgadora é a fração do órgão colegiado composta pelos juízes que efetivamente julgarão a causa. Numa Câmara composta por cinco juízes, por exemplo, a Turma julgadora de apelação será composta por apenas três deles; em sua composição plena (cinco juízes), essa mesma Câmara julgara, por exemplo, ação rescisória, embargos infringentes etc.” (NERY JUNIOR, Nelson; NERY, Rosa Maria de Andrade. Código de Processo Civil comentado e legislação extravagante. $9^{a}$ ed. São Paulo: RT, 2006, p. 927).
} 
certeza. A colegialidade para a decisão dos recursos obedece a esse pendor ultimo do homem, quando se deseja guiar pela razão"4.

Há países que adotam o sistema dos juízos colegiados desde o primeiro grau de jurisdição "como, v.g., Portugal e França", na suposição de que assim restaria mais bem assegurada a justiça da prestação jurisdicional, melhor seriam analisadas as questões de fato, reservando-se o reexame recursal, em algumas legislações, apenas ou quase sempre somente às questões de direito"

No Brasil, o sistema recursal brasileiro tradicionalmente consagrava o julgamento colegiado, tanto que a competência, para decidir sobre o mérito do recurso era, até pouco tempo, exclusiva dos órgãos colegiados do tribunal $^{7}$ e não de seus membros isoladamente. No passado, o direito pátrio conferia ao relator atribuições relacionadas com o processamento do recurso $^{8}$, reservando-se o julgamento ao órgão colegiado 9 .

Ocorre que, o desmedido aumento do número de demandas no Brasil, decorrente de uma multiplicidade de causas que não cabe aqui analisar, acarretou o aumento do número de recursos e a obstrução das pautas dos tribunais. Passou a ser necessário, então, buscar-se formas mais expeditas para a solução dos conflitos.

\footnotetext{
${ }^{4}$ MIRANDA, Pontes de. Comentários ao Código de Processo Civil. 3. Ed. Atual por Sérgio Bermudes. Rio de Janeiro: Forense, 1999, t. 7, p.11.

${ }^{5}$ Segundo aduz Araújo Cintra, o jurista Roger Perrot constatou, já em 1971, que a colegialidade estava em "declínio na França, especialmente em razão de preocupações com a aceleração dos processos" CINTRA, Araújo, apud RODRIGUES, Walter Piva. O princípio da colegialidade das decisões nos tribunais. Revista Dialética de Direito Processual, São Paulo, n.1, abr. 2003, p. 177.

${ }^{6}$ CARNEIRO, Athos Gusmão. Poderes do relator e agravo interno: art. 557, 544 e 545 do CPC. Revista de Processo, São Paulo, v.25, n.100, out./dez. 2000, p. 9. O autor lembra que em nosso país, o primeiro grau de jurisdição cabe a juízo singular em matéria cível, mas que ha previsão de julgamento colegiado no primeiro grau de Justiça Militar e no Tribunal do Júri.

${ }^{7}$ Dependendo da natureza do recurso ou da ação originária, as normas relativas à organização judiciaria impõe que o julgamento, quando colegiado, ficará a cargo das Câmaras ou Turmas (a denominação "turma" é, em geral, utilizada nos tribunais superiores e nos tribunais federais) ou de colegiados mais numerosos, como as Seções, as Câmaras Reunidas, os Grupos, o Plenário. (Idem)

${ }^{8}$ VICARI, Marcio Luiz Fogaça. Antecipação da tutela recursal e competência do relator. Revista Forense, Rio de Janeiro: Forense, vol. 353, jan./fev./2001, p. 215.

${ }^{9}$ MOREIRA, José Carlos Barbosa. Reformas processuais e poderes do juiz. Revista de Direito do Tribunal de Justiça do Estado do Rio de Janeiro, Rio de Janeiro, n.56, jul./set. 2003, p. 22.
} 
Uma das soluções encontradas foi a opção pelo julgamento singular. As recentes alterações introduzidas no sistema recursal civil brasileiro ampliaram significativamente os poderes do relator.

A primeira modificação, no que toca à colegialidade do julgamento dos recursos, foi introduzida pela Lei $n^{\circ} 9.139$, de 30 de novembro de 1995, que atribuiu ao relator competência para julgar monocraticamente o recurso manifestamente inadmissível, improcedente, prejudicado ou baseado em tese contraria a súmula do respectivo tribunal ou de tribunal superior, "como forma de se obter o mais rápido desfecho do procedimento deflagrado na instância revisora" $"$.

Referida competência foi ampliada por meio da Lei $\mathrm{n}^{\circ} 9.756$, de 17 de dezembro de 1998, que autorizou o relator a julgar recurso cuja tese contrarie jurisprudência dominante. Também por força da Lei $\mathrm{n}^{\circ} 9.756 / 98$, o relator foi autorizado a dar provimento ao recurso, singularmente, quando a decisão recorrida for contrária à súmula ou à jurisprudência dominante de tribunal superior, fincando "os marcos para uma releitura da regra do duplo grau de jurisdição cujo enunciado deverá passar a espelhar essa nova realidade"11.

Flagrante, pois, a tendência de mitigação do princípio que se convencionou rotular de “colegialidade das decisões" 12 , com a ampliação dos poderes dos relatores dos recursos ${ }^{13}$, a cujas decisões são concedidas a mesma eficácia e amplitude de que se revestiria a decisão colegiada $^{14} 15$.

\footnotetext{
${ }^{10}$ FERNANDES, Sérgio Ricardo de Arruda. A influência da jurisprudência dos tribunais no julgamento realizado na instância revisora. Revista de Direito do Tribunal de Justiça do Estado do Rio de Janeiro, Rio de Janeiro, n.67, p.60-9, abr./maio. 2006, p. 60.

${ }^{11}$ RODRIGUES, Walter Piva, op. cit., p. 177.

${ }^{12}$ Idem.

${ }^{13}$ NUNES, Dierle José Coelho. Colegialidade das decisões dos tribunais - sua visualização como princípio constitucional e do cabimento de interposição de agravo interno de todas as decisões monocráticas do relator. Revista IOB de Direito Civil e Processual Civil, Porto Alegre, v.9, n.50, nov./dez. 2007, p. 52.

${ }^{14}$ DANTAS, Ana Carolina de Araújo. Embargos declaratórios: da possibilidade de interposição em face de decisão monocrático do relator proferida com fulcro no artigo 557 do CPC. IOB - Repertório de Jurisprudência: Civil, Processual, Penal e Comercial, São Paulo, v.3, n.8, abr. 2011, p. 307.

${ }^{15}$ Como ressaltou Milton Luiz Pereira, "na afluência dessas anotações, mesmo assegurada a intervenção do colegiado (art. $545, \S 1^{\circ}$, e art. 557, CPC), pela viseira do sistema, e valorizados os precedentes, quanto ao Recurso Especial esta inequívoco que o relator julga. E, julgando, constitui pronunciamento com a mesma força cognitiva e dispositiva do julgado concretizado pelo colegiado. De tal sorte, no âmbito recursal, pelo alargamento
} 
Conforme magistério de Barbosa Moreira "o julgamento monocrático, antes característico, entre nós, do primeiro grau de jurisdição, vai-se impondo também nos superiores, em detrimento da colegialidade"16. No mesmo sentido se posiciona Adroaldo Furtado Fabrício: "a evolução recente da legislação processual civil brasileira caminha decididamente para uma progressiva relativização do principio da colegialidade no julgamento dos recursos, mediante ampliação dos poderes do relator, do que dá exemplo particularmente atual e notável o disposto na Lei 9.756/98,"17.

Eduardo J. Couture já alertara que: "La tendencia de nuestro tempo es la de aumentar los poderes del juez y diminuir el numero de recursos; es el triunfo de una justicia pronta y firme sobre la necesidad de una justicia bueno pero lenta" ${ }^{\text {.18 }}$. Com a ampliação dos poderes do relator, busca-se reduzir a duração dos processos e "desobstruir a pauta dos tribunais ao dar preferência a recursos que realmente reclamam a apreciação do colegiado"19

Bem salientou Dinamarco, “a crescente opção pela singularidade do julgamento em diversas situações representa uma legítima tentativa de inovar sistematicamente na luta contra a lentidão do julgamento nos tribunais. Sabe-se que o aumento do número de juízes não resolve o problema, como já não resolveu no passado remoto e próximo. É preciso inovar sistematicamente. O que fez a reforma e o que agora vem a fazer a reforma de 1998 representa uma escalada que vem da colegialidade quase absoluta e aponta para a singularização dos

da influencia dos precedentes, a decisão do relator tem a equivalência do aresto edificado pelo órgão fracionário competente. Em verdade, outra vez pensando em Eduardo Couture, as alterações cultuam a presteza nos autos processuais: "o tempo no processamento é mais que ouro, é justiça". (Embargos de divergência contra decisão lavrada por relator. Revista Forense, Rio de Janeiro, v.99, n.366, mar./abr. 2003, p. 377/378)

${ }^{16}$ BARBOSA MOREIRA, José Carlos. Algumas Inovações da Lei 9.756 em Matéria de Recursos Civis. Revista Forense, v. 346, abr/jun/1999, p. 96.

${ }^{17}$ FABRICIO, Adroaldo Furtado, apud CARNEIRO, Athos Gusmão. Poderes do relator e agravo interno: art. 557, 544 e 545 do CPC. Revista de Processo, São Paulo, v.25, n.100, out./dez. 2000, p. 11

${ }^{18}$ COUTURE, Eduardo J. Fundamentos del Derecho Procesal Civil. $3^{\mathrm{a}}$ ed., Buenos Aires: Ed. Depalma, 1985, p. 349.

${ }^{19}$ STJ, AgRg n ${ }^{\circ}$ 740.396-RJ, Rel. Min. Luiz Fux, j. 3.8.2006. 
julgados nos tribunais, restrita a casos onde se prevê que os órgãos colegiados julgariam segundo critérios objetivos e temperada pela admissibilidade de agravo dirigido a eles. $(. . .)^{20 \text {,. }}$

Ocorre que nem sempre são claros os parâmetros que o legislador fornece para indicar os limites dos poderes atribuídos aos relatores no direito contemporâneo.

A partir da exegese da legislação aplicável e do exame detido de aspectos doutrinários e práticos atinentes à matéria, pretendemos fazer uma análise minuciosa do aumento dos poderes do relator no julgamento dos recursos e um estudo aprofundado do artigo 557 do Código de Processo Civil.

Para tanto, tendo em vista que a análise que se pretende necessariamente pressupõe uma adequada delimitação e caracterização do objeto sob exame, dedicaremos a primeira parte do presente trabalho ao exame do duplo grau de jurisdição, seu conceito e seus fundamentos.

Na segunda parte deste trabalho serão abordadas a opção originária pelo julgamento monocrático em primeira instância e pelo juízo colegiado em segunda no Brasil e a crescente tendência de se mitigar a colegialidade. Neste tópico de cunho introdutório, procederemos a uma comparação do tratamento da questão da colegialidade dos julgamentos tal como feita no direito alienígena, especialmente no que diz respeito ao modelo europeu.

Em seguida, verificaremos o contexto em que foram ampliados os poderes do relator no julgamento dos recursos. Parece-nos ser de fundamental importância que sejam abordadas as razões que levaram o reformador a mitigar a opção pelo julgamento colegiado e aumentar os poderes do relator e as hipóteses de julgamento monocrático dos recursos, entre elas, a busca por simplificação dos procedimentos, a constante preocupação com a celeridade e a efetividade, a necessidade de diminuição do volume excessivo de recursos nos tribunais, o

\footnotetext{
${ }^{20}$ DINAMARCO, Candido Rangel. O relator, a jurisprudência e os recursos. In: WAMBIER, Teresa Arruda Alvim (coord.); NERY JUNIOR, Nelson (coord.). Aspectos polêmicos e atuais dos recursos cíveis de acordo com a lei 9.756/98. São Paulo: Revista dos Tribunais, 1999. p.130.
} 
surgimento de processos repetitivos e de massa e a busca pela valorização dos precedentes jurisprudenciais.

Passaremos então à análise histórica da evolução da atividade individual do relator, para que possamos compreender o estágio atual dos seus poderes. Primeiramente, verificaremos quais as atribuições dos relatores; traçado esse panorama, abordaremos as disposições legais vigentes sobre o tema e seguiremos com uma apresentação do histórico das alterações legislativas promovidas na redação do artigo 557 do Código de Processo Civil. Por fim, apontaremos o tratamento que os responsáveis pelo "novo" Código de Processo Civil pretendem dar à questão.

Ainda neste tópico abordaremos o debate doutrinário e jurisprudencial de se a possibilidade do relator julgar monocraticamente os recursos é inconstitucional e/ou representa ofensa ao duplo grau de jurisdição.

Feitas tais considerações, chegaremos ao ponto central de nosso estudo quando da análise do artigo 557 do Código de Processo Civil. O primeiro passo consiste em abordar a competência do relator (se age com função delegada do órgão colegiado), o alcance da atividade do relator, se esse julgamento monocrático é poder ou dever do relator e a necessidade de fundamentação da decisão monocrática.

Em seguida, passaremos ao exame das deficiências da redação do artigo 557 do Código de Processo Civil e do sentido das expressões "manifestamente", "manifesto" e "negar seguimento". Após, o estudo concentrar-se-á nas hipóteses previstas na norma para julgamento monocrático do recurso: (i) os recursos inadmissíveis, prejudicados e improcedentes; (ii) a contrariedade entre a tese recursal e súmula; (iii) a contrariedade entre a tese recursal e a jurisprudência dominante; e (iv) a hipótese de provimento do recurso.

No capítulo seguinte, serão esquadrinhados os meios processuais aptos a impugnar a decisão do relator. Primeiramente, a impugnação prevista no artigo 557 do Código - a natureza jurídica deste ato processual, seu procedimento, a possibilidade do juízo de retratação, os 
efeitos do recurso, as variantes possíveis do seu julgamento pelo órgão colegiado e algumas questões polêmicas, como a inclusão em pauta para julgamento e a possibilidade (ou não) de se conceder ao recorrido a oportunidade de oferecer resposta. Depois, julgamos conveniente analisar, ainda que de forma superficial, as alternativas de meios de impugnação, quais sejam, o mandado de segurança, a reclamação e a ação rescisória.

No capítulo final, exploraremos algumas questões polêmicas no que toca ao julgamento unipessoal dos recursos, tais como a possibilidade de aplicação concomitante dos artigos 515, $\$ 3^{\circ}$-A e 285-A do Código de Processo Civil, o julgamento de agravo retido, o cabimento dos embargos de declaração, de divergência e infringentes opostos e o momento de apreciação da existência de repercussão geral da questão constitucional (no caso de recurso extraordinário).

Finalmente, sem prejuízo das ilações trazidas no corpo do trabalho, serão deduzidas conclusões de forma articulada.

Toda nossa análise estará amparada em uma ampla contextualização histórica e social do tema, que buscará descrever os principais marcos legislativos e doutrinários relacionados à matéria possibilitando, destarte, uma melhor compreensão da atual conformação da disciplina jurídica dispensada ao julgamento monocrático dos recursos. Ademais, traremos à colação alguns julgados, cuja análise crítica terá o condão de iluminar com a experiência prática os aspectos doutrinários mais relevantes desenvolvidos ao longo do trabalho dissertativo. 


\section{CAPÍTULO 1 - O DUPLO GRAU DE JURISDIÇÃO}

\section{Conceito de duplo grau de jurisdição}

A atividade jurídica exercida pelo Estado, compreendidas legislação e jurisdição, tem por fim precípuo a segurança nas relações jurídicas, que constitui poderoso fator de pacificação social. Ao Estado, norteado pelo princípio do interest republicae ut sit finis litium, interessa que as controvérsias sejam solucionadas. Para dirimir os conflitos de interesse, a Constituição Federal de $1988^{21}$ garante o direito de acesso à justiça (ou garantias de ação e defesa), sendo que toda ameaça ou lesão a direito poderá ser submetida à apreciação do Poder Judiciário $^{22}$.

O processo não é apenas um instrumento técnico, mas sobretudo ético, influenciado por fatores históricos, sociológicos e políticos, e deve servir como meio de acesso à ordem jurídica justa. Seu ato final está consubstanciado na sentença, através da qual o juiz define a lide aplicando o direito ao caso concreto.

A fim de assegurar a justiça das decisões o ordenamento jurídico consagrou o duplo grau de jurisdição, disciplinando um sistema recursal que disponibiliza instrumentos processuais para revisão das decisões dos órgãos do poder judiciário em decorrência de sua eventual incorreção ou simplesmente para atender à inconformidade da parte vencida diante de um julgamento que lhe é desfavorável.

A ideia de duplo grau de jurisdição está intimamente ligada à de recurso, que, para Cândido Rangel Dinamarco, é "um ato de inconformismo, mediante o qual a parte pede nova decisão, diferente daquela que lhe desagrada. (...) Recorre-se da decisão que acolhe ou rejeita alguma pretensão no curso do processo sem definir a causa (decisões interlocutórias), recorrese do ato judicial que define a causa julgando-lhe o mérito ou não (sentenças), recorre-se de

21 “CF/88 - Art. $5^{\circ}$. (...) XXXV - a lei não excluirá da apreciação do Poder Judiciário lesão ou ameaça a direito".

${ }^{22}$ O texto do diploma de 1988 suprimiu a referência a direitos individuais (CINTRA, Antonio Carlos de Araújo, GRINOVER, Ada Pellegrini e DINAMARCO, Cândido Rangel, Teoria Geral do Processo, $19^{\mathrm{a}}$ ed., São Paulo, Malheiros Editores, 2003, p. 81). 
decisões tomadas pelos tribunais (acórdãos)"23. Dinamarco lembra, ainda, as lições de Liebman, para quem "está implícita no conceito de recurso a ideia de uma oposição, de um ataque - recorrer de uma sentença significa denunciá-la como errada e pedir uma nova sentença que remova o dano injusto causado por ela" ${ }^{24}$.

Ada Pellegrini Grinover define recurso como "meio voluntário de impugnação de decisões, utilizado antes da preclusão e na mesma relação jurídica processual, apto a propiciar a reforma, a invalidação, o esclarecimento ou a integração da decisão" 25 e Ovídio Araújo Baptista da Silva como o "procedimento através do qual a parte, ou quem esteja legitimado a intervir na causa, provoca o reexame das decisões judiciais, a fim de que elas sejam invalidadas ou reformadas pelo próprio magistrado que as proferiu, ou por algum órgão de jurisdição superior". ${ }^{26}$ Barbosa Moreira, por sua vez, define recurso como "o remédio voluntário idôneo a ensejar, dentro do mesmo processo, a reforma, a invalidação, o esclarecimento ou a integração da decisão judicial que se impugna"27 28.

É necessário traçar algumas anotações a respeito do conceito de recurso: (i) o recurso é remédio voluntário, razão pela qual o reexame necessário não é recurso propriamente dito; (ii) o recurso impede a preclusão temporal ${ }^{29}$ e neste aspecto diferencia-se das ações de

\footnotetext{
${ }^{23}$ DINAMARCO, Cândido Rangel. Nova Era do Processo Civil. $3^{a}$ ed., São Paulo: Malheiros, 2009, p.116/117. Prossegue o autor: "É conatural ao conceito de recurso, no direito brasileiro, o seu cabimento no mesmo processo, mesma relação processual, em que houver sido proferida a decisão impugnada".

${ }^{24}$ Idem, p. 116.

${ }^{25}$ GRINOVER, Ada Pellegrini. Um enfoque constitucional da teoria geral dos recursos in Revista Jurídica do Rio Grande do Sul, Porto Alegre, vol. 42, nº 198, abr./1994, p. 45

${ }^{26}$ SILVA, Ovídio Araújo Baptista da. Teoria geral dos recursos cíveis. In GOMES, Fabio Luiz; SILVA, Ovídio Araújo Baptista da. Teoria geral do processo civil, São Paulo: Revista dos Tribunais, 2010, p.277.

${ }^{27}$ BARBOSA MOREIRA, José Carlos apud. SILVA, Ovídio Araújo Baptista da. Op. Cit., p. 277.

${ }^{28}$ A apelação é o recurso por excelência; além de ser o remédio mais antigo é também o mais utilizado, conforme ensinamento de Enrico Redenti: "l`appello è un mezzo di impugnazione contro le sentenze di primo grado ed è senza dubbio quello di più largo uso perché... bom à tout faire") (Diritto processuale civile. $4^{\mathrm{a}}$ ed., Milano: Giuffrè, 1997, v. 2, p.443).

29 "No direito processual brasileiro, toda interposição recursal tem o efeito direto e imediato de prevenir a preclusão temporal, a qual fatalmente ocorreria se recurso algum fosse interposto. Ao recorrer, e independentemente do resultado dos variados pronunciamentos judiciais sobre o recurso interposto - juízo de admissibilidade pelo órgão inferior ou pelo superior, provimento ou improvimento do recurso, provimento para reformar ou para anular a decisão recorrida - a parte evita que o ato judicial recorrido adquira desde logo a firmeza e imunidade a questionamentos futuros, ou seja, ela evita que, ao menos naquele momento, ocorra a preclusão. Esse efeito esta presente em todo e qualquer recurso e chega ao ponto de integrar o conceito desse remédio processual. (...) é tradicional em doutrina a afirmação de que a interposição recursal tem o efeito de impedir a preclusão, ou seja, de evitar que ela se consume. Insurge-se contra ela Nelson Nery Junior, sustentando
} 
impugnação, já que no recurso há o prosseguimento da relação processual existente, enquanto que o meio autônomo de impugnação representa o exercício de uma nova ação e, portanto, de uma nova relação jurídica processual $^{30}$; e (iii) o direito de recorrer é um direito postestativo processual. $^{31}$

A ideia de recurso vem sempre correlacionada com o princípio do duplo grau de jurisdição, segundo o qual uma mesma matéria deve ser decidida duas vezes, por dois órgãos $\operatorname{distintos}^{32}$.

A conceituação do princípio do duplo grau de jurisdição não é feita de forma expressa pelo direito material, cabendo, pois, à doutrina. E os conceitos variam de acordo com os elementos utilizados por cada doutrinador para definir o princípio.

Para Chiovenda, ele consiste em que "toda causa, salvo os casos expressamente excepcionados em lei, deve poder passar pela plena cognição de dois órgãos jurisdicionais sucessivamente" ${ }^{, 33}$; Pisani defende ser a existência de uma nova cognição das questões que tenham sido objeto de exame pelo juiz de primeiro grau, ao passo que para Comoglio, Ferre e Taruffo, pelo duplo grau "ogli controversia deve poter passare, salvo casi eccezionali, attraverso due gradi di esame da parte del giudice in fatto e diritto. Tuttavia la dottrina ha posto bem in luce come questa regola non esiga affatto che deve poter <passare> attraverso il duplice grado di giudizio". ${ }^{34}$ Para Edoardo Ricci ${ }^{35}$, "il doppio gradi di giurisdizione può essere sinteticamente definito come quel modello di disciplina giuridica, che per ogni

que as interposições recursais têm somente o efeito de adiar ou retardar a preclusão, não o de impedí-la". (DINAMARCO, Cândido Rangel. Nova Era ..., Op. cit., p.119)

${ }^{30}$ GRINOVER, Ada Pellegrini.. Op. Cit., p. 44.

31 DIDIER Jr., Fredie, CUNHA, Leonardo José Carneiro da. Curso de Direito Processual Civil - Meios de Impugnação às decisões judiciais e Processo nos Tribunais. Salvador: JusPodivm, 2010, p. 19/20.

32 WAMBIER, Luiz Rodrigues. Teoria geral dos recursos. Revista de Processo, vol. 164, out./2008, p. 339. E, conforme pondera Dalmo de Abreu Dallari, "a definição da organização básica do Poder Judiciário brasileiro subordina-se, como um dos princípios gerais, à necessidade de assegurar a possibilidade de interferência de, pelo menos, dois graus de jurisdição para solução definitiva dos conflitos" (O poder dos juízes. São Paulo: Saraiva, 1996, p. 102).

${ }^{33}$ CHIOVENDA, apud DINAMARCO, Cândido Rangel. Nova Era ... Op. cit., p.167/168.

${ }^{34}$ COMOGLIO, Luigi Paolo; FERRI, Conrado; TARUFFO, Michele. Lezione sul processo civile. Bologna: Il Mulino, 1995, p. 678.

${ }^{35}$ RICCI, Edoardo F.. Doppio grado di giurisdizione (principio del). Enciclopedia Giuridica, v. 12, Rivista di Diritto Processuale XXXIII, 1978, pp. 59/85. 
controvérsia suscettibile di esame sul merito consente due successive statuizioni sul diritto dedotto nel processo, ad opera di due giudici diversi, la seconda delle quali destinata a prevalere sulla prima (...)"

O conceito também não é uniforme na doutrina nacional. Para Theodoro Júnior, o princípio do duplo grau de jurisdição é a possibilidade de se submeter a lide a exames sucessivos, por juízes diferentes ${ }^{36}$; para Araújo Cintra, Ada Pellegrini Grinover e Candido Rangel Dinamarco, é a possibilidade de revisão, por via de recurso, das causas já julgadas pelo juiz de primeiro grau (ou primeira instância) ${ }^{37}$; para Nelson Nery Junior, é a possibilidade de a sentença definitiva ser reapreciada por órgão de jurisdição normalmente de hierarquia superior à daquele que a proferiu ${ }^{38}$. Wambier ${ }^{39}$ adota o conceito de duplo juízo de mérito por dois órgãos diferentes; Oreste Laspro entende como sistema do duplo grau aquele em "em que, para cada demanda, existe a possibilidade de duas decisões validas e completas no mesmo processo, emanadas por juízes diferentes, prevalecendo sempre a segunda em relação à primeira" ${ }^{40}$; e para José Carlos Barbosa Moreira, não há definição universal válida do princípio do duplo grau, de modo que cabe ao intérprete extrair os dados necessários à sua caracterização do ordenamento sob análise ${ }^{41}$.

Consideramos necessárias algumas observações. A despeito de a expressão "duplo grau de jurisdição" ser de uso corrente e consagrado, há diversas reparações feitas pela doutrina quanto ao apuro técnico.

A primeira delas diz respeito ao fato de que o termo "duplo grau de jurisdição" parece nos remeter a uma duplicidade de jurisdição. Ocorre que a jurisdição constitui projeção da

\footnotetext{
${ }^{36}$ THEODORO JÚNIOR, Humberto. Curso de Direito Processual Civil - Teoria Geral do direito processual civil e processo de conhecimento, Rio de Janeiro: Forense, 2009, p. 562.

${ }^{37}$ ARAÚJO CINTRA, Antonio Carlos; GRINOVER, Ada Pellegrini; DINAMARCO, Cândido Rangel. Teoria geral do processo. São Paulo: Malheiros, 2004, p. 74.

${ }^{38}$ NERY JÚNIOR, Nelson. Princípios do processo civil na Constituição Federal. São Paulo: Revista dos Tribunais, 2004, p. 44.

${ }^{39}$ WAMBIER, Luiz Rodrigues. Op. Cit., p. 339.

${ }^{40}$ DINAMARCO, Cândido Rangel. Nova Era ..., Op. cit., p. 167/168.

${ }^{41}$ BARBOSA MOREIRA, José Carlos. Comentários ao Código de Processo Civil, v. 5, $11^{\text {a }}$ ed., Rio de Janeiro: Forense, 2003, p. 238/239.
} 
soberania e é, portanto, una, não comportando divisões ${ }^{42}$. O termo, na verdade, não faz referência à duplicidade da jurisdição, que conduziria a admissão da existência de várias soberanias, mas à possibilidade de exame das decisões por dois órgãos jurisdicionais distintos, sendo mais apropriado falar-se de um duplo grau de cognição ou de julgamento das lides ${ }^{43}$.

Ademais, o termo "grau" remete à ideia de hierarquia ${ }^{44}$ e não é pacífica na doutrina a necessidade de superposição hierárquica dos juízos a quo e ad quem. ${ }^{45}$ Para a Professora Ada Pellegrini Grinover, o princípio do duplo grau não exige o julgamento por órgão hierarquicamente superior, mas a revisão da decisão por órgão diverso do que julgou em primeiro grau. Nelson Nery Junior comunga da ideia de que não é necessário, para que esteja presente o duplo grau de jurisdição, que o segundo julgamento seja conferido a órgão de categoria hierárquica superior à do que realizou o primeiro exame ${ }^{46}$.

Por fim, é comum confundirem-se os conceitos de duplo grau de jurisdição e direito de recorrer $^{47}$. Contudo, no direito brasileiro, embora haja o direito de recorrer, não necessariamente há o duplo grau de jurisdição ${ }^{48} \mathrm{e}$, em outras hipóteses, embora haja o duplo grau de jurisdição, não há recurso concomitante ${ }^{49}$.

\footnotetext{
${ }^{42}$ ARAÚJO CINTRA, Antonio Carlos; GRINOVER, Ada Pellegrini; DINAMARCO, Cândido Rangel. Op. Cit.

${ }^{43}$ TAVARES, André Ramos. Análise do duplo grau de jurisdição como princípio constitucional. Revista de Direito Constitucional e Internacional, vol. 30, jan./mar./2000, p. 178.

${ }^{44}$ TAVARES, André Ramos. Op. Cit., p. 178.

${ }^{45}$ Nas palavras de Ada Pellegrini Grinover: "Chama-se de jurisdição inferior aquela exercida pelos juízes que conhecem do processo desde o seu inicio (competência originária). E denomina-se jurisdição superior a exercida pelos órgãos a que cabem os recursos contra as decisões proferidas pelos juízes inferiores. Essa terminologia, que é corrente, não significa, porém, uma relação de subordinação entre os juízes. Assim, deve-se entender por jurisdição superior e inferior não uma competência de mando, mas apenas uma competência de derrogação, no sentido de a primeira poder reapreciar, em segundo grau, a causa já decidida, substituindo com sua decisão a de primeiro grau.”. (GRINOVER, Ada Pellegrini. Op. Cit., p. 43).

${ }^{46}$ NERY JUNIOR, Nelson, apud LINS, Rodrigo Martiniano Ayres. A relativização do princípio do duplo grau cognitivo no processo civil brasileiro como instrumento de efetividade da tutela jurisdicional. Revista Forense, vol. 385, maio/jun./2006, p 175/176.

${ }^{47}$ A recursividade tem maior extensão que o duplo grau de jurisdição por abranger todas as formas de recurso.

${ }^{48}$ Como no caso dos embargos de declaração.

${ }^{49}$ TAVARES, André Ramos. Op. Cit., p. 178.
} 


\section{A expressão "duplo grau de jurisdição"}

A despeito de a expressão "duplo grau de jurisdição" ser de uso corrente e consagrado, há diversas reparações feitas pela doutrina quanto ao apuro técnico.

A primeira delas diz respeito ao fato de que o termo "duplo grau de jurisdição" parece nos remeter a uma duplicidade de jurisdição. Ocorre que a jurisdição constitui projeção da soberania e é, portanto, una, não comportando divisões ${ }^{50}$. O termo, na verdade, não faz referência à duplicidade da jurisdição, que conduziria a admissão da existência de várias soberanias, mas à possibilidade de exame das decisões por dois órgãos jurisdicionais distintos, sendo mais apropriado falar-se em um duplo grau de cognição ou de julgamento das lides ${ }^{51}$.

Ademais, o termo "grau" remete à ideia de hierarquia ${ }^{52}$ e não é pacífica na doutrina a necessidade de superposição hierárquica dos juízos a quo e ad quem. Nas palavras de Ada Pellegrini Grinover" ${ }^{53}$ : "Chama-se de jurisdição inferior aquela exercida pelos juízes que conhecem do processo desde o seu início (competência originária). E denomina-se jurisdição superior a exercida pelos órgãos a que cabem os recursos contra as decisões proferidas pelos juízes inferiores. Essa terminologia, que é corrente, não significa, porém, uma relação de subordinação entre os juízes. Assim, deve-se entender por jurisdição superior e inferior não uma competência de mando, mas apenas uma competência de derrogação, no sentido de a primeira poder reapreciar, em segundo grau, a causa já decidida, substituindo com sua decisão a de primeiro grau.".

Para a Professora Ada, portanto, o princípio do duplo grau não exige o julgamento por órgão hierarquicamente superior, mas a revisão da decisão por órgão diverso do que julgou em primeiro grau. Nelson Nery Junior comunga da ideia de que não é necessário, para que esteja

\footnotetext{
${ }^{50}$ ARAÚJO CINTRA, Antonio Carlos; GRINOVER, Ada Pellegrini; DINAMARCO, Cândido Rangel. Op. Cit.

51 TAVARES, André Ramos. Análise do duplo grau de jurisdição como princípio constitucional, in Revista de Direito Constitucional e Internacional, vol. 30, jan./mar./2000, p. 178.

${ }^{52}$ TAVARES, André Ramos. Op. Cit., p. 178.

${ }^{53}$ GRINOVER, Ada Pellegrini.. Op. Cit., p. 43.
} 
presente o duplo grau de jurisdição, que o segundo julgamento seja conferido a órgão de categoria hierárquica superior à do que realizou o primeiro exame ${ }^{54}$.

Por fim, é comum confundirem-se os conceitos de duplo grau de jurisdição e direito de recorrer $^{55}$. Contudo, no direito brasileiro, embora haja o direito de recorrer, não necessariamente há o duplo grau de jurisdição ${ }^{56} \mathrm{e}$, em outras hipóteses, embora haja o duplo grau de jurisdição, não há recurso concomitante ${ }^{57}$.

\section{Fundamentos do duplo grau de jurisdição}

O primeiro deles é o inconformismo da parte recorrida. É da natureza do ser humano não se contentar com uma primeira censura a ele imposta ou um julgamento que lhe seja contrário $^{58}$, como bem coloca Nelson Nery Jr.: "nosso subjetivismo nos coloca naturalmente contra a decisão desfavorável, de sorte que o sentimento psicológico do ser humano faz com que tenha reação imediata à sentença desfavorável, impelindo-o a pretender, no mínimo, novo julgamento sobre a mesma questão" 59 .

Tem-se dito que a ideia de recurso responde a esta necessidade psicológica do ser humano quando se depara com uma situação desfavorável ao seu interesse ${ }^{60}$. E, além da chance de se obter uma nova decisão favorável a seu interesse, o duplo grau representa para as partes uma maior segurança por saberem que o juiz da causa, por ter sua decisão sujeita a revisão, agirá de forma responsável e fundamentará melhor seu julgamento ${ }^{61}$.

\footnotetext{
${ }^{54}$ LINS, Rodrigo Martiniano Ayres. A relativização do princípio do duplo grau cognitivo no processo civil brasileiro como instrumento de efetividade da tutela jurisdicional, In Revista Forense, vol. 385, maio/jun./2006, p $175 / 176$.

${ }_{55}^{5}$ A recursividade tem maior extensão que o duplo grau de jurisdição por abranger todas as formas de recurso.

${ }^{56}$ Como no caso dos embargos de declaração.

${ }^{57}$ TAVARES, André Ramos. Op. Cit., p. 178.

${ }^{58}$ Idem, p. 177.

${ }^{59}$ NERY JUNIOR, Nelson, apud NOGUEIRA, Mauricio José. Duplo grau de jurisdição: aspectos constitucionais e reflexos processuais. In FUX, Luiz; NERY JUNIOR, Nelson; WAMBIER, Teresa Arruda Alvim. Processo e constituição: estudos em homenagem ao professor José Carlos Barbosa Moreira. São Paulo: Revista dos Tribunais, 2006. p. 542.

${ }^{60}$ NOGUEIRA, Mauricio José. Op. Cit., p. 542.

${ }^{61}$ SILVA, Ovídio Araújo Baptista da. Op. Cit., p. 277.
} 
O princípio do duplo grau de jurisdição tem, ainda, um fundamento de natureza política, qual seja, o de que nenhum ato estatal deve ficar livre de controle, sendo que a revisão das decisões judiciárias é postulado do Estado de direito para evitar possível abuso do $\operatorname{poder}^{62}$.

O controle divide-se em dois planos, ambos ligados à estrutura do Estado de direito; em um primeiro plano a sociedade, "representada" em cada processo pelas partes, exerce o controle da atividade estatal por meio do manejo dos recursos e em um segundo plano, órgão jurisdicional diverso daquele que proferiu a decisão em primeiro grau realiza um controle interno objetivando conferir a legalidade e a justiça da decisão. ${ }^{63}$

\section{Argumentos favoráveis à adoção do duplo grau de jurisdição}

Os elementos favoráveis à ampla incidência do princípio do duplo grau de jurisdição são: (i) o benefício psicológico dado às partes, por aplacar a reação de inconformismo que é natural do ser humano; (ii) a maior probabilidade de acerto de um segundo julgamento, principalmente se feito por um órgão colegiado composto de juízes mais experientes; (iii) a possibilidade de erro do juiz de primeira instância; (iv) a necessidade de controle dos juízes de primeira instância; (v) o aprofundamento do exame da questão; e (vi) a uniformização da jurisprudência.

\subsection{Beneficio psicológico às partes}

O princípio do duplo grau de jurisdição, como visto, atende à natural inconformidade do vencido em relação à decisão contrária ${ }^{64}$. É sabido que a sentença, muitas vezes, em vez de promover a pacificação, acaba por acirrar o conflito. Assim, se os julgamentos ficassem confiados apenas ao primeiro grau, a litigiosidade seria contida ${ }^{65}$, permitindo a perpetuação

\footnotetext{
${ }^{62}$ GRINOVER, Ada Pellegrini.. Op. Cit., p. 40.

${ }^{63}$ MARCATO, Ana Cândida Menezes. O Princípio do Duplo Grau de Jurisdição e a Reforma do CPC. São Paulo: Ed. Atlas, 2006, p. 38/39.

${ }^{64}$. A professora Ada Pellegrini Grinover leciona que, além do benefício psicológico, é possível que a decisão seja realmente injusta ou incorreta, de forma que se deve possibilitar sua revisão pelo órgão ad quem. (Op. Cit., p. 39).

${ }^{65}$ Conforme expressão cunhada por Kazuo Watanabe.
} 
dos estados de insatisfação e desconfiança, provavelmente acrescidos de revoltas e $\operatorname{agravamentos}^{66}$. A possibilidade de reexame, por sua vez, oferece ao derrotado uma nova oportunidade de obtenção de um resultado favorável e o julgamento por um órgão colegiado e composto de juízes mais experientes, o que gera maior probabilidade de acerto da decisão.

\subsection{Maior experiência dos julgadores do órgão ad quem}

Em nosso país, regra geral, o reexame é feito por um órgão colegiado constituído em geral por magistrados de maior experiência e cultura ${ }^{67}$, de modo a conferir maior segurança às decisões judiciais. Diz-se que há maior probabilidade de acerto por o julgamento realizado por um grupo de juízes ${ }^{68}$ e por os juízes de segunda instância exercem suas funções há mais tempo, possuindo maior experiência de profissão e de vida.

Neste aspecto, são oportunos os ensinamentos de Vicente Greco Filho ${ }^{69}$ :“A existência de um sistema recursal adequado atende ao princípio da pluralidade dos graus de jurisdição e aos ideais de justiça. Como diz Chiovenda, basta que o juiz saiba que sua sentença pode ser reexaminada e modificada por um tribunal superior para que seja mais cuidadosa e mais justa. Os vários graus de jurisdição existem não apenas porque os superiores têm mais conhecimento ou sabedoria, pois, se assim fosse, as ações deveriam ser julgadas todas diretamente por eles, mas porque, em cada grau, o órgão jurisdicional vê o caso concreto de maneira própria: o primeiro, mais próximo ao fato, pode apreciar todos os seus pormenores, inclusive os fatores de difícil transcrição para o papel, por exemplo, a sinceridade de uma testemunha; o segundo grau, exatamente porque está mais distante dos fatos, pode ter uma visão mais adequada do contexto dos acontecimentos e de outros casos análogos, bem como aperfeiçoar, em termos gerais, a interpretação do direito. As legislações modernas que guardam afinidade cultural com a nossa, todas elas adotam o princípio da pluralidade de graus de jurisdição, procurando obter, como diz Moniz de Aragão, o máximo de acerto no mínimo de tempo”.

\footnotetext{
${ }^{66}$ DINAMARCO, Cândido Rangel. Instituições de direito processual civil, vol. 1, São Paulo: Malhieros, 2001 , p. $236 / 237$.

${ }^{67}$ GRINOVER, Ada Pellegrini.. Op. Cit., p. 39/40.

${ }^{68}$ Oportuno lembrar que nem sempre as decisões de segundo grau são colegiadas a teor dos art. 544 , $\S 3^{\circ}$ e 557 caput e $\S 1^{\circ}$-A do Código de Processo Civil.

${ }^{69}$ GRECO FILHO, Vicente. Direito processual civil brasileiro, vol. 2, São Paulo: Saraiva, 2003, p. 267.
} 


\subsection{Possibilidade de erro do juiz de primeira instância}

A possibilidade de erro do juiz de primeira instância funda-se na falibilidade humana. O juiz, como ser humano, não é imune ao cometimento de erros e a possibilidade de falha é ainda mais relevante se levarmos em consideração a importância dos atos decisórios.

Contudo, este argumento é objeto de severas críticas por parte da doutrina, mormente por se tratar de critério subjetivo e arbitrário e por não ter respaldo em qualquer estudo que demonstre a maior incidência de erros nas decisões prolatadas pelos juízos de primeiro grau do que pelos de segundo. Roberto Rosas, citado por André Ramos Tavares, afirma que: "O argumento não é suficiente para a instituição do duplo grau de jurisdição. Os erros podem ser cometidos em vários graus. Ao lado da perfeição é necessário dar-se celeridade e mobilidade ao processo, evitando-se a perpetuação de demandas, e desprestígio ou desinteresse pelas soluções afinal dadas. (...) Enfim, o desejo da justiça plena e perfeita é um ideal. Mas não é o reexame que impõe o selo da veracidade, da correção. Já Ulpiano observava que a instância superior reformava para pior em muitos casos (neque enim utique melius promitiat, qui novissimus setentiam laturus est, Dig. 49, 11 - L.I, de Appelationibus). Como acrescenta Alcides Mendonça de Lima, há no recurso uma finalidade eminentemente política, como meio de resguardar as liberdades individuais contra o arbítrio, o despotismo e as fraquezas dos juízes de primeira instância."70

\subsection{Controle das decisões dos juízes de primeira instância}

O controle das decisões dos juízes de primeira instância possui dois vieses: o controle psicológico e o controle externo dos atos dos magistrados. Para muitos, a mera possibilidade de a parte poder recorrer da decisão - e, portanto, desta ser revista por outro órgão jurisdicional - é suficiente para evitar abusos ou descaso do julgador $a$ quo ${ }^{71}$, que fica psicologicamente compelido a julgar melhor ${ }^{72}$. Os que se opõem à justificativa afirmam que o

\footnotetext{
${ }^{70}$ TAVARES, André Ramos. Op. Cit., p. 182.

${ }^{71}$ SHIMURA, Sérgio. Op. Cit., p. 604.

${ }^{72}$ GRINOVER, Ada Pellegrini.. Op. Cit., p. 39/40.
} 
controle psicológico que decorre da simples existência de tribunais superiores não é suficiente para induzir comportamento mais cuidadoso nos magistrados de primeiro grau, pois, embora não lhes agrade a ideia de reforma de suas decisões, possuem garantias da vitaliciedade e chances de ascender na carreira, seja por merecimento ou antiguidade ${ }^{73}$.

Além disso, como dito, outra vantagem propiciada pela aplicação do duplo grau de jurisdição seria o controle externo dos atos dos juízes ${ }^{74}$. O argumento reside na necessidade de fiscalização das atividades estatais, ainda mais quando se trata de atividade praticada pelo Judiciário, composto de membros que não são eleitos pela população ${ }^{75}$.

Para Denise Maria Weiss de Paula Machado e João Carlos Leal Júnior ${ }^{76}$, é improcedente a asserção de que a revisão das decisões do órgão a quo pelo ad quem seja fundamental para o controle das suas atividades, uma vez que "o recurso não configura reclamação contra o juiz inferior, mas 'expediente para passar de um a outro exame da causa' (...) os Tribunais, por meio das corregedorias, têm mecanismos próprios para inibir condutas ilícitas, que, por óbvio, não se confundem com decisões injustas"77.

\subsection{Maior exame da decisão}

O segundo julgamento possibilita o aprofundamento do exame da questão controvertida, não apenas por ser feito, via de regra, por um órgão colegiado composto por juízes mais experientes, mas também por haver apreciação mais objetiva e isenta da causa, dado que os magistrados estarão afastados do contato com as partes e, portanto, do calor dos debates travados em primeira instância.

\footnotetext{
${ }^{73}$ MARCATO, Ana C. Menezes. Op. Cit., p. 43.

${ }^{74} \mathrm{O}$ controle externo do Poder Judiciário é objeto de grande polêmica; afirmam seus opositores que o controle representa ameaça à autonomia e independência do Poder Judiciário e ao princípio da separação de poderes.

${ }^{75}$ A Reforma do Judiciário promovida pela Emenda Constitucional no 45/2004, com a consequente criação do Conselho Nacional de Justiça, possibilitou o controle externo do Poder Judiciário.

${ }^{76}$ MACHADO, Denise Maria Weiss de Paula; LEAL JÚNIOR, João Carlos., Op. Cit., p. 105.

${ }^{77}$ Os autores prosseguem “(...) E não se fundamente na assertiva de que é mais fácil corromper o juiz singular do que um colegiado, posto que, admissível o argumento, recomendar-se-ia a adoção generalizada de órgãos colegiados em primeiro grau. Demais disso, no processo civil brasileiro contemporâneo, tem-se outorgado verdadeiro feixe de poderes ao relator, bem como ao Presidente e Vice dos Tribunais, casos em que, como no juízo a quo, a decisão advirá de uma única pessoa". (p.106)
} 
Além disso, o órgão ad quem poderá acrescer o seu trabalho ao realizado pelo juízo de primeira instância e terá maior facilidade de identificar eventuais erros e imperfeições ${ }^{78}$. José Carlos Barbosa Moreira, citado por Ana Marcato ${ }^{79}$, afirma que "é dado da experiência comum que uma segunda reflexão acerca de qualquer problema frequentemente conduz a mais exata conclusão, já pela luz que projeta sobre ângulos até então ignorados, já pela oportunidade que abre para a reavaliação de argumentos a que no primeiro momento talvez não se tenha atribuído o justo peso" ${ }^{\natural 0}$.

\subsection{Uniformização da jurisprudência}

Por fim, o princípio do duplo grau de jurisdição favorece a uniformização da jurisprudência quanto a interpretação da legislação pátria, e evita a dispersão de julgados que fatalmente ocorreria se cada um dos juízos de primeiro grau decidisse em caráter definitivo ${ }^{81}$.

\section{Argumentos desfavoráveis à adoção do duplo grau de jurisdição}

Não se desconhecem, entretanto, os argumentos ponderáveis contrários ao duplo grau: (i) maior demora na solução do litígio; (ii) ausência dos benefícios decorrentes da oralidade, da imediação e da concentração dos atos processuais; (iii) inutilidade do acórdão que confirma uma sentença justa; (iv) possibilidade de o órgão ad quem substituir uma sentença justa por um acórdão injusto; (v) ausência de demonstração de que a decisão de segundo grau seja mais “certa” ou mais justa; e (vi) desprestígio do magistrado de primeira instância. ${ }^{82} 83$

\footnotetext{
${ }^{78}$ José Maria Rosa Tesheiner faz precisa observação, ao apontar que "Perceber-se um erro é mais fácil, depois de apontado. É também mais fácil corrigir os erros de outrem, do que os próprios".(Em Tempo de Reformas: $O$ Reexame de Decisões Judiciais, in Revista de Processo, v. 147, maio 2007, p. 155).

${ }^{79}$ MARCATO, Ana C. Menezes. Op. Cit., p. 45.

${ }^{80}$ Em sentido oposto, Denise Maria Weiss de Paula Machado e João Carlos Leal Júnior afirmam que "ainda que seja 'dado da experiência comum que uma segunda reflexão acerca de qualquer problema' frequentemente conduza a uma conclusão mais exata, é também cediço que "nada assegura, na pratica, a superioridade e a correção do segundo pronunciamento"' (Op. Cit. p. 105).

${ }^{81}$ MACHADO, Denise Maria Weiss de Paula; LEAL JÚNIOR, João Carlos., Op. Cit., p. 86/87.

${ }^{82}$ Às críticas usualmente invocadas pela doutrina, Ada Pellegrini Grinover acrescenta que "a decisão que reforma a recorrida é sempre nociva, por apontar uma divergência que da margem a duvidas quanto à correta aplicação do direito, produzindo incertezas nas relações jurídicas e desprestigiando o Poder Judiciário" (Op. Cit., p. 40). Sérgio Shimura lembra, ainda, que (i) se houvesse evidencias de que o tribunal julga melhor que o juiz de
} 


\subsection{Maior demora na solução do litígio}

A possibilidade de revisão das decisões judiciais, aliada aos inúmeros recursos interpostos por razões protelatórias, principalmente em nosso país, acarreta maior demora na solução do litígio ${ }^{84}$ que, além de causar prejuízos econômicos, implica denegação da justiça e ofensa ao devido processo legal.

A despeito de os recursos colaborarem para a maior duração dos processos, fato é que não são a única causa de morosidade da justiça; o duplo grau, caracterizado como a possibilidade de revisão total da decisão judicial, está relacionado com o recurso de apelação, e não com todos os inúmeros outros recursos existentes em nosso ordenamento. Além disso, é sabido que o Poder Público é responsável por grande número das demandas em nosso país, sendo que as sentenças a ele desfavoráveis estão sujeitas ao reexame necessário que, embora não constitua recurso propriamente dito, colabora para aumentar o número de causas sujeitas a novo julgamento. Por fim, "a existência de um segundo grau de jurisdição supõe que a sociedade esteja disposta a suportar o retardamento e o encarecimento daí decorrentes". ${ }^{85}$

\footnotetext{
primeiro grau, deveria se permitir a propositura da ação diretamente em segundo grau e (ii) "muitas vezes o recurso é movido por mero capricho da parte ou espírito de vindita ou de procrastinação do feito, alem de encerrar uma forma, elegante, de autorizar o advogado a cobrar mais pelos seus préstimos". (Op. Cit., p. 605). E José Maria Rosa Tesheiner afirma que há quem defenda que (i) se as partes pudessem escolher o juiz, não haveria necessidade de recurso, (ii) a reforma de uma sentença indica mau funcionamento do sistema judiciário, (iii) os recursos servem para a concentração de poder numa aristocracia judiciária e (iv) não há demonstração de que a decisão de segundo grau seja mais "certa" ou mais justa (Op. Cit., p. 154/156).

83 Ana Marcato analisa a posição de alguns doutrinadores italianos, diante das questões desfavoráveis à observância do duplo grau e à garantia ao recurso de apelação, e da preocupação com a duração razoável do processo: "Mauro Cappelletti, em seu Parecere Iconoclastico, concluiu que o sistema caminha para a necessidade de valorização do juiz de primeiro grau e a supressão dos juízos de impugnação. Edoardo Ricci retomou usa idéias e acrescentou algumas criticas: afirma que a defesa do duplo grau de jurisdição era feita sob o fundamento ideológico e político de garantia de Justiça, e no terreno jurídico-positivo, sob o argumento de que a segunda decisão deveria ser mais digna de credito e de maior confiança do que a primeira, já que proferida por um juiz superior; entretanto, com a crise que se instalou no terreno jurídico-positivo, ele sustenta ser licito indagar-se se a decisão de segundo grau não corre o risco de ser a menos digna de confiança das duas". (MARCATO, Ana C. Menezes. Op. Cit., p. 49/50).

${ }^{84}$ MACHADO, Denise Maria Weiss de Paula; LEAL JÚNIOR, João Carlos., Op. Cit., p. 107.

${ }^{85}$ TESHEINER, José Maria Rosa. Op. Cit., p. 154.
} 


\subsection{Ausência dos benefícios decorrentes da oralidade, da imediação e concentração dos atos processuais}

O juiz de primeira instância participa de forma efetiva no contraditório e na produção probatória em todos os seus aspectos, ao passo que os magistrados de $2^{\text {a }}$ instância não participam da colheita das provas e tampouco têm contato com as partes e com as testemunhas ${ }^{86}$; apenas leem os depoimentos das partes e as declarações das testemunhas. Para Ada Pellegrini Grinover ${ }^{87}$, “(...) nada garante que a decisão do tribunal seja melhor do que a do juiz de primeiro grau (...). Até porque é o juiz recorrido que teve, em geral, o contato imediato com as partes e as provas (princípios da imediação e da identidade física do juiz), tendo tido a oportunidade de melhor formar seu convencimento, enquanto o tribunal, via de regra, julga apenas com base nos documentos escritos existentes nos autos" ${ }^{\text {"88. }}$.

\subsection{Inutilidade do acórdão que confirma uma sentença justa e possibilidade de o órgão ad quem substituir uma sentença justa por um acórdão injusto}

As posições contrárias à adoção do duplo grau de jurisdição defendem que a decisão em grau de recurso, quando confirma a de primeiro grau, acarreta a prática de uma série de atos processuais inócuos e irrelevantes para a atividade jurisdicional, em afronta o princípio da economia processual. Isto porque a parte recorrente continuará insatisfeita com o julgamento, os custos processuais serão elevados e o desfecho do processo (que seria o mesmo sem o recurso) será retardado.

Por outro lado, a decisão recorrida que é mantida ${ }^{89}$ por órgão que goza de maior prestígio traz maior segurança para a parte vencedora e conforto para a parte vencida, que pôde utilizar-se de todos os meios processuais disponíveis para a busca da tutela jurisdicional que entendia ser-lhe devida.

\footnotetext{
${ }^{86}$ MACHADO, Denise Maria Weiss de Paula; LEAL JÚNIOR, João Carlos., Op. Cit., p. 103/105.

${ }^{87}$ GRINOVER, Ada Pellegrini.. Op. Cit., p. 40.

${ }^{88}$ Alessandro Pizzorusso alerta para o fato de que o decurso do tempo entre a interposição do recurso e seu o julgamento pode fazer com que as provas sejam corrompidas (como ocorre com a memória das testemunhas) e com que a valoração dos fatos fique restrita à leitura dos autos. MARCATO, Ana C. Menezes. Op. Cit., p. 45).

${ }^{89}$ Necessário ter em mente o efeito substitutivo dos acórdãos. A decisão não é mantida, nem confirmada; o julgamento o é.
} 
Além disso, é preciso considerar o universo das decisões de primeiro grau. Pior do que a confirmação de uma sentença justa é não haver recurso algum para a hipótese de sentença injusta. Mesmo porque como lembrado por, José Maria Rosa Tesheiner ${ }^{90}$, "pode-se admitir que ofende o direito a simples existência de recurso interposto de uma sentença justa, mas a justiça de uma decisão somente pode ser afirmada a posteriori, ou seja, depois de examinado o recurso".

Ao mesmo tempo em que existe a possibilidade de um acórdão proferido pelo segundo grau confirmar uma sentença justa, pode ocorrer de o órgão ad quem reformar uma sentença justa que estivesse em conformidade com o direito ${ }^{91}$. Isto porque, assim como os magistrados de primeiro grau, os de segunda instância também estão sujeitos à falibilidade humana, podendo se equivocar e também cometer erros e injustiças ${ }^{92}$.

\subsection{Desprestígio do magistrado de primeira instância}

O desprestígio do magistrado de primeira instância ocorre na medida em que, tendo-se em vista que o julgamento de segundo grau substitui o de primeiro, o juiz a quo atuaria como mero instrutor do processo, responsável por presidir a produção de provas e opinar quanto ao mérito da demanda, opinião esta a ser posteriormente confirmada ou não pelo segundo grau ${ }^{93}$.

Confinado a este papel de mero elaborador de pareceres, em que sua decisão atua como projeto da verdadeira decisão, proferida pelo órgão ad quem $^{94}$, o magistrado de primeiro grau inevitavelmente optaria por concentrar-se na quantidade de feitos julgados, negligenciando a qualidade de suas decisões, dado que um exame mais aprofundado e fundamentado demandaria mais tempo 9596

\footnotetext{
90 TESHEINER, José Maria Rosa. Op. Cit., p. 155.

91 Para Araken de Assis, a mera divergência entre as decisões é nociva, por expor divergência e afastar a confiança e o prestígio da via judiciária (Manual dos recursos, $2^{a}$ ed., São Paulo: Revista dos Tribunais, 2008 , p. 73/74).

92 MARCATO, Ana C. Menezes. Op. Cit., p. 49.

93 MARCATO, Ana C. Menezes. Op. Cit., p. 48.

${ }^{94}$ MACHADO, Denise Maria Weiss de Paula; LEAL JÚNIOR, João Carlos., Op. Cit., p. 103/105.

${ }^{95}$ MACHADO, Denise Maria Weiss de Paula; LEAL JÚNIOR, João Carlos., Op. Cit., p. 106.
} 
Contra tais argumentos, invoca-se a possibilidade de as partes optarem por não interpor recurso, conformando-se com o resultado que lhes é desfavorável, ou de o recurso eventualmente interposto ser desprovido, hipóteses em que não haveria nenhum desprestígio ao primeiro grau.

\section{Princípio ou garantia constitucional?}

No Brasil, a Constituição do Império de 1824 consagrava expressamente o duplo grau de jurisdição ao dispor, em seu art. $158^{97}$, que as causas poderiam ser reapreciadas sempre que a parte demonstrasse seu interesse, pelo chamado Tribunal da Relação ${ }^{98}$, de modo que ao legislador ordinário era vedado limitar os casos de cabimento de recursos ${ }^{99}$.

Contudo, as constituições seguintes deixaram de contemplar de maneira explícita o duplo grau de jurisdição. Surgem então as perguntas: o duplo grau é realmente um princípio constitucional? Representa ele uma garantia constitucional? ${ }^{100}$

Tem prevalecido o entendimento de que a atual Constituição Federal não elevou o duplo grau de jurisdição à categoria de direito fundamental, nem o assegura de modo absoluto e ilimitado ${ }^{101}$. Nelson Nery afirma que as Constituições que seguiram a de 1824 "limitaram-se a apenas mencionar a existência de tribunais, conferindo-lhes competência recursal. Implicitamente, portanto, havia previsão para a existência de recurso"102.

\footnotetext{
${ }^{96}$ Conforme notícia de Ana Marcato, na Itália, a discussão sobre a necessidade de restabelecimento da importância dos juízes de primeiro grau levou muitos doutrinadores a sugerir "a abolição da pluralidade de instâncias, unificando todos os julgadores em uma única instância (MARCATO, Ana C. Menezes. Op. Cit., p. 48).

97 "Para julgar as causas em segunda, e última instância haverá nas Províncias do Império as Relações, que forem necessárias para comodidade dos Povos.”

${ }^{98}$ No decorrer da história o Tribunal da Relação foi denominado de Tribunal de Apelação e, atualmente, de Tribunal de Justiça.

${ }^{99}$ LINS, Rodrigo Martiniano Ayres. Op. Cit., p. 174.

${ }^{100}$ MARCATO, Ana C. Menezes. Op. Cit., p. 27.

${ }^{101}$ SHIMURA, Sérgio. Reanálise do duplo grau de jurisdição obrigatório diante das garantias constitucionais. In FUX, Luiz; NERY JUNIOR, Nelson; WAMBIER, Teresa Arruda Alvim. Processo e constituição: estudos em homenagem ao professor José Carlos Barbosa Moreira. São Paulo: Revista dos Tribunais, 2006. p. 605.

${ }^{102}$ NERY JUNIOR, Nelson, apud TAVARES, André Ramos. Op. Cit., p. 180.
} 
Com efeito, a Constituição Federal prestigia o princípio do duplo grau de jurisdição, ainda que de forma implícita, ao (i) traçar o perfil estrutural do Poder Judiciário, institucionalizar o Supremo Tribunal Federal e o Superior Tribunal de Justiça e disciplinar a competência dos tribunais superiores para julgamento do recurso ordinário, extraordinário e especial $^{103}$; (ii) indicar de modo expresso que as Justiças dos Estados contarão com tribunais $e$ juízes $^{104}$, prevendo, pois, a existência de diversos juízos, distribuídos em diferentes instâncias e graus de jurisdição, dentro de uma estrutura hierárquica própria ${ }^{105}$; e (iii) garantir a ampla defesa, com os "meios e recursos" (o termo recursos é utilizado em sentido lato, de forma que abrange a acepção estrita do vocábulo) ${ }^{106}$.

Assim, quando a Constituição institucionaliza os tribunais superiores, disciplina sua competência recursal e indica de modo expresso que as Justiças dos Estados serão compostas por tribunais e juízes, ela fixa o duplo grau de jurisdição ${ }^{107} 108$.

O duplo grau de jurisdição é, portanto, prestigiado como princípio pela Constituição Federal de 1988, mas não como direito fundamental nem como garantia constitucional. A diferença é sutil, mas de grande importância prática já que, não havendo garantia

\footnotetext{
103 Artigos 102, II e III, e 105, II e III.

${ }^{104}$ Artigo 92, inc. VII.

${ }^{105}$ Idem, p. 177.

${ }^{106}$ MACHADO, Denise Maria Weiss de Paula; LEAL JÚNIOR, João Carlos. Análise crítica do duplo grau de jurisdição sob o prisma do direito à razoável duração do processo. Revista de Processo, vol. 183, maio/2010, p 88.

${ }^{107}$ É importante ressaltar que a Constituição Federal não obriga, mas apenas prevê a possibilidade de existência de recursos na legislação infraconstitucional.

108 Neste tocante, são relevantes os ensinamentos de Cândido Rangel Dinamarco: Dessas disposições infere-se a intenção de oferecer os serviços jurisdicionais a serem prestados em diversos níveis; pode-se também inferir a exigência de que, no âmbito de cada Justiça, a lei ordinária garanta o direito a um recurso de devolução plena e condicionada somente à sucumbência, como é a apelação. A própria Constituição deixa nítida, contudo, a opção por negar recursos dessa ordem em relação às causas de competência originaria dos tribunais em geral, notadamente dos locais, cujas decisões somente poderão ser objeto de recursos condicionados a requisitos muito específicos, como o extraordinário e o especial. Esse quadro, associado ao completo silencio constitucional quanto a uma suposta garantia do duplo grau de jurisdição (e a Constituição de 1988 é tão pródiga e explicita ao enunciar garantias), mostra que fica somente o conselho (a) ao legislador, no sentido de que evite confinar causas a um nível só, sem a possibilidade de um recurso amplo e (b) ao juiz, para que, em casos duvidosos, opte pela solução mais liberal, inclinando-se a afirmar a admissibilidade do recurso. Essa é a função dos princípios nortear legislador e juiz, em busca da coerência no sistema e justiça nas decisões, sem se impor de modo absoluto". (DINAMARCO, Cândido Rangel. Nova Era ... Op. cit., p. 168/169).
} 
constitucional do duplo grau, mas mera previsão, o legislador infraconstitucional pode limitar o direito de recurso. ${ }^{109}$

Deste modo, diferentemente dos demais princípios integrantes da tutela constitucional do processo ${ }^{110}$, a observância do duplo grau de jurisdição pela lei não é obrigatória, de forma que nada impede a possibilidade de aludido princípio ter sua incidência afastada em determinadas situações, sem que haja ofensa ao que preconiza a Constituição ${ }^{111}$. Assim, excepcionalmente, lei ordinária poderia, em determinadas circunstâncias, impedir o manejo de recurso contra determinada decisão ${ }^{112} 113$, sem ser qualificada de inconstitucional ${ }^{114} 115$.

Por fim, necessário mencionar ser comumente invocado o argumento de que o duplo grau de jurisdição passou a representar garantia constitucional após a ratificação da Convenção Americana sobre Direitos Humanos (Pacto de são José da Costa Rica) ${ }^{116}$, cujo art. $8, \mathrm{n}^{\mathrm{o}} 2$, letra $h$, dispõe que: “(...) durante o processo, toda pessoa tem direito, em plena igualdade, às seguintes garantias mínimas: (...) h) direito de recorrer da sentença para juiz ou tribunal superior" ${ }^{\prime 11}$. Os que se opõem a este posicionamento afirmam que o Pacto assegura o

${ }^{109}$ NERY JUNIOR, Nelson. Princípios do processo civil na Constituição Federal, São Paulo: Revista dos Tribunais, 2004, p. 167.

${ }^{110}$ No entender de Oreste Nestor de Souza Laspro, o duplo grau de jurisdição não é um dos elementos formadores do devido processo legal, já que não constitui garantia de uma decisão melhor e tampouco de isenção do juízo e de efetiva defesa das partes (Duplo grau de jurisdição no direito processual civil. São Paulo: Revista dos Tribunais, 1995, p. 94)

${ }^{111}$ NOGUEIRA, Mauricio José. Op. Cit., p. 544.

${ }^{112}$ MARCATO, Ana C. Menezes. Op. Cit., p. 30.

${ }^{113}$ Oreste Nestor de Souza Laspro, por outro lado, entende que o duplo grau de jurisdição está garantido na Constituição em uma única hipótese, qual seja, a do recurso ordinário (Garantia do duplo grau de jurisdição. In TUCCI, José Rogério Cruz e (coord.). Garantias Constitucionais do Processo Civil - Homenagem aos 10 anos da Constituição Federal de 1988. São Paulo: Revista dos Tribunais, 1999, p. 203/206).

${ }^{114}$ WAMBIER, Luiz Rodrigues. Op. Cit., p. 340.

${ }^{115}$ Novamente trazemos à baila as lições de Dinamarco que esclarece que as Constituições políticas evitam erigir o duplo grau à condição de garantia, limitando-se a fixar o principio: "A relatividade histórica do princípio, com o qual não são incompatíveis as ressalvas razoavelmente postas pela lei (Chiovenda), levou Liebman a dizer que "o duplo grau, sendo um instituto inspirado em motivos de oportunidade, não exclui atenuações e compromissos quando for o caso de pôr em confronto com outras exigências eventualmente conflitantes" (essa ressalva é de destacada importância metodológica, como adiante se procura demonstrar). O importante, diz ainda o Mestre, é que o principio do duplo grau deve ser visto como uma regra geral inerente ao sistema democrático do processo. Não obstante as variações a que é institucionalmente sujeito, esse principio integra o conjunto democrático dos modelos processuais inerentes ao Estado-de-direito e, mais precisamente, a clausula due process of law. Ele representa, agora na lição de Chiovenda, "uma garantia dos cidadãos". (DINAMARCO, Cândido Rangel. Nova Era ..., Op. cit., p. 168).

${ }^{116}$ Promulgado pelo Decreto Presidencial no 678 de 06.11.1992.

${ }^{117}$ GRINOVER, Ada Pellegrini. Op. Cit., p. 41. 
direito de recorrer, que não se confunde com o duplo grau de jurisdição e que a mera previsão de recursos não garante, necessariamente, a possibilidade de reexame total da matéria já analisada em um primeiro momento ${ }^{118}$.

${ }^{118}$ TAVARES, André Ramos. Op. Cit., p. 185. 


\section{CAPÍtUlo 2 - A OPÇÃo PELO JULGAMENTO COLEGIADO DOS RECURSOS}

\section{O julgamento colegiado - razões e justificativas}

A função jurisdicional pode ser exercida tanto por juízo único - caso em que recebe a denominação de juízo singular, individual, unipessoal, único ou monocrático -, como por juízo constituído de diversas pessoas "que cooperam em forma tal, que suas atividades aparecem no processo como expressão de uma vontade unitária" ${ }^{" 19}$, recebendo a alcunha de colegiado, coletivo ou agremiado.

No órgão judiciário colegiado, as manifestações singulares de cada juiz que participa do julgamento são progressivamente tomadas e reunidas para formar uma decisão unitária denominada acórdão ${ }^{120}$.

Mencione-se, ainda, a existência de sistema denominado eclético, no qual os litígios de menor potencial econômico ou complexidade são analisados por juízos unipessoais enquanto que os julgamentos dos de maior potencial e complexidade são atribuídos a órgãos colegiados.

No nosso sistema processual, regra geral, os julgamentos afetos aos tribunais, notadamente os dos recursos, são feitos de forma coletiva, através da formação da vontade colegiada que é tomada por maioria de votos ${ }^{121}$.

Esta estrutura recursal colegiada representa uma tentativa de superar a fragilidade de uma decisão lançada por único magistrado. Tem-se que o reexame do feito em grau recursal, por órgão formado por vários julgadores, teoricamente dotados de maior experiência no trato

\footnotetext{
${ }^{119}$ CARVALHO, Fabiano. Poderes do relator nos recursos: art. 557 do CPC. São Paulo: Saraiva, 2008, p. 3.

${ }^{120}$ Barbosa Moreira esclarece que "é evidente que, num determinado instante do procedimento de votação, os pronunciamentos de todos os votantes hão de ter idêntico objeto, sob pena de somarem-se quantidades heterogêneas, o que não permite chegar a nenhuma conclusão válida. Ou todos estão se manifestando acerca da preliminar, ou todos acerca do mérito. Não é concebível que, na mesma etapa, um (ou alguns) votem quanto à preliminar e outro (ou outros) quanto ao mérito". BARBOSA MOREIRA, José Carlos. Direito Aplicado II, p. 126.

${ }^{121}$ Giuseppe Chiovenda. Instituições de Direito Processual Civil, vol. 3, p. 33
} 
de matérias jurídicas, diminui a possibilidade do cometimento de erros ${ }^{122}$. Nos dizeres de Fabiano Carvalho, "Por essa razão, os julgamentos coletivos traduzem maior segurança para as partes, e a probabilidade de justiça é maior."123.

Pontes de Miranda afirma que a pluralidade de julgadores tem "o fim político de assegurar diversos exames ao mesmo tempo, além do duplo ou múltiplo exame, no tempo, pelo juiz de primeiro grau e os demais juízes superiores". E continua: "A ciência ensina-nos, hoje, que a assembleia não veio da reflexão, foi a reflexão que veio da assembleia. Essa prioridade do exame múltiplo ao mesmo tempo, em relação ao exame de um só, transforma em superioridade sempre que desejamos maior certeza. A colegialidade para a decisão dos recursos obedece a esse pender intimo do homem quando se deseja guiar pela "razão'."124.

As vantagens e desvantagens do juízo singular em relação ao colegiado foram bem delineadas por Chiovenda: “o juiz singular tem maior sentimento de responsabilidade; isto, porém, pode, por um lado, ser perigoso, e, de outro, é passível de conseguir-se também no juiz colegial, tornando-se públicas as deliberações. $O$ juiz singular não está sujeito à preponderância dos colegas, mas está mais exposto às pressões da opinião pública, dos litigantes, das autoridades superiores; tem um conhecimento mais imediato dos atos do processo, mas pode mais facilmente apreciá-los de modo subjetivo ou errado. Vantagens indiscutíveis do sistema do juiz singular são as possibilidades de formas processuais mais simples e de melhor seleção pessoal"125.

A colegialidade, por outro lado, é também um importante fator de busca de legitimidade do Judiciário na medida em que persuade o jurisdicionado que a sua causa foi julgada por uma junta de juízes, que discutiram a matéria procurando em conjunto encontrar a solução mais justa, "juízes que revelaram o direito das partes no exercício mais autêntico do mandato recebido do povo e sob o mais eficaz mecanismo de controle, aquele que cada

\footnotetext{
${ }^{122}$ CAVAlCANTE, Mantovanni Colares. Os meios de Controle das decisões monocráticas do relator em tribunais, Os poderes do juiz e o controle das decisões judiciais - estudos em homenagem à Professora Teresa Arruda Alvim Wambier, São Paulo: RT, 2008, p. 794

${ }^{123}$ CARVALHO, Fabiano. Poderes do relator nos recursos: art. 557 do CPC. São Paulo: Saraiva, 2008. p.4.

${ }^{124}$ Pontes de Miranda, Comentários ao Código de Processo Civil, t. VII, p. 7

${ }^{125}$ Instituiciones del nuevo processo civil italiano, p. 126.
} 
julgador exerce sobre o comportamento dos demais porque a decisão que todos buscam vai influir na reputação de cada uma"126.

Como veremos em capítulo próprio, historicamente, o julgamento colegiado foi o procedimento adotado em nossos tribunais. No entanto, o excesso de feitos submetidos à apreciação dos Tribunais ocasionou a alteração desse panorama pelo legislador através do alargamento dos poderes do relator, a permitir-lhe até mesmo o julgamento de mérito do recurso por decisão singular.

\section{Os poderes do relator no direito estrangeiro}

\subsection{Europa}

$\mathrm{Na}$ Itália, o sistema processual civil foi significativamente modificado pelas Leis $\mathrm{n}^{\mathbf{o}}$ 353, de 26.11.1990 e 374, de 21.11.1991, as quais trouxeram inovações notadamente no que toca aos recursos.

Ao contrário do sistema processual brasileiro, em que os poderes do relator foram gradativamente ampliados, na reforma processual civil italiana os poderes do instruttore contemplados no art. 350 do Codice di procedura civile foram reduzidos ${ }^{127}$. Esse dispositivo, alterado pelo art. 55 da Lei 353 de 1990, determina que a trattazione da apelação deve ser colegiada, e não monocrática, como ocorria anteriormente ${ }^{128}$.

\footnotetext{
${ }^{126}$ Leonardo Greco, A falência do sistema de Recursos, Revista dialética de Direito Processual, n. 1, p. 102-103. ${ }^{127}$ Art. 350. (Trattazione)

Davanti alla corte di appello la trattazione dell'appello è collegiale ma il presidente del collegio può delegare per l'assunzione dei mezzi istruttori uno dei suoi componenti $\left(^{2}\right)$; davanti al tribunale l'appello è trattato e deciso dal giudice monocratico.

Nella prima udienza di trattazione il giudice verifica la regolare costituzione del giudizio e, quando occorre, ordina l'integrazione di esso o la notificazione prevista dall'art. 332, oppure dispone che si rinnovi la notificazione dell'atto di appello.

Nella stessa udienza il giudice dichiara la contumacia dell'appellato, provvede alla riunione degli appelli proposti contro la stessa sentenza e procede al tentativo di conciliazione ordinando, quando occorre, la comparizione personale delle parti.

${ }^{128}$ JORGE, Flavio Cheim, p. 28 e ss
} 
Giuseppe Tarzia esclarece que a norma do art. 350 optou pela rigorosa colegialidade do julgamento, em detrimento da forma monocrática, ao dispor que o tratamento da apelação é colegiado $^{129}$, o que, para Aldo Attardi, desprestigia o instruttore (relator) com a consequente divisão de funções entre o relator e o colegiado ${ }^{130}$.

Ao analisar as diferenças entre os sistemas brasileiro e italiano, Cândido Rangel Dinamarco assinala que "a tendência brasileira a ampliar os poderes do relator vem de encontro à linha adotada na Itália, onde em tempo recente se deu precisamente o contrário. $\mathrm{O}$ art. 350 do códice di procedure civile, que atribuía uma série grande de atividades ao instruttore em grau de apelação, foi alterado pela Reforma de 1990. Operou-se então uma visível e intencional opção pela "rigorosa colegiata del processo d' apelo in ogni sue fase", inclusive mediante "la conseguente sopressione dela figure del giudice instruttore" (Giuseppe Targio)", e conclui: "Essa observação em nada desmerece o que no Brasil se vem fazendo, dado que se trata de opções de caráter pragmático destinadas a dar solução a dificuldades contingenciais da vida judiciaria de cada pais" ${ }^{\prime 131}$.

No direito alemão, ao revés do italiano, nota-se tendência análoga à brasileira de atribuir e de concentrar poderes decisórios em matéria de recursos nos membros do tribunal. Adverte Barbosa Moreira que, no entanto, a orientação vem sendo adotada na Alemanha de modo mais cauteloso uma vez que o $§ 526,1^{\text {a }}$ alínea, do Zivilprozessordnung (“ZPO”), na redação dada pela lei de $27.7 .2001^{132}$, dispõe que "o Einzelrichter só se investe da função de decidir mediante delegação do colegiado, subordinada a certos pressupostos"133.

\footnotetext{
129 "La scelta di fondo (como si è detto) è stata quella per la integrale, rigorosa collegialità del processo d'appello in ogni sua fase, con la conseguente soppressione dela figura dell'instruttore" (Lineamenti del nuovo processo di cognizione, pag. 249).

${ }^{130}$ ATTARDI, Aldo Le nuove disposizioni sul processo civile, pag. 167

${ }^{131}$ DINAMARCO, C. R. Fundamento do Processo Civil Moderno, Tomo II, p. 1103.

132 § 526 Entscheidender Richter

(1) Das Berufungsgericht kann durch Beschluss den Rechtsstreit einem seiner Mitglieder als Einzelrichter zur

Entscheidung übertragen, wenn

1. die angefochtene Entscheidung von einem Einzelrichter erlassen wurde,

2. die Sache keine besonderen Schwierigkeiten tatsächlicher oder rechtlicher Art aufweist,

3. die Rechtssache keine grundsätzliche Bedeutung hat und

4. nicht bereits im Haupttermin zur Hauptsache verhandelt worden ist, es sei denn, dass inzwischen ein Vorbehalts-, Teil- oder Zwischenurteil ergangen ist.

(2) Der Einzelrichter legt den Rechtsstreit dem Berufungsgericht zur Entscheidung über eine Übernahme vor, wenn
} 
Já na França, a colegialidade é adotada como regra geral tanto na $1^{\mathrm{a}}$ instância quanto na recursal, à exceção dos casos em que se adota o sistema de juiz único (Tribunais de Instância e juízes de menores). Segundo Luiz Guilherme Marques, "Dos órgãos todos jurisdicionais que mencionamos, cujo número excede a 30 , somente dois trabalham no sistema de juiz único: os Tribunais de Instância e os Juízes de Menores. Fala-se em França que toda decisão colegiada tem mais chance de ser acertada. Essa tese é levada às últimas consequências e chega a criar resistência de muitos quando se trata dos Tribunais de Instância e quando outros pretendem que os juízes dos Tribunais de Grande Instância possam trabalhar no sistema de juiz único. As necessidades atuais de simplificação, agilidade e baixo custo financeiro têm trabalhado contra a colegialidade." ${ }^{\prime 34}$.

$\mathrm{O}$ autor menciona, ainda, que no sistema francês, a possibilidade de julgamento monocrático pelos presidentes dos Tribunais de Grande Instância, salvo se disciplinar ou de estado das pessoas, já era admitida desde o início dos anos 1970 e que é forte o movimento de juristas no sentido de atenuar cada vez mais a colegialidade dos julgamentos em todos os tipos de jurisdição: de direito comum e de exceção, e em todos os terrenos da atividade jurisdicional: jurisdição voluntária ou contenciosa, matéria de mérito bem como preparatória ou provisória.

O direito português, por sua vez, nada menciona sobre atribuições conferidas ao relator, no sentido de julgar isoladamente o mérito dos recursos. No entanto, com relação à admissibilidade, o Código de Processo Civil português preceitua que quando as razões

1. sich aus einer wesentlichen Änderung der Prozesslage besondere tatsächliche oder rechtliche Schwierigkeiten der Sache oder die grundsätzliche Bedeutung der Rechtssache ergeben oder 2. die Parteien dies übereinstimmend beantragen.

Das Berufungsgericht übernimmt den Rechtsstreit, wenn die Voraussetzungen nach Satz 1 Nr. 1 vorliegen. Es entscheidet hierüber nach Anhörung der Parteien durch Beschluss. Eine erneute Übertragung auf den Einzelrichter ist ausgeschlossen.

(3) Auf eine erfolgte oder unterlassene Übertragung, Vorlage oder Übernahme kann ein Rechtsmittel nicht gestützt werden.

(4) In Sachen der Kammer für Handelssachen kann Einzelrichter nur der Vorsitzende sein.

${ }^{133}$ BARBOSA MOREIRA, Reformas Processuais e Poderes do Juiz, Revista da EMERJ, v. 6, n. 22, 2003

${ }^{134}$ Luiz Guilherme Marques, O Processo Civil Francês, Revista da EMERJ, v. 13, $n^{o}$ 49, 2010. 
recursais forem deficientes, “o relator deve convidar o recorrente a apresentá-las, contemplálas, esclarecê-las ou sintetizá-las" (art. 690, n. 4).

\subsection{Estados Unidos}

Os processos são geralmente divididos em categorias baseadas na natureza de suas reivindicações: Local, Federal, Internacional e Militar. Uma decisão de um Tribunal Local poderia ser apelada em um Tribunal de Recursos da respectiva região. No nível federal, iria para a Suprema Corte. Os casos internacionais vão para o Tribunal das Reivindicações (“Court of claims"); e os casos militares vão para o Tribunal de Justiça Militar.

No sistema federal, a parte vencida, regra geral, tem o direito de recorrer da decisão a um tribunal federal de recursos ${ }^{135}$. O recorrente deve mostrar que no primeiro julgamento houve um erro jurídico que afetou a decisão sobre o caso. $\mathrm{O}$ tribunal de recursos poderá rever as constatações de fato que foram levadas em consideração pelo julgador a quo, mas as questões de fato somente podem fundamentar a revisão da decisão caso as conclusões a respeito deste fato sejam "claramente erradas".

O sistema norte-americano privilegia o julgamento colegiado dos recursos, que são decididos por painéis de três juízes que trabalham em conjunto. Quando uma apelação é apresentada, o Tribunal de Recursos irá revisar o caso e decidir se precisa ou não ser reavaliado. Durante esse processo, o réu, conhecido como apelante, ou seu representante, apresenta um resumo dos acontecimentos do caso, conhecido como sumário jurídico, que precisa ter alguns tipos de prova ou argumentos persuasivos de que ocorreu um erro legal, demonstrando o porquê da necessidade da reforma da decisão anterior. No julgamento de primeira instância, o processo é tipicamente supervisionado por um único juiz. No entanto, no Tribunal de Recursos, o processo é avaliado por três juízes que compõe um painel ("panel”).

\footnotetext{
${ }^{135}$ Da mesma forma, nos casos em que um litigante não se conformar com uma decisão de um órgão da administração federal, poderá apresentar um pedido de revisão da decisão da agência por um tribunal de apelação. A revisão judicial nos casos que envolvem certas agências federais ou programas - por exemplo, as disputas sobre benefícios da Previdência Social - pode ser obtida pela primeira vez em um tribunal distrital em vez de um tribunal de apelação.
} 
A despeito de alguns casos serem decididos unicamente com base nestes documentos apresentados pelas partes, muitas vezes o painel convoca as partes para apresentarem "alegações" perante o tribunal. "Alegações" são discussões estruturadas a respeito dos fundamentos legais em disputa entre os advogados das partes e os juízes que compõem o painel de juízes. O sistema norte-americano prevê que a decisão pode ser revista "en banc", ou seja, por um grupo maior de juízes (geralmente todos) integrantes do Tribunal.

Mencione-se que a parte vencida pode, ainda, apresentar um "writ of certiorari", que é um documento pedindo à Suprema Corte para analisar o caso. A Suprema Corte, no entanto, não está obrigada a efetuar novo julgamento do caso, selecionando apenas as controvérsias envolvendo ou um princípio jurídico extremamente importante ou interpretação divergente de dois ou mais tribunais de apelação federais. Por outro lado, se o Tribunal de Recursos aprova a apelação, o caso é enviado à Suprema Corte (independente do tipo de tribunal do qual a apelação tenha se originado).

A Suprema Corte é constituída por nove juízes, conhecidos como ministros. Um deles é o Presidente e os demais são ministros associados. Todos são nomeados pelo Presidente dos Estados Unidos. Aqui está uma nota interessante: o número de ministros tem sido nove desde 1869, mas na verdade é um critério do Congresso. A Suprema Corte tem uma jurisdição sobre todos os tribunais nos Estados Unidos e é a maior autoridade no âmbito judicial do governo. Qualquer que seja sua decisão, esta não poder ser apelada. Ademais, uma apelação aprovada não significa, necessariamente, que a Suprema Corte irá aceitar o caso; apenas significa que a apelação foi enviada para a instância superior. Os ministros decidem o que irão julgar: recebem em torno de 700 pedidos para serem a apreciados durante um ano e julgam apenas 80. Se a apelação não for apreciada pela instância superior, a decisão original permanece. 


\section{CAPÍTULO 3 - MITIGAÇÃo DA COLEGIALIDADE E AMPLIAÇÃo DOS PODERES DO RELATOR}

\section{A realidade forense e a crise do Poder Judiciário}

De acordo com levantamento feito pelo Conselho Nacional de Justiça - CNJ ${ }^{136}$, 65,7 milhões de processos estavam em andamento na Justiça Estadual em $2010^{137}$, sendo que 17,7 milhões de processos haviam sido ajuizados naquele ano ${ }^{138}$. Os números apontam um acréscimo de $0,8 \%$ em comparação com o ano anterior, causado pelo aumento de 2,5\% no quantitativo de casos pendentes.

O estudo aponta, ainda, que em 2010 tramitaram 3,3 milhões de processos em $2^{\circ}$ grau da Justiça Estadual, sendo que 43,6\% eram casos pendentes de julgamento desde o final de 2009 e 56,4\% eram casos novos. Nesse período, o Tribunal de Justiça de São Paulo foi responsável por $28 \%$ dos processos novos em $2^{\circ}$ grau e $28,3 \%$ das decisões terminativas proferidas em $2^{\circ}$ grau, conforme tabela abaixo:

\begin{tabular}{|c|c|c|c|}
\hline Casos novos & Casos pendentes & Processos baixados & $\begin{array}{c}\text { Decisões } \\
\text { terminativas }\end{array}$ \\
\hline 521.534 & 714.100 & 455.229 & 505.656 \\
\hline
\end{tabular}

Outro dado relevante é o número de processos baixados por caso novo, que reflete a vazão dos Tribunais e o acúmulo de processos para o ano seguinte. Embora o desempenho médio dos tribunais tenha superado o resultado de 2009, nenhum tribunal de grande porte conseguiu baixar mais processos do que o fluxo de entrada do ano.

\footnotetext{
136 http://www.cnj.jus.br/images/programas/justica-em-numeros/2010/rel_justica_numeros_2010.pdf, acessado em 7.11.2011

${ }^{137}$ Soma entre o total de casos novos e o total de casos pendentes.

${ }^{138} 640$ mil processos a menos que no ano anterior (2009).
} 
Por fim, segundo o movimento judiciário divulgado pela Corregedoria Geral da Justiça, em 2011 ${ }^{139}$, na Justiça Estadual de São Paulo, havia 19.074.604 processos em andamento, tendo sido proferidas 3.031.719 sentenças em $1^{\mathrm{a}}$ instância.

\begin{tabular}{|c|c|c|c|c|}
\hline Mês / 2011 & Em andamento & Distribuídos & Audiências & Sentenças \\
\hline Janeiro & 18.647 .294 & 346.618 & 40.821 & 212.219 \\
\hline Fevereiro & 18.959 .073 & 401.913 & 127.236 & 308.100 \\
\hline Março & 18.996 .622 & 401.511 & 129.389 & 359.378 \\
\hline Abril & 18.972 .651 & 372.062 & 117.160 & 363.070 \\
\hline Maio & 18.967 .507 & 449.951 & 138.688 & 391.541 \\
\hline Junho & 18.984 .735 & 406.559 & 126.227 & 349.432 \\
\hline Julho & 19.055 .043 & 466.116 & 96.764 & 322.009 \\
\hline Agosto & 19.084 .430 & 582.857 & 145.656 & 381.229 \\
\hline Setembro & 19.074 .604 & 453.089 & 124.843 & 344.741 \\
\hline Total & ------ & $\mathbf{3 . 8 8 0 . 6 7 6}$ & $\mathbf{1 . 0 4 6 . 7 8 4}$ & $\mathbf{3 . 0 3 1 . 7 1 9}$ \\
\hline
\end{tabular}

Tais números demonstram a ineficiência do que está sendo feito para que sejam extirpados os males de nossa Justiça ${ }^{140}$, de modo que o sistema jurídico processual não mais se mostra idôneo e eficaz para a realização efetiva dos direitos. ${ }^{141} 142$

\section{O acesso à justiça, a efetividade e a razoável duração do processo}

\subsection{Conteúdo e alcance}

A Constituição Imperial do Brasil (1824), quando tratava da nota de culpa, já se referia ao prazo razoável (179 VIII).

\footnotetext{
${ }^{139}$ Até setembro de 2011, inclusive.

${ }^{140}$ DINAMARCO, Cândido Rangel. Nova Era ..., p.13

${ }^{141}$ MARCATO, Antônio Carlos. "Considerações sobre a tutela jurisdicional diferenciada", in http://www.mundojuridico.adv.br/sis_artigos/artigos.asp?codigo=249, acesso em 30.3.2010

${ }^{142}$ Segundo Carnelutti, as causas da ineficiência da Justiça dividem-se em (i) a lei processual, (ii) as estruturas judiciárias; e (iii) o homem que opera o direito (DINAMARCO, Cândido Rangel. Nova Era ..., p. 15)
} 
Art. 179. A inviolabilidade dos Direitos Civis, e Políticos dos Cidadãos Brazileiros, que tem por base a liberdade, a segurança individual, e a propriedade, é garantida pela Constituição do Império, pela maneira seguinte:

VIII. Ninguém poderá ser preso sem culpa formada, excepto nos casos declarados na Lei; e nestes dentro de vinte e quatro horas contadas da entrada na prisão, sendo em Cidades, Villas, ou outras Povoações próximas aos logares da residência do Juiz; e nos logares remotos dentro de um prazo razoável, que a Lei marcará, attenta a extensão do território, o Juiz por uma Nota, por elle assignada, fará constar ao Réo o motivo da prisão, os nomes do seu accusador, e os das testemunhas, havendo-as.

A Convenção Americana dos Direitos e dos Deveres do Homem, conhecida como Pacto de São José da Costa Rica, estabelece, em seu art. $8^{\circ}$, as garantias judiciais a serem observadas:

Artigo $8^{\circ}$ - Garantias judiciais

1. Toda pessoa terá o direito de ser ouvida, com as devidas garantias e dentro de um prazo razoável, por um juiz ou Tribunal competente, independente e imparcial, estabelecido anteriormente por lei, na apuração de qualquer acusação penal formulada contra ela, ou na determinação de seus direitos e obrigações de caráter civil, trabalhista, fiscal ou de qualquer outra natureza.

Todavia, tal dispositivo não significou automática adoção do princípio da razoável duração do processo no âmbito cível, já que sua interpretação restrita conduz à conclusão de que a duração razoável do processo é garantia prevista para o processo penal.

Entretanto, levando-se em consideração que os direitos humanos e fundamentais merecem interpretação ampliativa, é possível afirmar que a duração razoável do processo deveria ser observada no processo judicial (penal e civil) e no processo administrativo.

A EC 45/04 acrescentou ao rol dos direitos fundamentais da CF o inciso LXXVIII do art. $5^{\circ}$, por meio do qual assegurou expressamente, no âmbito judicial e administrativo, a 
razoável duração do processo e os meios que garantam a celeridade de sua tramitação. Essas previsões - razoável duração e celeridade - já estavam contempladas no texto constitucional, seja no princípio do devido processo legal, no princípio do direito de ação ou de acesso à justiça ou ainda no da eficiência da administração pública.

Importante destacar que a excessiva duração do processo judicial não tem sido preocupação apenas brasileira; as constituições italiana, portuguesa, espanhola e a convenção europeia de direitos humanos também adotaram regra semelhante.

Mas como saber se o processo teve duração razoável, considerando as diferenças muitas vezes gritantes entre os casos concretos, seus procedimentos, necessidade de produção de provas etc?

No âmbito da União Europeia e em varias decisões do Tribunal Europeu de Direitos Humanos foram fixados alguns critérios para aferição da duração razoável do processo, quais sejam, (i) a natureza do processo; (ii) a complexidade da causa; (iii) o comportamento das partes e dos procuradores; e (iv) a atividade e comportamento das autoridades judiciárias e administrativas competentes ${ }^{143}$.

O princípio da duração razoável do processo possui dupla função: fazer com que seja respeitado o tempo do processo em sentido estrito e com que se adotem meios alternativos de solução de conflitos, de sorte a aliviar a carga de trabalho na justiça ordinária.

Não significa, no entanto, que deva se observar a celeridade em detrimento de outros princípios e garantias; a justiça tem de ser feita da forma mais rápida possível, sempre observados os preceitos constitucionais, como devido processo legal, isonomia, contraditório, ampla defesa, juiz natural, etc.

\footnotetext{
${ }^{143}$ Nelson Nery Jr traz mais um critério - a fixação legal de prazos para a pratica de atos processuais que assegure o direito ao contraditório e à ampla defesa.
} 


\subsection{Efetividade da razoável duração do processo}

A confiança nos provimentos jurisdicionais e sua legitimidade são cada vez mais atacadas pela sociedade, enfrentando o Poder Judiciário uma verdadeira crise de legalidade e da justiça ${ }^{144}$. Não são novos os debates acerca da excessiva morosidade existente no Poder Judiciário brasileiro e da necessidade de alteração da situação ${ }^{145}$.

Nesse contexto, uma das questões que mais tem preocupado os pensadores do direito é acesso à justiça, como diz Comoglio ${ }^{146}$ : "l'accesso alla giustizia significa (e non protebbe non significare) per qualsiasi individuo la incondizionata ed effettiva liberta di agire gli organi giurisdizionali, al fine di domandare (ed, a processo concluso, eventualmente ottenere) la tutela adeguata ed effettiva dei diritti o degli interessi sostanziali fatti valere".

E ligado ao acesso à justiça está o conceito da efetividade da tutela jurisdicional, que depende da observância, em especial, do escopo social do processo de pacificar com justiça e a necessidade de que essa pacificação seja obtida de forma célere ${ }^{147}$, em tempo razoável ${ }^{148}$.

Nesse sentido, José Rogério Cruz e Tucci ${ }^{149}$ afirma que: "Não deve apenas outorgar uma satisfação jurídica às partes, como também, para que essa resposta seja a mais plena possível, a decisão final deve ser pronunciada em um lapso de tempo compatível com a natureza do objeto litigioso, visto que - caso contrário - se tornaria utópica a tutela jurisdicional de qualquer direito. Como já se afirmou, com muita razão, para que a justiça seja injusta não faz falta que contenha equívocos, basta que não julgue quando deve julgar".

\footnotetext{
${ }^{144}$ LINS, Rodrigo Martiniano Ayres. Op. Cit., p. 181.

${ }^{145}$ MACHADO, Denise Maria Weiss de Paula; LEAL JÚNIOR, João Carlos., Op. Cit., p. 102.

${ }_{146}$ COMOGLIO, Luigi Paolo. Accesso alle corti e garanzie costituzionali. In Estudos em homenagem à Professora Ada Pellegrini Grinover. Coord. de Flávio L. Yarshell e Maurício Zanóide de Moraes. São Paulo: DPJ Editora, 2005, p. 277.

${ }^{147}$ Lembramos que a celeridade processual foi elevada à categoria de garantia constitucional com o advento da EC 45/2004, que incluiu o inc. LXXVIII ao art. $5^{\circ}$ da Constituição Federal.

${ }^{148}$ MARCATO, Ana C. Menezes. Op. Cit., p. 39.

${ }^{149}$ CRUZ E TUCCI, José Rogério. Garantia do processo sem dilações indevidas, In Revista Jurídica, no 277, nov. 2000, p. $6 / 7$.
} 
E continua: "Não se pode olvidar, nesse particular, a existência de dois postulados que, em princípio, são opostos: o da segurança jurídica, exigindo, como já salientado, um lapso temporal razoável para a tramitação do processo ("tempo fisiológico"), e o da efetividade deste, reclamando que o momento da decisão final não se procrastine mais do que o necessário ("tempo patológico"). Obtendo-se o equilíbrio desses dois regramentos - segurança/celeridade -, emergirão as melhores condições para garantir a justiça no caso concreto, sem que, assim haja diminuição no grau de efetividade da tutela jurisdicional”.

Neste passo, a duração de forma razoável, para Wambier, "será aquela em que melhor se puder encontrar o meio termo entre a definição segura da existência do direito e realização rápida do direito cuja existência foi reconhecida pelo juiz" ${ }^{\prime 150}$. Não se quer, pois, dizer que a rapidez deve estar acima de tudo. Barbosa Moreira ${ }^{151}$ tece oportunas críticas à crença de que "quanto mais depressa melhor", lembrando que (i) a questão da morosidade não é fenômeno exclusivamente brasileiro; (ii) muitas vezes os jurisdicionados não clamam pela solução rápida dos litígios, pelo contrário, desejam que o feito se prolongue tanto quanto possível; (iii) a maior responsabilidade pela duração excessiva dos pleitos não decorre da legislação processual; e (iv) a lentidão não se sobrepõe a todos os demais problemas da Justiça.

É necessário, portanto, alcançar-se o equilíbrio entre certeza e razoável duração do processo para se chegar ao acesso à ordem jurídica adequadamente tempestiva. No quesito certeza, sobressai a importância do duplo grau de jurisdição na medida em que, em tese, tanto mais justa e acertada será a decisão quanto mais ela for examinada. Por outro lado, é necessário que o processo seja breve e que a decisão definitiva seja proferida sem procrastinações inúteis e no menor tempo possível ${ }^{152}$, não podendo ser permitido que os litígios se perpetuem indefinidamente no tempo, sob o pretex to de conferir maior segurança à parte que esta em juízo buscando o atendimento de sua pretensão ${ }^{153}$.

\footnotetext{
${ }^{150}$ WAMBIER, Luiz Rodrigues; ARRUDA ALVIM WAMBIER, Teresa; MEDINA, José Miguel Garcia. Breves comentários à nova sistemática processual civil: Emenda Constitucional n. 45/2004 (reforma do Judiciário); Lei 10.444/2002; Lei 10.358/2001 e Lei 10.352/2001. 3. ed. Rev. Atual. E ampli. São Paulo: Ed. RT, 2005, p. 29/-30. ${ }^{151}$ BARBOSA MOREIRA, José Carlos, O futuro da justiça: alguns mitos, In Revista da Associação dos Magistrados Brasileiros - Cidadania e Justiça, v. 4, no 8, p. 7-10, jan/jun 2000.

${ }^{152}$ GRINOVER, Ada Pellegrini.. Op. Cit., p. 39.

${ }^{153}$ MARCATO, Ana C. Menezes. Op. Cit., p. 40.
} 
Bem se vê que o princípio do duplo grau de jurisdição encontra-se em meio a esses dois fatores. Embora sua observância possibilite a consecução de uma tutela mais adequada e justa, o duplo grau de jurisdição e os recursos são tidos, por muitos, como verdadeiros óbices à busca da celeridade. Isso porque a enorme quantidade de recursos existente somada às numerosas possibilidades de interposição (e a sua interposição, muitas vezes, com fins meramente protelatórios ${ }^{154}$ ) posterga em muito a duração do processo, além de contribuir para a sobrecarga dos Tribunais e agravar a lentidão existente no tramite processual.

Assim, a segurança proclamada como fundamento do reexame redunda na instabilidade da ordem jurídica posta, na medida em que a decisão prolatada em $2^{\mathrm{a}}$ instância acaba se tornando censurável por ser intempestiva. Quanto maior for a duração do processo, mais ele se presta a prejudicar o autor que tem razão e a premiar o réu que não a tem ${ }^{155}$. Um processo que se estende por anos gera insegurança e desprestigia o sistema legal.

O desafio dos sistemas processuais modernos é o de conciliar e harmonizar esse aparente conflito entre justiça célere e certeza. Como decorrência deste pensamento, têm surgido na doutrina corrente favorável a se restringir os meios recursais como forma de atingir, em um menor espaço de tempo, a certeza jurídica e a efetividade do processo e de se descongestionar as vias de acesso aos tribunais, hoje sobrecarregados com um volume gigantesco de demandas. ${ }^{156}$

Para que se dê efetividade à garantia constitucional da celeridade é necessário equiparse o Judiciário do aparato logístico de que precisa para dar cumprimento ao comando constitucional. Alexandre de Moraes afirma que "a real efetividade do princípio não depende

154 ROCCO, Ugo apud MARQUES, José Frederico. Instituições de Direito processual civil, Campinas: Millenium, 1999: "per cui gli organi giurisdizionali, com poteri e limiti, specificamente determinati dal diritto processuali obiettivo, possono riesaminare il prodotto dell'attività degli organi giurisdizionale"

${ }^{155}$ LINS, Rodrigo Martiniano Ayres. Op. Cit., p. 181/182.

${ }^{156}$ Luiz Rodrigues Wambier diz que "[os recursos] têm sido apontados como os grandes "culpados" por todos os males do serviço judiciário brasileiro. Fizemos, durante quase 50 anos, intenso discurso de acesso à justiça. Conclamamos a sociedade a acreditar no sistema. E, agora, lamentavelmente, que essa mesma sociedade demonstra ter acreditado, porque veio, e veio intensivamente, com suas múltiplas demandas por justiça, pensamos, na doutrina, com inspiração em setores da jurisprudência, em eliminar hipóteses de controle das decisões judiciais pela via recursal; pensamos e propomos alterações legislativas que deixam de considerar a estrutura constitucional do direito fundamental de acesso à justiça e, assim por diante" ( Op. Cit., p. 333). 
apenas do poder judiciário e de seus juízes, mas principalmente dos poderes executivo e legislativo e da mudança da mentalidade dos governantes e políticos, no sentido de cumprirem e fazerem cumprir a constituição" ${ }^{157}$.

Como vimos, a Emenda Constitucional n 45/04 assegurou a razoável duração do processo e os meios que garantam a celeridade de sua tramitação. Mas não foi só. A emenda trouxe também mecanismos de celeridade e desburocratização, como a vedação de férias coletivas nos juízos e nos tribunais de segundo grau, a proporcionalidade do número de juízes à efetiva demanda judicial e à respectiva população, a distribuição imediata dos processos em todos os graus de jurisdição, a possibilidade de delegação aos servidores do Judiciário para a prática de atos de administração e atos de mero expediente sem caráter decisório, a necessidade de demonstração da repercussão geral das questões constitucionais, a instalação da justiça itinerante, e as súmulas vinculantes.

Entretanto, foram poucos os instrumentos processuais trazidos pela $E C n^{\circ} 45 / 05$. As reformas do Código de Processo Civil, que também tiveram por objetivo dinamizar o processo e garantir maior rapidez, não tiveram o condão de, de fato, acelerar os trâmites de procedimento e julgamento, de modo que a lentidão com que a justiça responde às demandas, "institucionalizando o conflito em vez de decidi-lo com presteza"158, ainda é o problema primordial a ser enfrentado.

\subsection{Conselho Nacional de Justiça e efetivação do princípio}

O Conselho Nacional de Justiça, criado em dezembro de 2004 para auxiliar o Poder Judiciário, instituiu algumas medidas para viabilizar a tramitação dos processos em um período que se possa considerar razoável.

\footnotetext{
${ }^{157}$ Conselho Nacional de Justiça e efetivação do princípio da celeridade processual: procedimento por excesso de prazo. Revista de Direito Administrativo, vol. 243, set./dez./2006, Rio de Janeiro: Fundação Getúlio Vargas/Renovar/Atlas, p.275-282.

${ }^{158}$ Moraes, Alexandre de . Conselho Nacional de Justiça e efetivação do princípio da celeridade processual: procedimento por excesso de prazo. Revista de Direito Administrativo, vol. 243, set./dez./2006, Rio de Janeiro: Fundação Getúlio Vargas/Renovar/Atlas, p.275-282.
} 
A primeira delas é a representação por excesso injustificado de prazo contra magistrado, que poderá ser formulada por qualquer interessado, MP, presidentes dos tribunais, de ofício, pelos conselheiros e deverá ser apresentada em 2 vias, instruída com os documentos essenciais à comprovação e dirigida ao ministro corregedor.

Outra medida foi o desenvolvimento do mutirão "Judiciário em Dia', para acelerar os julgamentos na Justiça Federal através de uma força-tarefa que vai "promover mudanças significativas na forma de julgamento para reduzir o acervo de processos dos tribunais regionais federais, possibilitando a tramitação mais rápida das demandas judiciais" ${ }^{\prime 159}$.

O Tribunal Regional Federal da $3^{a}$ Região recebeu a equipe do CNJ e estabeleceu-se o objetivo de julgar mais de 80 mil processos e garantir o cumprimento da Meta 2, de julgar todas as ações que ingressaram no tribunal antes de 31 de dezembro de 2006.

Por fim, o CNJ tem estabelecido metas prioritárias anuais, sendo que no $3^{\circ}$ Encontro Nacional do Judiciário foram definidas 10 Metas Prioritárias para 2010, assim resumidas:

- Meta 1: julgar quantidade igual à de processos de conhecimento distribuídos em 2010 e parcela do estoque, com acompanhamento mensal;

- Meta 2: julgar todos os processos de conhecimento distribuídos (em $1^{\circ}$ grau, $2^{\circ}$ grau e tribunais superiores) até 31 de dezembro de 2006 e, quanto aos processos trabalhistas, eleitorais, militares e da competência do tribunal do Júri, até 31 de dezembro de 2007;

- Meta 3: reduzir em pelo menos $10 \%$ o acervo de processos na fase de cumprimento ou de execução e, em 20\%, o acervo de execuções fiscais (referência: acervo em 31 de dezembro de 2009);

- Meta 4: lavrar e publicar todos os acórdãos em até 10 dias após a sessão de julgamento;

- Meta 5: implantar método de gerenciamento de rotinas (gestão de processos de trabalho) em pelo menos $50 \%$ das unidades judiciárias de $1^{\circ}$ grau;

${ }^{159}$ http://www.cnj.jus.br/ 
- Meta 6: reduzir a pelo menos $2 \%$ o consumo per capita com energia, telefone, papel, água e combustível (ano de referência: 2009);

- Meta 7: disponibilizar mensalmente a produtividade dos magistrados no portal do tribunal;

- Meta 8: promover cursos de capacitação em administração judiciária, com no mínimo 40 horas, para 50\% dos magistrados;

- Meta 9: ampliar para 2 Mbps a velocidade dos links entre o Tribunal e 100\% das unidades judiciárias instaladas na capital e, no mínimo, 20\% das unidades do interior; e

- Meta 10: realizar, por meio eletrônico, 90\% das comunicações oficiais entre os órgãos do Poder Judiciário.

\subsection{Celeridade e os recursos protelatórios}

Atribui-se ao duplo grau de jurisdição a excessiva duração dos processos, em virtude da enorme gama de recursos previstos na legislação, que muitas vezes são usados por razões protelatórias.

Ives Gandra da Silva Martins ${ }^{160}$ aponta as três principais motivações da protelação: (i) retardar o desfecho final do processo, para furtar-se, ainda que temporariamente dos efeitos financeiros da sentença; (ii) insistência, à saciedade, ainda que sem reais possibilidades, de reverter as decisões desfavoráveis, percorrendo insistentemente a via sacra recursal; e (iii) manutenção do processo na instância, sem prosseguimento, tendo em vista a remuneração do advogado por peca processual, por tempo ou pelo numero de processos que acompanha.

O autor defende que, embora os recursos protelatórios sejam inevitáveis, eles podem ser combatidos mediante a aplicação das penalidades dos art. 17, 18, 538, §único e 557, § $2^{\circ}$ do CPC e conclui: "Somente com a sensibilidade do advogado para distinguir sobre a conveniência ou não de recorrer, conjugada com o destemor do juiz na aplicação das normas

160 MARTINS, Ives Gandra da Silva. A garantia constitucional da celeridade processual e os recursos protelatórios. Revista de Direito Administrativo, vol. 243, set./dez./2006, Rio de Janeiro: Fundação Getúlio Vargas/Renovar/Atlas, p.71-78. 
legais de combate à protelação, sem receio de melindres e suscetibilidades por parte dos causídicos que patrocinam as causas, é que se poderá dar efetiva celeridade ao processo. Do contrario, não há reforma que baste, pois será o juiz quem terá de aplicar a norma processual, podendo dar-lhe toda a forca normativa ou dela fazer letra morta”.

\subsection{Celeridade no Projeto do 'novo' Código de Processo Civil}

A Comissão de Juristas encarregada de elaborar o anteprojeto de novo Código do Processo Civil afirma que seu objetivo precípuo foi o de garantir um novo Código de Processo Civil que privilegie a simplicidade da linguagem, a celeridade do processo e a efetividade do resultado: "É que, aqui e alhures, não se calam as vozes contra a morosidade da justiça. O vaticínio tornou-se imediato: 'justiça retardada é justiça denegada' e com esse estigma arrastou-se o Poder Judiciário, conduzindo o seu desprestígio a índices alarmantes de insatisfação aos olhos do povo. Esse o desafio da comissão: resgatar a crença no judiciário e tornar realidade a promessa constitucional de uma justiça pronta e célere. Como vencer o volume de ações e recursos gerado por uma litigiosidade desenfreada, máxime num país cujo ideário da nação abre as portas do judiciário para a cidadania ao dispor-se a analisar toda lesão ou ameaça a direito? Como desincumbir-se da prestação da justiça em um prazo razoável diante de um processo prenhe de solenidades e recursos? (...) Para esse desígnio, a primeira etapa foi a de detectar as barreiras para a prestação de uma justiça rápida; a segunda, legitimar democraticamente as soluções".

O ministro Luiz Fux, um dos responsáveis pela elaboração do anteprojeto, afirmou que o alvo foi a "tormentosa" morosidade da justiça brasileira, causado pelo formalismo dos processos, pelo excesso de recursos aos tribunais e pela litigiosidade desenfreada no país desde os anos 70 .

Uma das providências adotadas foi a de limitar o uso de recursos, com, p.e., do agravo de instrumento e dos embargos de declaração. Além disso, pretende-se sejam extintos os embargos infringentes. Outras propostas que tem por fim limitar o uso dos recursos são: (i) limitação das hipóteses de recebimento da apelação com efeito suspensivo; (ii) limitação das 
hipóteses de cabimento da apelação com base no valor da causa; (iii) exigência de depósito prévio do valor da condenação em sede de apelação a fim de desestimular a sua interposição; e (iv) imposição de sucumbência em grau recursal. 


\section{CAPITULO 4 - A AMPLIAÇÃO DOS PODERES DO RELATOR}

\section{As atribuições do relator}

Nos termos do artigo 548 do Código de Processo Civil, a escolha do relator é feita de acordo com o regimento interno do tribunal, observando-se os princípios da publicidade, da alternatividade e do sorteio.

O relator atua como o condutor do processo no tribunal ${ }^{161}$ e suas atribuições variam conforme se trate de recurso ou de causa da competência originária do tribunal. Sua atividade pode ser dividida em quatro fases distintas e dependentes entre si que variam de recurso para recurso: ordinatória, preparatória, instrutória e decisória ${ }^{162}$. A atividade é ordinatória quando o relator coloca o recurso em ordem, podendo, p.e., requisitar informações do juiz prolator da decisão agravada, mandar ouvir o Ministério Público, ou, ainda, determinar se proceda à intimação do agravado para que apresente resposta ${ }^{163}$. É preparatória quando o relator providencia as condições para julgamento do recurso (como elaboração de relatório) e instrutória, como o nome diz, quando há produção de (novas) provas.

Já no que se refere à atividade decisória propriamente dita, o relator poderá conceder efeito suspensivo ao agravo nos termos do artigo 558 do Código de Processo Civil (desde que admitido o recurso e a requerimento do agravante) e negar seguimento, negar provimento ou mesmo prover o recurso nas hipóteses do artigo 557 do Código de Processo Civil.

Incumbe ao relator, ainda, (i) processar o incidente de impedimento ou suspeição suscitado no tribunal, quanto a órgão do Ministério Público, serventuário ou funcionário da Justiça, perito ou intérprete (artigo 138, §2 $2^{\circ}$ ); (ii) processar o incidente de falsidade documental, quando suscitado no tribunal (artigo 393); (iii) requisitar às repartições públicas, quando for o caso, as certidões necessárias à prova das alegações das partes e os

\footnotetext{
${ }^{161}$ VICARI, Marcio Luiz Fogaça. Antecipação da tutela recursal e competência do relator. Revista Forense, Rio de Janeiro: Forense, vol. 353, jan./fev./2001, p. 215.

${ }^{162}$ CARVALHO, Fabiano. Poderes do relator nos recursos: art. 557 do CPC. São Paulo: Saraiva, 2008, p. 9.

${ }^{163}$ TUCCI, Jose Rogério Cruz e. Sobre a atividade decisória do relator do agravo de instrumento. Revista Forense, Rio de Janeiro, v.93, n.338, abr./jun. 1997, p. 411.
} 
procedimentos administrativos nas causas em que forem interessados a União, o Estado, o Município, ou as respectivas entidades da administração indireta (artigo 399); (iv) decretar medidas cautelares, quando o feito estiver no tribunal (artigo 800, parágrafo único); (v) processar a habilitação quando os autos estiverem no tribunal (artigo 1.059); (vi) processar a restauração dos autos desaparecidos no tribunal (art. 1.068); e (vii) julgar os incidentes que não dependam de acordão e executar as diligências necessárias para o julgamento, inclusive no sentido de suprir as deficiências da instrução ${ }^{164}$.

Além disso, segundo estabelece o artigo 555 do Código de Processo Civil, o relator, após estudar os autos - e obviamente ressalvado o disposto no artigo 557 e seu $\S 1^{\circ}$-A - os restituirá à secretaria com o seu "visto" e com "uma exposição dos pontos controvertidos sobre que versar o recurso"165. Anote-se que, após lançar seu visto nos autos, o relator deverá, obrigatoriamente e sob pena de nulidade, participar da sessão de julgamento, salvo nos casos de afastamento definitivo (v.g., aposentadoria, falecimento, exoneração) ou temporário (v.g. moléstia, viagem urgente) ${ }^{166}$. Por fim, nas sessões de julgamento, o relator deve fazer “a exposição da causa" (artigo 554), proferir o primeiro voto e redigir o acórdão nos casos em que a tese jurídica por ele desenvolvida for vencedora (artigo 556). ${ }^{167}$.

Como veremos, a esfera de competência do relator foi consideravelmente dilatada pelas recentes reformas legislativas.

\footnotetext{
164 BARbOSA MOREIRA, José Carlos. Comentários ao Código de Processo Civil, Lei $n^{\circ}$ 5.869, de 11 de janeiro de 1973: art. 476 a 565, vol. V. Rio de Janeiro: Editora Forense, 2008, p. 650.

${ }_{165}^{165}$ BARBOSA MOREIRA, José Carlos. Comentários... Op. cit., p. 649.

${ }^{166}$ CARVALHO, Fabiano. Op. cit., p .9.

${ }^{167}$ VIVEIROS, Estefânia. Agravo interno no Superior Tribunal de Justiça e ampliação dos poderes do relator. Universitas/Jus, Brasília, n.7, jul./dez. 2001, p.62.
} 


\section{Histórico do artigo 557 do Código de Processo Civil}

\subsection{Antecedentes históricos ${ }^{168}$}

No período entre o fim da civilização antiga e o surgimento dos Estados Nacionais, houve a centralização do poder de julgar, sendo atribuída ao soberano a concretização da justiça para seus súditos.

Tal justiça, por reflexo da sociedade na época, surgiu estratificada, ou seja: o julgador poderia julgar as questões dos seus inferiores, mas apenas mediar as questões entre seus iguais, sendo que "social e politicamente foram dadas as condições para o restabelecimento das regras de hierarquia e apelação (ordinária ou extraordinária).”

Na Idade Média, em decorrência da separação de jurisdição entre Estado e Igreja, desenvolveram-se as regras de competência (matéria, território, pessoa). Definiram-se, também, regras de competência: a disputa entre comerciantes era decidida pelas corporações; as disputas entre os clérigos, nos tribunais eclesiásticos; os militares eram julgadas por tribunais militares.

Afirma José Reinaldo Lopes que “julgando casos e categorias específicas de pessoas, os tribunais especiais tendiam a desenvolver regras particulares: tanto no que diz respeito ao processo propriamente dito (provas admissíveis, por exemplo) quanto ao direito em geral (regras sobre contratos, interpretação do silêncio, presunção de responsabilidade, repartição de custos, etc.)".

A presença de leigos no universo jurídico fez com que as conclusões fossem proferidas sem fundamentação jurídica propriamente dita, de modo que o júri não justificava seu veredito. Assim, não se podia recorrer da decisão do júri: “se o júri afirmava que fulano não estava em tal lugar em tal hora, um tribunal superior não poderia afirmar o contrário, poderia

\footnotetext{
${ }^{168}$ LOPES, José Reinaldo de Lima. Fundamentos de História do Direito. 3. Ed. Belo Horizonte: Del Rev. 2006. Capítulo 16.
} 
anular o julgamento por falsidade: não, porém, reinterpretar a decisão. Isto porque o júri afirmava o que vira e ouvira".

As formas de julgamento foram continuamente burocratizadas e o processo passou a ter fases mais precisas. E a tarefa de julgar do clero acabou sendo transferida para o tribunal de juristas especializados. A institucionalização dos recursos colaborou para a passagem gradual do processo canônico para o burocrático - ou moderno - já que as autoridades superiores eram convocadas a reavaliar, corrigir ou policiar os atos das autoridades locais.

A evolução do procedimento de julgar exigiu a sofisticação dos mecanismos processuais, definindo, cada vez mais, as regras regimentais para a uniformização dos tribunais para exercerem um poder centralizador.

Para facilitar um sistema organizado de recursos - no qual houvesse uma supervisão permanente pelas instâncias superiores das instâncias inferiores - a uniformização do processo fez-se fundamental. Consolidou-se um regime de controle, "no qual a função do tribunal superior era desconfiar do julgamento do tribunal inferior: desconfiar institucionalmente, não pessoalmente, e o instrumento da desconfiança era a prova formalizada - por ela o tribunal superior podia, sem julgar o tribunal inferior, desfazer ou reverter a respectiva decisão."

\subsection{Antecedentes do artigo 557 do Código de Processo Civil (em sua redação atual)}

O Supremo Tribunal Federal, diante do aumento significativo do número de processos a ele submetidos e da consequente sobrecarga das suas sessões de julgamento, em 28 de agosto de 1963, alterou a redação do art. 15, IV, do seu Regimento Interno, autorizando o relator a determinar o arquivamento ${ }^{169}$ do recurso extraordinário ou do agravo de instrumento quando o pedido do recorrente contrariasse jurisprudência sumulada ${ }^{170}$. Alfredo Buzaid ${ }^{171}$ ressaltou, na ocasião, que a mudança visava a eliminar de plano um número considerável de

169 Para Fabiano Carvalho, “a expressão 'mandar arquivar' também alcançava o mérito do recurso". CARVALHO, Fabiano. Op. cit., p.14.

${ }^{170}$ Idem, p.13/14.

${ }^{171}$ BUZAID, Alfredo. Estudos de direito. São Paulo: Saraiva, 1972, vol. I, p. 204/205. 
recursos, de modo que fossem incluídas em pauta apenas as causas que merecessem efetiva apreciação pela Turma ou pelo Plenário.

No mesmo ano, em sessão plenária realizada em 13 de dezembro de 1963, o Supremo Tribunal Federal editou a Súmula n 322 que dispunha que "não terá seguimento pedido ou recurso dirigido ao Supremo Tribunal Federal, quando manifestamente incabível, ou apresentado fora do prazo, ou quando for evidente a incompetência do tribunal".

Outro dispositivo legal que ampliou os poderes do relator foi o art. 90, $\S 2^{\circ}$ da Lei Complementar $\mathrm{n}^{\circ}$ 35, de 14 de março de 1979 (Lei Orgânica da Magistratura Nacional "LOMN"), ao autorizar o relator de recursos dirigido ao antigo Tribunal Federal de Recursos a julgar monocraticamente "pedido ou recurso que manifestamente haja perdido objeto" e a mandar arquivar ou negar seguimento a "pedido ou recurso manifestamente intempestivo ou incabível ou, ainda, que contrariar as questões predominantemente de direito, súmula do Tribunal ou do Supremo Tribunal Federal" ${ }^{172}$. O dispositivo trazia, ainda, a previsão do cabimento de agravo, no prazo de cinco dias, para o órgão do Tribunal competente, para o julgamento do pedido ou recurso e dispunha que o relator da votação não participaria do julgamento do recurso $^{173}$.

Em 15 de outubro de $1980^{174}$, o Supremo Tribunal Federal aprovou seu Regimento Interno, cujo artigo $21, \S 1^{\circ}$, autorizava o relator a "arquivar ou negar seguimento a pedido ou recurso manifestamente intempestivo, incabível ou improcedente e, ainda, quando contrariar a jurisprudência predominante do Tribunal ou for evidente a sua incompetência."175 176.

\footnotetext{
${ }^{172}$ SLAIBI FILHO, Nagib. Notas sobre o art. 557 do CPC (competência do relator de prover e negar seguimento a recurso). Revista Forense, Rio de Janeiro, v. 98, n.361, maio/jun. 2002, p.95.rodape

${ }^{173}$ CARVALHO, Fabiano. Op. cit., p. 15.

${ }^{174}$ O dispositivo, publicado no DOU de 27.10.1980, entrou em vigor em $1^{\circ}$ de dezembro de 1980.

175 SLAIBI FILHO, Nagib. Op. cit., p. 96 e CARNEIRO, Athos Gusmão. Poderes do relator e agravo interno: art. 557, 544 e 545 do CPC. Revista de Processo, São Paulo, v.25, n.100, out./dez. 2000, p. 11.

${ }^{176}$ Segundo Eduardo Ribeiro de Oliveira, a palavra "arquivamento" significava que realmente o recurso poderia ser desde logo decidido, por contrariar a jurisprudência assente, não sendo necessária sua submissão ao colegiado. Apud CARVALHO, Fabiano. Op. cit., p.16.
} 
No ano de 1985, por meio da Emenda Regimental $n^{\circ} 2^{177}$, foi alterado o $§ 2^{\circ}$ do artigo 21 do Regimento Interno do Supremo Tribunal Federal ${ }^{178}$, para permitir que o relator desse provimento a recurso extraordinário em caso de manifesta divergência com a Súmula.

Inspirado no $\S 1^{\circ}$ do art. 22 do RISTF, o art. 38 da Lei $n^{\circ} 8.038$, de 28 de maio de 1990, atribuiu poderes ao relator do Supremo Tribunal Federal e do Superior Tribunal de Justiça para decidir, monocraticamente, "o pedido ou o recurso que haja perdido seu objeto, bem como negara seguimento a pedido ou recurso manifestamente intempestivo, incabível ou, improcedente ou ainda, que contrariar, nas questões predominantemente de direito, Súmula do respectivo Tribunal".

Conforme análise de Barbosa Moreira “das várias espécies de inadmissibilidade, só se mencionavam duas (intempestividade e descabimento), embora por via hermenêutica se pudesse ampliar as restantes (deserção, falta de legitimação para recorrer etc.) a área de incidência da disposição" ${ }^{179}$.

No âmbito do Superior Tribunal de Justiça, os poderes do relator foram ampliados por meio da Emenda Regimental $\mathrm{n}^{\circ}$ 1, de 23 de maio de 1991, que alterou o art. 34 do seu Regimento Interno para permitir que o relator negue seguimento a pedido ou recurso manifestamente intempestivo, incabível, improcedente, contrário a súmula do Tribunal, ou quando for evidente a incompetência deste ${ }^{180}$.

\footnotetext{
${ }^{177}$ Disponível em http://www.stf.jus.br/ARQUIVO/NORMA/EMENDAREGIMENTAL002-1985.PDF

178 "§ $2^{\circ}$ Poderá ainda o relator, em caso de manifesta divergência com a Súmula, prover, desde logo, o recurso extraordinário".

${ }^{179}$ BARBOSA MOREIRA, José Carlos. Inovações da Lei 9.756 em matéria de recursos civis. In WAMBIER, Teresa Arruda Alvim; NERY JUNIOR, Nelson (coord.). Aspectos polêmicos e atuais dos recursos cíveis de acordo com a Lei 9.756/98. São Paulo: Revista dos Tribunais, 1999 , p. 322.

${ }^{180}$ Disponível em

http://bdjur.stj.gov.br/xmlui/bitstream/handle/2011/7754/EMENDA_REGIMENTAL_1_23-05-

1991.pdf? sequence $=1$
} 


\subsection{O artigo 557 do Código de Processo Civil}

\subsubsection{A redação original do artigo 557 do Código de Processo Civil}

Com severas críticas lançadas pela doutrina e o surgimento de várias leis extravagantes, tornou-se necessária a reformulação do Código de Processo Civil de 1939. Assim, o governo Federal incumbiu o professor Alfredo Buzaid de elaborar o anteprojeto do Código de Processo Civil. Em 1969, o anteprojeto de Buzaid e sua exposição de motivos, após serem analisados por uma Comissão composta por Machado Guimarães, José Frederico Marques e Luiz Antônio de Andrade, resultaram no Projeto de Lei $\mathrm{n}^{\circ}$ 810/72 e, posteriormente, na Lei $\mathrm{n}^{\circ} 5.869 / 73$ de 11.1.1973, que instituiu o Código de Processo Civil vigente até hoje ${ }^{181}$.

O artigo 557 do Código de Processo Civil, inspirado no artigo 21, § $1^{\circ}$, do Regimento Interno do Supremo Tribunal Federal ${ }^{182}$, em sua redação original, dispunha: “Art. 557. Se o agravo for manifestamente improcedente, o relator poderá indeferi-lo por despacho. Também por despacho poderá convertê-lo em diligência se estiver insuficientemente instruído. Parágrafo único. Do despacho de indeferimento caberá recurso para o órgão a que competiria julgar o agravo".

Interessante notar que a disposição não constava do Anteprojeto ${ }^{183}$, tampouco do Projeto de Lei $\mathrm{n}^{\circ} 810 / 72^{184}$; o artigo $604^{185}$ do Anteprojeto e o artigo $571^{186}$ do Projeto

\footnotetext{
${ }^{181}$ Influenciado pela doutrina de Enrico Túlio Liebman, o Código de Processo Civil de 1973 foi estruturado a partir da clássica divisão das espécies de tutela jurisdicional em tutela de conhecimento, tutela de execução e tutela cautelar. Liebman sustentava que "no sistema do direito processual, a única classificação legítima e importante é a que se refere à espécie do provimento pedido", sendo que, "sob este ponto de vista, as ações distinguem-se em três categorias: a) as ações de conhecimento; b) as ações executivas; c) as ações cautelares". (OLIVEIRA, Celso Marcelo. Moderno Direito Processual Civil do Brasil e Portugal. Boletim Jurídico, Uberaba/MG, a. 4, no 151. Disponível em: 〈http://www.boletimjuridico.com.br/ doutrina/texto.asp?id=903> Acesso em 30.3.2010).

${ }^{182}$ FERREIRA FILHO, Manoel Caetano. O Indeferimento liminar do agravo de instrumento pelo relator. Revista de Processo, São Paulo, v.18, n.69, jan/mar. 1993, p. 230.

${ }^{183}$ Disponível em http://www2.senado.gov.br/bdsf/bitstream/id/177246/1/anteprojeto\%20de\%20codigo\%20de\%20processo\%20civi 1.pdf

${ }^{184}$ Disponível em http://www2.senado.gov.br/bdsf/bitstream/id/177828/1/CodProcCivil\%201974.pdf

185 Art. 604. O agravo de instrumento será conhecido. ainda quando insuficientemente instruído. O tribunal
} 
dispunham somente acerca da conversão do agravo em diligência e incumbiam a tarefa ao Tribunal. Segundo Alexandre de Paula, a alteração das disposições a fim de conferir ao relator o poder de indeferir (rectius: negar seguimento) o agravo de instrumento foi proposta pelo Senador Accioly Filho, relator-geral da Comissão do Senado, que defendeu que a técnica constava do Regimento Interno do Supremo Tribunal Federal e dava bons resultados ${ }^{187}$.

$\mathrm{O}$ artigo 557 do CPC, em sua redação originária, dizia respeito tão-somente ao recurso de agravo (em sua modalidade "por instrumento") 188 e continha, como bem advertiram Athos Gusmão Carneiro $^{189}$ e Antonio Carlos Marcato ${ }^{190}$, manifestas impropriedades de redação. O texto legal denominava despacho um ato claramente decisório como o que indefere liminarmente um recurso (artigo 162 do CPC) e utilizava o termo indeferir quando, tecnicamente, o correto seria negar seguimento ao agravo. Além disso, não se convertia em diligência o próprio agravo; a rigor, sustava-se o julgamento do recurso para que, mediante diligência, fosse complementada sua instrumentação.

Sérgio Bermudes, à época, manifestou o entendimento de que a expressão "manifestamente improcedente" também deveria abranger os agravos manifestamente "inadmissíveis": "Assim, agravo manifestamente improcedente será aquele cujas condições de admissibilidade não estejam configuradas, mas, também, aquele interposto de decisão que a jurisprudência tenha, reiteradamente, prestigiado, ou que se tenha limitado a aplicar dispositivo de lei"191.

converterá o julgamento em diligência. a fim de que se complete a trasladação das peças, impondo à parte negligente multa correspondente a dez (10) vezes o valor das custas.

186 Artigo 571. Quando o agravo de instrumento não estiver suficientemente instruído, o Tribunal converterá o julgamento em diligência, a fim de que se complete a trasladação das peças.

${ }_{187}$ PAULA, Alexandre de, apud CARVALHO, Fabiano. Op. cit., p.16.

${ }^{188}$ CIANCI, Mirna. A lei n. 9.756/1998 (CPC, artigos 544, par. 3 e 557, pars. 1 a 3) e a ampliação dos poderes do relator, dez anos depois. Revista Brasileira de Direito Processual, Belo Horizonte, v.16, n.61, jan/mar. 2008, p. 104.

${ }^{189}$ CARNEIRO, Athos Gusmão. Op. cit., p. 12.

${ }^{190}$ MARCATO, Antonio Carlos (coord.). Código de Processo Civil interpretado. São Paulo : Atlas, 2004.

${ }^{191}$ BERMUDES, Sérgio. Comentários ao Código de Processo Civil. São Paulo: RT, 1975, vol. VII, n. 239. 
A redação original do parágrafo único do artigo 557 do Código de Processo Civil tampouco escapou das críticas, já que criava um recurso novo (inominado) e não fixava prazo para sua interposição, nem regulava seu processamento ${ }^{192}$.

\subsubsection{Notas sobre as Reformas do Código de Processo Civil}

Antes de ingressar no exame propriamente dito das alterações promovidas pelas Leis n. 9.135/95 e 9.756/98, é necessário fazer uma pequena digressão acerca das premissas teóricas que nortearam os trabalhos de reforma do Código de Processo Civil.

As Reformas do Código de Processo Civil tiveram, como objetivo central, a aceleração da tutela jurisdicional e, como postura metodológica predominante, a disposição de liberar-se de poderosos dogmas plantados na cultura processualística ocidental ao longo dos séculos. ${ }^{193}$

Dinamarco lembra que o processualista, no final do século $\mathrm{XX}$, estava submetido a exagerado conceitualismo e a uma intensa preocupação garantística que, "concebidos para serem fatores de consistência metodológica de uma ciência, chegaram ao ponto de se transmudar em grilhões de uma servidão perversa."194

Nesse aspecto, são relevantes as ideias de Cappelletti e Garth, responsáveis pelo estabelecimento do panorama da necessidade de acesso ao judiciário, que reconhecem três movimentos que denominaram de "ondas renovatórias": a primeira, ligada à criação da assistência judiciária para pessoas de baixa renda; a segunda diz respeito à representação dos interesses coletivos; e a terceira trata de uma concepção mais ampla de acesso à justiça, centrando-se nas instituições, mecanismos, pessoas e procedimentos utilizados para processar e mesmo prevenir disputas nas sociedades modernas.

\footnotetext{
192 CARVALHO, Fabiano. Op. cit., p.16/17

193 DINAMARCO, Cândido Rangel. Nova Era do Processo Civil. $3^{\text {a }}$ ed. São Paulo: Malheiros, 2009, p. 20.

${ }^{194}$ Idem, p. 20.
} 
A preocupação, pois, era a de permitir o acesso à ordem jurídica justa, assim entendida como aquela que permite a obtenção de resultados justos em tempo razoável ${ }^{195}$. Deste modo, passou-se a entender que não tinha garantido o acesso à justiça aqueles que não conseguiam fazer-se ouvir em juízo, como também todos os que, em virtude das mazelas do processo, recebiam uma justiça tardia ou alguma injustiça de qualquer ordem. ${ }^{196}$

A reforma do Código de 1973 foi precedida por um estudo realizado no ano de 1985, quando o Ministro da Justiça Fernando Lyra designou uma comissão composta pelos professores Luís Antônio de Andrade, José Joaquim Calmon de Passos, Kazuo Watanabe, Joaquim Correa de Carvalho Junior e Sérgio Bermudes, para elaborar um anteprojeto de modificação do Código de Processo Civil.

As conclusões da Comissão foram apresentadas ao Ministério da Justiça em 1985, porém esse anteprojeto não foi levado adiante, sendo que sequer entrou em fase de procedimento legislativo. Segundo apurou Fabiano Carvalho, em 1986, foi apresentado, por Athos Gusmão Carneiro, Luiz Melibio Uiraçaba Machado e Ovídio A. Baptista da Silva, Substitutivo ao Anteprojeto de Reforma do CPC, que propunha alterar a redação do art. 557 do CPC para permitir o indeferimento liminar não só do agravo como também da apelação, nos casos de ostensiva inadmissibilidade ou manifesta improcedência. Nos dizeres dos autores, tal medida poderia contribuir para desafogar a pauta dos Tribunais e foi empregada com real utilidade, nos casos de agravo, no Tribunal de Justiça do Rio Grande do Sul. Da decisão do relator, o substitutivo, igualmente à norma original, previa recurso para o colegiado, no prazo de 15 dias. Anotaram, também, que tal recurso era utilizado muito limitadamente, concluindo-se pela utilidade prática do indeferimento liminar dos recursos ${ }^{197}$.

Neste cenário foram implantadas as mudanças no Código de Processo Civil, consubstanciadas em várias leis portadoras de inovações setoriais, ou minirreformas,

\footnotetext{
${ }^{195}$ Nunca é demais lembrar a máxima de Chiovenda, erigida em verdadeiro slogan, segundo a qual "na medida do que for praticamente possível o processo deve proporcionar a quem tem um direito tudo aquilo que ele tem direito de obter."

${ }^{196}$ MARCATO, Ana C. Menezes. Op. Cit., p. 134.

${ }^{197}$ CARVALHO, Fabiano. Op. cit., p.17/18.
} 
responsáveis pelas alterações em diversos pontos da nossa legislação ${ }^{198}$. Os anteprojetos que tiveram por objetivo o aperfeiçoamento do Código visavam, precipuamente, a remover óbices à efetividade do acesso à justiça, os quais se localizam em quatro pontos sensíveis do sistema, representados pela admissão em juízo; pelo modo-de-ser do processo; pela justiça das decisões e pela sua efetividade, ou utilidade.

\subsubsection{As alterações promovidas pela Lei $n^{\circ} 9.139 / 95$}

Na década de 90 é iniciado um movimento renovador do Código de Processo Civil pela Associação dos Magistrados Brasileiros e pelo Instituto Brasileiro de Direito Processual (IBDP). Em 1992, o movimento foi absorvido pela Escola Nacional de Magistratura, por incumbência do Ministro da Justiça, Jarbas Passarinho, sendo constituída uma comissão de juristas para estudar o problema da morosidade processual, dos óbices à efetividade do acesso à justiça e propor soluções visando à simplificação do Código de Processo Civil brasileiro.

A comissão, presidida pelo diretor da Escola e Ministro do Superior Tribunal de Justiça, Sálvio de Figueiredo Teixeira e secretariada por Fátima Nancy Andrighi, então desembargadora do Tribunal de Justiça do Distrito Federal e Territórios, era composta por Athos Gusmão Carneiro Ministro, Ada Pellegrini Grinover, Celso Agrícola Barbi, Humberto Theodoro Júnior, José Carlos Barbosa Moreira, José Eduardo Carreira Alvim, Kazuo Watanabe e Sérgio Sahione Fadel.

\footnotetext{
${ }^{198}$ Importante destacar, neste tocante, que o legislador optou por fazer "minirreformas", ou seja, reformas de forma setorizada (ao contrário de uma reforma global e abrangente), retocando alguns institutos e introduzindo alterações em capítulos, de modo que os problemas fossem atacados de modo específico. Além disso, optou-se por não guerrear o código nem postular sua substituição de modo que fosse viabilizada sua aprovação pelo Congresso Nacional.

O Prof. Dinamarco chega a falar em "estratégia de guerrilha contra os pontos débeis do sistema", afirmando que a soma das reformas introduziu uma profunda alteração no Código. Ainda segundo o prof. Dinamarco, "as grandes estruturas movimentam-se lentamente, e convém que assim seja, porque movimentos bruscos podem ser a causa de rupturas ou fissuras em estruturas de grande porte, como é a ordem jurídica e como é a máquina judiciária.” (DINAMARCO, Cândido Rangel. Nova Era... Op. cit., p. 16).
} 
Assim, a primeira grande reforma do Código de Processo Civil, iniciada nos idos de 1994, buscou pela abreviação de procedimentos e eliminação de etapas mortas do processo ${ }^{199}$.

Por intermédio da Lei $\mathrm{n}^{\circ}$ 9.139, de 30.11.1995, que alterou a sistemática do agravo, o legislador reformista ampliou as atribuições dos relatores, passando o artigo 557 do Código de Processo Civil à seguinte redação: “Art. 557 - O relator negará seguimento a recurso manifestamente inadmissível, improcedente, prejudicado ou contrário à súmula do respectivo tribunal ou tribunal superior. Parágrafo único - Da decisão denegatória caberá agravo, no prazo de 5 (cinco) dias, ao órgão competente para o julgamento do recurso. Interposto o agravo a que se refere este parágrafo, o relator pedirá dia.”

Como vimos, o texto original do dispositivo dizia respeito apenas ao agravo e somente possibilitava que o relator negasse provimento ao recurso, singularmente, caso este fosse manifestamente inadmissível. A Lei $\mathrm{n}^{\circ}$ 9.139/1995 ampliou sensivelmente os poderes do relator, atribuindo-lhe competência para monocraticamente "negar seguimento" a recurso que fosse manifestamente inadmissível, improcedente, prejudicado ou contrário à súmula do respectivo tribunal ou de tribunal superior. Importante destacar que os poderes foram estendidos para os demais recursos do Código, não se restringindo mais a atuação do relator apenas aos casos de agravo.

Além disso, com a expressão "negar seguimento", o código passou a dar competência para o relator analisar tanto a admissibilidade quanto o próprio "mérito" do recurso, com o poder de negar provimento ao recurso manifestamente improcedente ou quando a tese jurídica base da inconformidade contrariasse súmula do tribunal de destino ou de tribunal superior a respeito da quaestio juris fundamental à solução da lide 200201.

\footnotetext{
${ }^{199}$ CIANCI, Mirna. Op. cit., p103/104. Dos onze anteprojetos de lei apresentados, dez foram convertidos em lei: Leis $\mathrm{n}^{\circ}$ 8.455/92 (perícias), 8.710/93 (citação-intimação via postal), 8.898/94 (liquidação), 8.950/94 (recursos), 8.951/94 (consignação e usucapião), 8.952/94 (processos de conhecimento e cautelar), 8.953/94 (processo de execução), 9.079/95 (ação monitória), 9.139/95 (agravo) e 9.245/95 (procedimento sumário).

${ }^{200}$ CARNEIRO, Athos Gusmão. Op. cit., p. 13

${ }^{201}$ Como bem observou o magistrado Sérgio Ricardo de Arruda Fernandes, "A existência de entendimento sumulado na jurisprudência do próprio tribunal ao qual foi endereçado o recurso, ou de tribunal superior, tornouse um dos fundamentos a autorizar o julgamento da matéria recursal pelo seu relator, como forma de se obter o mais rápido desfecho do procedimento deflagrado na instancia revisora". FERNANDES, Sérgio Ricardo de
} 
Interessante notar que a Lei $\mathrm{n}^{\circ} 9.139 / 95$ permitia que o relator decidisse, sozinho, o mérito do recuso, apenas para negar-lhe, mas nunca para dar-lhe provimento ${ }^{202}$.

Ao analisar essas alterações promovidas pela Lei $\mathrm{n}^{\circ}$ 9.135/95, Cândido Rangel Dinamarco considerou que, "ao conferir ao relator poderes assim tão amplos, a nova lei assumiu o risco de abrir caminho para erros de um juiz singular julgando recursos e sua admissibilidade. Mas é inerente à vida de todo processo um sistema de certezas, probabilidades e riscos - a ser equilibrado mediante a oferta de meios corretivos dos erros que porventura se cometam"203.

Outra importante mudança diz respeito à supressão da possibilidade de o relator sustar o julgamento do agravo para que, mediante diligência, fosse suprida a insuficiência do instrumento.

Por fim, a redação dada pela Lei 9.139/95 corrigiu anteriores impropriedades. A expressão "despacho" constante do texto antigo foi modificada para "decisão" e antigo recurso (inominado) a que iludia o parágrafo único passou a ser denominado "agravo", tendo sido fixado seu prazo em cinco dias ${ }^{204}$.

\subsubsection{As alterações promovidas pela Lei $n^{\circ} 9.756 / 98$}

Em 1998, teve início uma segunda etapa da reforma, com o objetivo de aprimorar a anterior, melhorar o sistema recursal e combater a excessiva lentidão do processo ${ }^{205}$.

Arruda. A influência da jurisprudência dos tribunais no julgamento realizado na instância revisora. Revista de Direito do Tribunal de Justiça do Estado do Rio de Janeiro, Rio de Janeiro, n.67, abr./maio. 2006, p. 60.

${ }^{202}$ VICARI, Marcio Luiz Fogaça. Op. cit., p .215/216

${ }^{203}$ DINAMARCO, Cândido Rangel. A Reforma do Código de Processo Civil. São Paulo: Malheiros, 1996, p. 191.

${ }^{204}$ CARNEIRO, Athos Gusmão. Op. cit., p. 14

${ }^{205}$ A Comissão da nova reforma era constituída pelo Instituto Brasileiro de Direito Processual e pela Escola Nacional da Magistratura, e novamente coordenada pelos Ministros Sálvio de Figueiredo Teixeira e Athos Gusmão Carneiro. 
Nessa trilha, sobreveio a Lei $n^{\circ} 9.756 / 1998$ que, ampliando ainda mais os poderes do relator, conferiu ao artigo 557 do Código de Processo Civil a redação que hoje vigora ${ }^{206}$.

Primeiro, importante notar que enquanto a redação precedente fazia menção apenas a “tribunal superior" ${ }^{207}$, a Lei $\mathrm{n}^{\circ}$ 9.756/98 alterou o texto para que dele constasse também referência ao Supremo Tribunal Federal.

Além disso, a norma do art. 557 do Código de Processo Civil passou a prever entre os fundamentos que ensejam o julgamento do recurso pelo relator a contrariedade da tese jurídica que o fundamenta à jurisprudência dominante do tribunal competente para o julgamento, do Supremo Tribunal Federal ou de tribunal superior ${ }^{208}$. “Assim, para a decisão monocrática do relator, deixou de ser necessário que o entendimento da jurisprudência do tribunal, contrario à tese recursal, esteja sumulado, sendo suficiente que represente o pensamento dominante a seu respeito",209.

Também por força da Lei $\mathrm{n}^{\circ} 9.756 / 98$, que acrescentou o $\S 1^{\circ}-\mathrm{A}$, o legislador autorizou o relator a isoladamente dar provimento aos recursos, nos casos em que a decisão recorrida estiver em divergência com súmula ou com a jurisprudência dominante do Supremo Tribunal

\footnotetext{
${ }^{206}$ Art. 557. O relator negará seguimento a recurso manifestamente inadmissível, improcedente, prejudicado ou em confronto com súmula ou com jurisprudência dominante do respectivo tribunal, do Supremo Tribunal Federal, ou de Tribunal Superior.

$\S 1^{\circ}$-A Se a decisão recorrida estiver em manifesto confronto com súmula ou com jurisprudência dominante do Supremo Tribunal Federal, ou de Tribunal Superior, o relator poderá dar provimento ao recurso.

$\S 1^{\circ}$ Da decisão caberá agravo, no prazo de cinco dias, ao órgão competente para o julgamento do recurso, e, se não houver retratação, o relator apresentará o processo em mesa, proferindo voto; provido o agravo, o recurso terá seguimento.

$\S 2^{\circ}$ Quando manifestamente inadmissível ou infundado o agravo, o tribunal condenará o agravante a pagar ao agravado multa entre um e dez por cento do valor corrigido da causa, ficando a interposição de qualquer outro recurso condicionada ao depósito do respectivo valor.

${ }^{207}$ Para Pedro Luiz Pozza, no conceito de "tribunal superior" não se incluía o Supremo Tribunal Federal (no seu entender, tecnicamente, seriam tribunal superior apenas o STJ, o TSE, o TST e o STM), de modo que a interpretação literal do caput do art. 557 do CPC, na redação dada pela Lei n. 9.139/95, não permitiria sua aplicação quando a súmula invocada fosse da Corte Suprema. (POZZA, Pedro Luiz. Considerações sobre a lei 9.756/98. Ajuris, 75, p. 360) Ousamos discordar do autor já que "cuia licet quod est plus, licet utique quod est minus"; sendo o Supremo Tribunal Federal a Corte mais "alta" do pais, não ha razão para se afastar a aplicação de suas súmulas para que fosse autorizado o julgamento monocrático do recurso.

${ }^{208}$ CARNEIRO, Athos Gusmão. Op. cit., p. 18.

${ }^{209}$ FERNANDES, Sérgio Ricardo de Arruda. Op. cit., p. 60.
} 
Federal ou do Superior Tribunal de Justiça; o dispositivo nada diz com relação ao recurso fundado em orientação predominante do tribunal local.

Com relação à impugnação da decisão monocrática do relator, a Lei $n^{\circ}$ 9.756/98 manteve o prazo de 5 dias para interpor o recurso (agravo) e permitiu ao relator o exercício do juízo de retratação. Ademais, a antiga redação do artigo 557 estabelecia que o relator "pediria dia" para julgamento do agravo (i.e., incluiria o processo, previamente, na pauta de julgamento), enquanto que a Lei n. 9.756/98 determina que "o relator apresentará o processo em mesa, proferindo voto".

A nova reforma introduziu, ainda, novo regime sancionatório, prestigiando a atuação responsável dos litigantes no processo; por meio do $\S 2^{\circ}$ foi estabelecida multa de $1 \%$ a $10 \%$ do valor corrigido dado à causa para a parte que interpuser agravo manifestamente inadmissível ou infundado, sendo que seu recolhimento é condição para a interposição de novo recurso.

A nova redação dada ao artigo 557 do Código de Processo Civil pela Lei ${ }^{\circ}$ 9.756/1998 "tem como escopo desobstruir as pautas dos tribunais, a fim de que as ações e os recursos que realmente precisam ser julgados por Órgão Colegiado possam ser apreciados o quanto antes possível. Por essa razão, os recursos intempestivos, incabíveis, desertos e contrários à jurisprudência consolidada no tribunal de segundo grau ou nos tribunais superiores deverão ser julgados imediatamente pelo próprio relator, através de decisão singular, acarretando o tão desejado esvaziamento das pautas. Prestigiou-se, portanto, o princípio da economia processual e o princípio da celeridade processual, que norteiam o direito processual moderno",210.

${ }^{210}$ STJ, REsp 156.311-BA, $2^{\mathrm{a}}$ Turma, Rel. Min. Adhemar Maciel, j. 19.2.1998, DJ 16.3.1998, p. 192. 


\subsection{As propostas de alteração do artigo 557 do Código de Processo Civil}

$\mathrm{Na}$ exposição de motivos do "novo" Código ${ }^{211}$, os juristas responsáveis por sua elaboração afirmam que as sucessivas reformas operadas que incluíram alterações aos poucos, fizeram com que, naturalmente, ficasse enfraquecida a coesão entre as normas processuais, comprometendo a sua forma sistemática e a celeridade. Segundo seu entendimento, a preocupação em se preservar a forma sistemática das normas processuais, longe de ser meramente acadêmica, atenderia, sobretudo, a uma necessidade de caráter pragmático: obterse um grau mais intenso de funcionalidade.

Assim, explicam que na elaboração deste Anteprojeto de Código de Processo Civil, a principal preocupação dos trabalhos seria a de resolver os problemas cuja existência é unanimemente reconhecida na comunidade jurídica. Um dos exemplos, no entender da Comissão, seria o da complexidade do sistema recursal.

Conforme texto da Exposição de Motivos, os trabalhos da Comissão orientaram-se, precipuamente por cinco objetivos, quais sejam: “(i) estabelecer expressa e implicitamente verdadeira sintonia com a Constituição Federal; (ii) criar condições para que o juiz possa proferir decisão de forma mais rente à realidade fática subjacente à causa; (iii) simplificar, resolvendo problemas e reduzindo a complexidade de subsistemas, como, por exemplo, o recursal; (iv) dar todo o rendimento possível a cada processo em si mesmo considerado; e, (v) finalmente, sendo talvez este último objetivo parcialmente alcançado pela realização daqueles mencionados antes, imprimir maior grau de organicidade ao sistema, dando-lhe, assim, mais coesão",212.

No que toca às alterações do sistema recursal, afirma a Comissão na Exposição de Motivos que estas tiveram por objetivo simplificar e agilizar o processo, dando-lhe, simultaneamente, o maior rendimento possível.

\footnotetext{
211 BRASIL. Congresso Nacional. Senado Federal. Comissão de Juristas Responsável pela Elaboração de Anteprojeto de Código de Processo Civil. Código de Processo Civil: anteprojeto / Comissão de Juristas Responsável pela Elaboração de Anteprojeto de Código de Processo Civil. - Brasília: Senado Federal, Presidência, 2010.

${ }^{212}$ Idem.
} 
Os textos do Anteprojeto (artigo $853^{213}$ ) e do Projeto de Lei $\mathrm{n}^{\circ}$ 8.046/10 (artigo 858) preveem a alteração da redação do artigo 557 do Código de Processo Civil. Caso aprovado o Projeto de Lei n ${ }^{\circ}$ 8.046/10 tal como encaminhado à Câmara dos Deputados, o relator passará a poder (i) negar seguimento a recurso inadmissível, prejudicado ou que não tenha atacado especificamente os fundamentos da decisão ou sentença recorrida; (ii) negar provimento a recurso que contrariar súmula do Supremo Tribunal Federal, do Superior Tribunal de Justiça ou do próprio tribunal; acórdão proferido pelo Supremo Tribunal Federal ou pelo Superior Tribunal de Justiça em julgamento de casos repetitivos; entendimento firmado em incidente de resolução de demandas repetitivas ou de assunção de competência; e (iii) dar provimento ao recurso se a decisão recorrida contrariar súmula do Supremo Tribunal Federal, do Superior Tribunal de Justiça ou do próprio tribunal; acórdão proferido pelo Supremo Tribunal Federal, ou pelo Superior Tribunal de Justiça em julgamento de casos repetitivos; entendimento firmado em incidente de resolução de demandas repetitivas ou de assunção de competência.

O texto corrige antigos defeitos da redação, ao dispor que ao relator incumbe negar provimento (e não seguimento) a recurso que contrariar (e não confrontar) súmula e elimina a possibilidade de o relator negar/dar provimento a recurso contrário/conforme a jurisprudência dominante, encerrando o debate acerca da ambiguidade da expressão "jurisprudência dominante", constantemente criticada pela doutrina. Além disso, incentiva a valorização dos precedentes ao possibilitar o provimento ou desprovimento de recurso, conforme o caso,

\footnotetext{
${ }^{213}$ Art. 853. Incumbe ao relator:

(...)

III - negar seguimento a recurso inadmissível, prejudicado ou que afrontar:

a) súmula do Supremo Tribunal Federal, de tribunal superior ou do próprio tribunal;

b) decisão proferida pelo Supremo Tribunal Federal ou por tribunal superior em julgamento de casos repetitivos;

IV - dar provimento ao recurso se a decisão recorrida afrontar:

a) súmula do Supremo Tribunal Federal, de tribunal superior ou do próprio tribunal;

b) decisão proferida pelo Supremo Tribunal Federal ou por tribunal superior em julgamento de casos repetitivos; $\mathrm{V}$ - exercer outras atribuições estabelecidas nos regimentos internos dos tribunais.

$\S 1^{\circ}$ Da decisão proferida nos casos dos incisos III e IV caberá agravo interno, no prazo de quinze dias, ao órgão competente para o julgamento do recurso, e, se não houver retratação, o relator incluirá o recurso em pauta para julgamento.

$\S 2^{\circ}$ Quando manifestamente inadmissível o agravo interno, assim declarado em votação unânime, o tribunal condenará o agravante a pagar ao agravado multa fixada entre um e dez por cento do valor corrigido da causa, ficando a interposição de qualquer outro recurso condicionada ao depósito do respectivo valor.
} 
quando houver acórdão proferido em julgamento de casos repetitivos ou entendimento firmado em incidente de resolução de demandas repetitivas ou de assunção de competência.

O texto atual do anteprojeto diz incumbir ao relator, dentre outros, (i) não conhecer de recurso inadmissível, prejudicado ou que não tenha impugnado especificamente os fundamentos da decisão recorrida; (ii) negar provimento a recurso que for contrário a (ii.1) súmula do Supremo Tribunal Federal, do Superior Tribunal de Justiça ou do próprio tribunal; (ii.2) acórdão proferido pelo Supremo Tribunal Federal ou pelo Superior Tribunal de Justiça em julgamento de recursos repetitivos; e (ii.3) entendimento firmado em incidente de resolução de demandas repetitivas ou de assunção de competência; e (iii) dar provimento ao recurso, depois de facultada, quando for o caso, a apresentação de contrarrazões se a decisão recorrida for contrária a (iii.1) súmula do Supremo Tribunal Federal, do Superior Tribunal de Justiça ou do próprio tribunal; (iii.2) acórdão proferido pelo Supremo Tribunal Federal ou pelo Superior Tribunal de Justiça em julgamento de recursos repetitivos; e (iii.3) entendimento firmado em incidente de resolução de demandas repetitivas ou de assunção de competência. Além disso, o parágrafo único dispõe que antes de considerar inadmissível o recurso, o relator concederá o prazo de cinco dias ao recorrente para que seja sanado vício ou complementada a documentação exigível.

\section{A constitucionalidade do artigo 557 do Código de Processo Civil}

A constitucionalidade do art. 38 da Lei $\mathrm{n}^{\circ}$ 8.038/90, que influenciou o legislador a alterar a redação do art. 577 do Código de Processo Civil, já havia sido objeto de questionamento pela doutrina. Nelson Luiz Pinto afirmou à época que a Constituição Federal já previa remédio adequado em face de decisão que adotasse tese jurídica divergente de outro tribunal da federação, qual seja, o recurso especial. O autor aduziu, ainda, que a inconstitucionalidade do dispositivo decorria "do fato de, ao dispor a lei, que sempre que o recurso, especial ou extraordinário, contrarie súmula do Tribunal devera ser 'improvido' liminarmente, pelo relator (juízo de mérito), dela resulta solução praticamente equivalente à negativa de seguimento (admissibilidade) do recurso. Na verdade, está-se, com isto, impedindo que a decisão recorrida seja reexaminada e possivelmente reformada, em razão da 
existência de súmula do Tribunal no mesmo sentido, o que de certo modo equivale a condenar o recurso à improcedência." 214

A questão da inconstitucionalidade do art. 38 da Lei $n^{\circ} 8.038 / 90$ foi analisada pelo Supremo Tribunal Federal que, em julgamento plenário, aniquilou qualquer polêmica que pudesse vir a ser travada nesta seara ao decidir que "É legítima, sob o ponto de vista constitucional, a atribuição conferida ao Relator para arquivar ou negar seguimento a pedido ou recurso intempestivo, incabível ou improcedente e, ainda, quando contrariar a jurisprudência predominante do Tribunal ou for evidente a sua incompetência (RI/STF, art. 21, par 1.; Lei n. 8.038/90, art. 38), desde que, mediante recurso -- agravo regimental -- possam as decisões ser submetidas ao controle do colegiado". (MI-AgR n 375, Rel. Min. Carlos Velloso, Tribunal Pleno, DJ 15.5.1992) $)^{215}$.

O art. 557 do Código de Processo Civil também suscitou a questão da inconstitucionalidade. Para os defensores da tese de que aos órgãos colegiados cabe a análise dos recursos que lhes sejam destinados, como Izaías Batista de Araújo ${ }^{216}$, Hélio Rubens

\footnotetext{
${ }^{214}$ PINTO, Nelson Luiz. Recurso especial e recurso extraordinário - a Lei 8.038, de 28.5.90 e as alterações no Código de Processo Civil. Revista de Processo, n. 57, p. 123.

${ }^{215}$ Consta do voto o seguinte entendimento:

"Não ha duvida que compete ao Supremo Tribunal Federal, pelo seu Plenário, processar e julgar, originariamente, o mandado de injunção, nas hipóteses inscritas no art. 102, I, 'q', da Constituição Federal. Todavia, como bem disse o Sr. Ministro CELSO DE MELLO, no voto que proferiu por ocasião do julgamento da ADIn 531-6 (AgRg)-DF, a regra de competência da Corte 'não subtrai ao Relator da causa o poder de efetuar -enquanto responsável pela ordenação e direção do processo (RISTF, art. 21, I) - o controle prévio dos requisitos formais da fiscalização abstrata, o que inclui, dentre outras atribuições, o exame dos pressupostos processuais e das condições da própria ação direta" "

"A regra do art. $21, \S 1^{\circ}$, do RISTF que esta reproduzida no art. 38 , da Lei $n^{\circ} 8.038$ de 1990 , da ao relator competência que deflui do poder que é conferido ao Relator de dirigir e ordenar o processo. A regra de competência em apreço é legitima na medida em que poderão as decisões do Relator, no uso da competência inscrita no art. $21, \S 1^{\circ}$, do RISTF e art. 38 , da Lei 8.038 , ser submetidas ao controle do Plenário ou das Turmas mediante o agravo regimental, tal como ocorre no presente caso."

"No julgamento da ADIn n ${ }^{\circ}$ 531-6-DF, o Sr. Ministro CELSO DE MELLO lembrou que essa matéria já foi apreciada e decidida pela Corte Suprema na Rep. 1.299-GO, Relator o eminente Ministro CÉLIO BORJA, que no seu voto deixou expresso: 'Podem, portanto, os tribunais, através de norma regimental, atribuir competência própria e singular aos seus membros. Mas não podem declinara a favor deles a competência que a Constituição investiu nos próprios tribunais, como órgãos de deliberação coletiva. Sobretudo, não podem emprestar o atributo de decisão definitiva aos despachos dos seus membros (RTJ 119/980, 985)'”.

"Quer dizer, podem os tribunais atribuir competência aos seus membros, desde que as decisões tomadas por estes, solitariamente, possam ser, mediante recurso, submetidas ao controle do colegiado."

${ }^{216}$ ARAÚJO, Izaías Batista de. Do impedimento do Ministro Relator quando decide recurso com base no art. 38 da lei 8,038/90, Aplicação do art. 134, III do CPC. Revista dos Tribunais, Paulo, v.83, n.716, jun. 1995, p. 363.
} 
Ribeiro da Costa $^{217}$ e Marcos Afonso Borges ${ }^{218}$, o julgamento monocrático de recurso violaria o artigo 96, I da Constituição Federal e os princípios do duplo grau de jurisdição, do devido processo legal e da ampla defesa (art. 5, LV e LIV, da Constituição Federal). Os autores entendem que o vocábulo "tribunal", que consta dos artigos 102 e 105 da Constituição Federal, indica que o julgamento deva ser colegiado e que quando o recurso é decidido de forma monocrática, as partes são privadas do direito a memoriais, da sustentação oral e dos embargos de divergência ${ }^{219}$.

Esta posição já foi defendida, no passado, por Nelson Nery $\mathrm{Jr}^{220}$ (tendo, atualmente revisto seu entendimento ${ }^{221}$ ). $\mathrm{O}$ autor dizia que "os dispositivos legais que conferem poderes ao relator para decidir sobre a admissibilidade e o próprio mérito dos recursos extraordinário e especial (art. 38 da Lei 8.038/90 e CPC, art. 544, §2 e 545), são inconstitucionais por ferirem os princípios do direito de ação e duplo grau de jurisdição. Quando o constituinte cometeu ao STF e ao STJ o julgamento dos recursos extraordinário e especial, respectivamente, quis que o julgamento desses recursos fosse tomado por órgão colegiado, em atendimento ao princípio do duplo grau de jurisdição. Como o relator - juiz singular, monocrático - pode julgar o mérito dos recursos, decretando sua improcedência, estará frustrando a norma constitucional que determinou como competente para referido julgamento, os tribunais federais superiores (STF e STJ)".

\footnotetext{
${ }^{217}$ COSTA, Hélio Rubens Batista Ribeiro. A inconstitucionalidade da primeira parte do paragrafo 3, do artigo 544 do Código de Processo Civil e demais questões referente ao julgamento monocratico dos recursos constitucionais. Revista do Instituto dos Advogados de São Paulo, São Paulo, v.2, n.4, jul./dez. 1999, p. 118.

${ }^{218}$ BORGES, Marcos Afonso, apud CARVALHO, Fabiano. Op. cit., p. 43.

${ }^{219}$ Segundo Hélio Rubens Batista Ribeiro da Costa, “(...) impedido o litigante de sustentar oralmente suas contra razoes (...) ou mesmo de apresentar memoriais, notavelmente o enfraquecimento de seu direito constitucional da ampla e irrestrita defesa porque estar-se-ia prejudicando sobremaneira o contraditório, subtraindo-lhe importantes meios e mecanismos a seu dispor na legislação processual e no próprio Estatuto da Advocacia (Lei Federal 8.906, de 4.7.1994)" ( Op. cit., p. 118).

${ }^{220}$ Princípios do processo civil na Constituição Federal. 3 ed. São Paulo: RT, 1996, p. 165.

${ }^{221}$ Nelson Nery Jr e Rosa Maria Andrade Nery, Código de Processo Civil comentado, $2^{\mathrm{a}}$ ed., São Paulo: RT, 1996, p. 1.072, art. 557, nota 3. O autor diz que, "quando os art. 102, II e II, e 105, II e III, da CF, atribuem competência ao STF e ao STJ para o julgamento dos recursos extraordinário e especial, não diz expressamente a qual órgão do tribunal compete referido julgamento. Em sendo assim, é licito à lei ordinária conferir poderes ao relator para apreciar a admissibilidade e o próprio mérito daqueles recursos excepcionais, em decisão preliminar, cuja eficácia fica condicionada à não impugnação pela parte ou interessado".
} 
No entanto, prevaleceu na doutrina ${ }^{222}$ o entendimento de que as disposições do artigo 557 do Código de Processo Civil são constitucionais e não há ofensa ao duplo grau de jurisdição, na medida em que as decisões individuais do relator podem ser submetidas ao controle do órgão colegiado por intermédio de agravo previsto no $§ 1^{\circ}$ do dispositivo.

Com relação à possibilidade de a parte vencida interpor agravo ao órgão colegiado, Cândido Rangel Dinamarco asseverou que a medida "homenageia a garantia constitucional do devido processo legal, na medida em que põe limite ao poder do relator em julgamentos que em princípio pertencem aos órgãos colegiados; presta reverência também ao valor das garantias do juiz natural, porque os colegiados são o juiz natural dos recursos"223.

O debate acerca da constitucionalidade da norma foi mais uma vez sepultado pelo Supremo Tribunal Federal em julgamento plenário: "Tem legitimidade constitucional disposição regimental que confere ao relator competência para arquivar ou negar seguimento a pedido ou recurso, desde que as decisões possam ser submetidas ao controle do colegiado" (Agr. Emb. Div. Emb. Decl. Agr em AG n 151.354-3/MG, Pleno, Rel. Min. Néri da Silveira, j. 18.2.1999) $)^{224}$.

Ocorre que, como bem assentou Sérgio Cruz Arenhart ${ }^{225}$, é curiosa tal decisão. Isto porque, conquanto estabeleça a Lei Maior a competência dos tribunais para o julgamento dos recursos, não há nenhuma determinação no sentido de que os recursos devam ser obrigatoriamente julgados por órgãos colegiados: "Afinal, se efetivamente não há (como de fato é o que parece) qualquer determinação que imponha o julgamento de recursos por órgãos colegiados, então, fica sem sentido a advertência do julgado no sentido de que não existiria inconstitucionalidade quando houvesse a possibilidade de que a decisão do relator pudesse ser

${ }^{222}$ CARVALHO, Fabiano. Op. cit., p.46/47; SLAIBI FILHO, Nagib. Op. cit., p. 98; CAMBI, Accácio. Op. cit., p. 169; CARNEIRO, Athos Gusmão. Op. cit., p. 17

${ }^{223}$ DINAMARCO, Candido Rangel. O relator, a jurisprudência e os recursos. In: WAMBIER, Teresa Arruda Alvim (coord.); NERY JUNIOR, Nelson (coord.). Aspectos polêmicos e atuais dos recursos cíveis de acordo com a lei 9.756/98. São Paulo: Revista dos Tribunais, 1999. p.132.

${ }^{224}$ Mirna Cianci, com base no magistério de Nagib Slaibi Filho, defende que o precedente tem efeito vinculante, já que o artigo 97 da Constituição Federal contempla o principio da reserva de plenário, impedindo os órgãos fracionários de submeter a arguição incidental. CIANCI, Mirna. Op. cit., p105

${ }^{225}$ ARENHART, Sérgio Cruz. A nova postura do relator no julgamento dos recursos. Revista de Processo, São Paulo: Revista dos Tribunais, vol. 103, jul./set./2001, p. 39/41. 
revista pela corte. Ora, ou não existe óbice constitucional ao julgamento monocrático do recurso pelo relator, ou existe esta restrição (caso em que realmente não se poderia prescindir do reexame do julgamento, em qualquer hipótese, pelo colegiado original) e, mais que isto, a delegação desta função ofenderia, diretamente, a proibição constitucional, ainda que se previsse, desta atribuição, reexame da matéria pelo órgão originário (...)”.

Portando, inexistindo previsão constitucional que imponha o julgamento de recurso por órgãos colegiados, não é a possibilidade de interposição de um recurso com índole "controladora" que justifica a constitucionalidade do julgamento unipessoal. Como bem observou Fabiano Carvalho ${ }^{226}$, “a decisão unipessoal do relator é consumação normal e legal do pleno exercício de sua atividade cognitiva para prestar tutela jurisdicional, uma vez que a lei lhe atribuiu competência”. Assim, não existe nenhuma restrição a que se confira ao relator poderes para julgar, monocraticamente, qualquer espécie de recurso.

${ }^{226}$ CARVALHO, Fabiano. Op. cit., p. 47. 


\section{CAPÍTULO 5 - ANÁliSE dO ARTIGO 557 DO CÓDIGO DE PROCESSO CIVIL}

\section{As deficiências de redação do artigo 557 do Código de Processo Civil}

O artigo 557 do Código de Processo Civil concedeu ao relator os mesmos poderes conferidos ao colegiado: poder negar conhecimento ao recurso, inadmitindo-o; conhecendo-o, pode dar-lhe ou negar-lhe provimento ${ }^{227}$. Todavia, sua redação sofreu merecidas críticas, por parte da doutrina, em relação à forma e ao uso impróprio da palavra "confronto" e, sobretudo, pelo emprego de conceitos demasiadamente vagos ${ }^{228}$ (como "manifestamente" inadmissível, improcedente, prejudicado e "jurisprudência dominante").

O desprezo às regras da boa técnica legislativa salta aos olhos. $\mathrm{O}$ legislador brasileiro, imbuído de mania xenófila, pretendeu imitar a forma como o direito alienígena enumera as regras jurídicas, apondo letras à numeração dos artigos e parágrafos ${ }^{229}$. No caso do artigo 557 do Código de Processo Civil, o parágrafo incluído pela Lei $n^{\circ}$ 9.756/98 foi batizado de " $1^{\circ}-\mathrm{A}$ " e colocado antes do $\$ 1^{\circ 230}$. Conforme pondera Sérgio Cruz Arenhart, não há como entender por qual razão o legislador considerou que " $1{ }^{\circ}-\mathrm{A}$ " seria antecessor de " 1 " e por que desconsiderou a lógica na sequência fornecida secularmente pelos números ordinais ${ }^{231}$.

Mencione-se também o uso impróprio do termo "confronto" ("recurso em manifesto confronto com súmula ou com jurisprudência dominante"), em vez de conflito, contraste ou até mesmo contradição. São oportunas as palavras de Professor Barbosa Moreira sobre o tema: “o legislador dá a impressão de haver empregado palavra confronto no sentido de contraste,

\footnotetext{
${ }^{227}$ FERREIRA FILHO, Manoel Caetano. Apud. CUNHA, Eurípedes Brito. Op. cit., p. 35/36

${ }^{228}$ OLIVEIRA, Pedro Miranda de. Poderes do relator no agravo de instrumento: impossibilidade de provimento singular sem a oitiva da parte agravada. Revista Dialética de Direito Processual, São Paulo, n.81, p.89-98, dez. 2009, p. 90.

${ }^{229}$ Sérgio Cruz Arenhart lembra que a numeração dos parágrafos do art. 557 do Código mereceu a pena de Barbosa Moreira, para quem "nada se pode querer, realmente, de mais esdruxulo: no quesito 'originalidade', que tempos atrás valia pontos em concursos de fantasias carnavalescas, o texto faz jus, sem favor, à pontuação máxima". ARENHART, Sérgio cruz. Op. cit., p. 38.

${ }^{230}$ Tal técnica foi considerada por Barbosa Moreira como imperícia passível de inscrever-se em pauta puramente anedótica. (MOREIRA, José Carlos Barbosa. Reformas do CPC... Op. cit., p. 55)

${ }^{231}$ ARENHART, Sérgio Cruz. Op. cit., p. 39.
} 
oposição, contradição, conflito. Ora, confronto significa mera comparação. É óbvio que de confronto pode decorrer a conclusão de que as coisas confrontadas (isto é, comparadas) contrastam entre si, se opõem, se contradizem, conflitam uma com a outra, mas esse é apenas um dos resultados concebíveis" $" 232$.

A redação possui, ainda, defeitos graves que suscitam dificuldades nos planos doutrinário e prático.

É o caso da expressão “jurisprudência dominante”. A doutrina ainda não atingiu consenso quanto à fixação de sua extensão ${ }^{233}{ }^{234}$, já que a consideração deste ou daquele entendimento jurisprudencial como "dominante" depende de apreciação subjetiva do relator. E nunca é demais lembrar que, nos tribunais, podem e costumam ocorrer oscilações, de modo que ora prevalecera uma tese, ora a tese oposta ${ }^{235}$, sendo que em uma única sessão o tribunal pode alterar seu entendimento sobre o tema.

\subsection{O sentido das expressões "manifestamente" $e$ "manifesto"}

O artigo 557 do Código de Processo Civil diz caber julgamento monocrático do recurso que for manifestamente inadmissível, improcedente ou prejudicado (caput) e também quando a decisão recorrida estiver em manifesto confronto com súmula ou com jurisprudência dominante $\left(\S 1^{\circ}-\mathrm{A}\right)$. Estabelece, ainda, que agravo interposto contra a decisão singular enseja a cominação de multa quando manifestamente inadmissível ou infundado $\left(\$ 2^{\circ}\right)$. A dúvida que surge é: qual o alcance das expressões manifesto e manifestamente?

Conforme pondera Carreira Alvim, “um recurso 'inadmissível' não é o mesmo que um recurso 'manifestamente' inadmissível, e é sabido que a lei não usa palavras supérfluas.

\footnotetext{
${ }^{232}$ BARBOSA MOREIRA, José Carlos. Comentários... Op. cit.

${ }^{233}$ VIVEIROS, Estefânia. Op. cit., p. 63.

${ }^{234}$ As diversas tentativas de conceituação do que seria a jurisprudência dominante de que trata o artigo 557 do Código de Processo Civil serão analisadas em capitulo próprio.

${ }^{235}$ MOREIRA, José Carlos Barbosa. Reformas do CPC... Op. cit., p. 59
} 
Manifesto é a qualidade do que é claro, evidente, público, não comporta dúvida nem discussão razoável; 'manifestamente' é um modo como o recurso se apresenta em juízo"236.

Assim, por manifestamente deve-se entender aquela situação em que não há dúvidas da subsunção do caso concreto às hipóteses contempladas no artigo 557 do Código, sendo “evidente aos olhos do juízo (...) de que outro não seria o desfecho do recurso que não aquele pelo qual optou em sua analise singular"237.

O relator, ao analisar o caso concreto, percebe, desde logo e com facilidade, se ele deve ou não ser julgado monocraticamente ${ }^{238}$. Importante destacar que a cognição do relator não é superficial ou menos abrangente que a cognição que faria a turma julgadora; o advérbio manifestamente exige do relator a plena convicção de que pode proceder ao julgamento singular.

Disto decorre que a definição do que seja manifesto ou não depende, não raro, de avaliação subjetiva do magistrado. Isto porque, para um juiz, o recurso pode ter solução manifesta, enquanto que, para outro, de menor conhecimento naquela especifica área do direito, a resposta será outra ${ }^{239}$. Como bem pondera Cândido Rangel Dinamarco, “o legislador quis deixar ao prudente arbítrio do próprio Relator a opção entre julgar por si próprio, monocraticamente, ou encaminhar o caso ao colegiado. Naturalmente, essa opção dependerá sempre do grau de convicção do Relator, a quem competirá, com honestidade profissional, abster-se de julgar quando sentir que a matéria não é tão segura que legitime esses verdadeiros atalhos procedimentais instituídos pela lei",240.

\footnotetext{
${ }^{236}$ CARREIRA ALVIM, J.E. Ação monitoria e temas polêmicos da reforma processual. $3^{\mathrm{a}}$ ed. Belo Horizonte: Del Rey, 2001, p. 130.

${ }^{237}$ CIANCI, Mirna. Op. cit., p113. Nagib Slaibi Filho leciona que "tais expressões exigem do aplicador do Direito a percepção, certamente só possível no caso concreto, de grau de intensidade ou valoração do juízo tais que conduzam a, desde logo, dar acolhimento ao recurso ou the negar seguimento". (Op. cit., p. 104).

${ }^{238}$ Idem, p. 104

${ }^{239}$ Para Barbosa Moreira, “o 'manifestamente' pretende assumir aqui - à semelhança do que se da noutros textos - sentido restritivo, que todavia pode acabar por não ter grande alcance pratico: se ao relator pareceu enquadrarse o recurso numa das classes arroladas, é claro que, para ele, se fez 'manifesta' a inadmissibilidade, ou a improcedência, e assim por diante". (Comentários... Op. cit.).

${ }^{240}$ DINAMARCO, Candido Rangel. O relator, a jurisprudência e os recursos. In: WAMBIER, Teresa Arruda Alvim (coord.); NERY JUNIOR, Nelson (coord.). Aspectos polêmicos e atuais dos recursos cíveis de acordo com a lei 9.756/98. São Paulo: Revista dos Tribunais, 1999. p.132.
} 
Às mesmas conclusões chega Barbosa Moreira, verbis: "Valerá o advérbio, em todo caso, como recomendação aos relatores para que exercitem com comedimento a atribuição que se lhes defere, abstendo-se, por exemplo, de negar desde logo seguimento ao recurso sempre que, a despeito da opinião pessoal, por hipótese já formada, a questão se apresente passível de duvida ou controvérsia, de fato ou de direito" ${ }^{241}$.

Assim, se parecer duvidoso ao relator o enquadramento do recurso em uma das classes do art. 557, deverá abster-se de pronunciar-se individualmente e submeter o recurso à cognição do colegiado ${ }^{242}$. Na visão de Teresa Arruda Alvim Wambier, "todas estas situações que autorizam o relator a atuar no caso do art. 557, caput e parágrafo $1^{\circ}$, devem ser evidentes ou manifestas. A evidência permeia todo o artigo 557, caput e paragrafo $1^{\circ}$, sem o que o relator deverá, pura e simplesmente, admitir o recurso e submeter-lhe o mérito ao julgamento do órgão colegiado" ${ }^{243}$.

\subsection{O sentido da expressão "negar seguimento"}

Diz ainda o artigo 557 que o relator "negará seguimento" a recurso nos casos em que especifica. Na sofrível redação do caput do art. 557, a expressão negar seguimento foi empregada para permitir ao relator o não-conhecimento do recurso inadmissível e o

${ }^{241}$ BARBOSA MOREIRA, José Carlos. Comentários...Op. cit.

${ }^{242}$ CARVALHO, Fabiano. Op. cit., p. 85. Na visão de Sérgio Cruz Arenhart, " as causas de descabimento do recurso são questões de pressupostos recursais (e, portanto, questões de direito), sendo todas as situações evidentes. $\mathrm{O}$ mesmo seria possível dizer em relação aos casos de conflito do julgado recorrido à sumula de tribunal (ou ainda de sua adequação a esta sumula); também aqui a questão sempre ha de mostrar-se manifesta, ou porque se verifica a ofensa à sumula, ou porque, ao contrario, não ocorre esta divergência. Em todos estes casos, a situação será manifesta e não será possível apontar caso em que esta resposta evidente não se verifique de pronto. A menção, portanto, à "manifesta improcedência" (e seus semelhantes) deveria ser retirada do texto, a fim de impedir interpretações infelizes sobre a incidência da regra. (...). Em verdade, a locução "manifesta", presente na redação do artigo, apenas pode significar algo nos casos de procedência ou improcedência, em que esta evidencia será revelada exatamente pela existência de contraste do recurso com sumula ou jurisprudência dominante do próprio tribunal ou dos tribunais superiores ou, ainda, contraste da decisão recorrida com sumula ou jurisprudência dos tribunais superiores (exclusivamente). Caso não haja este contraste (do recurso ou da decisão recorrida) com jurisprudência dominante ou sumula destes tribunais, o exame do recurso não poderá, em semelhantes casos (de sua analise de mérito), implicar julgamento exclusivo pelo relator, devendo ser submetido à consideração do órgão colegiado competente”. (Op. cit., p. 45).

${ }^{243}$ WAMBIER, Teresa Arruda Alvim. Os agravos no CPC brasileiro. São Paulo: RT, 2006, p. 431. 
desprovimento daquele manifestamente improcedente ou contrário à sumula ou jurisprudência dominante $^{244245}$.

A doutrina, ao procurar definir o conceito da locução "negar seguimento", dividiu-se em duas correntes. A primeira sustenta que nos casos de improcedência e de contrariedade à súmula ou jurisprudência dominante, o relator efetua análise do mérito do recurso, de modo que não há negativa de "seguimento", mas de provimento. Por todos, Athos Gusmão Carneiro, para quem "o relator não apenas deixa de encaminhar o recurso ao órgão colegiado ao qual em princípio é dirigido, mas declara que não procede a própria pretensão recursal, decidindo ele, monocraticamente, com a mesma eficácia e amplitude de que se revestiria a decisão colegiada" 246 .

Já a segunda corrente defende que a locução "negar seguimento" abrange o desprovimento do recurso e o juízo negativo de admissibilidade, uma vez que não permite "a continuidade de um recurso sem condições de ser levado a julgamento colegiado. Significa dizer que, dado seu enquadramento em uma das categorias do caput do art. 557 do CPC, o recurso terá seu caminho interrompido por meio de decisão individual do relator" ${ }^{247}$.

Segundo Cândido Rangel Dinamarco, "negar seguimento é uma locução de grande envergadura, abrangendo hipóteses de recursos desmerecedores de conhecimento, porque lhes falta algum pressuposto de admissibilidade, e recursos desmerecedores de provimento, porque desamparados pelo direito, pela jurisprudência ou pela prova. No art. 557, portanto, negar seguimento é impedir que o recurso siga para câmara ou turma, em todas hipóteses nas quais ele seja claramente fadado ao insucesso (recursos manifestamente inadmissíveis ou infundados) $)^{\text {248 }}$.

Athos Gusmão Carneiro ${ }^{249}$, por sua vez, alega que não se cuida, a rigor, de negativa de

\footnotetext{
${ }^{244}$ OLIVEIRA, Pedro Miranda de. Op. cit., p. 90.

${ }^{245}$ Note-se que o legislador empregou corretamente a expressão "dar provimento" no § $1^{\circ}$-A do artigo 557.

${ }^{246}$ CARNEIRO, Athos Gusmão. Op. cit., p. 17.

${ }^{247}$ CARVALHO, Fabiano. Op. cit., p. 87/88

${ }^{248}$ DINAMARCO, Candido Rangel. O relator... Op. cit., p.132.

${ }^{249}$ CARNEIRO, Athos Gusmão. Op. cit., p. 17.
} 
"seguimento" ao recurso, mas negativa de "provimento", eis que o relator não apenas deixa de encaminhar o recurso ao órgão colegiado ao qual em princípio é dirigido, mas declara que não procede a própria pretensão recursal, decidindo ele, monocraticamente, com a mesma eficácia e amplitude de que se revestiria a decisão colegiada.

Disto conclui-se que a expressão "negar seguimento" empregada pelo caput do artigo 557 do Código de Processo Civil compreende o "não conhecimento" do recurso inadmissível ou prejudicado (admissibilidade) e o "não provimento" de recurso manifestamente improcedente ou contrário a súmula ou jurisprudência dominante (análise de mérito). Como se vê, o legislador utilizou inadequadamente a expressão "negar seguimento" ao se referir à análise do mérito recursal, quando o correto seria negar provimento, eis que o relator não apenas deixa de encaminhar o recurso ao Órgão Colegiado ao qual em princípio é dirigido, mas declara que não procede a própria pretensão recursal ${ }^{250}$.

\section{Recurso manifestamente inadmissível}

O órgão judicial, antes de apreciar o mérito da pretensão recursal, verifica se o recurso preenche as condições de admissibilidade, quais sejam, o cabimento, a legitimidade para recorrer e o interesse em recorrer (chamados pressupostos intrínsecos) e a tempestividade, a regularidade formal, a inexistência de fato impeditivo ou extintivo do ônus de recorrer e o preparo (chamados pressupostos extrínsecos) ${ }^{251}{ }^{252}$. A ausência de um dos requisitos de admissibilidade cria óbice para análise do mérito do recurso pelo órgão judicial.

Assim, quando os requisitos exigidos em lei são observados pelo recorrente, diz-se que o juízo de admissibilidade é positivo; o órgão judicial competente admite o recurso e aprecia o seu mérito. Por outro lado, quando faltar ao recurso interposto um ou mais requisitos gerais de

\footnotetext{
${ }^{250}$ CARNEIRO, Athos Gusmão. Op. cit., p. 17

${ }^{251}$ CAMBI, Accácio. Op. cit., p. 166

252 Mencione-se que ha casos em que a lei pode exigir a observância de pressupostos específicos de admissibilidade. Por exemplo, nos embargos infringentes, exige-se que o acordão recorrido tenha sido proferido por maioria de votos, em julgamento apelação ou ação rescisória. No agravo de instrumento, o recorrente é obrigado a efetuar os traslados das peças obrigatórias listadas no Código de Processo Civil. (CARNEIRO, Athos Gusmão. Op. cit., p. 16)
} 
admissibilidade, o juízo de admissibilidade é negativo e o órgão judicial abstém-se de examinar seu mérito ${ }^{253}$.

O recurso é inadmissível, por exemplo, quando se impugna ato processual que não constitui decisão ou quando o recorrente não possui interesse recursal, como nos casos em que não houve sucumbência ou prejuízo ${ }^{254}$.

O artigo 557 do Código de Processo Civil autoriza o relator a negar seguimento a recurso manifestamente inadmissível ${ }^{255}$, que deve ser entendido como aquele que não atende a algum ou alguns dos pressupostos genéricos e/ou específicos de admissibilidade de forma evidente $^{256}$, não existindo divergência doutrinária ou jurisprudencial acerca do descumprimento do pressuposto de admissibilidade descumprido. Nas palavras de Cândido Rangel Dinamarco, "ser manifesta a inadmissibilidade significa que ela é perceptível sem maiores esforços e sem a necessidade de indagações mais profundas ou tomadas de posição em matéria controvertida" 257 .

É o caso, por exemplo, de recurso apresentado após o término do respectivo prazo de interposição $^{258}$, de deserção decorrente do recolhimento do preparo após a interposição do apelo, ainda que dentro do prazo recursal ${ }^{259}$, de recurso especial interposto em face de decisão que declarou incidentalmente a inconstitucionalidade de lei federal ${ }^{260}$ e de agravo de

\footnotetext{
${ }^{253}$ VIVEIROS, Estefânia. Op. cit., p.68/69.

${ }^{254}$ SLAIBI FILHO, Nagib. Op. cit., p.104.

255 Interessante notar, como lembra Barbosa Moreira que o art. 38 da Lei $n^{\circ}$ 8.038/90 não falava em recurso “inadmissível”, mas em recurso "intempestivo" e em recurso "incabível”. A redação da Lei n 9.139/95 foi mais primorosa, ao não deixar dúvida de que as disposições do artigo 557 do Código eram aplicáveis em qualquer caso de inadmissibilidade (deserção, falta de legitimidade ou de interesse em recorrer etc.)". (Comentários... Op. cit.).

${ }^{256}$ CARNEIRO, Athos Gusmão. Op. cit., p. 15

${ }^{257}$ DINAMARCO, Cândido Rangel. A Reforma da Reforma. São Paulo: Malheiros, 2002, p. 185.

${ }^{258}$ Ao reverso do que ocorre nos casos de recurso supertempestivo, isto é, aquele interposto antes do inicio do prazo de interposição, havendo divergências doutrinarias e jurisprudenciais com relação a sua tempestividade e, portanto, admissibilidade.

${ }^{259}$ STJ, AgRg no REsp n ${ }^{\circ}$ 1.116.184-PR, 3a Turma, Rel. Min. Vasco Della Giustina, j. 17.8.2010, DJe 25.8.2010 e STJ, AgRg no AI no 703.004-RS, 3a Turma, Rel. Min. Sidnei Beneti, j. 18.9.2008, DJe 3.10.2008.

${ }^{260}$ STJ, AgRg no REsp no 360.994-SC, 6a Turma, Rel. Min. Hamilton Carvalhido, j. 16.4.2002, DJ 9.9.2002.
} 
instrumento desacompanhado de peça obrigatória (artigo 527, caput, do Código de Processo Civil) ${ }^{261262}$.

Quando o relator obsta o recurso sob o fundamento de que este é "manifestamente inadmissível", a análise deve se restringir ao exame dos pressupostos genéricos ou específicos, intrínsecos ou extrínsecos, de admissibilidade, mas sempre ao largo do exame de mérito ${ }^{263}$.

\section{Recurso manifestamente prejudicado}

Outra hipótese prevista no artigo 557 do Código de Processo Civil para julgamento monocrático é o caso de recurso manifestamente prejudicado.

Considera-se prejudicado o recurso quando ocorre fato superveniente à sua interposição que faz com que a impugnação perca seu objeto ${ }^{264}$. Como a pretensão fica sem conteúdo e eventual novo provimento jurisdicional em sede de recurso não proporcionaria à parte proveito ou utilidade, impõe-se o não conhecimento do recurso por falta superveniente de interesse recursal ${ }^{265}$.

Nas palavras de Barbosa Moreira, recurso prejudicado é aquele que perde o objeto "e, por conseguinte, cai no vazio o pedido de reforma ou anulação: v.g., se o juiz a quo reforma in totum a decisão agravada, prejudicado fica o agravo",266.

O recurso manifestamente prejudicado, por sua vez, é aquele em que a perda do objeto decorre de aspecto fático incontroverso e que a desnecessidade de seguimento resulta

\footnotetext{
${ }^{261}$ Convém lembrar, como faz Fabiano Carvalho, que o agravo de instrumento é inadmissível quando não for trasladada peça obrigatória. Um agravo que não seja instruído com peça facultativa pode ser considerado caso de manifesta improcedência, mas nunca de manifesta inadmissibilidade. ( Op. cit., p. 94).

${ }^{262}$ Athos Gusmão Carneiro lembra que, com relação aos demais recursos, ha posição doutrinaria que defende o máximo aproveitamento dos atos processuais praticados e o combate ao formalismo exacerbado, ensejando a concessão de prazo razoável para que seja apresentado o documento ou peça processual faltante. (Op. cit., p. 16). ${ }^{263}$ CIANCI, Mirna. Op. cit., p. 108

${ }^{264}$ CARVALHO, Fabiano. Op. cit., p.102. No mesmo sentido, SLAIBI FILHO, Nagib. Op. cit., p. 104.

${ }^{265}$ CAMBI, Accácio. Op. cit., p. 166

${ }^{266}$ BARBOSA MOREIRA, José Carlos. Comentários... Op. cit.
} 
absolutamente evidente ${ }^{267}$. No entanto, se a ocorrência da prejudicialidade for suscetível de controvérsia, convirá ao relator abster-se de pronunciá-la monocraticamente, cumprindo-lhe levar a questão à apreciação do colegiado ${ }^{268}$.

Exemplos de recurso manifestamente prejudicado são aqueles que versam sobre a validade do ato administrativo que acaba sendo revogado pela autoridade que o expedira ou aqueles interpostos em processo no qual as partes chegam a acordo sobre a questão discutida em juízo. De igual forma, nos termos do artigo 529 do Código de Processo Civil, considera-se manifestamente prejudicado o agravo se o juízo a quo reformar inteiramente a decisão recorrida $^{269}$. Por fim, mencione-se a hipótese de ação cautelar com o fim de ser atribuído efeito suspensivo a recurso especial, cujo processamento é inviabilizado caso o recurso seja julgado $^{270}$.

\section{Recurso manifestamente improcedente}

Outra hipótese contemplada pelo artigo 557 do Código de Processo Civil para que o relator negue seguimento a recurso é a daquele considerado "manifestamente improcedente". Como já analisado anteriormente, doutrina e jurisprudência criticam a imprecisão da locução "manifesta improcedência" e travam intenso debate acerca de seu significado e alcance.

Cândido Rangel Dinamarco afirma que "a improcedência de um recurso é a desconformidade entre a pretensão dirigida pelo recorrente ao tribunal e a ordem jurídica. Ela ocorre quando o recorrente pleitear contra lei expressa, ou contra a interpretação consagrada e pacificada de determinado texto legal, ou contra a prova produzida nos autos etc.”.

${ }^{267}$ CIANCI, Mirna. Op. cit., p. 109.

${ }^{268}$ CARNEIRO, Athos Gusmão. Op. cit., p. 16.

${ }^{269}$ Art. 529. Se o juiz comunicar que reformou inteiramente a decisão, o relator considerará prejudicado o agravo.

${ }^{270}$ STJ, AgRg na MC nº 18.042-RJ, 4a Turma, Rel. Min. Joao Otavio de Noronha, j. 9.8.2011, DJe: 19.8.2011 
Também Pontes de Miranda ${ }^{271}$ trouxe reflexões sobre a questão, asseverando que "essa improcedência manifesta ocorre nos casos em que a norma jurídica aplicável foi induvidosa contrária ao recorrente, na interpretação que a ela dão os tribunais e a doutrina. A controvérsia doutrinária sobre a norma, tal como aplicada pela decisão recorrida, exclui a possibilidade de indeferimento. A doutrina e os julgados dos artigos 17, I, e 485, V contribuem para se alcançar o conceito de improcedência manifesta, que será a situação ostensivamente determinante do desprovimento do recurso.”.

Para Sérgio Cruz Arenhart ${ }^{272}$ e Athos Gusmão Carneiro ${ }^{273}$, a expressão manifesta improcedência diz respeito aos casos de confronto com súmula ou jurisprudência dominante. Nas palavras do Ministro do Superior Tribunal de Justiça, “o exame, em juízo de deliberação, abrangerá igualmente o mérito do recurso, ao qual deve ser negado seguimento quando manifestamente improcedente, ou seja, quando a tese do recurso for, claramente, contrária a remansoso entendimento do tribunal de destino, ou de tribunal superior, a respeito da matéria".

Luiz Guilherme Marinoni ${ }^{274}$ lembra que também hão de ser considerados manifestamente improcedentes os recursos que insistam em negar a veracidade de fatos que não foram objeto de contestação, notórios, confessados e/ou documentalmente comprovados.

Para Sérgio Bermudes ${ }^{275}$, o recurso há de ser reputado manifestamente improcedente “se, no sentido da decisão recorrida, a jurisprudência estiver assentada ou se, a toda evidência

\footnotetext{
${ }^{271}$ CUNHA, Euripedes Brito. Despacho/Decisão do Relator - natureza jurídica - possibilidade de desconstituição por via rescisória. Revista Síntese de Direito Civil e Processual Civil. Ano III, n. 18, p. 33-36, jul./ago. 2002, p. 35.

${ }^{272}$ ARENHART, Sérgio Cruz. A nova postura do relator no julgamento dos recursos. Revista de Processo, São Paulo: Revista dos Tribunais, vol. 103, jul./set./2001, p. 97. Para o autor, a locução "manifestamente improcedente" "apenas pode significar algo nos casos de procedência ou improcedência em que esta evidencia sera revelada exatamente pela existência do contraste do recurso com sumula ou jurisprudência dominante do próprio tribunal ou dos tribunais superiores...".

${ }^{273}$ O Novo Recurso de Agravo e Outros Estudos. $4^{\text {a }}$ ed. Rio de Janeiro: Forense 1997, p. 78

${ }^{274}$ Tutela Antecipatória, Julgamento Antecipado e Execução Imediata da Sentença. $4^{\mathrm{a}}{ }^{\mathrm{e}}$ ed., São Paulo: Editora Revista dos Tribunais, 2000, p. 171.

${ }^{275}$ Apud, FERREIRA FILHO, Manoel Caetano. O indeferimento liminar do agravo de instrumento pelo relator. Revista de Processo. V. 69, ano 18, p. 230 233, jan./mar. 1993, p.232.
} 
a decisão recorrida se tiver limitado à aplicação de norma legal". Mirna Cianci ${ }^{276}$ ressalva que a consideração acerca da "manifesta improcedência" deve ter em conta "a postura do colegiado a que corresponde o relator e não aquela dominante em outros tribunais, ao passo que a possibilidade de negar seguimento a recurso tirado em confronto com "súmula ou jurisprudência dominante" deverá ter espeque no entendimento dos tribunais superiores ou do tribunal local, seja ou não coincidente com a postura da turma recursal a que pertence o relator".

Em monografia sobre o tema, Fabiano Carvalho defende que nem sempre um recurso manifestamente improcedente é contrário à súmula ou à jurisprudência dominante; aduz que manifestamente improcedente é o recurso "que carece de fundamento no mérito, isto é, 'quando infundados os motivos por que se impugna a decisão recorrida",277 278 . E ressalva que, havendo controvérsia em sede doutrinária e/ou jurisprudencial sobre o tema objeto do recurso, não deverá o relator julgar antecipadamente o recurso, por meio de decisão unipessoal sem a participação do órgão coletivo, já que a polêmica sobre determinada tese retiraria do recurso a condição de manifestamente improcedente ${ }^{279}$.

Manoel Caetano Ferreira Filho também defende que a hipótese de improcedência está relacionada com o mérito recursal, e questiona a redação do dispositivo por entender que a expressão "manifestamente improcedente" sugere a ideia de mérito enquanto que o vocábulo “indeferir" mais se adequa à inadmissibilidade do recurso ${ }^{280}$. E questiona se o relator poderia indeferir o agravo quando o considerar inadmissível e, também, por entendê-lo, no mérito, infundado (improcedente) ou apenas em uma destas hipóteses.

\footnotetext{
${ }^{276}$ CIANCI, Mirna. A lei 9.756/1998 (CPC, artigos 544, par. $3^{\circ}$ e 557, pars. $1^{\circ}$ a $3^{\circ}$ ) e a ampliação dos poderes do relator, dez anos depois. Revista Brasileira de Direito Processual RDBPro. ano 16, n. 61, jan./mar. 2008, Belo Horizonte: Ed. Fórum, p..111.

${ }^{277}$ Poderes do relator nos recursos: art. 557 do CPC. São Paulo: Saraiva, 2008, p.98.

${ }^{278}$ Mencione-se, ainda, os entendimentos de Estefânia Viveiros, para quem é improcedente "o recurso que, tratando de matéria de direito, volta contra entendimento pacificado do tribunal, ainda que nao sumulado". 17.166; de _, que assevera ser o recurso manifestamente improcedente (...) quando infundados os motivos pelos quais se impugna a decisão recorrida. (Agravo Interno no Superior Tribunal de Justiça e ampliação dos podres do relator. Universitas/jus. $\mathrm{n}^{\mathrm{o}}$ 7, p. 76)

${ }^{279}$ Poderes do relator nos recursos: art. 557 do CPC. São Paulo: Saraiva, 2008. p.100.

${ }^{280}$ FERREIRA FILHO, Manoel Caetano. O indeferimento liminar do agravo de instrumento pelo relator. Revista de Processo. V. 69, ano 18, jan./mar. 1993, p. 230.
} 
Ao analisar a questão, Teresa Arruda Alvim Pinto ${ }^{281}$ defende que, nesta hipótese, cabe ao relator realizar o juízo de mérito e assevera que o julgador não poderia manifestar-se, exclusivamente, para inadmitir o recurso, embora ressalve o argumento no sentido de que quem pode mais pode o menos, de modo que o relator poderia concluir pela inadmissibilidade de recurso julgado "manifestamente improcedente".

Sérgio Bermudes ${ }^{282}$ também se manifestou a respeito do tema e concluiu que, ao falar em manifesta improcedência, o artigo procurou dar ao relator a faculdade de indeferir tanto o recurso que não preencha os requisitos necessários a um pronunciamento de mérito, quanto aquele que, atendendo a esses pressupostos, não tenha possibilidade de vir a ser provido.

Ainda sobre o tema, Luiz Rodrigues Wambier"283 infere que "não fosse a inclusão da possibilidade de desprovimento do recurso - juízo de mérito, portanto - que se infere do uso do vocábulo improcedente, não haveria dúvida de que os poderes do relator se referem ao exercício do juízo de admissibilidade. De fato, pode o relator negar seguimento a recurso que se mostre inviável do ponto de vista de seus requisitos intrínsecos ou extrínsecos. Estes últimos, de natureza formal, referem-se ao preparo (isto é, ao pagamento) das custas relativas ao recurso, à tempestividade (...) e à regularidade relativa ao ato de recorrer, nos termos do que dispõem os arts. 514, 523 e 541 do CPC. Os requisitos intrínsecos dizem respeito à recorribilidade da mesma e são: o cabimento do recurso interposto pela parte, a legitimidade e o interesse do recorrente e a ausência de fatos que o impeçam de recorrer".

Por fim, nos casos em que o relator, ao pronunciar-se isoladamente, analisar o mérito recursal e concluir que as razões expostas pela parte são manifestamente improcedentes, importante ressaltar que ocorrerá a substituição de que cuida o art. 512 do CPC, no que tiver sido objeto de impugnação ${ }^{284}$.

\footnotetext{
${ }^{281}$ Apud, FERREIRA FILHO, Manoel Caetano. O indeferimento liminar do agravo de instrumento pelo relator. Revista de Processo. V. 69, ano 18, p. 231

${ }^{282}$ Idem.

${ }^{283}$ WAMBIER, Luiz Rodrigues. Uma proposta em torno do conceito de jurisprudência dominante. Revista de Processo. N. 100, ano 25, p. 81-86, out./dez 2000. Editora Revista dos Tribunais, p. 81.

${ }^{284}$ CARVALHO, Fabiano. Poderes do relator nos recursos: art. 557 do CPC. São Paulo: Saraiva, 2008, p.101.
} 


\section{Recurso em manifesto "confronto" com súmula}

$\mathrm{O}$ caput do art. 557 do CPC autoriza o relator a negar seguimento a recurso em "confronto" com súmula ou jurisprudência do respectivo tribunal, do Supremo Tribunal Federal ou de Tribunal Superior.

Podemos conceituar súmula como sendo o substrato do entendimento dominante de determinado tribunal a respeito da exegese e da aplicabilidade de normas legais em dado contexto histórico-social-politico $^{285}$. A súmula não tem feição nem força de lei e não pode ser considerada sucedâneo de norma legal.

A criação de súmulas tem por fim precípuo indicar a orientação do tribunal de modo a assegurar a uniformidade da jurisprudência, conferindo aos jurisdicionados uma expectativa de um julgamento previsível, já que pessoas em situações absolutamente idênticas não sofrerão efeitos de decisões completamente diferentes ${ }^{286} 287$.

Conforme Calamandrei ${ }^{288}$, "Uniformità del diritto non vuol dire immobilità del diritto, il quale, como tutte le manifestazione dello spirito umano, si svolge ininterrottamente attraverso un continuo divenire. Il principio dela uniformità del diritto obiettivo si deve pertanto inevitabilmente riportare a un determinato momento storico".

A despeito de não possuírem força de lei, as súmulas possuem grande efeito persuasivo sobre a formação e convencimento dos magistrados das instâncias inferiores ao apreciar

\footnotetext{
${ }^{285}$ Para Sérgio Bermudes "por súmula se haverá de entender não só a de que trata o art. 479 do CPC, mas qualquer enunciado que condense a jurisprudência predominante de um tribunal, editado em consonância com suas normas internas". - FC.114

${ }^{286}$ (Tereza Arruda Alvim Wambier “Sumula vinculante: desastre ou solução?”, RePro, 98, pag. 297). FC.106.rodape

${ }^{287}$ Para Alfredo Buzaid "a sumula é estabelecida não para impor cega obediência ao primado da exegese, estancando, desvanecendo ou estiolando o espirito criador dos juristas em busca de formulas novas que atendam ao objetivo da Justiça. A sua finalidade é por um clima de segurança na ordem jurídica, sem a qual fenecessem as esperanças na administração da Justiça". E complementa: "Seguir uma orientação uniforme é um bem para a estabilidade da ordem jurídica. Inspira confiança, guarda acatamento aos órgãos superiores da Justiça e mantem a autoridade". BUZAID, Alfredo. Da uniformização da jurisprudência. Boletim da Faculdade de Direito da Universidade de Coimbra, n.58, p.127.

${ }^{288}$ La cassazione civile, vol. II, p. 51/52.
} 
demanda nova. Conforme aduz Ellen Gracie Northfleet 289 "tal exercício, conjugado com a análise detalhada dos fatos da causa, da legislação aplicável e dos subsídios oferecidos pela produção doutrinária, conduz à prolação de sentenças densas de conteúdo, em que a decisão do litígio encontra embasamento seguro e as probabilidades de reforma se reduzem consideravelmente".

A redação do dispositivo sofreu severas críticas da doutrina por conta da expressão “contrariar", cabendo a Barbosa Moreira ${ }^{290}$ a síntese: "a rigor, o que pode contrariar súmula, pondo-se em contraste (não 'em confronto') com qualquer das proposições nela incluídas, é a tese jurídica sustentada pelo recorrente, não o recurso em si”. De fato, o legislador utilizou-se, impropriamente, da palavra "confronto". Confronto, na verdade, quer significar comparar, fazer face mutuamente. Melhor seria utilizar a palavra "contraste", "oposição", "contrariedade". Assim, ao recurso que estiver em contraste, oposição ou contrariedade com a tese jurídica sintetizada na súmula do tribunal o relator negará seguimento.”.

As críticas voltam-se, também, à imprecisão da expressão "tribunal superior", sendo questionado se abrangeria unicamente o Supremo Tribunal Federal e o Superior Tribunal de Justiça ou também outros tribunais como o Tribunal Superior do Trabalho e o Tribunal Superior Eleitoral.

Cândido Rangel Dinamarco manifestou o entendimento de que "tribunal superior" alude exclusivamente ao Superior Tribunal de Justiça tendo em vista que essa Corte representa o único tribunal superior com competência para causas regidas pelo direito processual civil comum $^{291}$. Fabiano Carvalho ${ }^{292}$ discorda do entendimento tendo em vista ser possível que o relator julgue individualmente recursos vinculados a outros campos do direito como criminal, trabalhista, eleitoral, em que o Código de Processo Civil tem aplicabilidade subsidiária. Nesses caos, outros órgãos individuais de outros tribunais.

\footnotetext{
${ }^{289}$ NORPHFLEET, Ellen Gracie. A força vinculante e do precedente judicial. University of Baltimore, jun/1998.

${ }^{290}$ Comentários ao Código de Processo Civil, Lei $n^{\circ}$ 5.869, de 11 de janeiro de 1973: art. 476 a 565, vol. V. Rio de Janeiro: Editora Forense, 2008, p. 662.

${ }^{291}$ O relator, a jurisprudência e os recursos. In: WAMBIER, Teresa Arruda Alvim (coord.); NERY JUNIOR, Nelson (coord.). Aspectos polêmicos e atuais dos recursos cíveis de acordo com a lei 9.756/98. São Paulo: Revista dos Tribunais, 1999. p.131.

${ }^{292}$ CARVALHO, Fabiano. Poderes do relator nos recursos: art. 557 do CPC. São Paulo: Saraiva, 2008, p. 113
} 
Novamente trazemos à colação o posicionamento de Barbosa Moreira ${ }^{293}$, para quem a expressão deve ser entendida "como referente a tribunal que, em linha de princípio, possa ainda vir a exercer atividade cognitiva na sequência do feito; em outras palavras, a tribunal para o qual, sempre em linha de principio, se conceba cabível, depois, outro recurso. Em tal sentido, são 'superiores', em qualquer caso, o Superior Tribunal de Justiça e o Supremo Tribunal Federal (este, aliás, nomeado em destaque no texto); na Justiça do Trabalho, haveria que acrescentar o Tribunal Superior do Trabalho, em relação aos Tribunais Regionais do Trabalho, e na Justiça Eleitoral, o Tribunal Superior Eleitoral, em relação aos Tribunais Regionais Eleitorais.”.

Dúvida que surge é: estaria o relator vinculado pelo verbete e obrigado a proferir decisão individual com base na tese jurídica sumulada? ${ }^{294}$ A resposta é negativa, já que o relator deve atuar de acordo com seu livre convencimento.

Deste modo, caso o relator entenda não ser o caso de aplicar o precedente sumulado ou entenda que as razões recursais não são contrárias ao teor da súmula, submeterá o recurso à análise do colegiado.

Mencione-se, por fim, o debate doutrinário a respeito da possibilidade de referência a súmulas de tribunal extinto, como o Tribunal Federal de Recursos, para aplicação do disposto no artigo 557 do Código de Processo Civil. A doutrina majoritária, encabeçada por Theotônio Negrão, responde afirmativamente, sob o fundamento de que as súmulas desestimulam a parte que pretende interpor recurso infundado, sem aventar novas questões que possam encorajar a revisão da tese jurídica, e de que as súmulas tem por finalidade garantir certo grau de previsibilidade dos julgamentos, o que contribui para a pacificação social.

\footnotetext{
${ }^{293}$ Comentários ao Código de Processo Civil, Lei $n^{\circ}$ 5.869, de 11 de janeiro de 1973: art. 476 a 565, vol. V. Rio de Janeiro: Editora Forense, 2008, p. 662/663.

${ }^{294}$ Lembramos que a questão do poder-dever do relator de julgar recurso individualmente, sem a participação do colegiado, já foi analisada em capítulo próprio.
} 
Discorda deste entendimento Fabiano Carvalho, por entender que uma súmula editada pelo tribunal extinto não transmite previsibilidade já que a parte não tem conhecimento de quais súmulas foram canceladas ou são eficazes e que "não se tem informação se a súmula do extinto TFR representa a posição predominante do tribunal a servir de precedente para a aplicabilidade em caso semelhante" ${ }^{, 95}$, mas ressalva que a tese jurídica compendiada em sumula de Tribunal extinto poderá produzir efeitos quando for expressamente adotada pelo tribunal que pretende a aplicar.

\section{Recurso em manifesto "confronto" com jurisprudência dominante}

O artigo 557 do Código de Processo Civil dispõe, ainda, que o relator negará seguimento a recurso em confronto com jurisprudência dominante ${ }^{296}$ do respectivo tribunal $^{297}$, do Supremo Tribunal Federal, ou de Tribunal Superior ${ }^{298}$.

\footnotetext{
${ }^{295}$ Poderes do relator nos recursos: art. 557 do CPC. São Paulo: Saraiva, 2008, p 118/119

${ }^{296}$ Doutrina e jurisprudência empregam também as expressões "jurisprudência majoritária" e "jurisprudência pacifica", com o que não concordamos. Majoritário, no nosso entender, está relacionado à superioridade numérica. Já pacífica é a jurisprudência sedimentada, inconteste o que faz com que o termo seja, portanto, mais restrito que "dominante".

${ }^{297}$ Barbosa Moreira ressalta que o correto seria "do tribunal competente para o julgamento". - FC.147

${ }^{298}$ Deveras interessante é a análise histórica feita por Barbosa Moreira. Como a jurisprudência não é o foco do nosso trabalho, tomamos a liberdade de transcrever parte do trabalho: "Tem variado bastante entre nós, ao longo dos anos, o peso da jurisprudência sobre o sentido em que deve julgar o juiz. O velho direito lusitano conheceu a figura dos "assentos": um colegiado de Desembargadores (a "Mesa grande") fixava o entendimento que se devia dar à determinada ordenação, e que se inscrevia no "livro da Relação", "para depois não vir em duvida". Daí em diante, o magistrado que deixasse de observar aquele entendimento sujeitava-se até a ser suspenso. $\mathrm{O}$ instituto subsistiu por muito tempo: consoante o art. $2^{\circ}$ do Código Civil português, "nos casos declarados em lei", poderiam os tribunais "fixar, por meio de assentos, doutrina com força obrigatória geral". Esse dispositivo, contudo, foi revogado pelo DL 329-A, de 12.12.1995".

"No Brasil imperial, o STJ tinha competência para "tomar assentos para a inteligência das leis civis, comerciais e criminais" quando na respectiva aplicação ocorressem "duvidas manifestadas por julgamentos divergentes". A Republica não recolheu esse legado; em todo caso, na Constituição de 1891 , o art. 59 , $§ 2^{\circ}$, determinava que a Justiça Federal consultasse a jurisprudência dos tribunais locais quando houvesse de aplicar leis dos Estados, e vice-versa: as justiças estaduais deveriam consultar a jurisprudência dos tribunais federais, quando lhes coubesse interpretar leis a União."

"A evolução recente do Direito brasileiro, no particular, teve marco importante na criação, em 1963, da sumula da jurisprudência predominante do STF. Inspirava-se ela no proposito de atenuar o crônico problema da sobrecarga de trabalho da Corte Suprema - e, indiretamente, do Judiciário como um todo. Normas regimentais atribuíram efeitos relevantes à inclusão de uma tese jurídica na Sumula; ela chegou a influir na questão do cabimento do recurso extraordinário, na época em que o STF se viu constitucionalmente autorizado a regular a matéria: assim, as restrições a que se submetia o cabimento não prevaleciam nos casos de divergência entre a decisão impugnada e a Sumula."

"O anteprojeto do CPC, de autoria de ALFREDO BUZAID, intentou ressuscitar o mecanismo dos antigos assentos. Resolvido o incidente da uniformização da jurisprudência, a decisão sobre a tese jurídica tomada pela maioria absoluta dos membros efetivos do tribunal - do STF ou do Tribunal de Justiça, conforme se tratasse,
} 
Plácido e Silva conceitua jurisprudência como a "sábia interpretação e aplicação das leis a todos os casos concretos que se submetam a julgamento da justiça. Ou seja, o hábito de interpretar e aplicar as leis aos fatos concretos, para que, assim, se decidam as causas. Desse modo, a jurisprudência não se forma isoladamente, isto é, pelas decisões isoladas. É necessário que se firme por sucessivas e uniformes decisões, constituindo-se em fonte criadora do Direito e produzindo um verdadeiro jus novum. É necessário que, pelo hábito, a interpretação e explicação das leis a venham formar. (...) Mas, a verdade é que a jurisprudência firmada, em sucessivas decisões, vale como verdadeira lei. Jurisprudência. Extensivamente assim se diz para designar o conjunto de decisões acerca de um mesmo assunto ou a coleção de decisões de um tribunal"299.

E Miguel Reale define jurisprudência como "a forma de revelação do direito que se processa através do exercício da jurisdição, em virtude de uma sucessão harmônica de decisões dos tribunais". Fabiano Carvalho, por sua vez, leciona que "é a produção decisória, em série, dos tribunais, por meio dos seus órgãos colegiados, no exercício da sua jurisdição, sobre determinada matéria jurídica de sua competência. A finalidade da jurisprudência é atribuir à norma jurídica a unidade de interpretação" 300 .

A redação do artigo 557 do Código alude a jurisprudência dominante, termo que causa perplexidade e enseja debate acirrado na doutrina. "A apuração do que é jurisprudência dominante pode oferecer óbices intransponíveis em face da natural alteração da orientação

respectivamente, de norma jurídica federal ou estadual -, seria obrigatória enquanto não modificada por outro acordão proferido na mesma forma. Caberia ao presidente do tribunal, em obediência ao decidido, baixar assento, que teria força de lei 45 dias apos a publicação oficial (arts. 518, 519, 520, paragrafo único). Tal sistemática foi criticada em sede doutrinaria, antes de mais nada por inconstitucional. O projeto abandonou a solução dos assentos com força de lei e deu à matéria nova feição, inspirada na Sumula do STF e conservada, com alterações de pormenor, pelo Congresso Nacional. Todavia, o expediente da uniformização de jurisprudência, regulado nos arts. 476 e ss. Do Código, jamais alcançou a desejada eficiência; e outro tanto se pode afirmar, já agora à luz da experiência de alguns anos, do mecanismo introduzido no art. $555 \S 1^{\circ}$, pela Lei $\mathrm{n}^{\circ} 10.352$, de 27.12.2001". MOREIRA, José Carlos Barbosa. Súmula, Jurisprudência, Precedente: uma escalada e seus riscos. Revista Síntese de Direito Civil e Processual Civil. Ano VI, n 35, p. 5/7 mai./jun. 2005

${ }^{299}$ Apud FILHO, Nagib Slabi. Notas sobre o art. 557 do CPC (competência do relator de prover e de negar seguimento a recurso). Revista Forense, Rio de Janeiro, v. 361, ano 98, p.106.

${ }^{300}$ Poderes do relator nos recursos: art. 557 do CPC. São Paulo: Saraiva, 2008, p.122. 
seguida pelas Cortes, embora muito facilitem as ementas de acordão, como algumas das Seções do Superior Tribunal de Justiça, declarando tal condição"301.

Como bem acentuado por Barbosa Moreira, a expressão não possui contornos precisos tendo em vista que o predomínio de uma tese pode e costuma variar com o tempo e, consequentemente, "seria erro grave arvorar sempre em critério definitivo e imutável, digno de sobrepor-se a tudo mais, uma tendência contingente, embora reiterada, a dar a tal ou qual norma determinada interpretação" 302 .

Críticas severas à redação do dispositivo foram feitas por Nagib Slabi Filho, para quem “A questão, aqui qualificada de seríssima - porque de certo modo rompe com a tradição dos julgamentos colegiados nos Tribunais, ainda que se trate de decisão recorrível -, mereceu tal qualificação em razão da pouca probabilidade de que se tenha conhecimento, com base em levantamentos estatísticos confiáveis, daquela que seja a jurisprudência dominante num determinado Tribunal. (...) esse expressão - "jurisprudência dominante" - é absolutamente fluida, indeterminada, sendo difícil para a parte recorrente quantificar a jurisprudência a ponto de saber, com desejável grau de probabilidade de acerto, se se trata ou não de "dominante"303.

Sérgio Cruz Arenhart sustenta que a ideia "de jurisprudência dominante, capaz de ensejar o julgamento monocrático do recurso, há de ser vista sob o mesmo prisma da súmula, como algo que representa a visão majoritária de uma corte, assim como esta. É nesse sentido que parece adequado entender que a jurisprudência dominante apta a autorizar a aplicação dos arts. 544, $\S 3^{\circ}$, e 557 do $\mathrm{CPC}$, seja a decisão, objeto de incidente de uniformização de jurisprudência, onde não se logrou atingir o quórum especial, exigido para elaboração de uma súmula"304.

\footnotetext{
${ }^{301}$ FILHO, Nagib Slabi. Notas sobre o art. 557 do CPC (competência do relator de prover e de negar seguimento a recurso). Revista Forense, Rio de Janeiro, v. 361, ano 98, p. 104.

${ }_{302}^{30}$ Reformas processuais e poderes do juiz. In: Temas de Direito processual, $8^{\mathrm{a}}$ série, p. 66.

${ }^{303}$ WAMBIER, Luiz Rodrigues. Uma proposta em torno do conceito de jurisprudência dominante. Revista de Processo. N. 100, ano 25, p. 81-86, out./dez 2000. Editora Revista dos Tribunais, p. 82.

${ }^{304}$ A nova postura do relator no julgamento dos recursos. Revista de Processo, São Paulo: Revista dos Tribunais, vol. 103, p.37-58, jul./set./2001, p. 49.
} 
Para Nagib Slabi Filho ${ }^{305}$, a jurisprudência dominante é representada por sucessivas decisões sobre o mesmo tema em orientação convergente. No entanto, admite o autor que até mesmo uma única decisão possa representar a jurisprudência dominante, "se ela foi tomada pela maioria absoluta de órgão que disponha de competência exclusiva sobre o tema, como, por exemplo, o Plenário do Supremo Tribunal Federal em matéria constitucional, ao afirmar a compatibilidade ou a incompatibilidade da norma em face da Lei Maior”.

Carreira Alvim faz importante distinção entre súmula e jurisprudência dominante, afirmando que "a súmula é mais do que a jurisprudência predominante no tribunal, embora tenha por base essa jurisprudência. Só é objeto de súmula o julgamento tomado pelo voto da maioria dos membros que integram o tribunal, constituindo precedente na uniformização da jurisprudência (art. 479 do CPC). Além disso, aprovada e regularmente publicada a súmula, obriga os órgãos fracionários do tribunal (câmaras, turmas, sessões), por expressa disposição dos regimentos internos dos tribunais." ${ }^{\text {,306. }}$

Mas, como definir o que é jurisprudência "dominante" que autorize o relator a julgar unipessoalmente o recurso? Priscila Kei Sato $^{307}$ entende que deveriam ser utilizados os mesmos critérios de que se serve o Supremo Tribunal Federal para considerar predominante a sua jurisprudência, quais sejam, a existência "de mais de um acordão que reflita aquele entendimento, ou unicidade de decisão" e aponta, ainda, que poderia ser adotada como “jurisprudência dominante" a decisão do Tribunal Pleno, ainda que não tenha havido unanimidade de votos no julgamento da matéria.

Luis Rodrigues Wambier discorda dos parâmetros por ela traçados e defende a utilização do critério de porcentagem de decisões delimitadas por determinado espaço de tempo: "o entendimento da Corte Especial do STJ, a respeito da interpretação do direito federal, poderia considerar-se dominante se houvesse reiteração das decisões majoritárias

\footnotetext{
${ }^{305}$ FILHO, Nagib Slabi. Notas sobre o art. 557 do CPC (competência do relator de prover e de negar seguimento a recurso). Revista Forense, Rio de Janeiro, v. 361, ano 98, p..106.

${ }^{306}$ Recursos, extraordinário e especial, na reforma processual. In: Aspectos polêmicos e atuais dos recursos, p. 289.

307 Kei Sato - "Jurisprudência (pre)dominante". Aspectos polêmicos e atuais dos recursos. Coord. Eduardo Pellegrini de Arruda Alvim, Nelson Nery Jr e Teresa Arruda Alvim Wambier, São Paulo: RT, 2000, p. 583
} 
daquela Corte, no mesmo sentido, na proporção de 70 a 30\%, durante o período de 5 anos (ou 3, ou 2 anos, por exemplo, contados retroativamente), ${ }^{\text {,308 }}$. Wanessa Françolin ${ }^{309}$, por sua vez, também indica um critério numérico e manifesta o entendimento que por dominante deve-se entender a maioria simples de julgados $(50 \%+1)$.

Cândido Rangel Dinamarco discorda da utilização de critérios numéricos, afirmando que "os relatores e os tribunais devem ter a consciência de que inexiste um critério quantitativo que seja suficiente para sua especificação". 310 Afirma o autor, ainda, que “jurisprudência dominante será não somente aquela decidida em incidentes de uniformização de jurisprudência, mas também a que estiver presente em número significativo de julgados, a critério do relator" ${ }^{\prime 311}$.

Fabiano Carvalho defende que "é indispensável que os tribunais deem 'publicidade' a respeito de sua orientação sobre determinado tema jurídico. Essa veiculação do entendimento dominante transmite confiança ao relator para julgar unipessoalmente recurso, bem como previsibilidade e segurança aos jurisdicionados" ${ }^{„ 312}$. O entendimento do autor é complementado pelo de Athos Gusmão Carneiro ${ }^{313}$, para quem a tarefa de identificar qual a jurisprudência que esteja a prevalecer em determinado tribunal é relativamente fácil nos tempos atuais, ainda mais se considerada a disponibilidade possibilitada pelos meios informáticos.

\footnotetext{
${ }^{308}$ Discorre o autor: "É preciso um período referencial para que se possa falar em jurisprudência dominante. Assim, o entendimento da Corte Especial do Superior Tribunal de Justiça, a respeito da interpretação do direito federal, poderia considerar-se dominante se houvesse a reiteração de decisões majoritárias daquela Corte, no mesmo sentido, na proporção de $70 \%$ para 30\%, durante o período de cinco anos (ou três anos, ou dois anos, por exemplo, contados retroativamente). A adoção de critério de precedentes não se fara com seriedade, em nosso sistema, se não houver uma base estatística confiável, que permita à sociedade aferir objetivamente, longe dos humores deste ou daquele julgador, qual efetivamente seja o pensamento dominante no Superior Tribunal de Justiça (...) a respeito daquela matéria, num determinado período (período referencial). WAMBIER, Luiz Rodrigues. Uma proposta em torno do conceito de jurisprudência dominante. Revista de Processo. N. 100, ano 25 , p. $85 / 86$.

${ }^{309}$ A ampliação dos poderes do relator nos recursos cíveis. Rio de Janeiro: Editora Forense, 2006, p. 94.

${ }^{310}$ A Reforma da Reforma. São Paulo: Malheiros, 2002, p. 187.

${ }^{311}$ VIVEIROS, Estefânia. Agravo Interno no Superior Tribunal de Justiça e ampliação dos podres do relator. Universitas/jus. $\mathrm{n}^{\circ} 7, \mathrm{p} .71$.

${ }^{312}$ Poderes do relator nos recursos: art. 557 do CPC. São Paulo: Saraiva, 2008, p.137/138.

${ }^{313}$ Recurso especial, agravos e agravo interno, p. 243/244.
} 
Novamente trazemos à baila a lição de Sergio Arenhart ${ }^{314}$ e de Barbosa Moreira ${ }^{315}$, que fazem uma importante ressalva. Os autores lembram que em uma única sessão de julgamento pode ser proferido número expressivo de recursos versando sobre a mesma matéria. Afirmam que em casos tais, não se poderia considerar formada jurisprudência dominante, seja do tribunal, seja daquela específica turma tomando por base apenas uma única sessão de julgamento, em certo dia específico e diante de dada composição do colegiado.

Pode surgir, ainda, alguma perplexidade no momento de decidir qual a orientação a ser adotada caso a jurisprudência dominante no tribunal seja oposta à de súmula ou da jurisprudência dominante no Superior Tribunal de Justiça ou no Supremo Tribunal Federal.

Para o Superior Tribunal de Justiça, a expressão "jurisprudência dominante do respectivo tribunal" somente poderá servir de base para negar seguimento s recurso quando o entendimento adotado nesse tribunal estiver de acordo com a jurisprudência do Superior Tribunal de Justiça e do Supremo Tribunal Federal ${ }^{316}$.

O mesmo entendimento é esposado por Wambier ${ }^{317}$, para quem "Ao prever que possa o relator negar seguimento a recurso que confronte com a jurisprudência dominante do respectivo tribunal, a lei somente pode ter querido referir-se à hipótese de existir jurisprudência local que não colida com aquilo que também no Superior Tribunal de Justiça se tiver entendido como tal".

Outro ponto que merece destaque diz respeito à contemporaneidade da jurisprudência dominante. Bem se sabe que os Tribunais podem - e, ouse-se dizer, devem - rever uma posição anteriormente pacificada, de modo a adequar a interpretação da norma a uma nova conjetura. Deste modo, a jurisprudência dominante deve ser atual, "entendida como aquela que ocorre no momento presente, extraída das decisões recentes do tribunal, com sua

\footnotetext{
${ }^{314}$ Inovações da Lei 9.756 em matéria de recursos civis. In WAMBIER, Teresa Arruda Alvim; NERY JUNIOR, Nelson (coord.). Aspectos polêmicos e atuais dos recursos cíveis de acordo com a Lei 9.756/98. São Paulo: Revista dos Tribunais, 1999, p. 325.

${ }^{315}$ BARBOSA MOREIRA, José Carlos. “Algumas inovações da Lei 9.756 em matéria de recurso cíveis”, p. 325

${ }^{316}$ REsp 193.189

${ }^{317}$ WAMBIER, Luiz Rodrigues. Uma proposta em torno do conceito de jurisprudência dominante. Revista de Processo. N. 100, ano 25, p. 84.
} 
composição contemporânea" ${ }^{318}$. Em outras palavras, a jurisprudência obsoleta, ainda que tenha sido dominante em determinado período, não pode ser considerada como fundamento que autorize o julgamento monocrático do recurso.

Mencione-se ser possível a utilização de jurisprudência dominante de tribunal já extinto desde que o entendimento tenha sido mantido e reiterado pelo tribunal sucessor.

Mais uma questão exsurge da análise do artigo 557 do Código de Processo Civil e diz respeito à possibilidade de adoção de jurisprudência dominante de órgão fracionário. Como se sabe, o tribunal é composto de órgãos cuja jurisprudência, a depender de sua composição, pode não representar necessariamente a jurisprudência dominante do tribunal já que, não raro, os órgãos do tribunal divergem sobre o mesmo assunto jurídico.

Segundo Cândido Rangel Dinamarco 319 “não é necessário que a jurisprudência seja dominante do plenário de um dos tribunais indicados no art. 557 - podendo tratar-se de uma linha adotada majoritariamente (rectius: dominantemente) em seus órgãos fracionários sem que a proposito haja qualquer manifestação daquele". Fabiano Carvalho ${ }^{320}$ adota entendimento contrário e defende que correndo a dissensão equilibrada entre câmaras ou turmas do tribunal, não há que se falar em jurisprudência dominante.

Suscita debate também a questão de a quem cabe a demonstração de que a jurisprudência usada como parâmetro para fins de aplicação do artigo 557 do Código de Processo Civil é dominante, se ao relator, como fundamento de sua decisão, ou à parte, como razão de agravo interno.

A jurisprudência dominante deve ser ao menos indicada pelas partes, embora caiba ao relator o juízo sobre a incidência dos elementos normativos no caso em julgamento.

\footnotetext{
${ }^{318}$ Poderes do relator nos recursos: art. 557 do CPC. São Paulo: Saraiva, 2008, p. 133.

${ }^{319}$ A Reforma da Reforma. São Paulo: Malheiros, 2002, p.188/189.

${ }^{320}$ Poderes do relator nos recursos: art. 557 do CPC. São Paulo: Saraiva, 2008, p..135.
} 
Como já visto em capítulo próprio, a decisão monocrática deve ser devidamente fundamentada. Assim, ao aplicar o artigo 557 do Código de Processo Civil, o relator deve não apenas indicar a jurisprudência usada como razão de decidir ${ }^{321} 322$, mas também os motivos pelos quais entende que a tese recursal contraria a jurisprudência dominante do tribunal ou dos tribunais superiores.

Importante destacar que o precedente jurisprudencial dominante há de ser o fundamento da decisão monocrática, sendo que a jurisprudência invocada não tem por função reforçar as justificativas da decisão, mas de fundamentar a aplicação do disposto no artigo 557 do Código de Processo Civil.

O relator, no entanto, deve ter cautela ao utilizar-se de "jurisprudência dominante" para julgar o recurso unipessoalmente. Como a expressão não possui contornos precisos, já que o predomínio desta ou daquela tese pode e costuma variar com o tempo, se dúvida houver a respeito da prevalência de determinado entendimento jurisprudencial, será preferível abrir ao colegiado a oportunidade de analisar o recurso ${ }^{323}$.

De igual modo, a parte, caso recorra da decisão monocrática baseada em “jurisprudência dominante”, não poderá limitar-se a pedir a apreciação do recurso pelo órgão colegiado $^{324}$; deverá demonstrar a inexistência de "jurisprudência dominante" que autorize a aplicação do artigo 557 do Código de Processo Civil, comprovando que a jurisprudência do

\footnotetext{
${ }^{321}$ Julgados há que consideram suficiente a citação de um julgado que retrate com fidelidade o entendimento dominante do tribunal.

${ }^{322}$ Fabiano Carvalho sugere que os relatores evitem citar acórdãos em que tenham figurado como relatores ou condutores do voto, já que a decisão monocrática deve ter por base a posição do tribunal e não a sua. - FC.143

${ }^{323}$ MOREIRA, José Carlos Barbosa. Reformas Processuais e Poderes do Juiz. Revista de Direito do Tribunal de Justiça do Estado do Rio de Janeiro. n. 56, p. 24. No mesmo sentido: "Tem-se, ademais, criticado a expressão "jurisprudência dominante" por ela ser de cunho eminentemente subjetivo, conforme ja noticiado, porque a lei silenciou acerca dos parâmetros necessários à configuração do que seria "dominante". (...) Precisa então o relator, nessas hipóteses, sentir-se seguro de que o resultado do julgamento monocrático seria o mesmo do colegiado, na hipótese de o recurso ser levado à apreciação desse órgão". VIVEIROS, Estefânia. Agravo Interno no Superior Tribunal de Justiça e ampliação dos podres do relator. Universitas/jus. ${ }^{\circ}$ 7, p. 71.

${ }^{324}$ Lembremos que a parte tem o ônus de impugnação especifica aos fundamentos da decisão recorrida, de modo que a mera reiteração das razoes expendidas no recurso apreciado monocraticamente impede o conhecimento do agravo interno.
} 
tribunal ou não é aquela afirmada pelo relator ou contraria orientação do Supremo Tribunal Federal e/ou de Tribunais Superiores ${ }^{325}$.

\section{Decisão recorrida em manifesto "confronto" com súmula ou jurisprudência dominante do Supremo Tribunal Federal e/ou de Tribunais Superiores}

O artigo 557, $\S 1^{\circ}$-A, do Código de Processo Civil dispõe que o relator poderá dar provimento ao recurso se a decisão recorrida estiver em manifesto "confronto" com súmula ou com jurisprudência dominante do Supremo Tribunal Federal ou de tribunal superior.

Aqui, ao contrário da hipótese do caput, trata-se de recurso procedente, de modo que os fundamentos da decisão recorrida é que são tidos por contrários à jurisprudência dominante.

Além disso, também diferentemente da redação do caput, que autoriza o desprovimento do recurso em contraste com a jurisprudência do "respectivo tribunal", o $\S 1^{\text {o- }}$ A não contempla a hipótese de o relator adotar como fundamento a jurisprudência do tribunal local. Segundo Sérgio Bermudes, não se sabe se referida exclusão foi feita "por descuido ou por ter reputado mais importante a situação de provimento do recurso do que a de desprovimento, previsto no caput." ${ }^{, 326}$.

Ao analisar as diferenças de redação, Fabiano Carvalho ${ }^{327}$ manifesta o entendimento de que a exegese é justificável por duas razões: “(i) inversamente do que ocorre quando se preserva a decisão impugnada, o grau de erro judiciário torna-se mais vulnerável na medida em que há reforma da decisão, pois será exercido um novo juízo de valor, muito provavelmente em sentido contrário ao próprio fundamento da decisão recorrida; (ii) os tribunais de superposição, como órgãos máximos da hierarquia judiciaria, têm função de estabelecer a unidade de interpretação do direito, o que não é tarefa do tribunal de segundo grau de jurisdição".

\footnotetext{
${ }^{325}$ CIANCI, Mirna. A lei 9.756/1998 (CPC, artigos 544, par. $3^{\circ}$ e 557, pars. $1^{\circ}$ a $3^{\circ}$ ) e a ampliação dos poderes do relator, dez anos depois. Revista Brasileira de Direito Processual RDBPro. ano 16, n. 61, p.114.

${ }^{326}$ Nota à atualização legislativa e dos comentários ao Código de Processo Civil. T. VII de Pontes de Miranda, p. 228.

${ }^{327}$ Poderes do relator nos recursos: art. 557 do CPC. São Paulo: Saraiva, 2008, p. 152/153.
} 
Polêmica que surgiu em sede doutrinária e jurisprudencial diz respeito à necessidade de prévia intimação da parte contrária para apresentar resposta a agravo de instrumento nos casos em que o relator entenda ser o caso de aplicação do artigo 557, § $1^{\circ}$-A, do Código de Processo Civil.

Como se sabe, o agravo de instrumento é interposto diretamente no juízo ad quem e, consequentemente, chega às mãos do relator sem o estabelecimento do contraditório. Assim, a única versão que chega ao relator é a do agravante e as peças que formam o instrumento são apenas aquelas apresentadas pelo agravante ${ }^{328}$.

Nos casos em que o julgamento monocrático é desfavorável ao agravante, não há dúvidas quanto à possibilidade de julgamento monocrático de agravo de instrumento sem a prévia ciência ao agravado para responder o recurso. Isso porque a inadmissão ou desprovimento do recurso não atingira a esfera jurídica do agravado, sendo, portanto, prescindível a sua participação ${ }^{329}$.

Ao revés, a decisão que dá provimento ao recurso poderá afetar os interesses do agravado e é por esta razão que se iniciou intenso debate a respeito da possibilidade de representar ofensa ao contraditório o julgamento monocrático realizado sem que ao recorrido tenha sido concedida a oportunidade de se manifestar.

Fredie Didier Jr. e Leonardo José Carneiro da Cunha entendem que "No caso de lhe dar provimento (ao agravo), parece necessário instaurar-se, previamente, o contraditório, a fim de que o agravado possa ter a oportunidade de demonstrar que o caso não se enquadra na hipótese de manifesto contraste com súmula de tribunal superior ou de jurisprudência do Plenário do STF",330.

\footnotetext{
${ }^{328}$ OLIVEIRA, Pedro Miranda. Poderes do Relator no Agravo de Instrumento: impossibilidade de provimento singular sem a oitiva da parte agravada. Revista Dialética de Direito Processual. V. 81, p. 97.

${ }^{329}$ PINTO, Christian Barros. A eficácia da decisão envolvendo a repercussão geral e os novos poderes dos relatores e dos tribunais locais. Revista Dialética de Direito Processual V.97, p. 17.

${ }^{330}$ Apud PINTO, Christian Barros. A eficácia da decisão envolvendo a repercussão geral e os novos poderes dos relatores e dos tribunais locais. Revista Dialética de Direito Processual V.97.
} 
Luiz Guilherme Marinoni e Sérgio Cruz Arenhart aduzem que "quando o relator 'recebe' o agravo, ainda não houve o exercício do contraditório, e não é possível dar provimento a recurso sem antes conferir ao recorrido oportunidade para apresentar suas razões" ${ }^{331}$.

Segundo Araken de Assis "apesar da ausência de nulidade, a visão liberal recomenda, em homenagem contrita ao contraditório, a intimação pessoal do próprio agravado, constando seu endereço nos traslados, justamente para constituir advogado e, mostrando-se oportuno, responder ao agravo" ${ }^{, 332}$.

No mesmo sentido é a lição de Luiz Rodrigues Wambier e Teresa Arruda Alvim Wambier, para quem, "o relator não pode, sob qualquer pretexto, dar provimento ao recurso sem estabelecer o contraditório, por mais manifestas que sejam as situações ocorrentes (das listadas no $\left.\S 1^{\circ}-\mathrm{A}\right)^{, 333}$.

A controvérsia foi analisada pelo Superior Tribunal de Justiça que, no julgamento do Recurso Especial Repetitivo de n. 1.148.296/SP, pacificou o entendimento de ser obrigatória a intimação prévia do agravado para responder o recurso nos casos de provimento monocrático do agravo de instrumento ${ }^{334}$.

\footnotetext{
${ }^{331}$ Apud PINTO, Christian Barros. A eficácia da decisão envolvendo a repercussão geral e os novos poderes dos relatores e dos tribunais locais. Revista Dialética de Direito Processual V.97.

${ }^{332}$ Manual dos Recursos Cíveis. São Paulo: RT, 2007, p. 520

333 Apud OLIVEIRA, Pedro Miranda. Poderes do Relator no Agravo de Instrumento: impossibilidade de provimento singular sem a oitiva da parte agravada. Revista Dialética de Direito Processual. V. 81, p. 98, dez.l 2009.

334 PROCESSUAL CIVIL. TRIBUTÁRIO. RECURSO ESPECIAL REPRESENTATIVO DE CONTROVÉRSIA. ART. 543-C, DO CPC. AGRAVO DE INSTRUMENTO. ART. 527, V, DO CPC. AUSÊNCIA DE INTIMAÇÃO DO AGRAVADO PARA RESPOSTA. OBRIGATORIEDADE. NULIDADE. O PRINCÍPIO DO PREJUÍZZO IMPEDE A APLICAÇÃO DA REGRA MATER DA INSTRUMENTALIDADE. VIOLAÇÃO DO ART. 535 DO CPC. NÃO-OCORRÊNCIA.

1. A intimação da parte agravada para resposta é procedimento natural de preservação do princípio do contraditório, nos termos do art. 527, V, do CPC, in verbis:

"Art. 527. Recebido o agravo de instrumento no tribunal, e distribuído "incontinenti", o Relator:

(...)

$V$ - mandará intimar o agravado, na mesma oportunidade, por ofício dirigido ao seu advogado, sob registro e com aviso de recebimento, para que responda no prazo de dez (10) dias(art. 525, $\S 2^{\circ}$ ), facultando-lhe juntar a documentação que entender conveniente, sendo que, nas comarcas sede de tribunal e naquelas em que o expediente forense for divulgado no diário oficial, a intimação far-se-á mediante publicação no órgão oficial."
} 
Há, ainda, a hipótese de julgamento de apelação contra sentença que indefere a petição inicial, sendo que a decisão monocrática poderia ser favorável ao autor da ação não obstante a ausência do réu no procedimento. $\mathrm{O}$ autor defende não existir ofensa ao contraditório e suscita o entendimento de José Carlos Barbosa Moreira no sentido de que a reforma da sentença "não gera preclusão, para o réu, no tocante às questões de cujo exame dependia a admissão ou a rejeição da inicial", de modo que o réu fica "inteiramente livre de suscitá-las em defesa, tal como ficaria se houvesse o juiz deferido ab initio a petição" ${ }^{\text {335. }}$.

2. A dispensa do referido ato processual ocorre tão-somente quando o relator nega seguimento ao agravo (art. 527, I), uma vez que essa decisão beneficia o agravado, razão pela qual conclui-se que a intimação para a apresentação de contra-razões é condição de validade da decisão que causa prejuízo ao recorrente. (Precedentes: REsp 1187639/MS, Rel. Ministra ELIANA CALMON, SEGUNDA TURMA, julgado em 2005/2010, DJe 3105/2010; AgRg nos EDcl nos EDcl no REsp 1101336RS, Rel. Ministro HERMAN BENJAMIN, SEGUNDA TURMA, julgado em 0202/2010, DJe 0203/2010; REsp 1158154RS, Rel. Ministro CASTRO MEIRA, SEGUNDA TURMA, julgado em 19/11/2009, DJe 27/11/2009; EREsp 882.119/RS, Rel. Ministro HUMBERTO MARTINS, PRIMEIRA SEÇÃO, julgado em 13/05/2009, DJe 25/05/2009; EREsp 1038844PR, Rel. Ministro TEORI ALBINO ZAVASCKI, PRIMEIRA SEÇÃO, julgado em 08/10/2008, DJe 20/10/2008)

3. Doutrina abalizada perfilha o mesmo entendimento, verbis:

"Concluso o instrumento ao relator, nas 48 horas seguintes à distribuição (art. 549, caput), cabe-lhe, de ofício, se configurada qualquer das hipóteses do art. 557 caput, indeferir liminarmente o agravo (inciso I). Não sendo esse o caso, compete-lhe tomar as providências arroladas nos outros incisos do art. 527.

(...)A subsequente providência - cuja omissão acarreta nulidade - consiste na intimação do agravado." (José Carlos Barbosa Moreira, in Comentários ao Código de Processo Civil, Vol. V, 15a ed., Ed. Forense, p. 514)

4. In casu, o acórdão recorrido deu provimento ao agravo de instrumento do Município de São Paulo, causando evidente prejuízo aos agravados, ora recorrentes, por isso que merece ser reformado.

5. O art. 535 do CPC resta incólume se o Tribunal de origem, embora sucintamente, pronuncia-se de forma clara e suficiente sobre a questão posta nos autos. Ademais, o magistrado não está obrigado a rebater, um a um, os argumentos trazidos pela parte, desde que os fundamentos utilizados tenham sido suficientes para embasar a decisão.

6. Recurso especial provido, determinando-se o retorno dos autos à instância de origem, para que proceda à intimação do recorrente para apresentação de contra-razões ao agravo de instrumento. Prejudicadas as demais questões suscitadas. Acórdão submetido ao regime do art. 543-C do CPC e da Resolução STJ 08/2008.

${ }^{335}$ PINTO, Christian Barros. A eficácia da decisão envolvendo a repercussão geral e os novos poderes dos relatores e dos tribunais locais. Revista Dialética de Direito Processual V.97, p..21 


\section{CAPITULO 6 - O JULGAMENTO MONOCRÁTICO DO RECURSO REALIZADO COM BASE NO ARTIGO 557 DO CÓDIGO DE PROCESSO CIVIL}

\section{Competência do relator}

Regra geral, a competência para o julgamento dos recursos é atribuída aos tribunais. Os tribunais são, internamente, divididos em órgãos colegiados (v.g., turma, câmara) ${ }^{336}$ e órgãos individualizados (v.g., presidente, vice-presidente, corregedor, relator, revisor) ${ }^{337}$.

A divisão dos órgãos colegiados é definida pelo Código de Processo Civil e pelos regimentos internos dos tribunais. Por exemplo, no julgamento colegiado de apelação ou de agravo, a decisão será tomada pelo voto de três juízes (artigo 555 do Código de Processo Civil), ou, ocorrendo relevante questão de direito, que faça conveniente prevenir ou compor divergência entre câmaras ou turmas do tribunal, poderá o relator propor seja o recurso julgado pelo órgão colegiado que o regimento indicar (art. 555, $§ 1^{\circ}$, do Código de Processo Civil). Mencionem-se ainda os embargos infringentes e os embargos divergentes, cujo julgamento colegiado ocorrerá conforme dispuser o regimento interno do tribunal (artigos 533 e 546, § único, do Código de Processo Civil).

Já aos órgãos individualizados dos tribunais cabe o exame prévio de admissibilidade dos recursos extraordinário e especial (a tarefa compete, no caso, ao presidente ou vicepresidente do tribunal recorrido - artigos 541 e 542, §1 ambos do Código de Processo Civil), o exercício de determinados atos de procedimento recursal como a requisição de informações ao juiz da causa (artigo 527, IV, do Código de Processo Civil) e o julgamento dos recursos na forma do artigo 557 do Código de Processo Civil, objeto deste estudo.

\footnotetext{
${ }^{336}$ Conforme delineiam Cintra, Dinamarco e Grinover "Cada um dos tribunais é dividido em câmaras, que se reúnem formando grupos de câmaras. A reunião de todas as câmaras de um tribunal leva ordinariamente o nome Tribunal Pleno (no Tribunal de Justiça, por força da Constituição e da Lei Orgânica da Magistratura Nacional, ha o órgão especial, composto dos vinte e cinco desembargadores mais antigos , que desempenha funções jurisdicionais e administrativas antes atribuídas ao Plenário (...). A lei estadual estabelece a competência de cada um desses colegiados que compõem o Tribunal, observada a Lei orgânica da Magistratura Nacional". (Op. cit., p. 187)

${ }^{337}$ CARVALHO, Fabiano. Op. cit., p. 49.
} 
A atual redação do artigo 557 outorgou ao relator competência para decidir sobre os recursos encaminhados para exame e decisão, competência esta antes atribuída somente aos órgãos colegiados do Poder Judiciário ${ }^{338}$. Surgiu então o questionamento: os julgamentos monocráticos poderiam ser enquadrados como uma "delegação" da função jurisdicional, do colegiado para a pessoa do relator?

A doutrina majoritária responde afirmativamente. Nelson Nery Junior afirma que, como a decisão está sujeita ao controle do órgão colegiado competente para julgar o recurso, o relator atua de forma "preliminar", com função delegada do órgão colegiado a que pertence",339.

Sérgio Cruz Arenhart entende que o procedimento do artigo 557 do Código de Processo Civil importa em delegação da função da corte ao relator, que age em nome do colegiado e sujeita-se, quando extrapola os limites da concessão, à reapreciação de seus atos pelo órgão originariamente competente, verbis: “Ora, indubitavelmente, quando a lei se refere ao 'órgão competente para julgamento do recurso', aponta ela para a conclusão de que existe um órgão competente para o julgamento daquele primeiro recurso (o agravo de instrumento), que não é o relator - ou, então, ficaria sem nenhum sentido a previsão legal. Tem-se, então, que a própria lei considera que há um órgão originariamente competente para o julgamento do recurso (o colegiado), e que esta atribuição será delegada, em razão de certas particularidades da questão submetida à apreciação - particularidades estas relacionadas à evidência do tema debatido e, portanto, à certeza quanto à conclusão da corte - a apenas um dos membros daquele órgão plural" ${ }^{340}$. Acrescenta o autor que: "O mesmo se há de dizer no atinente ao preceito contido no art. 557. Também ali se observa a alusão a que o relator "negará seguimento" ao recurso, que somente terá seu curso natural, para o "órgão competente para o julgamento do recurso" (art. 557, $\S 1^{\circ}$ ), em havendo nova provocação da parte interessada,

\footnotetext{
${ }^{338}$ CUNHA, Eurípedes Brito. Despacho/decisão do relator: natureza jurídica; possibilidade de desconstituição por via de ação rescisória. Revista Síntese de Direito Civil e Processual Civil, Porto Alegre, v.3, n.18, p.32-7, jul./ago. 2002, p. 33.

${ }^{339}$ NERY JUNIOR, Nelson. Princípios fundamentais: teoria geral dos recursos. 5. Ed., São Paulo: RT, 2000, p. 238.

${ }^{340}$ ARENHART, Sérgio Cruz. Op. cit., p. 42
} 
mediante aquilo a que a lei se refere como "agravo". Neste caso, conforme ainda estabelece claramente a lei, em sendo provido o tal "agravo", "o recurso terá seguimento" (art. 557, $\S 1^{\circ}$, in fine)".

Barbosa Moreira ${ }^{341}$, por sua vez, aduz que o relator "atua como uma espécie de portavoz do colegiado" está adstrito às hipóteses previstas em lei - binômio súmula e precedentes jurisprudenciais dominantes - para as quais já houve, anteriormente, a chancela do colegiado. Sérgio Cruz Arenhart, ao comentar as palavras do mestre, afirma que o como o relator não age em nome próprio, mas sim como representante do colegiado, deve decidir monocraticamente apenas em casos em que a questão seja de evidente solução e sua manifestação deve corresponder à deliberação a que chegaria o colegiado sob o thema decidendum caso o recurso fosse levado à sua apreciação ${ }^{342} 343$.

Também posiciona-se no sentido de que o relator age por delegação do colegiado de que faz parte, Nagib Slaibi Filho. Para o autor, como o Supremo Tribunal Federal já manifestou o entendimento de que a constitucionalidade do julgamento monocrático de recursos depende da possibilidade de a decisão do relator possa ser submetida ao controle do colegiado, “o poder monocrático do relator é derivado do poder do colegiado, a quem o relator

\footnotetext{
${ }^{341}$ BARBOSA MOREIRA, José Carlos. Comentários... Op. cit..

${ }^{342}$ ARENHART, Sérgio cruz. Op. cit., p. 43.

${ }^{343}$ Comungam do entendimento de que o relator atua como delegado do órgão a que pertence SLAIBI FILHO, Nagib. Op. cit., p.98; CUNHA, Eurípedes Brito. Op. cit., p.33, CIANCI, Mirna, Op. cit., p.111 e PEREIRA, Milton Luiz. Embargos de divergência contra decisão lavrada por relator. Revista Forense, Rio de Janeiro, v.99, n.366, mar./abr. 2003, p. 377. O tema também já foi apreciado pelo Superior Tribunal de Justiça, conforme se observa dos seguintes arestos:

"Registro, em adendo, que o Relator, quando exerce a competência outorgada pelo artigo 557, atua como órgão do tribunal. Tanto quanto os acórdãos dos colegiados, a decisão do relator, nesta circunstancia, é ato do Tribunal.” (REsp n ${ }^{\circ} 227.904-R S, 1^{a}$ Turma, Rel. Min. Garcia Vieira, j. 16.11.1999)

"o art. 557 do CPC prevê a delegação de poderes ao Relator para, em substituição ao Colegiado, prover o recurso especial ou negar-lhe provimento, em determinadas hipóteses, possibilitando a revisão judicial por intermédio de agravo no recurso especial, especialmente quando há superveniente modificação da base fática". (AgRg no REsp $\mathrm{n}^{\circ}$ 260.041-BA, $3^{\mathrm{a}}$ Turma, Rel. Min. Nancy Andrighi, j. 24.6.2002, DJ 26.8.2002)

"Não usurpa competência do órgão colegiado o Relator que dá, monocraticamente, provimento a recurso contra decisão em manifesto confronto com jurisprudência dominante do Supremo Tribunal Federal ou deste Superior Tribunal de Justiça, tampouco afronta o devido processo legal, pois age em estrita observância à norma do art. 557, $\S 1^{\circ}$-A, do Código de Processo Civil”. (AgRg no REsp n ${ }^{\circ}$ 509.830-RJ, $6^{\text {a }}$ Turma, Rel. Min. Hélio Quaglia Barbosa, j. 15.8.2006, DJ 27.11.2006)
} 
'presenta' e que a vontade manifestada pelo relator não é a sua, mas a do órgão que integra e que dele recebeu delegação",344.

Opõem-se a este entendimento Fabiano Carvalho, Milton Luiz Pereira ${ }^{345}$ e Athos Gusmão Carneiro $^{346}$, primeiro porque a decisão singular não pode ser considerada mera atividade decisória preambular do órgão colegiado, a quem competiria a decisão "principal" e segundo porque a atividade decisória do relator somente estará sujeita à fiscalização do órgão coletivo se interposto o agravo interno de que tratam os artigos 545 e 557, §1 ${ }^{\circ}$, do Código de Processo Civil. Se esse recurso não for interposto, a decisão individual do relator não será levada a conhecimento do colegiado e transitará em julgado ${ }^{347}$.

Oportunas são as palavras de Fabiano Carvalho sobre o tema: "O art. 557 do CPC atribui ao relator poderes para exercer atos decisórios no âmbito recursal. Trata-se de competência funcional, porque o relator, ao receber o recurso e verificar que não devera ter seguimento, ou, então, que a decisão recorrida é contraria à orientação dos tribunais superiores, julgá-lo-á sem a participação do órgão coletivo. Pode-se dizer que o relator tem competência funcional horizontal uma vez que o recurso tramita no mesmo grau de jurisdição, e ele, o relator, pertence ao órgão colegiado, que também pode ser competente para julgar esse recurso" 348 .

Nessa linha de ideias, é inequívoco que, mesmo assegurada a intervenção do colegiado, o relator - como órgão individualizado do tribunal - julga, e, ao julgar, exerce poder jurisdicional que lhe foi outorgado por lei ${ }^{349}$. Na visão de Maria Berenice Dias, "o relator, em casos tais, não estará decidindo por ‘delegação' do colegiado a que pertence, mas sim exerce poder jurisdicional que lhe foi outorgado por lei" ${ }^{350}$.

\footnotetext{
${ }^{344}$ SLAIBI FILHO, Nagib. Op. cit., p. 98.

${ }^{345}$ PEREIRA, Milton Luiz. Op. cit., p. 377/378

${ }^{346}$ CARNEIRO, Athos Gusmão. Op. cit.,, p. 14.

${ }^{347}$ CARVALHO, Fabiano. Op. cit., p.51

${ }^{348}$ Idem, p.52

${ }^{349}$ CARNEIRO, Athos Gusmão. Op. cit., p. 14

350 DIAS, Maria Berenice. As decisões monocráticas do art. 557 do CPC. Disponivel em http://www.mariaberenice.com.br/uploads/4___as_decis\%F5es_monocr\%E1ticas_do_art.557_do_cpc_-_si.pdf. Acesso em 13.6.2012.
} 
Questão interessante foi abordada por Izaías Batista de Araújo ${ }^{351}$, para quem o relator que julga isoladamente mérito do recurso fica, salvo no caso de juízo de retratação, impedido de participar do julgamento dos recursos que forem interpostos naquele processo, nos termos do artigo 134, III, do Código de Processo Civil ${ }^{352}$. Defende que "se não houver a distribuição do feito para outro relator, tal objetivo restara prejudicado, pois sendo o mesmo Ministro a conduzir o voto e o julgamento do agravo perante a Turma, na verdade não se estará implementando revisão alguma”.

Discordamos do entendimento exposto pelo autor, já que o art. 134, III, do Código de Processo Civil dispõe que é defeso ao juiz exercer suas funções no processo contencioso ou voluntário que conheceu em primeiro grau de jurisdição, tendo-lhe proferido sentença ou decisão; quer a legislação impedir que o juiz que tenha sido promovido para o tribunal julgue, em grau de recurso, causa em que tenha oficiado e decidido em grau de jurisdição inferior ${ }^{353}$ 354 .

\section{Faculdade ou dever do relator?}

O caput do artigo 557 do Código de Processo Civil prescreve que "O relator negará seguimento a recurso manifestamente inadmissível, improcedente, prejudicado ou em confronto com súmula ou com jurisprudência dominante do respectivo tribunal, do Supremo Tribunal Federal, ou de Tribunal Superior.”. Diante da redação do dispositivo surge então uma dúvida: o julgamento antecipado do recurso por decisão monocrática seria um poder ou um dever do relator? ${ }^{355}$

\footnotetext{
${ }_{351}^{351}$ ARAÚJO, Izaías Batista de. Op. cit., p.363

352 Art. 134. É defeso ao juiz exercer as suas funções no processo contencioso ou voluntário: (...) III - que conheceu em primeiro grau de jurisdição, tendo-lhe proferido sentença ou decisão.

${ }^{353}$ Como se sabe, a magistratura é organizada em carreira, de modo que os juízes iniciam suas atividades em cargos inferiores e podem ter acesso a cargos mais elevados segundo critérios de promoção, atendidas as normas do art. 93, II, da Constituição Federal.

${ }^{354}$ Mencionem-se as ponderações de Fabiano Carvalho sobre o tema: "O equivoco fundamental no raciocínio da doutrina que sustenta impedimento do relator, ao julgar monocraticamente o mérito de recurso, reside na circunstancia de considerar o agravo do $\S 1^{\circ}$ do art. 557 como recurso a ser julgado por outro órgão de jurisdição". (CARVALHO, Fabiano. Op. cit., p. 56).

${ }_{355}$ Cabe, aqui, uma ressalva. Como veremos nos capítulos seguintes, não se trata, a rigor, de negativa de "seguimento", mas de negativa de "provimento". Isto porque o relator não apenas deixa de encaminhar o recurso
} 
Parte da doutrina ${ }^{356}$ entende que a imperatividade contida na expressão verbal "negará seguimento" leva à conclusão de que não se trata de faculdade, mas de verdadeiro dever-poder atribuído ao magistrado. Isto porque, cabe ao relator zelar pela efetividade do processo, "inclusive antecipando as fases procedimentais em cada caso, tanto quanto juridicamente possível, e desde logo conhecer e resolver as questões, pois o processo é instrumento e não o fim da realização do Direito",357.

Comentando as alterações promovidas pela Lei n 9.135/95, Athos Gusmão Carneiro ponderou que (...) "Como vemos, foi notavelmente ampliada a competência atribuída ao relator em nível monocrático: não apenas "poderá”, mas “deverá” examinar preliminarmente se concorrem os requisitos de admissibilidade de qualquer recurso (...) ${ }^{\text {,358 }}$.

Diz Maria Berenice Dias que a norma "além de ter autorizado o acolhimento in limine do recurso (dizendo: o relator poderá dar provimento ao recurso), não outorga ao relator, simplesmente, a faculdade de negar seguimento ao recurso (dizia: o relator poderá indeferi-lo), mas impôs-lhe o dever de assim agir, dizendo agora: o relator negará seguimento ao recurso" 359 . A autora defende que quando o relator encaminha ao órgão colegiado um recurso que se insere em uma das hipóteses do artigo 557 do Código, não estará apenas abrindo mão de uma faculdade legal, mas, sim, descumprindo um dever decorrente de lei.

Comunga do entendimento de que o é dever e não de faculdade do relator, Fabiano Carvalho. $\mathrm{O}$ autor defende que o relator, quando entender que o recurso enquadra-se em uma das hipóteses que constam do caput do artigo 557 do Código de Processo Civil, tem o dever de negar-lhe seguimento: “ocorrendo uma dessas hipóteses e sob o princípio do seu livre convencimento, (o relator) deverá julgar o recurso sem a participação do órgão colegiado, fundamentando devidamente sua decisão. Não ocorrendo uma das hipóteses ut supra, é seu

ao Órgão Colegiado ao qual em principio é dirigido, mas declara que não procede a própria pretensão recursal (CARNEIRO, Athos Gusmão. Op. cit., p. 17).

${ }^{356}$ SLAIBI FILHO, Nagib. Op. cit., p. 104 e ARENHART, Sérgio Cruz. Op. cit., p. 43

${ }^{357}$ SLAIBI FILHO, Nagib. Op. cit., p. 98.

${ }^{358}$ CARNEIRO, Athos Gusmão. Op. cit., p. 13.

${ }^{359}$ DIAS, Maria Berenice, Op. cit. 
dever tomar todas as providências procedimentais para que o recurso tenha seu normal tramite, devendo, pois, ser julgado pelo órgão competente" 360 .

Sérgio Bermudes, ao analisar o caput do art. 557 do CPC, afirma que, embora a norma seja imperativa, não haverá sanção para o relator que colocar o recurso em pauta quando deveria negar-lhe seguimento, mesmo porque "seria absurdo restituir o recurso ao relator para que ele lhe negasse seguimento" 361 .

Cândido Rangel Dinamarco lembra que a redação do caput do artigo 557 do Código de Processo Civil vem da Reforma de 1995 e que a Lei n 9.756/98 limitou-se a reproduzi-la. O autor ressalta que, além de, à primeira vista, a redação insinuar obrigatoriedade, o emprego do advérbio manifestamente obriga o relator a abster-se de julgar de plano sempre que não veja uma situação manifesta, isto é, límpida e indiscutível ${ }^{362}$.

Athos Gusmão Carneiro faz ressalva de que a imperatividade da norma é relativa, já que em determinados casos é conveniente - seja pela relevância do tema no aspecto jurídico ou em suas repercussões sociais - que o órgão colegiado se pronuncie sobre a questão controversa levada a sua apreciação. ${ }^{363}$ Em segundo lugar, a imperatividade apresenta-se relativa, porquanto, mesmo quando ao relator pareça induvidoso o acerto do provimento recorrido tanto no exame dos fatos, como no das questiones juris, ainda assim, em determinados casos, apresentar-se-á conveniente (...) que sobre a lide se pronuncie, desde logo o colegiado (...).

No sentido de que se cuida de faculdade, e não de obrigação imperativa opinam Nelson Nery Jr. ${ }^{364}$, Nelson Luiz Pinto ${ }^{365}$ e Estefânia Viveiros; para esta autora a expressão "negar seguimento" consignada no caput do artigo 557 do Código de Processo Civil representa uma

\footnotetext{
${ }^{360}$ CARVALHO, Fabiano. Op. cit., p. 65.

${ }^{361}$ MIRANDA, Pontes de. Comentários ao Código de Processo Civil. 3. Ed. Atual por Sérgio Bermudes. Rio de Janeiro: Forense, 1999, t. 7, p. 228.

362 DINAMARCO, Candido Rangel. O relator... Op. cit., p.132.

363 CARNEIRO, Athos Gusmão. Op. cit., p. .17

${ }^{364}$ NERY JUNIOR, Nelson. Código de Processo Civil Comentado e Legislação Extravagante. 9a ed., São Paulo: Editora Revista dos Tribunais, 2006.

${ }^{365}$ PINTO, Nelson Luiz. Manual dos recursos cíveis. $2^{\mathrm{a}}$ ed., São Paulo: Malheiros, 2000, p. 210.
} 
faculdade do relator "porque concede a ele o poder de decidir se a controvérsia do caso merece ser levada a conhecimento dos seus pares, seja pela repercussão social ou pela relevância que o tema impõe, ou deva ser decidida monocraticamente pelo próprio relator" ${ }^{, 366}$.

Quem também defende o caráter de faculdade da expressão "negará seguimento" que consta do caput do art. 557 do Código é José Carlos Salles, para quem a norma em exame, embora possa parecer imperativa em um primeiro momento, "não pode ser interpretada por essa forma, porque se fosse tal exegese levaria à sua inconstitucionalidade, por cerceamento da ampla defesa, assegurada pelo art. $5^{\circ}, \mathrm{LV}$, da CF"367.

Ainda que entenda tratar-se de mera faculdade, Accácio Cambi defende que caso presentes os pressupostos do art. 557 do CPC, o relator não poderia perder a oportunidade de aplicá-lo, contribuindo, assim, para a agilização da prestação jurisdicional ${ }^{368}$.

Já no que toca ao $\S 1^{\circ}$-A do artigo 557 do Código de Processo Civil, o qual estabelece que o relator poderá dar provimento ao recurso nos casos em que especifica, Cândido Rangel Dinamarco $^{369}$ leciona que "o legislador quis deixar a prudente arbítrio do próprio relator a opção entre julgar por si próprio, monocraticamente, ou encaminhar o caso ao colegiado. Naturalmente, essa opção dependerá sempre do grau de convicção do relator, a quem competirá, com honestidade profissional, abster-se de julgar quando sentir que a matéria não é tão segura que legitime esses verdadeiros atalhos procedimentais instituídos pela lei."370.

Para Fabiano Carvalho, a disposição contida no $§ 1^{\circ}$-A do artigo 557 do Código de Processo Civil deve ser interpretado como autorização, de modo que o relator dará

\footnotetext{
${ }^{366}$ VIVEIROS, Estefânia. Op. cit., p. 70

${ }^{367}$ SALLES, José Carlos Moraes, apud CARVALHO, Fabiano. Op. cit., p.62

${ }^{368}$ CAMBI, Accácio. Atribuição inovadora concedida ao relator: negar seguimento ou dar provimento ao recurso monocraticamente. Artigo 557 do código de processo civil. Doutrina ADCOAS, São Paulo: Esplanada, vol. 6, jun./2001, p. 169.

${ }_{369}$ DINAMARCO, Candido Rangel. O relator... Op. cit., p. 132.

${ }^{370} \mathrm{O}$ autor lembra, ainda, que na redação das normas "que ampliam os poderes do relator nos tribunais tomou-se o constante cuidado de empregar o verbo poder, não o verbo dever (art. 120, par; 544, $\S 3^{\circ}$; art. 557, $\S 1^{\circ}$-A). Também não se disse que o relator julgara de plano o conflito de competência, ou provera desde logo o recurso especial etc. - o que equivaleria s criar-lhe obrigatoriedades". (CARVALHO, Fabiano. Op. cit., p.63)
} 
provimento a recurso somente quando a decisão recorrida estiver em divergência com súmula ou jurisprudência do Supremo Tribunal Federal ou do Superior Tribunal de Justiça ${ }^{371}$.

\section{Alcance da decisão do relator}

O julgamento do recurso sem a participação dos demais membros do colegiado ocorre nas hipóteses previstas no artigo 557 do Código de Processo Civil.

Dúvida que surgiu dizia respeito à aplicação do dispositivo nos processos regidos por outras normas que sejam omissas a respeito, como ocorre com o Código de Processo Penal e a Lei Federal no 8.038/90. A questão já foi pacificada pelo Supremo Tribunal Federal que, em julgamento realizado em 2002, consolidou o entendimento de que a possibilidade de o Relator julgar monocraticamente recursos estende-se aos processos em que a sistemática do Código de Processo Civil é aplicada, ainda que de forma subsidiária ${ }^{372}$.

Outra questão refere-se à possibilidade de o relator apreciar monocraticamente o recurso se não estiver convencido de suas razões e seguro de que o recurso amolda-se a uma das categorias previstas no artigo 557, caput ou $§ 1^{\circ}$-A, do Código de Processo Civil.

O entendimento doutrinário que predomina é no sentido de que o relator deverá submeter o tema à apreciação do colegiado sempre que possuir dúvida a respeito da aplicabilidade do artigo 557, caput ou $§ 1^{\circ}$-A, do Código de Processo Civil ${ }^{373}$. Cândido Rangel Dinamarco sintetiza o entendimento predominante ao afirmar que a opção pelo julgamento monocrático "dependerá sempre do grau de convicção do relator, a quem competirá, com honestidade profissional, abster-se de julgar quando sentir que a matéria não é tão segura que legitime esses verdadeiros atalhos procedimentais instituídos pela lei"374.

\footnotetext{
${ }^{371}$ CARVALHO, Fabiano. Op. cit., p. 68.

${ }^{372}$ STF, RE no 256.157/GO, rel. Min. Nelson Jobim, DJU 3.5.2002

${ }^{373}$ FILHO, Nagib Slabi. Notas sobre o art. 557 do CPC (competência do relator de prover e de negar seguimento a recurso). Revista Forense, Rio de Janeiro, v. 361, ano 98, p..98.

${ }^{374}$ CARNEIRO, Athos Gusmão. Poderes do Relator e Agravo Interno. Revista de Processo. N. 100, ano 25, p. 932, out./dez.2000. Editora dos Tribunais p. 15
} 
Mencione-se ainda que, como a atividade decisória do relator sem a participação do colegiado está adstrita às hipóteses previstas em lei, não pode o relator julgar com base apenas em sua convicção pessoal ${ }^{375}$; uma das hipóteses do artigo 557 , caput ou $§ 1^{\circ}$-A, do Código de Processo Civil deve se fazer presente.

Assim, se a questão se apresentar eivada de dúvida ou for objeto de controvérsia, o relator deve, a despeito de sua opinião pessoal, abster-se de apreciar o recurso nos termos do artigo 557, caput ou $\S 1^{\circ}$-A, do Código de Processo Civil, submetendo o recurso à análise do órgão colegiado $^{376}$. No entender de Gustavo Nogueira, decisão monocrática do relator proferida com base em convicções pessoas isoladas, que não encontra respaldo na jurisprudência do Tribunal respectivo ou de Tribunais Superiores, carecerá de legitimidade ${ }^{377}$.

Dúvida que surge é: e se for hipótese de aplicação do artigo 557, caput ou $\S 1^{\circ}$-A, do Código de Processo Civil, mas o entendimento do relator for divergente daquela do órgão colegiado? Nagib Slabi Filho pondera que, por razões de celeridade e de prestígio à jurisprudência, a melhor solução seria a de o relator antecipar, em sua decisão, aquilo que supõe viria a deliberar o colegiado, uma vez que a "expressão manifestamente improcedente exige do relator proceder à cognição que seria dada pela turma julgadora, em antevisão do que esta decidiria, e não em atenção ao entendimento próprio do relator, que é, no caso, como antes referido, delegado do colegiado, cujo poder "presenta", ${ }^{378}$. E complementa que o relator, ao prestigiar o entendimento do colegiado, poderá fazê-lo ressalvando-se com a clássica nota de que assim procede com a reserva do entendimento pessoal em contrário ${ }^{379}$.

\footnotetext{
${ }^{375}$ CIANCI, Mirna. A lei 9.756/1998 (CPC, artigos 544, par. $3^{\circ}$ e 557, pars. $1^{\circ}$ a $3^{\circ}$ ) e a ampliação dos poderes do relator, dez anos depois. Revista Brasileira de Direito Processual RDBPro. ano 16, n. 61, p. 111.

${ }^{376}$ CAMBI, Accácio. Atribuição inovadora concedida ao relator: negar seguimento ou dar provimento ao recurso monocraticamente. (Art. 557/CPC). Boletim Doutrina. n. 6, ano IV, p..166.

${ }^{377}$ NOGUEIRA, Gustavo Santana. Jurisprudência vinculante no direito norte-americano e no direito brasileiro. Revista de Processo. ano 33, n161, p. 102-110, jul./2008 São Paulo: Editora Revista dos Tribunais. O autor afirma que, no entanto, "há notícias de casos que foram julgados isoladamente pelo relator, sem nenhum precedente que embasasse essa decisão, e, nao raro, essas decisões monocráticas representam uma ofensa aos precedentes que justificariam a decisão isolada. (...)".

${ }^{378}$ FILHO, Nagib Slabi. Notas sobre o art. 557 do CPC (competência do relator de prover e de negar seguimento a recurso). Revista Forense, Rio de Janeiro, v. 361, ano 98, p. 105.

${ }^{379}$ Idem
} 
Questão delicada foi suscitada por Fabiano Carvalho ${ }^{380}$ e diz respeito à possibilidade de julgamento monocrático parcial do recurso, com base em alguma das hipóteses do art. 557, caput ou $\S 1^{\circ}$-A, levando-se em consideração que, a despeito de poder haver mais de uma questão a ser analisada pelo julgador, o pronunciamento emitido é considerado uno, indivisível e incindível.

$\mathrm{O}$ autor exemplifica com a hipótese em que uma primeira questão aventada no recurso está sumulada pelos tribunais superiores, mas uma questão distinta não se enquadra em nenhuma das hipóteses contempladas no artigo 557 do Código de Processo Civil. Conclui que, neste caso, o relator não poderá julgar individualmente o recurso por lhe faltar competência funcional $^{381}$.

\subsection{Reexame necessário}

E com relação ao alcance da decisão nos casos de reexame necessário, doutrina e jurisprudência admitem possa o relator julgá-lo como se fosse referido no art. 557, caput e $\S 1^{\circ}$-A do Código de Processo Civil ${ }^{382}$.

Sob a denominação de reexame necessário, vem sido acolhida a hipótese de as sentenças proferidas contra a Fazenda Publica estarem sujeitas, obrigatoriamente, ao reexame e à confirmação pelo órgão de segunda instância, para produzirem efeitos.

Atualmente, há discussão acerca da natureza jurídica do reexame, sendo que prevalece a teoria de que o duplo grau obrigatório não é recurso, mas condição de eficácia da sentença.

\footnotetext{
${ }^{380}$ Poderes do relator nos recursos: art. 557 do CPC. São Paulo: Saraiva, 2008, p.73.

${ }^{381}$ Prossegue o autor em sua análise "Aceitar fragmentação da decisão judicial contribuiria para retardar o julgamento final da causa, porque, v.g., a parte valer-se-ia do agravo interno (art. 557, $\S 1^{\circ}$, do CPC) contra a decisão do relator que julgou em "parte" o recurso, paralisando todo o procedimento, até o julgamento final desse recurso pelo órgão colegiado. A decisão do agravo interno poderia, ainda, ensejar a interposição de outros recursos, prolongando ainda mais o desfecho do processo. (...) Ajunte-se a tudo isso o principio da concentração, segundo o qual os atos processuais atribuídos aos órgãos da jurisdição deverão ser realizados sem demora, procurando-se abreviar os prazos e agrupar em um mesmo ato todas as diligencias que for preciso. Dessa perspectiva, nao é difícil afirmar que o ponto fundamental do principio da concentração é a unicidade do julgamento unipessoal do recurso.

${ }^{382}$ FILHO, Nagib Slabi. Notas sobre o art. 557 do CPC (competência do relator de prover e de negar seguimento a recurso). Revista Forense, Rio de Janeiro, v. 361, ano 98, p.100.
} 
No código de 1939, o reexame necessário era tratado por "apelação ex officio" e era cabível nas causas em que fosse declarada a nulidade do casamento, fosse homologado o desquite amigável e nas sentenças proferidas contra a União, o Estado ou o Município.

Buzaid, responsável pela elaboração do anteprojeto convertido no Código de Processo Civil de 1973, era avesso ao instituto. No anteprojeto, Buzaid afastou a obrigatoriedade do reexame necessário, mesmo em contraposição às vozes que defendiam a sua permanência. Entretanto, durante a tramitação do projeto, o dispositivo foi incluído na redação do Código de $1973^{383}$.

Assim, o Código de Processo Civil de 1973 previu que estavam sujeitas ao duplo grau as sentenças que anulassem o casamento, que fossem proferidas em face da União, Estados ou do Município e aquelas que julgassem improcedente a execução de dívida ativa da Fazenda Publica. Segundo o diploma, o juiz determinava a remessa dos autos ao tribunal ou o tribunal poderia os avocar.

O regime jurídico do reexame necessário passou por alterações durante a segunda fase de reformas do Código, a denominada pela doutrina de "Reforma da Reforma", por meio da Lei 10.352/01.

Eliminou-se o duplo grau obrigatório em relação às sentenças de anulação de casamento, já que tal disposição havia perdido o sentido diante da previsão da possibilidade de divórcio no ordenamento jurídico.

Houve, também, uma ampliação à proteção da Fazenda Pública. A remessa oficial, que era necessária somente em sentenças contrárias à União, Estados e Municípios, passou a abranger toda e qualquer pessoa jurídica de direito público.

${ }^{383}$ CRUZ E TUCCI, José Rogério. Lineamentos da Nova Reforma do CPC, São Paulo: RT, 2002. 
Criaram-se duas hipóteses de dispensa da remessa necessária: (i) sentenças em que a condenação ou o valor controvertido não excederem 60 salários mínimos, bem como em face da procedência dos embargos de devedor na execução da divida ativa de igual valor; e (ii) sentença fundamentada em orientação jurisprudencial do plenário ou em súmula do STF ou, ainda, em súmula de tribunal superior competente.

E, no que tange à remessa oficial, a doutrina entende que, à luz do princípio da economia e da utilidade do processo, a decisão do relator que aprecie monocraticamente a remessa oficial não se mostra ofensiva à lei. Mesmo porque, caso contrário, considerando-se que a maior parte dos recursos que abarrotam os tribunais envolvem o Poder Público e que as teses costumam ser repetidas ${ }^{384}$, a inovação introduzida pelo artigo 557 do Código de Processo Civil tornar-se-ia inócua, até porque seus fins precípuos são o de reduzir a carga de trabalho do órgão colegiado e o de abreviar as pautas de julgamento.

Vale acrescentar que o Superior Tribunal de Justiça consolidou o entendimento de que a disciplina prevista no artigo. 557 do Código de Processo Civil deve abranger os recursos propriamente ditos arrolados no artigo 496 do Código, bem como a remessa necessária prevista no artigo 475, conforme o enunciado n 253 de sua Súmula: "O art. 557 do CPC, que autoriza o relator a decidir o recurso, alcança o reexame necessário”.

Segundo entendimento do Ministro Adhemar Maciel no julgamento do Recurso Especial $\mathrm{n}^{\circ}$ 156.311/BA: “(...) o novo art. 557 do CPC tem como escopo desobstruir as pautas dos tribunais, a fim de que as ações e os recursos que realmente precisam ser julgados por órgão colegiado posam ser apreciados o quanto antes possível. Por isso, os recursos intempestivos, incabíveis, desertos e contrários à jurisprudência consolidada do segundo grau ou nos tribunais superiores deverão ser julgados imediatamente pelo próprio relator, através de

\footnotetext{
384 "Cada vez mais o Poder Publico vem se posicionando como parte nas causas oferecidas ao julgamento dos órgãos judiciários em todas as instancias. (...) E assim é porque tal é exigido pelo ordenamento jurídico execuções fiscais, responsabilidade civil do Estado, desapropriações etc. - e pelos administrados que somente encontram no Poder Judiciário providencial socorro em face da lamentável ineficácia estatal - demandas sobre a omissão de prestação de serviços educacionais e de seguridade social (saúde e previdência) - e, o que é mais sintomático, nas causa deflagradas pela própria Administração Publica, que, desvestindo-se de poder de autoexecutoriedade, vai buscar na Toga a legitimidade que desconfia que os cidadãos não encontram nos seus atos (....)". (FILHO, Nagib Slabi. Notas sobre o art. 557 do CPC (competência do relator de prover e de negar seguimento a recurso). Revista Forense, Rio de Janeiro, v. 361, ano 98, p.100)
} 
decisão singular, acarretando o tão desejado esvaziamento das pautas. Prestigiou-se, portanto, o princípio da celeridade processual, que norteiam o direito processual moderno. Por isso, tal dispositivo merece uma exegese à luz do método de interpretação teleológica, sob pena de não cumprir a missão que o legislador lhe confiou, qual seja, liberar as pautas para as ações originárias e os recursos que tratam de questões ainda não solucionadas pelos tribunais. Portanto, o vocábulo 'recurso' inserto no art. 557 do CPC deve ser interpretado em sentido amplo, abrangendo os recursos - propriamente ditos - arrolados no artigo 496 do CPC, bem como a remessa necessária, prevista no art. 475 do CPC"385.

A propósito, o entendimento esposado pelo Min Fernando Gonçalves quando do julgamento do Recurso Especial no 190.096: "A tese de que somente para os recursos catalogados no art. 496 do CPC teria aplicabilidade a norma do art. 557 é, data venia, inconsistente. Primeiro, porque a remessa oficial, substituta do recurso de ofício, conforme unanimidade dos autores, é um "quase-recurso", ou procedimento análogo. (BUZAID, FREDERICO MARQUES, BARBOSA MOREIRA, MOACYR AMARAL DOS SANTOS). Tem os efeitos devolutivo e suspensivo e se lhe aplicam os princípios e normas regentes da apelação. Em segundo lugar, o rol do art. 496 do CPC não é exaustivo, porquanto dele não constam todos os recursos previstos no próprio código ou em leis especiais (Comentários ao CPC - BARBOSA MOREIRA - FORENSE - VOL. V - pág. 278 - 1998). Não há, então, porque atribuir-se à remessa de ofício maior prestígio que ao recurso voluntário, negando-se ao relator uma apreciação conjunta de todo o problema aflorado e a verificação da observância das formalidades legais próprias como, aliás, dispunha o Código de 1939, em relação ao recurso de ofício interposto da sentença proferida em ação de desquite. O processo, como lembra HUMBERTO THEODORO, é um caminhar sempre para frente. Verdadeiro contrassenso, máxime diante da recente alteração introduzida pela Lei $\mathrm{n}^{\circ}$ 9.756, de 17 de dezembro de 1998, do CPC, facultando ao relator, em nome do órgão fracionário, dar provimento a recurso, nas condições especificadas, além de outras providências desburocratizantes, visando, antes de tudo, a celeridade da prestação jurisdicional. Seria contraditório que o recurso voluntário, munido de razões e contrarrazões, possa ser provido ou

${ }^{385}$ Resp 156.311/BA, 2a Turma, DJ 16/03/1998 p. 102. 
ter seguimento negado e a remessa oficial, interposta apenas para verificação, normalmente, da observância de formalidades legais próprias, reclamasse o julgado colegiado."386 .

Este, todavia, nem sempre foi o entendimento jurisprudencial. José Miguel Garcia Medina $^{387}$ traz à luz precedente do Superior Tribunal de Justiça (Resp 104.106), no qual se sustentou que, mesmo que o recurso interposto reunisse qualquer um dos requisitos que autorizassem o relator a negar-lhe seguimento, estando o feito sujeito ao reexame necessário, tornar-se-ia obrigatória a apreciação pelo colegiado competente, porque nos termos do artigo 475, caput, do Código de Processo Civil, a sentença recorrida só produzira efeito "depois de confirmada pelo tribunal".

Esse entendimento, como visto, restou superado pela própria jurisprudência do Superior Tribunal de Justiça.

O entendimento pacificado na doutrina e jurisprudência, pois, é de que o relator pode se valer do art. 557 do Código de Processo Civil para apreciar monocraticamente a remessa oficial sem ofensa à norma legal ${ }^{388}$.

Mencione-se por fim que a partir do advento da Lei $\mathrm{n}^{\circ} 10.352$, de 26 de dezembro de 2001, a qual acrescentou o parágrafo $3^{\circ}$ ao artigo 475 do Código de Processo Civil, afastou-se a exigência do duplo grau de jurisdição obrigatório para a sentença proferida em conformidade com a jurisprudência do plenário do Supremo Tribunal Federal ou com entendimento sumulado do tribunal superior competente. Assim, nessa hipótese, o relator não poderá reexaminar monocraticamente a sentença, mas apenas declarar que, diante da ausência de interposição de recurso e não sendo caso de reexame necessário, a sentença transitou em julgado.

\footnotetext{
${ }^{386}$ Resp 190096/DF, 6a Turma, DJ 21/06/1999 p. 208, RSSTJ vol. 19 p. 183, RSTJ vol. 144 p. 503

${ }^{387} \mathrm{O}$ relator, a jurisprudência e os recursos p. 368-369.

${ }^{388}$ Mencione-se que a Advocacia Geral da União editou a Súmula Administrativa n. 11 de 19 de abril de 2002, com o seguinte teor: "A faculdade, prevista no art. 557 do CPC, de se negar seguimento, monocraticamente, a recurso manifestamente inadmissível, improcedente, prejudicado ou em confronto com súmula ou com jurisprudência dominante do respectivo tribunal, do Supremo Tribunal Federal, ou dos Tribunais Superiores, alcança também a remessa necessária."
} 


\section{Motivação da decisão monocrática}

A suficiente fundamentação das decisões monocráticas proferidas com base no disposto no artigo 557 do Código de Processo Civil é um aspecto a que não se tem dado a devida importância. Na prática, parcela considerável das decisões monocráticas limita-se a afirmar que o inconformismo recursal da parte não encontra (ou encontra, no caso do $\S 1^{\circ}$-A da norma) respaldo em jurisprudência dominante, sem, contudo, trazer a lume, ainda que exemplificativamente, os julgados que demonstram a reiterada conduta do tribunal com relação ao tema em debate ${ }^{389}$.

Escapa dos julgadores que o relator, ao demonstrar de forma clara e explícita, seja no afastamento, seja no acolhimento do recurso, as razões de seu entendimento e, principalmente, que não seria outra a decisão caso o recurso fosse encaminhado para apreciação do colegiado e/ou dos tribunais superiores, desestimula a parte sucumbente a recorrer, posto já ter restado evidenciada a improvável reforma na decisão, agilizando-se, de fato, o trâmite processual ${ }^{390}$.

O artigo 557 do Código de Processo Civil, embora tenha por objetivos aliviar a carga de trabalho dos colegiados e acelerar o andamento do processo, pode ter justamente o efeito contrário, ao dar ensejo a diversos recursos que "não se encontram 'programados' à ordem natural do processo" ${ }^{, 391}$, como os embargos de declaração opostos em face da decisão do relator e a impugnação perante o colegiado, mediante agravo de que trata o $\S 1^{\circ}$ do artigo $557^{392}$.

Como bem observou Barbosa Moreira: “(...) será arriscado supor que sirva de tranquilizante eficaz a multiplicação de casos em que se outorga ao relator a competência para

\footnotetext{
${ }^{389}$ CIANCI, Mirna. Op. cit.,, p. 114/115.

${ }^{390}$ CAMBI, Accácio. Atribuição inovadora concedida ao relator: negar seguimento ou dar provimento ao recurso monocraticamente. Artigo 557 do código de processo civil. Doutrina ADCOAS, São Paulo: Esplanada, vol. 6, jun./2001, p. 166.

${ }^{391}$ COSTA, Hélio Rubens Batista Ribeiro. Op. cit., p. 119.

${ }^{392}$ Lembramos que o legislador procurou desestimular a interposição do agravo, cominando multa nos casos em que o recurso for "manifestamente inadmissível ou infundado", a cujo depósito se condiciona a interposição de qualquer outro recurso.
} 
decidir só por si. É que, conforme se registrou, sua decisão poderá ser impugnada perante o colegiado, de sorte que se criarão outras tantas oportunidades de recorrer". Prossegue afirmando que "Dificilmente passará despercebida aos olhos de qualquer observador, aliás, a quantidade de agravos, impropriamente ditos "regimentais", que costumam inchar a quota de trabalho dos tribunais brasileiros"393.

Claro está, portanto, que o bom resultado prático dos julgamentos monocráticos de recursos, nos moldes do artigo 557 do Código de Processo Civil, dependerá da atuação dos vencidos em anuir à decisão singular, abstendo-se, por conseguinte, de provocar o colegiado pela interposição do agravo interno ${ }^{394}$.

Nesse contexto, a motivação das decisões monocráticas é fundamental para reduzir o inconformismo da parte diante de uma derrota imposta por ato exclusivo do relator, evitando que aquele que se sinta injustiçado pleiteie que se ouçam também os membros do órgão colegiado.

Desse modo, o relator, ao proferir a decisão monocrática, deve demonstrar que a orientação jurisprudencial está sedimentada através de menção dos precedentes existentes, não bastando a mera alusão à existência de jurisprudência dominante sobre o tema. A respeito, decidiu o Superior Tribunal de Justiça que "ofende o art. 557, caput, do CPC a decisão monocrática que se limita a afirmar a conformidade da decisão impugnada com o entendimento dos Tribunais, deixando de proceder à indispensável demonstração da existência de orientação sedimentada no âmbito daquela Corte ou de Tribunal Superior a respaldar a tese adotada"395.

\footnotetext{
${ }^{393} \mathrm{O}$ autor conclui que são necessários dados estatísticos para que se possa dizer se grande parte das decisões de relatores permanece irrecorrida, e por conseguinte a sobrecarga ainda é menor do que seria se todos os feitos houvessem por força de chegar ao colegiado. (MOREIRA, José Carlos Barbosa. Reformas do CPC em matéria de recursos. Revista da EMERJ, Rio de Janeiro, v.4, n.13, 2001, p. 59/60).

${ }^{394}$ VIVEIROS, Estefânia. Op. cit., p. 18

${ }^{395}$ Consta do voto que "No presente caso, a decisão monocrática que negou provimento à apelação, com amparo no art. 557 do CPC, limitou-se a afirmar que a decisão impugnada "ajusta-se (...) à orientação dominante neste Tribunal e no Eg. Superior Tribunal de Justiça sobre a matéria", transcrevendo trecho de julgado daquela Corte (fl. 138), sem, contudo, proceder à indispensável demonstração da existência de orientação sedimentada no âmbito daquela Corte ou de Tribunal Superior a respaldar a tese adotada, com o que restaram desatendidas as exigências do art. 557, caput, do CPC. Também o acórdão que julgou o agravo interno deixou de indicar os fundamentos pelos quais considerou legítima, no caso, a aplicação do art. 557 do CPC (fl. 150), não se podendo
} 
Quanto melhor for a fundamentação da decisão monocrática pelo relator, maior será a conformidade das partes interessadas com decisão a elas desfavorável, fator decisivo para que o aumento dos poderes do relator possa contribuir para que a prestação jurisdicional seja mais célere e eficiente ${ }^{396}$.

cogitar, assim, do suprimento da irregularidade". (REsp n 617.471-SE, 1a Turma, Rel. Min. Teori Albino Zavascki, j. 3.6.2004, DJ 21.6.2004).

${ }^{396}$ DANTAS, Ana Carolina de Araújo. Embargos declaratórios: da possibilidade de interposição em face de decisão monocrático do relator proferida com fulcro no artigo 557 do CPC. IOB - Repertório de Jurisprudência: Civil, Processual, Penal e Comercial, São Paulo, v.3, n.8, abr. 2011, p. 307. 


\section{CAPÍTULO 7 - IMPUGNAÇÃO DA DECISÃO MONOCRÁTICA}

\section{Agravo}

A lei opôs, como contrapartida de segurança, um mecanismo que lhe possibilita submeter a decisão do relator à apreciação do órgão colegiado ${ }^{397}$. O parágrafo $1^{\circ}$ do artigo 557 do Código de Processo Civil assim dispõe: "Da decisão caberá agravo, no prazo de cinco dias, ao órgão competente para o julgamento do recurso, e, se não houver retratação, o relator apresentará o processo em mesa, proferindo voto; provido o agravo, o recurso terá seguimento".

Na visão de Dinamarco, "esse cuidado (de outorgar à parte o poder de provocar a manifestação do colegiado competente, sempre que contrariada pela decisão singular do relator) homenageia a garantia constitucional do devido processo legal, na medida em que põe limite ao poder do relator em julgamentos que em princípio pertencem ao órgão colegiado; presta reverência também ao valor das garantias do juiz natural, porque os colegiados são o juiz natural dos recursos." ${ }^{, 398}$.

\subsection{Terminologia}

A previsão do agravo contra a decisão monocrática do relator teve origem no regimento interno dos tribunais, razão pela qual, por muito tempo, tais agravos foram chamados de "regimentais".

A propósito, importante mencionar que, diante do fato de que o agravo contra a decisão unipessoal atualmente encontra previsão expressa na lei processual, restou superada a discussão acerca da inconstitucionalidade do agravo que tinha por fonte o regimento interno de tribunal.

\footnotetext{
${ }^{397}$ TUCCI, José Rogério Cruz. Sobre a atividade decisória do relator do agravo de instrumento. Revista Forense. V. 338, ano 93, p..412.

${ }^{398}$ VIVEIROS, Estefânia. Agravo Interno no Superior Tribunal de Justiça e ampliação dos podres do relator. Universitas/jus. $n^{\circ} 7$, p..63.
} 
À época, parte da doutrina que defendia a inconstitucionalidade do agravo previsto em regimento interno, argumentava que recursos somente poderiam ser criados por lei federal e não por norma interna corporis de tribunal ${ }^{399}$. Já aqueles que entendiam ser constitucional o sucedâneo, como Moniz de Aragão $0^{400}$ e Feu Rosa ${ }^{401}$, arguiam que não se tratava propriamente de recurso, mas meio de se promover a integração da vontade do órgão colegiado do Tribunal ${ }^{402}$.

Com o advento da previsão legal e tendo em vista que a hipótese de cabimento representa um tertium genus relativamente ao agravo retido e ao agravo por instrumento, o agravo deixou de ter a denominação "regimental" e passou a ser denominado pela doutrina como "agravo nos próprios autos", "agravo inominado" 403 ou até mesmo "agravo de lei"

\subsection{Processamento}

O agravo deve ser interposto no prazo de cinco dias perante o tribunal de que faz parte o relator que decidiu monocraticamente o recurso. A contagem do prazo de cinco dias, regra geral, inicia-se com a intimação da decisão pelo órgão oficial, observado o disposto no artigo 184 do Código de Processo Civil.

O agravo processa-se nos mesmos autos do recurso que fora apreciado monocraticamente, sendo dispensadas para seu processamento a realização de preparo e o traslado de peças.

\footnotetext{
${ }^{399}$ FILHO, Nagib Slabi. Notas sobre o art. 557 do CPC (competência do relator de prover e de negar seguimento a recurso). Revista Forense, Rio de Janeiro, v. 361, ano 98, p. 99.

400 "Do agravo regimental" in Revista dos Tribunais, vol. 315, n 19 e segs., pp. 140 e segs

401 Agravo regimental", in Revista dos Tribunais, vol. 738, pp. 729 e segs

402 À propósito o julgamento do Agravo regimental em agravo de instrumento $\mathrm{n}^{\circ} 247.591-3-\mathrm{RS}$ pela $1^{\mathrm{a}}$ Turma do Supremo Tribunal Federal: “O agravo regimental, nao sendo recurso, mas meio de promover-se a integração da vontade do colegiado que o relator representa, nao é inconstitucional sob o fundamento de ofensa à competência da União para legislar sobre processo".

${ }^{403}$ RIBEIRO DA COSTA, Hélio Rubens Batista Ribeiro. A inconstitucionalidade da primeira parte do $\S 3 .^{\circ}$ do art. 544 do CPC e demais questões referentes ao julgamento monocrático dos recursos constitucionais. Revista do Instituto dos Advogados de São Paulo. ano 2, n. 4, p..119.

${ }^{404}$ Para Athos Gusmão Carneiro, “a denominação de 'agravo interno’ preconizada por J. E. Carreira Alvim (...) é muito mais adequada do que a de "agravo de lei” adotada em alguns tribunais (...)".CARNEIRO, Athos Gusmão. Poderes do Relator e Agravo Interno. Revista de Processo. N. 100, ano 25, p..20
} 
A lei não traz previsão de intimação da parte contrária para apresentar suas razões o que, como se verá, deu azo a debates doutrinários.

Além disso, o recurso deverá impugnar especificamente as razões declinadas pelo relator quando do julgamento singular do recurso, sendo vedado à parte limitar-se a reiterar os fundamentos do recurso que fora julgado singularmente.

\subsubsection{Juízo de retratação}

O $§ 1^{\circ}$ do artigo 557 do Código de Processo Civil prevê a possibilidade de o relator, ao analisar o agravo interposto contra sua decisão, acolher o recurso e se retratar, reconsiderando a sua decisão. A hipótese se justifica em razão da celeridade e efetividade que se espera do processo civil.

A hipótese não suscita grandes debates na doutrina, que se limitou a questionar se o relator poderia, ao se retratar, alterar o conteúdo da sua decisão singular. Isto é, se a decisão monocrática fora pela “inadmissibilidade" do recurso, se poderia o relator ao se retratar $e$ determinar o regular processamento do recurso, revogando seu julgamento unipessoal, poderia ele proferir nova decisão monocrática analisando o mérito do recurso ${ }^{405}$.

Não vemos qualquer óbice, desde que previstos os requisitos que autorizam o relator a proferir julgamento monocrático. Assim, retratando-se ele com relação ao cabimento do recurso, poderá ele, caso a hipótese se subsuma ao disposto no artigo 557 do Código de processo Civil, analisar os temas litigiosos, de direito material ou processual. No entanto, a análise do mérito recursal não autorize a aplicação do artigo 557 do Código de Processo Civil, deverá o relator levar o recurso ao, ao conhecimento e julgamento da Câmara ou Turma.

\footnotetext{
${ }^{405}$ CARNEIRO, Athos Gusmão. Poderes do Relator e Agravo Interno. Revista de Processo. N. 100, ano 25, p.
} 21. 


\subsubsection{Efeitos}

O agravo interno tempestivamente interposto no prazo de cinco dias será dotado de efeito suspensivo; caso não seja oposto ou o seja intempestivamente, a decisão monocrática transitará em julgado, "revestindo-se, em princípio, da mesma eficácia que teria a decisão colegiada, inclusive com os efeitos da coisa julgada material, se abordado o mérito"406.

\subsubsection{Aspectos polêmicos}

Primeiramente, de se ressaltar a posição dos tribunais superiores de que a interposição do agravo interno seria etapa necessária ao esgotamento prévio das vias recursais exigido pelo Supremo Tribunal Federal e pelos Tribunais Superiores como pressuposto para admissibilidade dos recursos cuja análise lhes compete. Nesse sentido, o entendimento dessas Cortes tem sido no sentido da obrigatoriedade de interposição do agravo na hipótese da parte possuir interesse em buscar a reanálise de matéria perante os Tribunais Superiores ${ }^{407}$. Torna-se necessária, assim, a interposição de agravo para o esgotamento prévio das instâncias ordinárias de modo a viabilizar o conhecimento de recurso especial e extraordinário.

Outro aspecto polêmico diz respeito à possibilidade de o relator negar seguimento ao agravo. Para alguns autores, o relator não pode negar seguimento, já que o $\S 1^{\circ}$ diz expressamente que, se não houver retratação, “o relator apresentará o processo em mesa". Para o autor, a expressão "apresentará" impõe dever funcional ao relator e aduz que seria "tautológico que o relator rejeitasse recurso do art. 557 com fundamento no próprio art. 557, negando-lhe o seguimento" ${ }^{, 408}$.

Mas a polêmica maior no que se refere à expressão "apresentará o processo em mesa" refere-se à desnecessidade de o relator pedir dia para o julgamento do agravo, afastando a

\footnotetext{
${ }^{406}$ CARNEIRO, Athos Gusmão. Poderes do Relator e Agravo Interno. Revista de Processo. N. 100, ano 25, p.20. ${ }^{407}$ NUNES, Dirle José Coelho. Colegialidade das Decisões dos Tribunais - Sua Visualização como princípio constitucional e do Cabimento de Interposição de Agravo Interno de Todas as Decisões Monocraticas do Relator. Revista IOB de Direito Civil e Processual Civil. Ano IX, n. 50, p .57

${ }^{408}$ FILHO, Nagib Slabi. Notas sobre o art. 557 do CPC (competência do relator de prover e de negar seguimento a recurso). Revista Forense, Rio de Janeiro, v. 361, ano 98, p. 100.
} 
inclusão em pauta e a possibilidade de sustentação oral. Nas palavras de Barbosa Moreira, "bem pode acontecer, portanto, que a parte vencedora nos termos da decisão do relator venha a ter sua vitória transformada em derrota, sem haver sido oficialmente avisada da interposição do agravo e do fato de que ele será julgado em determinada sessão. É uma sistemática que de maneira alguma se harmoniza com a garantia constitucional do contraditório e da ampla defesa (carta da Republica, art. 5, n. LV)" ${ }^{\circ 09}$.

Athos Gusmão Carneiro também defende a necessidade de inclusão do agravo em pauta "máxime nos casos em que o julgamento singular tenha sido "de mérito", ante a possibilidade de que o colegiado, em negando provimento ao agravo e, pois, confirmando a decisão do relator, venha a prolatar acordão de mérito " 410 .

Para Carmona, "pode-se estar diante de pura e simples supressão do direito das partes de sustentarem oralmente suas razões quando o julgamento monocrático (e posterior agravo) versar hipótese de recurso especial ou extraordinário!"411.

O mesmo entendimento é partilhado por Sérgio Cruz Arenhart, que afirma que “Talvez, o mais grave problema (...) diga com a inexistência de menção à necessidade de publicação em pauta, da data do julgamento. Se, como visto, o agravo não altera a natureza do recurso ordinário, então poderá caber, no procedimento da análise do recurso pela corte, momento para a sustentação oral. Todavia, uma vez que as partes não têm ciência oficial da data em que o recurso será levado à apreciação do colegiado, pode ocorrer que não se façam presentes à sessão, ainda que desejassem apresentar oralmente seus argumentos” ${ }^{\text {} 412}$.

\footnotetext{
${ }^{409}$ CIANCI, Mirna. A lei 9.756/1998 (CPC, artigos 544, par. $3^{\circ}$ e 557, pars. $1^{\circ}$ a $3^{\circ}$ ) e a ampliação dos poderes do relator, dez anos depois. Revista Brasileira de Direito Processual RDBPro. ano 16, n. 61, p. 106.

${ }^{410}$ CARNEIRO, Athos Gusmão. Poderes do Relator e Agravo Interno. Revista de Processo. N. 100, ano 25, p..22.

${ }^{411}$ CARMONA, Carlos Alberto. "O sistema recursal brasileiro: breve analise critica”. Aspectos polêmicos e atuais dos recursos. Coord. Eduardo Pellegrini de Arruda Alvim, Nelson Nery Jr. e Teresa Arruda Alvim Wambier. São Paulo: RT, 2000, p. 48.

${ }^{412}$ ARENHART, Sérgio Cruz. A nova postura do relator no julgamento dos recursos. Revista de Processo. n. 103 , ano 26, p..55.
} 
Todavia, a jurisprudência das Cortes Supremas firmou o entendimento de que a disposição não ofende o contraditório e o devido processo legal, como se pode notar do julgamento do RExt n 227.030 .

Por fim, mencione-se que há três situações possíveis decorrentes do julgamento do agravo pela Turma ou Câmara: (i) o colegiado não conhece do (v.g. por intempestivo ou inepto), de modo que fica mantida a decisão monocrática; (ii) o colegiado conhece do agravo, mas nega provimento a referido recurso; e (iii) o colegiado conhece do agravo e dá provimento ao recurso que, nos termos da lei, "terá seguimento"413.

Dúvida que surgiu foi no sentido de se poderia a Turma ou Câmara, ao dar provimento ao agravo, passar desde logo ao conhecimento e julgamento do recurso que havia sido monocraticamente apreciado.

Segundo Carlos Alberto Carmona, "duas interpretações são possíveis: a) o agravo introduzido pela Lei 9.756/98 teria o condão apenas de verificar se o relator, ao julgar monocraticamente, teria agido dentro das hipóteses legais (jurisprudência dominante, por exemplo), de tal sorte que o provimento do agravo serviria para desconstituir o julgamento, passando o recurso a ter processamento regular; e b) o agravo serviria para devolver ao órgão julgador a apreciação do recurso principal”414.

\section{A aplicação de multa nos casos de interposição de agravo manifestamente inadmissível ou infundado}

O artigo 557 do Código de Processo Civil prevê a possibilidade de cominação de multa para o litigante que interponha agravo "manifestamente inadmissível ou infundado" contra a decisão unipessoal do relator, $\left(\S 2^{\circ}\right)$ e impede a parte de interpor qualquer outro recurso enquanto não depositar o valor da multa imposta.

\footnotetext{
${ }^{413}$ VIVEIROS, Estefânia. Agravo Interno no Superior Tribunal de Justiça e ampliação dos podres do relator. Universitas/jus. $\mathrm{n}^{\circ}$ 7, p. $75 / 76$

${ }^{414}$ CARMONA, Carlos Alberto. "O sistema recursal brasileiro: breve analise critica". Aspectos polêmicos $e$ atuais dos recursos. Coord. Eduardo Pellegrini de Arruda Alvim, Nelson Nery Jr. e Teresa Arruda Alvim Wambier. São Paulo: RT, 2000, p. 47/48
} 
A multa tem por principal finalidade estimular a resignação da parte com a decisão monocrática e inibir a interposição de agravos protelatórios, penalizando o litigante de má fé que pretenda unicamente retardar o andamento do feito.

Não se pode, todavia, extrair interpretação que conduza à inexorabilidade de aplicação da sanção sempre que ao agravo se negar seguimento porque inadmissível ou infundado; a sanção apenas pode ser imposta se ocorrer situação particular que a decisão judicial deverá motivadamente explicitar.

E, como já dito, além da multa, a lei também condiciona a interposição de outros recursos ao deposito do respectivo valor. A constitucionalidade desta previsão foi questionada pela doutrina por constituir-se em obstáculo excessivo ao direito de recorrer. Conforme pondera Donaldo Armelin, "levada às suas últimas consequências essa cominação, o beneficiário da assistência jurídica e o insolvente civil não teriam mais como recorrer nos autos, sempre que punidos com a multa em tela" ${ }^{415}$.

Teresa Arruda Alvim Wambier considera que condicionar a interposição de qualquer recurso ao deposito da multa equivale a negar o acesso à justiça, acrescentando que revela-se fator de insegurança, “já que as expressões manifestamente inadmissível e infundado são, no fundo, conceitos indeterminados"

Oportunas, ainda, as palavras de José Carlos Barbosa Moreira: "A disposição é criticável por mais de um aspecto, a começar pela escolha da base de cálculo da multa: a essa altura, o valor da causa tem pouquíssima relevância, e nenhuma relação com o problema. Ajunte-se que a cláusula penal final cerceia com rigor excessivo o direito de recorrer" ${ }^{` 417}$.

\footnotetext{
${ }^{415}$ ARMELIN, Donaldo. "Apontamentos sobre as alterações ao Código de Processo Civil e à Lei 8.038/90, impostas pela Lei 9.756/98". Aspectos polêmicos e atuais dos recursos cíveis de acordo com a Lei 9.756/98. Coord. Teresa Arruda Alvim Wambier e Nelson Nery Jr., São Paulo: RT, 1999, p. 214

${ }^{416}$ Os agravos no CPC brasileiro. São Paulo: RT, 2006, p. 557

${ }^{417}$ MOREIRA, José Carlos Barbosa. Reformas Processuais e Poderes do Juiz. Revista de Direito do Tribunal de Justiça do Estado do Rio de Janeiro. n. 56, p..23/24.
} 
Sérgio Cruz Arenhart, todavia, manifesta entendimento contrário, afirmando que “(....) não há sentido em ter por inconstitucional a previsão. $O$ fato de a lei condicionar a interposição de recurso a certos requisitos é algo constante no direito processual e não há, na espécie, nada que possa ser considerado estranho à pratica nacional. (...) esta em jogo, na aplicação desta multa (...) a seriedade da Jurisdição e a própria autoridade do Estado; não se pode confundir esta situação com o inadimplemento de obrigação particular”. E conclui: “(...) Implica ela notável prestigio à autoridade da decisão judicial e a extirpação do seio da relação processual grave caso de má-fé e de ato protelatório, que tanto vêm preocupando a ciência processual e a população brasileira. (...)",418.

${ }^{418}$ ARENHART, Sérgio Cruz. A nova postura do relator no julgamento dos recursos. Revista de Processo. n. 103, ano 26, p. 57. 


\section{CAPÍtUlO 8 - QUESTÕes POLÊMICAS RELACIONADAS ì APLICAÇÃO DO ARTIGO 557 DO CÓDIGO DE PROCESSO CIVIL}

\section{A possibilidade de aplicação do disposto no artigo $515 \$ 3^{\circ}$ do Código de Processo Civil}

Inicialmente, importante destacar que a palavra "tribunal" que consta da redação do $\S 3^{\circ}$ do art. 515 do Código de Processo Civil foi empregada com a intenção de abranger a todos os órgãos do tribunal, não se referindo apenas ao "órgão colegiado" em si. Assim, a competência do relator para apreciar o mérito da causa não é, de forma alguma, afastada.

$\mathrm{O} \S 3^{\circ}$ do art. 515 do Código de Processo Civil estabelece expressamente os requisitos que permitem o julgamento imediato do mérito da causa, nos casos de extinção do processo sem julgamento do mérito, quais sejam: (i) a lide deverá versar sobre matéria exclusivamente de direito; e (ii) a causa deverá apresentar condições de imediato julgamento.

Em outros termos, referido dispositivo permite-nos concluir que o tribunal poderá julgar desde logo o mérito da causa, desde que essas condições sejam verificadas. O mérito da causa é inteiramente transferido ao tribunal, ainda que o pedido não tenha sido expressamente formulado.

A questão central é definir se o relator, ao afastar a carência da ação, dando provimento à apelação unipessoalmente com base no $§ 1^{\circ}$-A do artigo 557 do Código de processo Civil, poderá também iniciar o exame do mérito da causa com base no artigo 515, $\S 3^{\circ}$ do Código, com a intenção de acolher ou rejeitar o pedido sem que o órgão colegiado participe.

Uma interpretação literal do dispositivo mencionado acima em conjunto ao disposto no $\S 3^{\circ}$ do art. 515 do Código de Processo Civil, poderia levar à conclusão de que as regras são colidentes: de um lado, é atribuída competência ao tribunal para julgar o mérito da causa; de outro, ao relator, atribui-se a competência para julgar o mérito do recurso. 
Nesse sentido, se a decisão que extinguiu o processo sem julgamento do mérito sentença terminativa - estiver em contradição ao disposto em súmula ou jurisprudência dos tribunais de superposição, e desde que a causa atenda aos requisitos previstos no $\S 3^{\circ}$ do art. 515 do Código de Processo Civil, o relator poderá dar provimento ao recurso de apelação e também apreciar o mérito da causa ${ }^{419}$.

Sobre o assunto, Wanessa Françolin aponta que não há na lei qualquer impedimento à apreciação do recurso pelo relator, julgando desde logo a lide: "trata-se de recurso, e como tal, sujeita-se às regras expressas no art. 557 do $C P C^{, 420}$.

José Miguel Garcia Medina posiciona-se também no mesmo sentido: "o fato de não se estar diante de inconstitucionalidade, contudo, não torna, só por isso, menos criticável o preceito, porquanto nos casos em que, em atenção ao $\$ 3^{\circ}$ do art. 515 do Código de Processo Civil, o tribunal - ou o relator, sozinho (cf. Art. 557 do CPC) - julga questão de mérito que não havia sequer sido examinada pelo juízo a quo, estará realizando julgamento que só excepcionalmente poderá vir a ser reapreciado. "421.

Não poderá o relator, no entanto, afastar a extinção do processo sem julgamento do mérito, dando provimento à apelação e, ato contínuo, submeter a causa ao órgão colegiado.

\section{O julgamento do agravo retido}

Nos termos do art. 523, caput, do Código de Processo Civil, "na modalidade de agravo retido, o agravante requererá que o tribunal dele conheça, preliminarmente, por ocasião do julgamento da apelação".

Ainda que o agravo retido deva ser analisado previamente, antes de seu julgamento, deverão ser examinados os requisitos de admissibilidade da apelação, de modo que, caso a apelação não seja conhecida, da mesma forma o agravo retido também não o será.

\footnotetext{
${ }^{419}$ CARVALHO, Fabiano. Op cit. P. 239.

${ }^{420}$ FRANÇOLIN, Wanessa. Op cit., p. 21.

${ }^{421}$ Apud CARVALHO, Fabiano, p. 239.
} 


\section{Consequentemente, caso o relator entenda que a apelação é manifestamente}

inadmissível ou prejudicada, o que representa a perda superveniente do interesse recursal, não será apreciado o agravo retido em razão do vínculo de subordinação ${ }^{422}$.

${ }^{422}$ Nesse sentido: PROCESSUAL CIVIL. ADMINISTRATIVO. ACIDENTE OCORRIDO EM PRAÇA. BRINQUEDO SEM MANUTENÇÃO. QUEDA. LESÕES. DEVER DE INDENIZAR. DIVERGÊNCIA JURISPRUDENCIAL. REEXAME DO CONTEXTO FÁTICO-PROBATÓRIO. HONORÁRIOS. SÚMULA 7/STJ. JUROS. TEMPUS REGIT ACTUM. 1. A aplicação do artigo 557 do CPC pelo Relator equivale ao não conhecimento do recurso, o que implica na inadmissão do agravo retido e do apelo adesivo que lhes são acessórios. 2. Inexiste ofensa ao art. 535 do CPC, quando o tribunal de origem pronuncia-se de forma clara e suficiente sobre a questão posta nos autos. Ademais, o magistrado não está obrigado a rebater, um a um, os argumentos trazidos pela parte, desde que os fundamentos utilizados tenham sido suficientes para embasar a decisão. 3. A multa imposta com base no art. 538, parágrafo único, do CPC, deve ser excluída quanto atenta contra a ratio essendi da Súmula 98 do STJ. 4. A análise da existência de excludente da culpa estatal e o necessário nexo causal entre a suposta conduta omissiva e os prejuízos decorrentes da mesma implica em análise fático-probatória, razão pela qual descabe a esta Corte Superior referida apreciação em sede de recurso especial, porquanto é-lhe vedado atuar como Tribunal de Apelação reiterada ou Terceira Instância revisora, ante a ratio essendi da Súmula n. ${ }^{\circ}$ 07/STJ, verbis: "A pretensão de simples reexame de prova não enseja Recurso Especial" 5. Precedentes: AgRg no REsp 723893/RS DJ 28.11.2005; AgRg no Ag 556897/RS DJ 09.05.2005; REsp 351764/RJ DJ 28.10.2002. 6. In casu, assentou o Tribunal a quo, verbis:"(...) "(...) Quanto à alegação de inexistência de relação de causa e efeito entre a sua atuação administrativa e o evento descrito na inicial, o apelante também não tem razão, porque, como mostrou a sentença, a obrigação legal de manutenção era do Município apelante e por isso o fato dele criar uma Fundação em cumprir a sua finalidade criatória: já que ele sustenta que a personalidade jurídica da Fundação é diversa da sua, em tese tem ele direito de regresso contra ela pelo que pagar aqui, mas perante a vítima do acidente a obrigação indenizatória é do Município, dono da praça, da quadra de esportes e do aparelho que lesionou a vítima! (...) Quanto à alegação de que a indenização por danos materiais extrapolou dos $R \$ 41,00$ comprovados para $R \$ 150,00$ não comprovados, vale aqui repetir o argumento exposto linhas acima: o pagamento da pequeníssima quantia ( $\mathrm{R} \$ 150,00$, metade de um salário mínimo) encerra a discussão (pois o autor não recorreu dessa parte da sentença) sem nenhum prejuízo para o Erário (que aqui ou em outra ação teria que pagar mesmo a quantia). Não se pode abstrair, além disso, que o menor, com a perna engessada, ficou mesmo sem condições de se locomover por seus próprios meios, e pela idade que tinha seria bastante difícil deslocar-se com ele de ônibus (pois isso implicaria em alguém embarcar e desembarcar com ele no colo, arriscando-se a uma queda e a novas lesões), de forma que não há razão para modificar o entendimento do Dr. Juiz de $1^{\circ}$ Grau nesse particular (...)" (fls. 197/198) 7. Os juros, que deverão ser calculados, a partir do evento danoso (Súmula 54/STJ) à base de 0,5\% ao mês, ex vi artigo 1.062 do Código Civil de 1916 até a entrada em vigor do Novo Código Civil (Lei $\mathrm{n}^{\circ}$ 10.406/2001), nos termos previstos no seu art. 406. 8. A revisão do critério adotado pela Corte de origem, por eqüidade, para a fixação dos honorários, encontra óbice na Súmula 07 do STJ. No mesmo sentido, o entendimento sumulado do Pretório Excelso: "Salvo limite legal, a fixação de honorários de advogado, em complemento da condenação, depende das circunstâncias da causa, não dando lugar a recurso extraordinário." (Súmula 389/STF). Precedentes da Corte: REsp n. ${ }^{\circ}$ 779.524/DF, Rel. Min. Francisco Peçanha Martins, DJU de 06/04/2006; REsp 726.442/RJ, Rel. Min. Teori Albino Zavascki, DJU de 06/03/2006; AgRg nos EDcl no REsp 724.092/PR, , Rel. Min.Denise Arruda, DJU de 01/02/2006). 9. Por ofensa a direito local não cabe recurso extraordinário (Súmula 280/STF)10. A reapreciação da matéria constante da Lei Orgânica (art. 30, XIX) que daria supedâneo para a responsabilização do ente público implicaria em adentrar-se a questão de direito local, o que não se coaduna com os limites do recurso, incabível para rediscussão desta matéria. 11. A título de argumento obiter dictum "a obrigação de conservação de parques e jardins - e, a título de argumento em especial, dos equipamentos urbanos aos mesmos adicionados pelo próprio ente público - é encargo específico que grava o Município do Rio de Janeiro. O ente público, inclusive - também isto é enfatizado pela decisão relatorial -, mantém uma fundação com o encargo definido de velar pela conservação de parques e jardins públicos, gerando nos cidadãos a justa expectativa de que podem confiar a manutenção das facilidades colocadas à sua disposição. 12. In casu, apenas por argumentação, a responsabilidade estatal resta inequívoca, à luz do art. $37 \S 6^{\circ}$ da CF/1988, na hipótese vertente de ação ordinária de reparação de danos causados em acidente ocorrido em 
Por outro lado, caso o julgamento do agravo retido impossibilite o posterior julgamento da apelação (v.g. agravo retido interposto contra decisão que indeferiu a produção de alguma prova e entenda-se pela anulação da sentença), entendemos ser permitido ao relator julgar unipessoalmente o recurso se o julgamento do agravo retido for autorizado pelo artigo 557 do Código.

Mas e se o resultado do julgamento do agravo retido não for óbice ao posterior julgamento da apelação, pode o relator analisar unipessoalmente o agravo retido ao julgar monocraticamente a apelação?

Entendemos que o relator não pode cindir o julgamento. Assim, nessa hipótese, tanto o julgamento do agravo retido quanto o julgamento da apelação devem encontrar respaldo no artigo 557 do Código para que possam ser julgadas monocraticamente pelo relator.

Por outro lado, se a solução do agravo retido não criar óbice à apreciação da apelação, e na hipótese de essa apelação não comportar julgamento unipessoal, não será permitido ao relator julgar unipessoalmente o agravo retido. Seguindo a mesma linha de raciocínio, o relator não poderá julgar o agravo retido individualmente, ainda que o recurso seja manifestamente inadmissível ou prejudicado, se a apelação não comportar julgamento monocrático, seja de admissibilidade ou de mérito.

\section{Cabimento dos embargos de declaração}

Baseados no disposto no art. 537 do Código de Processo Civil, alguns doutrinadores sustentam não ser aplicável a regra do art. 557 aos embargos de declaração ${ }^{423}$.

praça, em desfavor da municipalidade, fundada na sua negligência que ocasionou danos materiais e morais à vítima (menor) lesionada quando brincava em brinquedo sem a manutenção devida. 13. Recurso especial parcialmente conhecido, e nesta parte parcialmente provido, apenas para excluir a multa do artigo 538 parágrafo único do CPC. (REsp 967491 / RJ, PRIMEIRA TURMA, Ministro LUIZ FUX, j.11/11/2008).

${ }^{423}$ CARVALHO, Fabiano. Op cit. P. 256. 
O entendimento do Superior Tribunal de Justiça, no entanto, é diametralmente oposto, no sentido de que a regra do art. 557 do Código de Processo Civil é aplicável aos embargos de declaração quando estes tratarem de matéria já pacificada no tribunal.

Nestes julgados considerou-se que como o artigo 557 do Código não especifica a quais recursos se aplica e que a regra nele inserida é posterior e especial em comparação à do artigo 537 do Código de Processo Civil, é possível o relator negar seguimento, monocraticamente, a embargos de declaração.

E mais. Como lembra Fabiano Carvalho ${ }^{424}$, é da competência exclusiva do relator sanar eventuais questões de omissão, contradição ou obscuridade do seu julgado. Dessa forma, seria evidentemente incoerente admitir que um integrante do órgão colegiado, que não seja o relator, pudesse alterar decisão da qual efetivamente não tomou parte. O autor ressalta ainda que, na hipótese de embargos de declaração interpostos contra acórdão, estes poderão ser apreciados pelo relator unipessoalmente, sem levá-los a conhecimento do órgão colegiado, quando for constatada a falta de um dos requisitos de admissibilidade, ou seja, quando o recurso for interpretado como manifestamente inadmissível ou prejudicado ${ }^{425}$.

Acerca do assunto, o art. 263, $\S 2^{\circ}$, do RISTJ, prevê que: "se os embargos forem manifestamente incabíveis, o relator a eles negara seguimento".

\section{Cabimento dos embargos infringentes e de divergência}

Segundo o disposto no art. 531 do Código de Processo Civil, "interpostos os embargos, abrir-se-á vista ao recorrido para contrarrazões; após, o relator do acórdão embargado apreciará a admissibilidade do recurso".

\footnotetext{
${ }^{424}$ Op. Cit., p. 257

${ }^{425}$ Por outro lado, a solução proposta não poderia ser a mesma para o caso de julgamento de mérito dos embargos de declaração, quando interpostos contra decisão colegiada. Nessa hipótese, não poderia o relator julgar unipessoalmente o mérito desse recurso.
} 
Como se vê da redação do artigo, cabe ao relator do acórdão embargado, em decisão monocrática, inadmitir os embargos infringentes que não satisfaçam os requisitos de admissibilidade. Bem se vê, portanto, que o relator do acórdão embargado não poderá apreciar o mérito do recurso em decisão monocrática, para dar ou negar provimento; o artigo 531 do Código de Processo Civil estabeleceu limite para sua atividade cognitiva, autorizando sua atuação singular apenas no que toca à apreciação das condições de admissibilidade dos embargos infringentes.

O Ministro do Superior Tribunal de Justiça, Ari Pargendler, no Resp. 152.930/MG, DJU de 15-12-1997, declarou que: “(...) o juízo de admissibilidade dos embargos infringentes é de exclusiva alçada do relator do acórdao embargado; depois de admitidos, os embargos infringentes devem ser levados a julgamento perante o órgão próprio, sem que o relator sorteado possa lhes negar seguimento em decisão individual.”. Conclui que: "Os embargos infringentes têm, no entanto, regra própria, especial, que atribui ao relator do acordao embargado apreciar a admissibilidade do recurso (CPC, art. 531), cabendo agravo para o órgão competente para o julgamento do recurso (CPC, art. 532). Admitidos os embargos, procederse-a ao sorteio do novo relator (CPC, art. 533, caput). O juízo de admissibilidade dos embargos infringentes, nesse contexto, é da alçada exclusiva do relator do acordao embargado; o relator sorteado para o julgamento dos embargos infringentes so recebe os autos depois de decorrido o prazo para a impugnação, tal como determina o artigo 534 do Codigo de Processo Civil”.

No REsp 506.873-RJ, O Ministro Cesar Asfor Rocha, manifestou o entendimento de que: “(...) o Relator, ao constatar manifesta inadmissibilidade ou improcedência, pode negar seguimento aos embargos infringentes, socorrendo-se do disposto no art. 557 do CPC. In casu, a negativa se deu em razão de os infringentes se apoiarem unicamente em voto vencido que nao admitiu o julgamento monocrático de embargos de declaração"426.

Destaca-se que o juízo de admissibilidade definitivo cabe sempre ao órgão ao qual foi atribuída competência para o julgamento do recurso. É da competência do relator do acórdão

\footnotetext{
${ }^{426}$ Informativo no 190 do Superior Tribunal de Justiça.
} 
embargado verificar a admissibilidade no momento de interposição dos embargos infringentes, mas possui o tribunal, órgão competente para o julgamento do mencionado recurso, competência para reapreciar a sua admissibilidade. Nota-se, assim, que a decisão que admite os embargos infringentes não impede a repetição de novo juízo de admissibilidade, com o intuito de se verificar se as condições recursais foram preenchidas.

Pontes de Miranda ensinava que: "o relator do acórdão embargado teve apenas a função de dar o primeiro impulso, sem intervir no processo, a despeito de poder negar a admissão aos embargos infringentes, de que cabe o chamado 'agravinho' do art. 532. Diferentemente é a função do relator dos embargos infringentes do julgado. Esse, que é sorteado, recebe o processo e examina se o caso é de atender-se aos embargos infringentes do julgado. Se o é, o relator sorteado estuda-o para seu relatório e voto" ${ }^{427}$.

Fabiano Carvalho ${ }^{428}$, que analisou o tema, assevera que, na hipótese de o relator do acórdão embargado ter inadmitido o recurso, mas a decisão ter sido reformada pelo órgão competente, com determinação para o seu processamento, não poderá o novo relator (dos embargos infringentes) negar seguimento ao recurso pelo mesmo fundamento. Contudo, o novo relator poderá, em decisão monocrática, inadmitir o recurso pela ausência de outro requisito que não tenha sido apreciado ainda pelo órgão, cabendo dessa decisão um novo agravo.

E pode o novo relator aplicar o disposto no artigo 557 ao analisar o mérito dos embargos infringentes. Sérgio Bermudes ${ }^{429}$ parece aceitar a hipótese ao firmar que " $O$ art. 557, na redação do art. $2^{\circ}$ da Lei n. 9.139, de 30.11.95, é norma para o relator dos embargos infringentes (art. 534), e não para o relator do acórdão embargado".

No mesmo sentido parece ser o entendimento de Barbosa Moreira: “(...) nessa ordem de ideias, continuara a incumbir ao relator estudar os autos e depois devolvê-los à secretaria, com o relatório (art. 549 e seu paragrafo único), a menos que ele próprio negue seguimento

\footnotetext{
${ }^{427}$ Op. Cit., p. 300.

428428 Op. Cit., p. 251.

${ }^{429}$ Comentários ao Código de Processo Civil de Pontes de Miranda, t. VIII, p. 300.
} 
aos embargos, nos termos do art. 557, caput, ou lhes dê provimento, com base no art. 557, $\S 1^{\circ}$ A"

Mencione-se também a hipótese de interposição de embargos de divergência, Conforme disposto na lei, a decisão da turma que (i) em recurso especial, divergir do julgamento de outra turma, da seção ou do órgão especial; e (ii) em recurso extraordinário, divergir do julgamento de outra turma ou do plenário, é sujeita à interposição de embargos de divergência, disciplinados pelos regimentos internos do Superior Tribunal de Justiça e do Supremo Tribunal Federal.

Os embargos de divergência são interpostos com o objetivo de forçar a revisão dos julgados conflitantes entre os órgãos que compõem o Superior Tribunal de Justiça (turmas, seção, órgão especial) ou o Supremo Tribunal Federal (turmas e plenários), acerca de determinada matéria.

No caso do Superior Tribunal de Justiça, o relator sorteado tem a competência para indeferir os embargos de divergência, liminarmente, quando: (i) intempestivos; ou (ii) quando contrariem súmula do Tribunal; ou (iii) não se comprovar ou não se configurar a divergência jurisprudencial.

Já no Supremo Tribunal Federal, ainda que não haja regra expressa em seu regimento interno, Fabiano Carvalho ${ }^{431}$ defende que, por meio de interpretação sistemática, é conferido ao relator dos embargos de divergência semelhante poder-dever, mas ressalta que a atividade de decisão (unipessoal) do relator restringe-se ao juízo de admissibilidade, não tendo o relator competência para analisar seu mérito.

Importante questão a respeito do tema refere-se ao cabimento dos embargos de divergência contra decisão unipessoal do relator que julga recurso especial ou recurso extraordinário. Milton Luiz Pereira afirma que: “(...) “com o alinhamento das pontuações

\footnotetext{
${ }^{430}$ Comentários ao Código de Processo Civil, vol. V, p. 539.

${ }^{431}$ Op. Cit., 261.
} 
realçadas, afigura-se propicia a inclusão de decisão laborada pelo relator, ex lege, substituindo o colegiado (art. 557 e $\S 1^{\circ}$-A, CPC), como examinável na via dos embargos de divergência, ultimando-se o escopo do reexame, sem a desnaturação da finalidade do recurso, acertado que a correção do julgamento não se desvia de sua base de sustentação originaria. Pois a decisão desafiada tem assentamento em sumula ou na jurisprudência pacificada por órgão colegiado. Ultima ratio, constitui singular reafirmação de julgamento firmado por colegiado." ${ }^{432}$.

Sérgio Cruz Arenhart corrobora esse pensamento: “[...] de toda sorte - e seja qual for a orientação que se adote em relação à natureza do agravo que sucede a analise feita pelo relator, na forma dos arts. $545, \S 3^{\circ}$, e 557 -, sendo correta a essência que aqui se empresta à figura do julgamento liminar feito pelo relator (como mera delegação da atividade do órgão fracionário), não se pode fugir da conclusão de que contra esta mesma decisão seria cabível a insurreição pela via dos embargos de divergência"433.

\section{Repercussão geral}

O $\S 3^{\circ}$ do artigo 103 da Constituição Federal, incluído pela Emenda Constitucional $n^{\circ}$ 45/2004, prevê que: “(...) no recurso extraordinário o recorrente deverá demonstrar a repercussão geral das questões constitucionais discutidas no caso, nos termos da lei, a fim de que o Tribunal examine a admissão do recurso, somente podendo recusá-lo pela manifestação de dois terços dos seus membros".

O mencionado dispositivo foi regulamentado pelos artigos. 543-A e 543-B do Código de Processo Civil, ambos incluídos pela Lei n. 11.418/2006, e pela Emenda Regimental n. 21, que modificou a redação dos artigos $13, \mathrm{~V}, \mathrm{c}, 21, \S 1^{\circ}, 322,323,324,325,326,327,328$ e 329 , e revogou o disposto no $\$ 5^{\circ}$ do artigo 321 , todos do Regimento Interno do Supremo Tribunal Federal.

\footnotetext{
432 “Embargos de divergência contra decisão lavrada por relator”, RePro, 101, p. 83.

433 "A nova postura do relator no julgamento dos recursos", RePro, 103, p. 50.
} 
O legislador constitucional foi além e determinou que a ausência de repercussão geral de determinado tema que enseja o não conhecimento do recurso extraordinário pelo Supremo Tribunal Federal deve ser declarada por dois terços de seus membros. Desse modo, atualmente, o quórum exigido para considerar inadmissível o recurso extraordinário, com base na falta da repercussão geral, é de oito dos onze ministros.

Conclui-se, com isso, que não é permitido ao relator, com fulcro no art. 557, caput, do Código de Processo Civil, não conhecer do recurso extraordinário sob o fundamento de ausência de repercussão geral que ainda não tenha sido analisada por todos os membros da Corte.

No entanto, existindo decisão do Plenário da Corte a respeito da inexistência de repercussão geral de determinada matéria, o relator estará autorizado a inadmitir monocraticamente o recurso com base no $§ 5^{\circ}$ do artigo 543-A do Código de Processo Civil que dispõe: "Negada a existência da repercussão geral, a decisão valera para todos os recursos sobre matéria idêntica, que serão indeferidos liminarmente, salvo revisão da tese, tudo nos termos do Regimento Interno do Supremo Tribunal Federal”.

Lembremos também a hipótese de o recurso ser inadmitido por meio de deisão singular quando não trouxer preliminar formal e fundamentada sobre a repercussão geral da questão, consoante dispõe o artigo $327, \S 1^{\circ}$, do RISTF.

Portanto, caso o recorrente deixe de demonstrar a repercussão geral das questões constitucionais em preliminar de recurso extraordinário, o relator estará autorizado a não conhecer do recurso extraordinário.

\section{A possibilidade de aplicação do disposto no artigo 285-A do Código de Processo Civil}

Questiona-se se a previsão do artigo 285-A, incluído pela Lei nº 11.277/2006 ao Código de Processo Civil, seria aplicável não só ao órgão judicial de primeiro grau, mas também aos órgãos colegiado e individual do tribunal. 
O estudo coube, novamente, a Fabiano Carvalho ${ }^{434}$ que manifesta o entendimento de que, apesar de uma primeira impressão ser a de que o disposto no artigo 285-A do Código de Processo Civil seria destinado ao juiz de primeiro grau, a interpretação deve superar a literalidade da lei para ser efetiva. Conclui o autor que a aplicação do disposto no art. 285-A deverá contar com algumas particularidades para que seja possível o julgamento unipessoal de recurso: (i) a matéria deve ser unicamente de direito; e (ii) deve haver decisões prolatadas pelo órgão colegiado do qual o relator faça parte, confirmando a improcedência do pedido em outras causas "idênticas".

${ }^{434}$ Op. Cit. P. 265. 


\section{CONCLUSÃO}

É notório que o Poder Judiciário brasileiro enfrenta uma verdadeira crise de morosidade e da justiça ${ }^{435}$, em que a confiança nos provimentos jurisdicionais e sua legitimidade são cada vez mais atacadas pela sociedade.

Não são novos os debates acerca da excessiva morosidade e da necessidade de revisão do sistema jurídico-processual ${ }^{436}$, a fim de que sejam implementados técnicas e instrumentos adequados à obtenção de tutela jurisdicional efetiva ${ }^{437}$. Busca-se a criação de um processo novo $^{438}$, que represente um instrumento adequado ao atendimento dos direitos, dotado de aptidão para assegurar à parte vitoriosa, com um mínimo dispêndio de tempo e energia, um resultado que lhe permita o gozo daquilo que lhe é de direito segundo o ordenamento.

Sobressai, pois, como uma das questões que mais tem preocupado os pensadores do direito, a do acesso à justiça. Como diz Comoglio ${ }^{439}$ : "l'accesso alla giustizia significa (e non protebbe non significare) per qualsiasi individuo la incondizionata ed effettiva liberta di agire gli organi giurisdizionali, al fine di domandare (ed, a processo concluso, eventualmente ottenere) la tutela adeguata ed effettiva dei diritti o degli interessi sostanziali fatti valere".

E ligado ao acesso à justiça está o conceito da efetividade da tutela jurisdicional, que depende da observância, em especial, do escopo social do processo de pacificar com justiça e a necessidade de que essa pacificação seja obtida de forma célere ${ }^{440}$, em tempo razoável ${ }^{441} 442$.

\footnotetext{
${ }^{435}$ LINS, Rodrigo Martiniano Ayres. A relativização do princípio do duplo grau cognitivo no processo civil brasileiro como instrumento de efetividade da tutela jurisdicional. Revista Forense, Rio de Janeiro, v.102, n.385, maio/jun. 2006, p. 181.

${ }^{436}$ MACHADO, Denise Maria Weiss de Paula; LEAL JÚNIOR, João Carlos. Análise crítica do duplo grau de jurisdição sob o prisma do direito à razoável duração do processo. Revista de Processo, São Paulo, v.35, n.183, maio. 2010, p. 102.

437 MARCATO, Antônio Carlos. "Considerações sobre a tutela jurisdicional diferenciada", in http://www.mundojuridico.adv.br/sis_artigos/artigos.asp?codigo=249, acessado em 30.3.2010

${ }^{438}$ DINAMARCO, Cândido Rangel. Nova Era do Processo Civil. $3^{\text {a }}$ ed. São Paulo: Malheiros, 2009, p.12.

${ }^{439}$ COMOGLIO, Luigi Paolo. Accesso alle corti e garanzie costituzionali. In YARSHELL, Flávio L.; ZANOIDE DE MORAES, Mauricio (coord.) Estudos em homenagem à Professora Ada Pellegrini Grinover. São Paulo: DPJ Editora, 2005, p. 277.

${ }^{440}$ Lembramos que a celeridade processual foi elevada à categoria de garantia constitucional com o advento da EC 45/2004, que incluiu o inc. LXXVIII ao art. $5^{\circ}$ da Constituição Federal.
} 
Mas, como definir o que seria razoável? Para Wambier, "será aquela (duração) em que melhor se puder encontrar o meio termo entre a definição segura da existência do direito e realização rápida do direito cuja existência foi reconhecida pelo juiz",443.

Como alertaram Cappelletti e Garth, “a Justiça que não cumpre suas funções dentro de um 'prazo razoável' é, para muitas pessoas, uma Justiça inacessível” ${ }^{444}$, de modo que a demora pode representar a denegação da própria justiça. Pior que isso, lembra Antonio Carlos Marcato $^{445}$, a conjugação desses fatores tende a afastar do Judiciário uma expressiva parcela do grupo social, circunstância que gera, na expressão de Kazuo Watanabe, a situação de "litigiosidade contida".

O processo passou a ser visto, pois, como instrumento cujos objetivos devem ser cumpridos sob pena de tornar-se socialmente ilegítimo e inútil. Como afirma Dinamarco, “o processo civil moderno quer ser um processo de resultados" 446 .

Não se quer, no entanto, dizer que a rapidez deve estar acima de tudo. Barbosa Moreira $^{447}$ tece oportunas críticas à crença de que "quanto mais depressa melhor", lembrando

\footnotetext{
${ }^{441}$ MARCATO, Ana Cândida Menezes. O Princípio do Duplo Grau de Jurisdição e a Reforma do CPC. São Paulo: Ed. Atlas, 2006, p. 39.

${ }^{442}$ Nesse sentido, José Rogério Cruz e Tucci afirma que: "Não deve apenas outorgar uma satisfação jurídica às partes, como também, para que essa resposta seja a mais plena possível, a decisão final deve ser pronunciada em um lapso de tempo compatível com a natureza do objeto litigioso, visto que - caso contrário - se tornaria utópica a tutela jurisdicional de qualquer direito. Como já se afirmou, com muita razão, para que a justiça seja injusta não faz falta que contenha equívocos, basta que não julgue quando deve julgar".

Prossegue o autor: "Não se pode olvidar, nesse particular, a existência de dois postulados que, em principio, são opostos: o da segurança jurídica, exigindo, como já salientado, um lapso temporal razoável para a tramitação do processo ("tempo fisiológico"), e o da efetividade deste, reclamando que o momento da decisão final não se procrastine mais do que o necessário ("tempo patológico"). Obtendo-se o equilíbrio desses dois regramentos segurança/celeridade -, emergirão as melhores condições para garantir a justiça no caso concreto, sem que, assim haja diminuição no grau de efetividade da tutela jurisdicional". (CRUZ E TUCCI, José Rogério. Garantia do processo sem dilações indevidas. Revista Jurídica, $\mathrm{n}^{\circ} 277$, nov. 2000).

${ }^{443}$ WAMBIER, Luiz Rodrigues; ARRUDA ALVIM WAMBIER, Teresa; MEDINA, José Miguel Garcia. Breves comentários à nova sistemática processual civil: Emenda Constitucional n. 45/2004 (reforma do Judiciário); Lei 10.444/2002; Lei 10.358/2001 e Lei 10.352/2001. 3. ed. Rev. Atual. E ampli. São Paulo: Ed. RT, 2005, p. 29/-30.

${ }^{444}$ MARCATO, Antonio Carlos. Op. Cit.

${ }^{445}$ Idem

${ }^{446}$ DINAMARCO, Cândido Rangel. A Reforma do Código de Processo Civil. São Paulo: Malheiros, 1996, p. 20.

447 BARBOSA MOREIRA, José Carlos, O futuro da justiça: alguns mitos. Revista da Associação dos Magistrados Brasileiros - Cidadania e Justiça, v. 4, nº 8, , jan/jun 2000, p. 7/10.
} 
que (i) a questão da morosidade não é fenômeno exclusivamente brasileiro; (ii) muitas vezes os jurisdicionados não clamam pela solução rápida dos litígios, pelo contrário, desejam que o feito se prolongue tanto quanto possível; (iii) a maior responsabilidade pela duração excessiva dos pleitos não decorre da legislação processual; e (iv) a lentidão não se sobrepõe a todos os demais problemas da Justiça.

É necessário, portanto, alcançar-se o equilíbrio entre certeza e razoável duração do processo para se chegar ao acesso à ordem jurídica adequadamente tempestiva. No quesito certeza, sobressai a importância do duplo grau de jurisdição na medida em que, em tese, tanto mais justa e acertada será a decisão quanto mais ela for examinada. Por outro lado, é necessário que o processo seja breve e que a decisão definitiva seja proferida sem procrastinações inúteis e no menor tempo possível ${ }^{448}$, não podendo ser permitido que os litígios se perpetuem indefinidamente no tempo, sob o pretexto de conferir maior segurança à parte que esta em juízo buscando o atendimento de sua pretensão ${ }^{449}$.

Bem se vê que o princípio do duplo grau de jurisdição, e portando, o sistema recursal, encontra-se em meio a esses dois fatores. Embora sua observância possibilite a consecução de uma tutela mais adequada e justa, o duplo grau de jurisdição e os recursos são tidos, por muitos, como verdadeiros óbices à busca da celeridade. Isso porque a enorme quantidade de recursos existente somada às numerosas possibilidades de interposição (e a sua interposição, muitas vezes, com fins meramente protelatórios ${ }^{450}$ ) posterga em muito a duração do processo, além de contribuir para a sobrecarga dos Tribunais e agravar a lentidão existente no tramite processual.

Assim, a segurança proclamada como fundamento do reexame redunda na instabilidade da ordem jurídica posta, na medida em que a decisão prolatada em $2^{\mathrm{a}}$ instância acaba se tornando censurável por ser intempestiva. Quanto maior for a duração do processo,

\footnotetext{
${ }^{448}$ GRINOVER, Ada Pellegrini. Um enfoque constitucional da teoria geral dos recursos. Revista Jurídica, Porto Alegre, v.42, n.198, abr. 1994, p. 39.

${ }_{449}$ MARCATO, Ana C. Menezes. Op. Cit., p. 40.

450 ROCCO, Ugo apud MARQUES, José Frederico. Instituições de Direito processual civil. Campinas: Millenium, 1999: "per cuia gli organi giurisdizionali, com poteri e limiti, specificamente determinati dal diritto processuali obiettivo, possono riesaminare il prodotto dell'attività degli organi giurisdizionale"
} 
mais ele se presta a prejudicar o autor que tem razão e a premiar o réu que não a tem ${ }^{451}$. Um processo que se estende por anos gera insegurança e desprestigia o sistema legal.

Neste sentido, a importância do estudo da ampliação dos poderes dos relatores. O desmedido aumento do número de recursos sem o correspondente aumento no quantitativo de magistrados, aliado à técnica de julgamento colegiado, resulta em enorme sobrecarga dos tribunais e em expressiva lentidão no desenvolvimento de suas atividades ${ }^{452}$. Como afirma Maria Berenice Dias, "a consagração do princípio do duplo grau de jurisdição não pode continuar a subjugá-lo à tradição de que todos os recursos merecem julgamento por órgãos coletivos" ${ }^{\text {} 453}$.

O prestígio ao julgamento monocrático possibilita a rápida solução dos litígios. Isso porque os recursos cujas teses jurídicas já foram reiteradamente decididas pelas cortes são apreciados rapidamente, sem que a questão objeto da irresignação tenha de ser submetida ao moroso rito tradicional (com apreciação pelo relator, revisão e julgamento ${ }^{454}$, além dos procedimentos de cunho administrativo $)^{455}$.

E a abreviação do procedimento em grau de revisão atinge também os recursos cujas teses jurídicas são mais complexas: como o número de recursos a serem julgados em sessão fica reduzido, também os recursos que versam sobre questões ainda não solucionadas pelos tribunais são apreciados em tempo menor ${ }^{456}$. Some-se a isso, ainda, a valorização dos

${ }^{451}$ LINS, Rodrigo Martiniano Ayres. Op. Cit., p. 181/182.

${ }^{452}$ VIVEIROS, Estefânia. Agravo interno no Superior Tribunal de Justiça e ampliação dos poderes do relator. Universitas/Jus, Brasília, n.7, jul./dez. 2001, p. 62.

453 DIAS, Maria Berenice. As decisões monocráticas do art. 557 do CPC. Disponivel em http://www.mariaberenice.com.br/uploads/4___as_decis\%F5es_monocr\%E1ticas_do_art._557_do_cpc_-_si.pdf. Acesso em 13.6.2012.

${ }^{454}$ Especialmente no que toca à dispensa da submissão das teses já resolvidas ao colegiado, sobre as quais a Câmara não controverte, Athos Gusmão Carneiro observou que "a ampliação dos poderes do relator parte inclusive de uma constatação pratica: na grande maioria das vezes, o voto do relator revela-se como o condutor do colegiado, em solução de consenso; assim, de todo razoável confiar desde logo o julgamento do recurso apenas ao relator, quando as circunstancias da causa a este permitam uma "certeza serena" sobre qual a justa composição da lide, ou quando se dispuser a julgar consoante a jurisprudência firme de seus pares ou de tribunal superior. Quando menos no Superior Tribunal de Justiça, a inovação esta cumprindo seu alto proposito". (Op. cit., p. 32)

${ }^{455}$ ARENHART, Sérgio Cruz. A nova postura do relator no julgamento dos recursos. Revista de Processo, São Paulo: Revista dos Tribunais, vol. 103, jul./set./2001, p. 37.

${ }^{456}$ CARNEIRO, Athos Gusmão. Op. cit., p. 10/11. 
precedentes judiciais e o consequente aumento do grau de segurança jurídica daquele que ingressa em juízo, por poder antecipar qual será o resultado final alcançado com o processo.

Bem se vê que as normas ampliativas dos poderes do relator não apenas pretendem mitigar o gravíssimo problema do acúmulo de recursos, como decorrem de uma renovada visão do processo voltada à necessidade de “operacionalizar o sistema, desburocratizá-lo, ou deformalizá-lo tanto quanto possível, com vista a facilitar a obtenção dos resultados justos que dele é lícito esperar" ${ }^{457}$. A crescente opção pelo julgamento singular, ampliando os poderes do relator, representa uma legítima tentativa de inovar sistematicamente na luta contra a lentidão do julgamento nos tribunais e de viabilizar uma Justiça capaz de oferecer solução para os $\operatorname{conflitos}^{458}$ através de um processo coexistencial e deformalizado, conduzido com a preocupação pelas necessidades do jurisdicionado, para que o acesso ao Poder Judiciário não seja apenas uma promessa formal, mas, sim, uma realidade ${ }^{459} 460$.

Deste modo, acredita-se que um estudo aprofundado do tema possa contribuir para o aprimoramento do regime jurídico pátrio de julgamento de recursos, no sentido de melhorar a técnica e a substância do direito processual, imprimindo notável dinamismo ao processo e acentuando seu caráter instrumental, para se viabilizar o acesso à tão proclamada ordem jurídica justa $^{461}$.

Tal análise, a nosso ver, permitiria aferir de uma forma mais nítida se a atual tutela jurídica dispensada à matéria presta-se a prover o amparo legal necessário e adequado para

\footnotetext{
${ }^{457}$ DINAMARCO, Cândido Rangel. A Reforma do Código de Processo Civil. São Paulo: Malheiros, 1996, p. 20. ${ }^{458}$ DINAMARCO, Cândido Rangel. Nova Era...Op. cit., p. 12.

${ }^{459}$ MARCATO, Ana C. Menezes. Op. Cit., p. 133

${ }^{460}$ Nesse contexto, conclui Maria Berenice Dias que "O alargamento particularmente atual e notável dos poderes do relator impõe-lhe uma verdadeira triagem dos recursos endereçados ao julgamento conjunto. Essa possibilidade veio com a salutar função de desobstruir a Justiça, ensejar a possibilidade de decisões mais céleres e propiciar, a par da resposta muito mais eficiente, a significativa redução de tempo, com acentuada repercussão econômica. Necessário se considere, além do dispêndio de tempo, o custo de toda a tramitação do recurso, quando possível, desejável e recomendável seja ele apreciado imediatamente" (Op. cit.).

${ }^{461}$ É sempre importante lembrar, nas oportunas conclusões de Kazuo Watanabe que o direito de acesso à justiça possui como dados elementares: (i) direito à informação e perfeito conhecimento do direito substancial; (ii) direito de acesso à Justiça adequadamente organizada e formada por juízes inseridos na realidade social e comprometidos com o objetivo de realização da ordem jurídica justa; (iii) direito a instrumentos processuais capazes de promover a efetiva tutela de direitos; e (iv) direito à remoção de todos os obstáculos que se anteponham ao acesso efetivo à Justiça. (WATANABE, Kazuo. Acesso à justiça e sociedade moderna. In GRINOVER, Ada Pellegrini et. al. Participação e processo. São Paulo: RT, 1988, p. 128/135).
} 
que se proporcione, satisfatoriamente, a tão almejada efetividade. 


\section{BIBLIOGRAFIA}

ABDO, Helena Najjar. O abuso do processo. São Paulo: RT, 2007.

ALMEIDA, Marcelo Pereira de. O sistema recursal e o direito à tutela à luz do inc. LXXVIII, do art. $5^{\circ}$, da CF (E. C. n ${ }^{\circ}$ 45/2004). Revista da EMERJ, Rio de Janeiro, v.10, n.37, p.238-57, 2007.

ALVAREZ, Maria Auxiliadora Garcia Duran. Considerações sobre o parágrafo 3. do art. 515 do CPC. Revista Forense, Rio de Janeiro: Forense, vol. 381, p.135-149, set./out./2005.

ALVIM, Arruda. Cabimento de embargos de divergência contra acórdão (de mérito) de turma, proferido em agravo regimental, tirado de decisão de relator de recurso extraordinário imprescindibilidade de uma releitura da súmula no. 599/STF. Revista Forense, Rio de Janeiro, v.103, n.389, p.31-41, jan./fev. 2007.

. Manual de Direito Processual Civil: Processo de Conhecimento, v.

2. $9^{\mathrm{a}}$ ed., São Paulo: Editora Revista dos Tribunais, 2005.

ALVIM, Eduardo Arruda. Discussão sobre a nova redação do artigo 557, do CPC, dada pela Lei 9.756/98. In: ROCHA, Valdir de Oliveira (coord.). Problemas de processo judicial tributário. São Paulo, Dialética: 1999. p.83-94.

; ALVIM, Angélica Arruda. As Reformas e o Sistema Recursal. Revista Forense, v. 389, Jan/fev./ 2007.

ALVIM, José Eduardo Carreira. Agravo Retido e Agravo de Instrumento. Nova Mini-Reforma do Código de Processo Civil. Revista de Processo, v. 130, dez/2005. 
. Recurso per saltum: sugestão para a justiça do terceiro milênio.

Revista do Instituto dos Advogados de São Paulo, São Paulo, v.5, n.10, p.86-93, jul./dez. 2002.

AMARAL DOS SANTOS, Moacyr. Primeiras Linhas de Direito Processual Civil, vol. I. São Paulo: Editora Saraiva, 2004.

ANDRADE, Érico. O Regime do Recurso de Agravo e suas Alterações: do CPC de 1973 até a Lei n. 11.187/05. Repertório de Jurisprudência IOB, v. 3/21, 1ª quinzena nov/2006.

ARAÚJO CINTRA, Antonio Carlos; GRINOVER, Ada Pellegrini; DINAMARCO, Cândido Rangel. Teoria geral do processo. São Paulo: Malheiros, 2004.

ARAÚJO, Izaías Batista de. Do impedimento do Ministro Relator quando decide recurso com base no art. 38 da lei 8,038/90, Aplicação do art. 134, III do CPC. Revista dos Tribunais, Paulo, v.83, n.716, p.363-4, jun. 1995.

ARAÚJO, José Henrique Mouta. A eficácia da decisão envolvendo a repercussão geral e os novos poderes dos relatores e dos tribunais locais. Revista Autônoma de Processo, Curitiba, n.4, p.269-86, jul./set. 2007.

ARENHART, Sérgio Cruz. A nova postura do relator no julgamento dos recursos. Revista de Processo, São Paulo: Revista dos Tribunais, vol. 103, p.37-58, jul./set./2001.

ARMELIN, Donaldo. “Apontamentos sobre as alterações ao Codigo de Processo Civil e à Lei 8.038/90, impostas pela Lei 9.756/98". Aspectos polêmicos e atuais dos recursos cíveis de acordo com a Lei 9.756/98. Coord. Teresa Arruda Alvim Wambier e Nelson Nery Jr., Sao Paulo: RT, 1999. 
ARRIBAS, Bruno Felipe da Silva Martin de. Decisão monocrática relatorial: análise do artigo 557 do código de processo civil. Revista da Esmape, Recife, v.9, n.20, p.97-127, jul./dez. 2004.

ASSIS, Araken de. Formação do julgamento colegiado nos tribunais. Revista do Advogado, São Paulo, v.26, n.88, p.13-19, nov. 2006.

. Regime Vigente do Agravo Retido. Revista do Advogado, v. 85, mai/2006.

ATAIDE JR., VICENTE DE PAULA. As Novas Reformas do Processo Civil: Leis 11.187 e 11.232, de 2005; 11.276, 11.277 e 11.280, de 2006. Curitiba: Juruá Editora, 2006.

AULETTA, Ferruccio. Le specialità del processo civile davanti al giudice monocratico del tribunale. Rivista di Diritto Processuale, Padova, v.56, n.1, p.145-61, gen./mar. 2001.

BAPTISTA DA SILVA, Ovídio Araújo. Processo e Ideologia. Revista de Processo, São Paulo: Editora Revista dos Tribunais, ano 28, n. 110, abr/jun/ 2003.

BARBOSA MOREIRA, José Carlos. A duração dos processos: alguns dados comparativos. Revista da Ajuris, Porto Alegre, v.32, n.98, p.151-9, jun. 2005.

A Efetividade do Processo de Conhecimento. Revista de Processo, São Paulo: Editora Revista dos Tribunais, ano 19, n. 74, abril - junho de 1994.

Algumas Inovações da Lei 9.756 em Matéria de Recursos Civis. Revista Forense, v. 346, p. 93/100, abr/jun/1999. 
- As reformas do código de processo civil: condições de uma avaliação objetiva. Revista Forense, Rio de Janeiro, v.92, n.335, p.97-104, jul./set. 1996.

. Comentários ao Código de Processo Civil, Lei $n^{\circ} 5.869$, de 11 de janeiro de 1973: art. 476 a 565, vol. V. Rio de Janeiro: Editora Forense, 2008.

. Eles, os recursos, vistos por um advogado (reflexões em matéria de recursos cíveis). Revista Forense, Rio de Janeiro, v.98, n.360, p.341-9, mar./abr. 2002.

- Inovações da Lei 9.756 em matéria de recursos civis. In WAMBIER, Teresa Arruda Alvim; NERY JUNIOR, Nelson (coord.). Aspectos polêmicos $e$ atuais dos recursos cíveis de acordo com a Lei 9.756/98. São Paulo: Revista dos Tribunais, 1999.

. Julgamento colegiado e pluralidade de causas de pedir. Revista de Direito do Tribunal de Justiça do Estado do Rio de Janeiro, n.1, p.15-8, 1985.

. Notas sobre alguns fatores extrajurídicos no julgamento colegiado. Revista de Processo, São Paulo, v.19, n.75, p.7-25, jul./set. 1994.

- O futuro da justiça: alguns mitos. Revista da Associação dos Magistrados Brasileiros - Cidadania e Justiça, v. 4, nº 8, , jan/jun 2000.

. O Juiz e a cultura da transgressão. Revista Jurídica, Porto Alegre, v.47, n.267, p.5-12, jan. 2000.

- O problema da duração dos processos: premissas para uma discussão séria. Revista Magister de Direito Civil e Processual Civil, Porto Alegre, v.2, n.12, p.27-36, maio/jun. 2006. 
. O processo civil contemporâneo: um enfoque comparativo. Revista Brasileira de Direito Comparado, Rio de Janeiro, n.25, p.65-86, 2004.

- Por um processo socialmente efetivo. Revista de Processo, São Paulo, v.27, n.105, p.181-90, jan./mar. 2002.

- Questões de técnica de julgamento nos Tribunais. Revista de Direito do Tribunal de Justiça do Estado do Rio de Janeiro, Rio de Janeiro, n.59, p.13-25, abr./jun. 2004.

. Reformas do CPC em matéria de recursos. Revista da EMERJ, Rio de Janeiro, v.4, n.13, p.51-64, 2001.

- Reformas processuais e poderes do juiz. Revista de Direito do Tribunal de Justiça do Estado do Rio de Janeiro, Rio de Janeiro, n.56, p.13-25, jul./set. 2003. . Reformas Processuais. Revista Jurídica, Porto Alegre, v.47, n.258, p.5-9, abr. 1999.

. Restrições ilegítimas ao conhecimento dos recursos. Revista IOB de Direito Civil e Processual Civil, Porto Alegre, v.7, n.39, p.50-62, jan./fev. 2006.

. Súmula, jurisprudência, precedente: uma escalada e seus riscos. Revista Síntese de Direito Civil e Processual Civil, Porto Alegre, v.6, n.35, p.5-16, maio/jun. 2005.

BARIONI, Rodrigo Otavio. A proibição da reformatio in peius e o parágrafo $3^{\circ}$ do art. 515 do CPC. In: NERY JUNIOR, Nelson (coord.); WAMBIER, Teresa Arruda Alvim (coord.). Aspectos polêmicos e atuais dos recursos cíveis e de outros meios de impugnação às decisões judiciais. São Paulo: Revista dos Tribunais, 2005, p.693-722. 
BARROSO, Luís Roberto. A americanização do direito constitucional e seus paradoxos: teoria e jurisprudência constitucional no mundo contemporâneo. Interesse Público, Belo Horizonte, v.12, n.59, p.13-55, jan./fev. 2010.

. A atribuição de voto duplo a membro de órgão judicante colegiado e o devido processo legal. Revista do IBRAC, São Paulo, v.16, n.1, p.45-74, 2009.

BARRUFINI, Frederico Liserre. Possibilidade de efetivação do direito à razoável duração do processo. Revista de Estudos Jurídicos UNESP, Franca, v.11, n.15, p.99-119, 2006.

BEDAQUE, José Roberto dos Santos. Direito e Processo. $3^{\text {a }}$ Edição. São Paulo: Malheiros Editores, 2003.

- Efetividade do Processo e Técnica Processual. São Paulo: Malheiros Editores, 2006.

- Tutela Cautelar e Tutela Antecipada: Tutelas Sumárias e de Urgência: Tentativa de Sistematização. $2^{\text {a }}$ Edição. São Paulo: Malheiros Editores, 2001.

; CARMONA, Carlos Alberto. A posição do juiz: tendências atuais. Revista Forense, Rio de Janeiro, v.96, n.349, p.85-99, jan./mar. 2000.

BENJÓ, Bela. Considerações sobre a súmula da jurisprudência predominante. Revista de Direito do Tribunal de Justiça do Estado do Rio de Janeiro, Rio de Janeiro, n.53, p.386-8, out./dez. 2002.

BERMUDES, Sérgio. A Reforma do Código de Processo Civil. $2^{\text {a }}$ Edição. São Paulo: Editora Revista dos Tribunais, 1996. 
Comentários ao Código de Processo Civil. São Paulo: RT, 1975, vol. VII, n. 239.

BIDART, Adolfo Gelsi. Del tiempo procesal y su manejo. Revista de Processo, São Paulo, v.24, n.93, p.191-96, jan./mar. 1999.

BOTELHO DE MESQUITA, José Ignácio. A Crise do Judiciário e o Processo. Teses, Estudos e Pareceres de Processo Civil, Volume I, $1^{\text {a }}$ Edição, São Paulo: Editora Revista dos Tribunais, 2005.

As Novas Tendências do Direito Processual: Uma Contribuição para o seu Reexame. Teses, Estudos e Pareceres de Processo Civil, Volume I, $1^{\text {a }}$ Edição, São Paulo: Editora Revista dos Tribunais, 2005. . Uniformização de Jurisprudencia. LEX: Jurisprudencia do Supremo Tribunal Federal, São Paulo, v.19, n.226, p.5-9, out. 1997.

BOTTINI, Pierpaolo Cruz; RENAULT, Sérgio. Os Caminhos da Reforma. Revista do Advogado, v. 85, maio/2006.

BRASIL. Conselho Nacional de Justiça. Justiça em Números 2008: Variáveis e Indicadores do Poder Judiciário. Disponível em http://www.cnj.jus.br/images/imprensa/justica_em_numeros_2008.pdf, acesso em 11.10.10.

BRASIL. Presidência da República. Exposição de Motivos do Código de Processo Civil: Lei $n^{o}$ 5.869, de 11 de janeiro de 1973. Disponível em http://www.ombadvocacia.com.br/acervo/CODIGOS/CODIGOPROCESSOCIVIL.PDF?PHP $\underline{\mathrm{SESSID}=09 \mathrm{f} 6712 \mathrm{e} 2 \mathrm{bc} 1 \mathrm{a} 36 \mathrm{bac} 319854 \mathrm{~d} 3 \mathrm{da} 27 \mathrm{~b} 1}$, acesso em 11.10 .10 
BRUSCHI, Gilberto Gomes. A revisão da decisão monocrática do relator do agravo de instrumento com base nos incisos II e III do art. 527 do Código de Processo Civil. Revista Dialética de Direito Processual, São Paulo, n.86, p.48-56, maio. 2010.

. Existe recurso contra a decisão do relator com base no art. 527, III, do CPC?. Revista de Processo, São Paulo: Revista dos Tribunais, vol. 145, p.365-373, $\operatorname{mar} . / 2007$.

BUENO, Cássio Scapinella. Curso Sistematizado de Direito Processual Civil, v. 5. São Paulo: Saraiva, 2008.

- A Nova Etapa da Reforma do CPC: Comentários Sistemáticos às Leis n. 11.276, 11.277, de 7.2.2006 e 11.280, de 16.2.2006. São Paulo: Saraiva, 2009.

BUZAID, Alfredo. Da uniformização da jurisprudencia. Boletim da Faculdade de Direito da Universidade de Coimbra, n.58, p.127-67.

. Estudos de direito. São Paulo: Saraiva, 1972, vol. I.

CABRAL, Bernardo. A palavra do relator: ontem, há vinte anos. Revista de Informação Legislativa, Brasília, v.45, n.179, p.81-88, jul./set. 2008.

CADIET, Loic; GUINCHARD, Serge. Le double degre de juridiction. Justices: revue generale de droit processuel, Paris, n.4, p.1-8, juil./dec. 1996.

CALMON DE PASSOS, José Joaquim. Instrumentalidade do Processo e Devido Processo Legal. Revista Forense, Rio de Janeiro: Editora Forense, ano 96, n. 351, , jul./set/2000. 
. O Problema do Acesso à Justiça no Brasil. Revista de Processo, São Paulo: Editora Revista dos Tribunais, ano X, n. 39, , jul./set/1985.

CÂMARA, Alexandre Freitas. Bases Teóricas Para Um Novo Código de Processo Civil. Bases Científicas para um renovado Direito Processual, vol.1, IBDP, 2008.

CAMBI, Accácio. Atribuição inovadora concedida ao relator: negar seguimento ou dar provimento ao recurso monocraticamente. Artigo 557 do código de processo civil. Doutrina ADCOAS, São Paulo: Esplanada, vol. 6, p.166-169, jun./2001.

CAMBI, Eduardo. Mudando os rumos da apelação: comentários sobre a inclusão, pela lei 10.352/2001, do parágrafo 3 ao artigo 515 do CPC. In: NERY JUNIOR, Nelson (coord.); WAMBIER, Teresa Arruda Alvim (coord.). Aspectos polêmicos e atuais dos recursos e de outros meios de impugnação às decisões judiciais. São Paulo: Revista dos Tribunais, 2002. p.179-184.

CARBONE, Vincenzo. Giudice monocratico e giudice collegiale. Rivista di Diritto Processuale, Milano, v.51, n.2, p.552-73, apr./giug. 1996.

CARMONA, Carlos Alberto. "O sistema recursal brasileiro: breve analise critica". Aspectos polêmicos e atuais dos recursos. Coord. Eduardo Pellegrini de Arruda Alvim, Nelson Nery Jr. e Teresa Arruda Alvim Wambier. Sao Paulo: RT, 2000.

CARNEIRO JÚNIOR, Amílcar Araújo; WAMBIER, Luiz Rodrigues. Uma contribuição para o estudo da razoável duração do processo. Revista Jurídica, Sapucaia do Sul, v.58, n.396, p.11-45, out. 2010. 
CARNEIRO, Athos Gusmão. Inovações da Lei 9.756, de 17.12.1998, no Âmbito do Processo Civil. Revista de Processo, v. 93, jan/mar/1999.

. O Novo Recurso de Agravo e Outros Estudos. 4a ed. Rio de Janeiro:

Forense 1997.

. Poderes do relator e agravo interno: art. 557, 544 e 545 do CPC.

Revista de Processo, São Paulo, v.25, n.100, p.9-32, out./dez. 2000.

; TEIXEIRA, Sálvio de Figueiredo. A Reforma do Processo Civil Simplificação e Agilização, Revista da Escola Paulista de Magistratura, n. 0, ano 1, abrilmaio.

CARREIRA ALVIM, J.E. Ação monitoria e temas polêmicos da reforma processual. $3^{\mathrm{a}}$ ed. Belo Horizonte: Del Rey, 2001.

. Teoria Geral do Processo. $8^{\mathrm{a}}$ Edição. Rio de Janeiro: Editora

Forense, 2002.

CARVALHO, Fabiano. A função do relatório no julgamento colegiado. Manifestação do princípio do contraditório. Revista de Processo, São Paulo, v.36, n.198, p.445-54, ago. 2011.

- Ação rescisória contra decisão do relator. In: MEDINA, Jose Miguel Garcia (coord.); CRUZ, Luana Pedrosa de Figueiredo (coord.); CERQUEIRA, Luis Otavio Sequeira de (coord.); GOMES JUNIOR, Luiz Manoel (coord.). Os poderes do juiz e o controle das decisões judiciais: estudos em homenagem à Professora Teresa Arruda Alvim Wambier. São Paulo: Revista dos Tribunais, 2008. p.1013-1019. 
. Julgamento unipessoal do mérito da causa por meio da apelação: interpretação dos art. 557 e 515, parágrafo 3., ambos do CPC. Revista de Processo, São Paulo: Revista dos Tribunais, vol. 144, p.113-116, fev./2007.

. Poderes do relator nos recursos: art. 557 do CPC. São Paulo:

Saraiva, 2008.

CHIOVENDA, Giuseppe. Instituições de Direito Processual Civil. São Paulo: Editora Saraiva, 1965.

CIANCI, Mirna. A lei n. 9.756/1998 (CPC, artigos 544, par. 3 e 557, pars. 1 a 3) e a ampliação dos poderes do relator, dez anos depois. Revista Brasileira de Direito Processual, Belo Horizonte, v.16, n.61, p.103-19, jan/mar. 2008.

CLAUS, Ben-Hur Silveira; LORENZETTI, Ari Pedro; FIOREZE, Ricardo; ARAÚJO, Francisco Rossal de; COSTA, Ricardo Martins; AMARAL, Márcio Lima do. A função revisora dos tribunais - a questão do método no julgamento dos recursos de natureza ordinária. Revista Trabalhista: Direito e Processo. Brasília. v.9, n.35, p.22-39, out./dez. 2010.

COELHO, Marcus Vinicius Furtado. O Anteprojeto de Código do Processo Civil: a busca por celeridade e segurança. Revista de Processo, São Paulo, v.35, n.185, p.145-50, jul. 2010.

COMOGLIO, Luigi Paolo. Accesso alle corti e garanzie costituzionali. In YARSHELL, Flávio L.; ZANOIDE DE MORAES, Mauricio (coord.) Estudos em homenagem à Professora Ada Pellegrini Grinover. São Paulo: DPJ Editora, 2005.

. La durata ragionevole del processo e le forme alternative di tutela. Rivista di Diritto Processuale, Padova, v.62, n.3, p.591-619, magg./giug. 2007. 
; FERRI, Conrado; TARUFFO, Michele. Lezione sul processo civile.

Bologna: Il Mulino, 1995.

CORRÊA, José Machado. Recurso de Agravo História e Dogmática Por mais de 500 anos. São Paulo: Iglu, 2001.

COSTA, Hélio Rubens Batista Ribeiro. A inconstitucionalidade da primeira parte do paragrafo 3, do artigo 544 do Código de Processo Civil e demais questões referente ao julgamento monocratico dos recursos constitucionais. Revista do Instituto dos Advogados de São Paulo, São Paulo, v.2, n.4, p.113-22, jul./dez. 1999.

COUTURE, Eduardo J. Fundamentos del Derecho Procesal Civil. $3^{\mathrm{a}}$ ed., Buenos Aires: Ed. Depalma, 1985.

CRITSINELIS, Marco Falcão. A inconstitucionalidade do artigo 557 do código de processo civil. Doutrina ADCOAS, São Paulo, vol. 5., p.140-151, maio/1999.

CUNHA, Eurípedes Brito. Despacho/decisão do relator: natureza jurídica; possibilidade de desconstituição por via de ação rescisória. Revista Síntese de Direito Civil e Processual Civil, Porto Alegre, v.3, n.18, p.32-7, jul./ago. 2002.

CUNHA, Leonardo José Carneiro da. As Recentes Modificações no Agravo. Revista Dialética de Direito Processual, São Paulo, no 33, dez/2005.

. O principio da proibição da reformatio in pejus e o novo paragrafo 3 do artigo 515 do código de processo civil. Repertório de Jurisprudência IOB, São Paulo: Thomson/IOB, vol. 3/8, p.197, 2quinz./abr./2003. 
DALL'AGNOL JUNIOR, Antonio Janyr. Admissão do Recurso de Apelação e Súmulas: Exegese do Art. 518, Parágrafo 1º do CPC. Revista do Advogado, v. 85, mai/2006.

DALLARI, Dalmo de Abreu. O poder dos juízes. São Paulo: Saraiva, 1996.

DANTAS, Ana Carolina de Araújo. Embargos declaratórios: da possibilidade de interposição em face de decisão monocrático do relator proferida com fulcro no artigo 557 do CPC. IOB Repertório de Jurisprudência: Civil, Processual, Penal e Comercial, São Paulo, v.3, n.8, p.309-302, abr. 2011.

DANTAS, Bruno. A jurisprudência dos tribunais e o dever de velar por sua uniformização e estabilidade. Revista de Informação Legislativa. Brasília. v.48, n.190 t.1, p.61-73, abr./jun. 2011.

DIAS, Handel Martins. O tempo e o processo. Revista da AJURIS, Porto Alegre, v.34, n.108, p.227-45, dez. 2007.

DIAS, Maria Berenice. As decisões monocráticas do art. 557 do CPC. Disponivel em http://www.mariaberenice.com.br/uploads/4_-

_as_decis\%F5es_monocr\%E1ticas_do_art._557_do_cpc_-_si.pdf. Acesso em 13.6.2012.

As decisões monocráticas do artigo 557 do código de processo civil.

Doutrina ADCOAS, São Paulo: Esplanada, vol. 8, p.267-270, ago/2002.

DIAS, Ronaldo Bretas de Carvalho. Direito à jurisdição eficiente a garantia da razoável duração do processo na reforma do Judiciário. Revista de Processo, São Paulo, v.30, n. 128, p.164-74, out. 2005 .

DIDIER JR., Fredie. Curso de Direito Processual Civil: Teoria Geral do Processo e Processo de Conhecimento, v. 1. Salvador: JusPODIVM, 2006. 
; CUNHA, Leonardo José Carneiro da. Curso de Direito Processual Civil - Meios de Impugnação às decisões judiciais e Processo nos Tribunais. Salvador: JusPodivm, 2010.

; JORGE, Flávio Cheim; RODRIGUES, Marcelo Abelha. A Terceira Etapa da Reforma Processual Civil: Comentários às Leis n. 11.187 e 11.232, de 2005; 11.276, 11.277 e 11.280, de 2006. São Paulo: Editora Saraiva, 2006.

DINAMARCO, Cândido Rangel. A Instrumentalidade do Processo. 12a ed., São Paulo: Malheiros Editores, 2005.

- A instrumentalidade do processo. Revista da Fundação Escola Superior do Ministério Publico do Distrito Federal e Territórios, Brasília, v.2, n.4, p.25-41, jul./dez. 1994.

. A Reforma da Reforma. São Paulo: Malheiros, 2002.

. A Reforma do Código de Processo Civil. São Paulo: Malheiros, 1996.

. Decisões vinculantes. Revista de Processo, São Paulo, v.25, n.100, p.166-85, out./dez. 2000.

. Fundamentos do Direito Processual Civil Moderno. $3^{\mathrm{a}}$ ed., São Paulo: Malheiros Editores, 2000.

- Instituições de Direito Processual Civil. $4^{\mathrm{a}}$ ed., São Paulo: Malheiros Editores, 2004. 
. Nova Era do Processo Civil. $3^{a}$ ed., São Paulo: Malheiros, 2009.

- O relator, a jurisprudência e os recursos. In: WAMBIER, Teresa Arruda Alvim (coord.); NERY JUNIOR, Nelson (coord.). Aspectos polêmicos e atuais dos recursos cíveis de acordo com a lei 9.756/98. São Paulo: Revista dos Tribunais, 1999. p.127144.

. Sumulas vinculantes. Revista Forense, Rio de Janeiro, v.95, n.347, p.51-65, jul./set. 1999 .

. Superior Tribunal de Justiça e acesso a ordem jurídica justa. Revista de Processo, São Paulo, v.15, n.59, p.14-21, jul./set. 1991.

DINIZ, Jose Janguie Bezerra. Princípios constitucionais do processo. Trabalho e Doutrina: processo jurisprudencia, São Paulo, n.13, p.104-24, jun. 1997.

FABRÍCIO, Adroaldo Furtado. Extinção do Processo e Mérito da Causa, Revista de Processo, São Paulo: Editora Revista dos Tribunais, ano 15, n. 58, abr/jun/1990.

. Tutela antecipada: denegação no primeiro grau e concessão pelo relator do agravo. In: TEIXEIRA, Sálvio de Figueiredo (coord.). Estudos em homenagem ao Ministro Adhemar Ferreira Maciel. São Paulo, Saraiva, 2001, p.1-15.

FERNANDES, Sérgio Ricardo de Arruda. A influência da jurisprudência dos tribunais no julgamento realizado na instância revisora. Revista de Direito do Tribunal de Justiça do Estado do Rio de Janeiro, Rio de Janeiro, n.67, p.60-9, abr./maio. 2006.

FERREIRA FILHO, Manoel Caetano. O Indeferimento liminar do agravo de instrumento pelo relator. Revista de Processo, São Paulo, v.18, n.69, p.227-34, jan/mar. 1993. 
FERREIRA, William Santos. Decisões do relator e a recorribilidade assegurada pelo parágrafo único do art. 527 do CPC: uma questão de perspectiva. In: MEDINA, Jose Miguel Garcia (coord.); CRUZ, Luana Pedrosa de Figueiredo (coord.); CERQUEIRA, Luis Otavio Sequeira de (coord.); GOMES JUNIOR, Luiz Manoel (coord.). Os poderes do juiz e o controle das decisões judiciais: estudos em homenagem à Professora Teresa Arruda Alvim Wambier. São Paulo: Revista dos Tribunais, 2008. p.867-877.

FERRO, Marcelo Roberto. A jurisprudencia como forma de expressão do direito. Revista de Direito Civil, Imobiliário, Agrário e Empresarial, São Paulo, v.14, n.51, p.89-103, jan/mar. 1990.

FONSECA, Vicente José Malheiros da. O papel da Jurisprudência. Revista do Tribunal Regional do Trabalho da $8^{a}$ Região, Belém, v.37, n.73, p.25-36, jul./dez. 2004.

FRANÇOLIN, Wanessa de Cássia. A ampliação dos poderes do relator nos recursos cíveis. Rio de Janeiro: Editora Forense, 2006.

FRANZE, Luis Henrique Barbante. Breves considerações sobre a atual roupagem do artigo 557 do CPC. Revista do Instituto de Pesquisas e Estudos, Bauru, vol. 29, p.191-206, ago/nov/2000.

FREDERICO, Alencar. A Nova Reforma do Código de Processo Civil. $2^{\mathrm{a}}$ ed., Campinas: Editora Millennium, 2006.

FUX, Luiz. A Reforma do Processo Civil: Comentários e Análise Crítica da Reforma Infraconstitucional do Judiciário e da Reforma do CPC. Niterói: Editora Impetus, 2006.

- Curso de direito processual civil. Volume 1: Processo de Conhecimento. $3^{\mathrm{a}}$ ed., Rio de Janeiro: Forense, 2005. 
GAJARDONI, Fernando da Fonseca. Breve Análise Estatística de Alguns Pontos da Primeira Fase das Reformas Processuais Civis no Âmbito da Justiça Estadual Paulista, Revista da Escola Paulista da Magistratura, v. 5, nº 1, jan/jun/2004.

. O Princípio Constitucional da Tutela Jurisdicional sem Dilações Indevidas e o Julgamento Antecipadíssimo da Lide. Revista de Processo, São Paulo: Editora Revista dos Tribunais, ano 31, n. 141, nov/2006.

. Os Reflexos do Tempo no Direito Processual Civil (uma Breve Análise da Qualidade Temporal do Processo Civil Brasileiro e Europeu). Revista Jurídica da Universidade de Franca, Franca, ano 6, n. 11, 2003.

GARCETE, Carlos Alberto. Processo Civil: Reformas do Código. Editora Juarez de Oliveira, 2006.

GARCIA, Gustavo Filipe Barbosa. Terceira Fase da Reforma do Código de Processo Civil, Vol. 2. São Paulo: Editora Método, 2006.

GOMES JÚNIOR, Luiz Manoel; SANTOS FILHO, Ronaldo Fenelon. Julgamento antecipado em segundo grau. Limites para a aplicação do parágrafo 3. do art. 515 do CPC em sede de agravo de instrumento. Revista IOB de Direito Civil e Processual Civil, Porto Alegre: Síntese, vol. 46, p.184-191, mar./abr./2007.

GOMES, Magno Federici; SOUSA, Isabella Sandanha de. A efetividade do processo e a celeridade do procedimento sob o enfoque da teoria neo-institucionalista. Revista IOB de Direito Civil e Processual Civil, Porto Alegre, v.9, n.57, p.69-85, jan./fev. 2009. 
GRINOVER, Ada Pellegrini. A crise do Poder Judiciário. Revista de Direito Publico, São Paulo, v.24, n.98, p.18-26, abr./jun. 1991.

. A independência do juiz brasileiro. Revista de Processo, São Paulo, v.10, n.39, p.89-97, jul./set. 1985.

. Mudanças estruturais no processo civil brasileiro. Revista IOB de Direito Civil e Processual Civil, Porto Alegre, v.8, n.44, p.35-55, set./out. 2006.

- O controle do raciocínio judicial pelos tribunais superiores brasileiros. Ajuris: Revista da Associação dos Juízes do Rio Grande do Sul, Porto Alegre, v.17, n.50, p.5-20, nov. 1990.

. Teoria Geral do Processo (em coautoria). 20ª ed., São Paulo:

Malheiros Editores, 2004.

- Um enfoque constitucional da teoria geral dos recursos. Revista Jurídica, Porto Alegre, v.42, n.198, p.39-58, abr. 1994.

GUERRERO, Luis Fernando. Alternative Dispute Resolution e Adequação ao Momento Histórico - A questão do Acesso à Justiça, Bases Científicas para um renovado Direito Processual, vol.1, 2008.

HADDAD, Luiz Felipe da Silva. Celeridade da justiça: limites que se impõem. Revista da EMERJ, Rio de Janeiro, v.7, n.27, p. 228-33, 2004.

HELFELD, David M. El seminario sobre la demora judicial: diseño, resultados y recomendaciones. Revista Jurídica de la Universidad de Puerto Rico, Rio Piedras: La Escuela, v.77, n.4, p.891-914, 2008. 
HERRERO ACEVEDO, Luis S. La demora judicial en los foros de última instancia. Revista Jurídica de la Universidad de Puerto Rico, Rio Piedras: La Escuela, v.77, n.4, p.1055-72, 2008.

HESS, Heliana Coutinho. Acesso à Justiça por Reformas Judiciais. Campinas: Millennium Editora, 2004.

JOÃO, Ivone Cristina de Souza. O princípio constitucional da razoável duração dos processos e da celeridade processual. Revista da Faculdade de Direito de São Bernardo do Campo, São Paulo, v.11, n.13, p.207-28, 2007.

JORGE, Flávio Cheim. A Nova Disciplina do Recurso de Agravo: Lei ${ }^{\circ}$ 11.187, de 19/10/2005. Revista do Advogado, v. 85, pp. 131-148, mai/2006.

JORGE, Flávio Cheim. Apelação Cível: Teoria Geral e Admissibilidade. São Paulo: Editora Revista dos Tribunais, 1999. . Teoria Geral dos Recursos Cíveis. Rio de Janeiro: Editora Forense, 2003.

KARAM, Munir. Novos aspectos da apelação cível: o julgamento por salto de Instância do parágrafo 3. do art. 515. In: NERY JUNIOR, Nelson (coord.); WAMBIER, Teresa Arruda Alvim (coord.). Aspectos polêmicos e atuais dos recursos cíveis e assuntos afins. São Paulo: Revista dos Tribunais, 2006. p. 371-382.

KOEHLER, Frederico Augusto Leopoldino. As consequências da inclusão do princípio da razoável duração do processo na Constituição Federal de 1988, Revista Dialética de Direito Processual, São Paulo, n.73, p.47-62, abr. 2009. 
KOURY, Luiz Ronan Neves. Extinção do processo com julgamento do mérito: aplicação do artigo 515, $\S 3^{\circ}$ do CPC na hipótese. Revista Síntese de Direito Civil e Processual Civil, vol. 24, p.5-13, Jul./Ago./2003

KUKINA, Sérgio Luíz. O princípio do duplo grau de jurisdição. Revista de Processo, São Paulo, v.28, n.109, p.97-112, jan./mar. 2003.

LA CHINA, Sergio. Giusto processo, laboriosa utopia. Rivista di Diritto Processuale, Padova, v.60, n.4, p.1111-26, ott./dic. 2005.

LAPERTOSA, Flavio. Tribunale monocratico e collegiale nella riforma del processo civile. Rivista di Diritto Processuale, Padova, v.47, n.3, p.840-53, lug./sett. 1992.

LASPRO, Oreste Nestor de Souza. Duplo grau de jurisdição no direito processual civil. São Paulo: Revista dos Tribunais, 1995.

. Garantia do duplo grau de jurisdição. In TUCCI, José Rogério Cruz e (coord.). Garantias Constitucionais do Processo Civil - Homenagem aos 10 anos da Constituição Federal de 1988. São Paulo: Revista dos Tribunais, 1999.

. Os Recursos Ordinários na Reforma do Código de Processo Civil. Revista do Advogado, v. 46, ago/1995.

LEAL, Luciana de Oliveira. $\mathrm{O}$ acesso à justiça e a celeridade na tutela jurisdicional. Revista de Direito do Tribunal de Justiça do Estado do Rio de Janeiro, Rio de Janeiro, n.65, p.40-55, out./dez. 2005.

LEAL, Paulo J.B; ALEGRE, Valdir Porto. Duplo grau de jurisdição. Revista dos Tribunais, São Paulo, v.93, n.826, p.727-39, ago. 2004. 
LEVY, José Luiz. Fluência do prazo recursal contra liminar monocrática proferida em ação direta de inconstitucionalidade. Fórum Administrativo, Belo Horizonte, v.9, n.104, p.68-72, out. 2009.

LIEBMAN, Enrico Tullio. A força criativa da jurisprudencia e os limites impostos pelo texto da lei. Revista de Processo, São Paulo, v.11, n.43, p.57-60, jul./set. 1986.

; DINAMARCO, Cândido Rangel (trad.). Manual de Direito Processual Civil, Vol. I. 2a ed., Rio de Janeiro: Editora Forense, 1986.

LIMA, Fernando Rister de Sousa; CARBONE, Rodrigo Carrijo Mendes. A Uniformização da Jurisprudência Como Instrumento da Dogmática Jurídica. Revista IOB de Direito Civil e Processual Civil, Porto Alegre, v.11, n.64, p.101-9, mar/abr. 2010.

LIMA, Francisco Gerson Marques de. A jurisprudencia como fonte de direito. NOMOS: Revista do Curso de Mestrado de Direito da UFC, Fortaleza, v.11/12, n.1/2, p.249-63, jan./dez. 1992-1993.

LINS, Rodrigo Martiniano Ayres. A relativização do princípio do duplo grau cognitivo no processo civil brasileiro como instrumento de efetividade da tutela jurisdicional. Revista Forense, Rio de Janeiro, v.102, n.385, p.173-84, maio/jun. 2006.

LOPES, Gleydson Kleber Lopes de. Efeito devolutivo do recurso de apelação em face do novo parágrafo 3 do art. 515 do CPC. In: NERY JUNIOR, Nelson (coord.); WAMBIER, Teresa Arruda Alvim (coord.). Aspectos polêmicos e atuais dos recursos e de outros meios de impugnação às decisões judiciais. São Paulo: Revista dos Tribunais, 2002, p.229-262. 
LOPES, Raquel Cardoso. Uniformização da jurisprudência. Revista Forense, Rio de Janeiro, v.103, n.390, p.567-81, mar/abr. 2007.

LUCON, Paulo Henrique dos Santos. Art. 515, parágrafo 3., do Código de Processo Civil, ordem pública e prequestionamento. In: MEDINA, Jose Miguel Garcia (coord.); CRUZ, Luana Pedrosa de Figueiredo (coord.); CERQUEIRA, Luis Otavio Sequeira de (coord.); GOMES JUNIOR, Luiz Manoel (coord.). Os poderes do juiz e o controle das decisões judiciais: estudos em homenagem à Professora Teresa Arruda Alvim Wambier. São Paulo: Revista dos Tribunais, 2008, p.37-46.

O Novo Regime do Agravo: Lei $\mathrm{n}^{\mathrm{o}}$ 11.187/2005. Revista do Advogado, v. 85, mai/2006.

MACHADO, Agapito. O advogado e o relator nos tribunais. Revista dos Tribunais, São Paulo, v.83, n.710, p.224-5, dez. 1994.

MACHADO, Denise Maria Weiss de Paula; LEAL JÚNIOR, João Carlos. Análise crítica do duplo grau de jurisdição sob o prisma do direito à razoável duração do processo. Revista de Processo, São Paulo, v.35, n.183, p.77-118, maio. 2010.

MACHADO, Fabio Cardoso. Da uniformização jurídico-decisória por vinculação às sumulas de jurisprudência: objeções de ordem metodológica, sócio-cultural e político-jurídica. Revista de Processo, São Paulo, v.30, n.124, p.123-48, jun. 2005.

MACHADO, Hugo de Brito. A reserva de plenário e a decisão cautelar monocrática nos tribunais. Revista Dialética de Direito Processual, São Paulo, n.87, p.65-70, jun. 2010.

MANCUSO, Rodolfo de Camargo. A Jurisprudencia, dominante ou sumulada, e sua eficácia contemporânea. Revista do Tribunal de Contas do Município de São Paulo, São Paulo, v.1, n.3, p.40-7, ago. 1999. 
MARCATO, Ana Cândida Menezes. O Princípio do Duplo Grau de Jurisdição e a Reforma do CPC. São Paulo: Ed. Atlas, 2006.

MARCATO, Antonio Carlos (coord.). Código de Processo Civil interpretado. São Paulo : Atlas, 2004.

- A imparcialidade do juiz e a validade do processo. Revista Direito Mackenzie, São Paulo, v.1, n.2, p.65-99, jul./dez. 2000.

. Considerações sobre a tutela jurisdicional diferenciada. Disponível em http://www.mundojuridico.adv.br/sis_artigos/artigos.asp?codigo=249. Acesso em 30.3.2010

MARINHO FILHO, Luciano. Paralelo analítico entre mecanismos de uniformização de jurisprudência no direito processual pátrio. Revista Dialética de Direito Processual, São Paulo, n.90, p.54-65, set. 2010.

MARINONI, Luiz Guilherme. Ações Repetitivas e Julgamento Liminar. Revista dos Tribunais, São Paulo: Editora Revista dos Tribunais, ano 96, n. 858, abr/2007.

. Direito fundamental à duração razoável do processo. Revista Jurídica, Porto Alegre, v.57, n.379, p.11-27, maio. 2009.

. Manual do Processo de Conhecimento. $2^{\mathrm{a}}$ ed., São Paulo: Editora Revista dos Tribunais, 2003.

. Tutela Antecipatória, Julgamento Antecipado e Execução Imediata da Sentença. $4^{\mathrm{a}}$ ed., São Paulo: Editora Revista dos Tribunais, 2000. 
MARQUES, José Frederico. Instituições de Direito processual civil. Campinas: Millenium, 1999.

MARTINS FILHO, Ives Gandra da Silva. A garantia constitucional da celeridade processual e os recursos protelatórios. Revista de Direito Administrativo, Rio de Janeiro, n.243, p.71-8, set./dez. 2006.

MARTINS, Francisco Peçanha A reforma no artigo 557 do código de processo civil. Inconstitucionalidade e ilegalidade. Revista do Instituto dos Advogados de São Paulo, São Paulo: Revista dos Tribunais, vol. 5, p.51-59, jan./jun./2000.

- Exame do artigo 557 do código de processo civil. Revista de Processo, São Paulo: Revista dos Tribunais, vol. 102, p.153-166, abr/jun/2001.

MARTINS, Ives Gandra da Silva. A jurisprudencia integrativa e o ideal de justiça. Boletim da Faculdade de Direito da Universidade de Coimbra, numero especial, estudos em homenagem a A. Ferrer-Correia. n.3, p.85-99, 1991.

MATTOS, Sérgio Luís Wetzel de. O processo justo na Constituição Federal de 1988, Revista da AJURIS, Porto Alegre, v.30, n.91, p.215-60, set. 2003.

MEDINA, Paulo Roberto de Gouvêa. Os valores celeridade processual e segurança jurídica no projeto de novo Código de Processo Civil. Revista de Informação Legislativa, Brasília, v.48, n.190 t.2, p.169-77, abr./jun. 2011.

MELO, Ricardo Procópio Bandeira de. Princípio do duplo grau de jurisdição: garantia constitucional, extensão e algumas notas sobre o parágrafo $3^{\circ}$ do art. 515 do CPC. In: NERY JUNIOR, Nelson (coord.); WAMBIER, Teresa Arruda Alvim (coord.). Aspectos polêmicos e atuais dos recursos cíveis e de outros meios de impugnação às decisões judiciais. São Paulo: Revista dos Tribunais, 2005. p.661-692. 
MENDES, Claudia Brodt; RAGAZZI, José Luiz. Constitucionalidade da supressão do duplo grau de jurisdição: artigo 515, parágrafo 3. do CPC. Revista do Instituto de Pesquisas e Estudos. Divisão Jurídica, Bauru: Instituição Toledo de Ensino, vol. 48, p.325-336, jul./dez./2007

MENDES, Francisco de Assis Filgueiras. A uniformização da jurisprudencia. Revista da Faculdade de Direito. Universidade Federal do Ceara, Fortaleza, v.31, n.1, p.171-77, jan./jun. 1990.

MENDONÇA, Paula Oliveira. Princípios processuais, importância de seu estudo para o direito processual. Revista da Esmape, Recife, v.4, n.9, p.301-41, jan./jun. 1999.

MILLER, Arthur R. From Conley to Twombly to Iqbal: a double play on the federal rules of civil procedure. Duke Law Journal, Durham, v.60, n.1, p.1-130, Oct. 2010.

MINISTÉRIO DA JUSTIÇA. Diagnóstico do Poder Judiciário. Disponível em http://www.mj.gov.br/reforma/pdf/publicacoes/diagnostico_web.pdf . Acesso em 11.10.10.

MIRANDA NETTO, Fernando Gama de. Leitura garantista do recurso na história do direito processual civil. Revista da Faculdade de Direito Cândido Mendes, Rio de Janeiro, v.9, n.9, p.173-86, 2004.

MIRANDA, Pontes de. Comentários ao Código de Processo Civil. 3. Ed. Atual por Sérgio Bermudes. Rio de Janeiro: Forense, 1999, t. 7.

MOLLICA, Rogério. O Excesso de Formalismo como obstáculo à celeridade processual. Bases Científicas para um renovado Direito Processual, vol.1, pp. 375-407, 2008. 
MÔNACO DA SILVA, José Luiz. Comentários às Reformas Processuais Civis. São Paulo: Editora Universitária de Direito, 2006.

MONTEIRO NETO, Nelson. Agravo de instrumento, decisão do relator e garantia do contraditório. Revista Dialética de Direito Processual, São Paulo, n.85, p.73-8, abr. 2010.

NALINI, Jose Renato. Processo e procedimento - distinção e a celeridade da prestação jurisdicional. Revista dos Tribunais, São Paulo, v.85, n.730, p.673-88, ago. 1996.

NASCIMBENE, Bruno; SANNA, Cecilia. L'eccessiva durata dei processi in Itália e le conseguenze a livello europeo. Sociologia del Diritto, Milano, v.30, n.1, p.121-57, 2003.

NEGRÃO, Theotonio (em coautoria). Código de Processo Civil e Legislação Processual em Vigor. São Paulo: Editora Saraiva, 2007.

NERY JR., Nelson. Código de Processo Civil Comentado e Legislação Extravagante. 9a ed., São Paulo: Editora Revista dos Tribunais, 2006.

- Reflexões sobre o Sistema dos Recursos Cíveis na Reforma Processual Civil de 1994. Revista de Processo, v. 79, pp. 118-133, jul./set/1995.

. Princípios do processo civil na Constituição Federal. São Paulo:

Revista dos Tribunais, 2004.

. Princípios fundamentais: teoria geral dos recursos. 5. Ed., São

Paulo: RT, 2000.

; WAMBIER, Teresa Arruda Alvim (coords.). Aspectos Polêmicos e Atuais dos Recursos Cíveis e de outros Meios de Impugnação às Decisões Judiciais. São Paulo: Editora Revista dos Tribunais, 2003. 
NIETO, Alejandro. Valor legal y alcance real de la jurisprudencia. Teoría y Realidad Constitucional, Madrid, n.8/9, p.103-16, 2001-2002.

NOGUEIRA, Gustavo Santana. Jurisprudência vinculante no direito norte-americano e no direito brasileiro. Revista de Processo, São Paulo, v.33, n.161, p.101-14, jul. 2008.

NOGUEIRA, Mauricio José. Duplo grau de jurisdição: aspectos constitucionais e reflexos processuais. In FUX, Luiz; NERY JUNIOR, Nelson; WAMBIER, Teresa Arruda Alvim. Processo e constituição: estudos em homenagem ao professor José Carlos Barbosa Moreira. São Paulo: Revista dos Tribunais, 2006.

NORRIS, Roberto. Do acesso à Justiça e a morosidade na prestação da atividade jurisdicional: crise do princípio do duplo grau de jurisdição e as súmulas vinculantes. LTr: revista legislação do trabalho, São Paulo, v.64, n.12, p.1529-37, dez. 2000.

NOTARIANO JUNIOR, Antonio de Pádua. O duplo grau e o paragrafo 3 do artigo 515 do CPC, introduzido pela lei 10.352/01. Revista de Processo, São Paulo: Revista dos Tribunais, vol. 114, p.187-207, mar./abr./2004.

NUNES, Dierle José Coelho; BAHIA, Alexandre Gustavo Melo Franco. Eficiência processual: algumas questões. Revista de Processo, São Paulo, v.34, n.169, p.116-39, mar. 2009.

. Colegialidade das decisões dos tribunais - sua visualização como princípio constitucional e do cabimento de interposição de agravo interno de todas as decisões monocráticas do relator. Revista IOB de Direito Civil e Processual Civil, Porto Alegre, v.9, n.50, p.50-61, nov./dez. 2007.

Comentários acerca da Súmula Impeditiva de Recursos (Lei 11.276/2006) e do Julgamento Liminar de Ações Repetitivas (Lei 11.277/2006) - do Duplo Grau de Jurisdição e do Direito Constitucional a Recurso (Contraditório Sucessivo) - 
Aspectos Normativos e Pragmáticos. Revista de Processo, São Paulo: Editora Revista dos Tribunais, ano 31, n. 137, jul./2006.

OBARA, Hilbert Maximiliano A. Celeridade e efetividade do processo. Revista da AJURIS, Porto Alegre, v.30, n.90, p.145-56, jun. 2003.

OLIANI, José Alexandre Manzano. Considerações sobre a inconstitucionalidade da irrecorribilidade da decisão liminar do relator que atribui efeito suspensivo ou antecipa a tutela recursal no agravo de instrumento e do juízo de reconsideração, positivados pela lei 11.187 de 19.10.2005. In: FUX, Luiz; NERY JUNIOR, Nelson (coord.); WAMBIER, Teresa Arruda Alvim (coord.). Processo e constituição: estudos em homenagem ao professor José Carlos Barbosa Moreira. São Paulo: Revista dos Tribunais, 2006. p.1022-1042.

OLIVEIRA, Celso Marcelo. Moderno Direito Processual Civil do Brasil e Portugal. Boletim Jurídico, Uberaba/MG, a. 4, no 151. Disponível em: <http://www.boletimjuridico.com.br/ doutrina/texto.asp?id=903> Acesso em 30.3.2010

OLIVEIRA, Pedro Miranda de. Agravo interno e agravo regimental: hipóteses de incidência e poderes do relator nos tribunais. São Paulo: Revista dos Tribunais, 2009.

Apontamentos sobre os poderes do relator nos Tribunais. In: NERY JUNIOR, Nelson (coord.); WAMBIER, Teresa Arruda Alvim(coord.). Aspectos polêmicos e atuais dos recursos cíveis e assuntos afins. São Paulo: Revista dos Tribunais, 2006, p.430-465.

- O cabimento direto de recurso excepcional contra a decisão monocrática de conversão do agravo de instrumento em agravo retido. Revista de Processo, São Paulo, v.33, n.165, p.201-04, nov. 2008. 
. Poderes do relator no agravo de instrumento: impossibilidade de provimento singular sem a oitiva da parte agravada. Revista Dialética de Direito Processual, São Paulo, n.81, p.89-98, dez. 2009.

PASSOS, Paulo Roberto da Silva. Algumas reflexões sobre o duplo grau de jurisdição. Revista de Processo, São Paulo, v.18, n.69, p.155-9, jan/mar. 1993.

PEDRA, Adriano Sant'Ana. A natureza principiológica do duplo grau de jurisdição. Revista de Direito Administrativo, Rio de Janeiro, n.247, p.13-30, jan./abr. 2008.

PEIXOTO, Aguimar Martins. Principio do duplo grau de jurisdição e a celeridade processual. Trabalho e Doutrina: processo jurisprudencia, São Paulo, n.21, p.52-9, jun. 1999.

PEREIRA, Milton Luiz. Embargos de divergência contra decisão lavrada por relator. Revista Forense, Rio de Janeiro, v.99, n.366, p.375-9, mar./abr. 2003.

PERONE, Gian Carlo. A importância da Jurisprudencia no direito italiano e na Comunidade Europeia. Revista do Tribunal Regional do Trabalho da 15a. Região, Campinas, n.10, p.9-14, jan./mar. 2000.

PINHEIRO FILHO, Renato. O princípio da oralidade no processo civil: a utilização da forma de comunicação oral e a concentração dos atos processuais numa perspectiva de conferir maior celeridade ao processo. Revista da Esmape, Recife, v.4, n.10, p.305-30, jul./dez. 1999.

PINHEIRO, Guilherme César. Uma crítica às intermináveis reformas processuais: por uma compreensão constitucionalmente adequada da razoável duração do procedimento e da efetividade do processo. Revista de Estudos Jurídicos da UNESP, Franca, v.14, n.19, p.37595, 2010. 
PINTO, Christian Barros. Provimentos liminar do agravo de instrumento pelo relator. Revista Dialética de Direito Processual, São Paulo, n.97, p.16-24, abr. 2011.

PINTO, Nelson Luiz. Manual dos recursos cíveis. 2ª ed., São Paulo: Malheiros, 2000. . Recurso especial e recurso extraordinário - a Lei 8.038, de 28.5.90 e as alterações no Código de Processo Civil. Revista de Processo, n. 57.

- Suspeição de juiz relator. Universitária: Revista do Curso de Mestrado em Direito, Araçatuba, v.2, n.1, p.183-208, dez. 2001.

PIRES, Renato Barth. A reforma do Poder Judiciário e o direito à razoável duração do processo. Revista do Tribunal Regional Federal. $3^{a}$ Região, São Paulo, n.62, p.25-30, nov./dez. 2003.

POZZA, Pedro Luiz. Considerações sobre a lei 9.756/98. Ajuris, 75.

PUOLI, José Carlos Baptista. Os poderes do juiz e as reformas do processo civil. São Paulo: Juarez de Oliveira, 2002.

RAMOS, Glauco Gumerato (em coautoria). Reforma do CPC. São Paulo: Editora Revista dos Tribunais, 2006.

REDENTI, Enrico. Diritto processuale civile. $4^{\mathrm{a}}$ ed., Milano: Giuffrè, 1997, v. 2.

RICCI, Edoardo F.. Doppio grado di giurisdizione (principio del). Enciclopedia Giuridica, $v$. 12, Rivista di Diritto Processuale XXXIII, 1978, pp. 59/85.

RIVERA, Milvia A. Mecanismos de eficiência del Tribunal de Apelaciones de Puerto Rico y el Tribunal de Apelaciones Federal para el Primer Circuito ante el problema de la demora judicial. Revista Jurídica de la Universidad de Puerto Rico, Rio Piedras: La Escuela, v.77, n.4, p.1001-33, 2008. 
RODRIGUES, Clóvis Fedrizzi. Celeridade processual versus segurança jurídica. Revista de Processo, São Paulo, v.30, n.120, p.289-99, fev. 2005.

. Direito fundamental à duração razoável do processo. Revista IOB de Direito Civil e Processual Civil, Porto Alegre, v.11, n.63, p.80-92, jan./fev. 2010.

RODRIGUES, Rosmar Antonni; ALENCAR, Cavalcanti de. Procedimento ordinário e razoável duração do processo. Revista Forense, Rio de Janeiro, v.104, n.395, p.251-80, jan/fev. 2008.

RODRIGUES, Walter Piva. O princípio da colegialidade das decisões nos tribunais. Revista Dialética de Direito Processual, São Paulo, n.1, p.176-8, abr. 2003.

- Responsabilidade da Magistratura: o Agravo de Instrumento e a "Reforma" de suas Reformas Legislativas. Revista do Advogado, v. 84, pp. 232/236, dez/2005.

ROMEIRO, Marcio Anatole de Sousa. Celeridade ou Duração Razoável do Processo: Do Princípio ao Direito. Revista Forense, Rio de Janeiro, v.104, n.397, p.221-46, mai/jun. 2008.

ROSAS, Roberto. Segurança jurídica. Efetividade. Jurisprudência. Revista de Informação Legislativa, Brasília, v.48, n.190 t.2, p.215-20, abr./jun. 2011.

ROSITO, Francisco. O princípio da duração razoável do processo sob a perspectiva axiológica. Revista de Processo, São Paulo, v.33, n.161, p.21-38, jul. 2008.

SADEK, Maria Tereza. Judiciário: Mudanças e Reformas. Estudos Avançados, São Paulo, Instituto de Estudos Avançados da USP, mai/ago/2004. 
- Justiça em Números: Novos Ângulos. Disponível em http://www.amb.com.br/docs/noticias/2009/AMB_Sadek_Justica_em_numeros_novos_angulo s.pdf . Acesso em 12.10.10.

SADURSKI, Wojciech. Judicial review and the protection of constitutional rights. Oxford Journal of Legal Studies, Oxford, v.22, n.2, p.275-99, 2002.

SAGARDÍA ABREU, Carlos J. Consideraciones generales sobre la demora judicial en el Tribunal de Primera Instancia. Revista Jurídica de la Universidad de Puerto Rico, Rio Piedras: La Escuela, v. 77, n.4, p.961-99, 2008.

SALVANESCHI, Laura. La riduzione del tempo del processo nella nuova riforma dei primi due libri del codice di rito. Rivista di Diritto Processuale, Padova, v. 64, n.6, p.1560-81, nov. /dic. 2009.

SANTIAGO AMARO, Cristina. La demora en el sistema judicial de Puerto Rico: enfoque en casos de derecho constitucional. Revista Jurídica de la Universidad de Puerto Rico, Rio Piedras: La Escuela, v. 77, n.4, p.1073-117, 2008.

SANTIS, Francesco de. La ragionevole durata, l'applicazione della norma processuale e la rimessione in termini: percorsi per un processo d'inizio secolo. Rivista di Diritto Processuale, Padova, v. 64, n.4, p.875-96, luglio/ag. 2009.

SANTOS NETO, João Antunes dos. Unicidade e dualidade de jurisdição. Revista da Escola Paulista da Magistratura, São Paulo, v. 4, n.2, p.129-47, jul./dez. 2003.

SHIMURA, Sérgio. Reanálise do duplo grau de jurisdição obrigatório diante das garantias constitucionais. In FUX, Luiz; NERY JUNIOR, Nelson; WAMBIER, Teresa Arruda Alvim. Processo e constituição: estudos em homenagem ao professor José Carlos Barbosa Moreira. São Paulo: Revista dos Tribunais, 2006. 
SILVA, Carlos Manuel Ferreira da. Breves notas sobre uniformização da jurisprudência cível em Portugal. Revista de Processo, São Paulo, v. 29, n.117, p.193-202, set./out. 2004.

SILVA, Eider Avelino. O art. 557 do CPC e a necessidade de contraditório: análise da jurisprudência do Superior Tribunal de Justiça. Revista de Processo, São Paulo, v. 36, n.196, p.367-81, jun. 2011.

SILVA, João Carlos Pestana de Aguiar. A sumula vinculante como um retrocesso perante a histórica evolução da Jurisprudencia. Revista dos Tribunais, São Paulo, v. 89, n.773, p.38-51, mar. 2000.

SILVA, José Antonio Ribeiro de Oliveira. O princípio do duplo grau de jurisdição. Revista do Tribunal Regional do Trabalho da 15a. Região, Campinas, n.11, p.155-60, 2000.

SILVA, Mario Teixeira da. Recursos cíveis e poderes do relator. 2.ed. atual, Curitiba: Juruá, 2006

SILVA, Ovídio A. Baptista da. Tempo do processo e regulação da sucumbência. Revista Dialética de Direito Processual, São Paulo, n.7, p.68-77, out. 2003.

- Processo e Ideologia. Revista de Processo, São Paulo: Editora Revista dos Tribunais, ano 28, n. 110, abr/jun/2003.

. Teoria geral dos recursos cíveis. In GOMES, Fabio Luiz; SILVA, Ovídio Araújo Baptista da. Teoria geral do processo civil. São Paulo: Revista dos Tribunais, 2010. 
SIQUEIRA FILHO, Elio Wanderley de. Recursos e celeridade processual. Revista Trimestral de Jurisprudencia dos Estados, São Paulo, v. 19, n.141, p.47-64, out. 1995.

SIRACUSANO, Delfino. Ragionevole durata del processo e giudizi di impugnazione. Rivista Italiana di Diritto e Procedura Penale, Milano, v. 49, n.1, p.16-28, genn./mar. 2006.

SLAIBI FILHO, Nagib. Direito fundamental à razoável duração do processo judicial e administrativo. Revista da EMERJ, Rio de Janeiro, v. 3, n.10, p.118-42, 2000.

SLAIBI FILHO, Nagib. Notas sobre o art. 557 do CPC (competência do relator de prover e negar seguimento a recurso). Revista Forense, Rio de Janeiro, v. 98, n.361, p.95-107, maio/jun. 2002.

SOARES, Carlos Henrique. Considerações preliminares sobre o relatório do novo Código de Processo Civil. IOB - Repertório de Jurisprudência: Civil, Processual, Penal e Comercial, São Paulo, v. 3, n.13, p.398-391, jul. 2010.

STRECK, Lenio Luiz. A Hermenêutica Jurídica e o Efeito Vinculante da Jurisprudência no Brasil: o Caso das Súmulas. Boletim da Faculdade de Direito da Universidade de Coimbra, Coimbra, v. 82, p.213-37, 2006.

STRICKLER, Yves. L'execution des jugements et le double degre en matiere civile. Justices: revue generale de droit processuel, Paris, n.4, p.127-37, juil./dec. 1996.

TAKOI, Sérgio Massaru. A decisão do relator no novo regime do agravo de instrumento: Lei 11.187/05 e o mandado de segurança. In: ALVIM, Arruda (coord.); ALVIM, Eduardo Arruda (coord.). Atualidades do processo civil. Curitiba: Juruá, 2007, p.27-35.

TALAMINI, Eduardo. Manifestação do Professor Eduardo Talamini sobre a Reforma do CPC. Disponível em http://www.migalhas.com.br/Quentes/17,MI106902,41046Manifestacao+do+Professor+Eduardo+Talamini+sobre+a+reforma+do+CPC. Acesso em 14.10.10. 
TAMOYO Y SALMORÁN, Rolando. Jurisprudencia y formulación judicial del derecho. ISONOMIA: Revista de Teoría y Filosofía del Derecho, México, n.21, p.193-215, oct. 2004.

TARZIA, Giuseppe. La durata del processo civile e la tutela dei deboli. Rivista di Diritto Processuale, Padova, v. 60, n.2, p.317-28, apr./giug. 2005.

TAVARES, André Ramos. Analise do duplo grau de jurisdição como principio constitucional. Revista de Direito Constitucional e Internacional, São Paulo, v. 8, n.30, p.177-86, jan./mar. 2000.

TEIXEIRA, Sálvio de Figueiredo. A Efetividade do Processo e a Reforma Processual. Revista de Processo, São Paulo: Editora Revista dos Tribunais, ano 20, n. 78, , abr/jun/1995.

As tendências brasileiras rumo a Jurisprudencia vinculante. Revista do Instituto dos Advogados de São Paulo, São Paulo, v. 1, n.2, p.145-57, jul./dez. 1998.

TESHEINER, José Maria Rosa. Confirmação de despachos e sentenças por decisão do relator. Anais do VII Encontro dos Tribunais de Alçada do Brasil. São Paulo: Tribunal de Alçada Criminal de São Paulo, 1985, p.199-200.

. Em Tempo de Reformas: O Reexame de Decisões Judiciais. Revista de Processo, v. 147, mai/2007.

TESHEINER, Jose Maria Rosa. Uniformização de jurisprudência. Ajuris: Revista da Associação dos Juízes do Rio Grande do Sul, Porto Alegre, v. 17, n.50, p.178-83, nov. 1990. 
THEODORO JÚNIOR, Humberto. As Novas Reformas do Código de Processo Civil. Rio de Janeiro: Editora Forense, 2006.

. Celeridade e efetividade da prestação jurisdicional. Insuficiência da reforma as leis processuais. Revista Síntese de Direito Civil e Processual Civil, Porto Alegre, v. 6, n.36, p.19-37, jul./ago. 2005.

. Curso de Direito Processual Civil - Teoria Geral do direito processual civil e processo de conhecimento, Rio de Janeiro: Forense, 2009.

erto. Reforma do CPC: inovações da lei $\mathrm{n}^{\circ}$ 10.352/2001, em matéria de recursos cíveis e duplo grau de jurisdição. Revista Síntese de Direito Civil e Processual Civil, Porto Alegre, v. 4, n.20, p.126-40, nov./dez. 2002.

TOSTES, Natacha Nascimento Gomes. Uniformização de jurisprudência. Revista de Processo, São Paulo, v.26, n.104, p.194-218, out./dez. 2001.

TUCCI, José Rogério Cruz e. Garantia do processo sem dilações indevidas. Revista Jurídica, $\mathrm{n}^{\circ} 277$, nov. 2000.

- Garantias constitucionais da duração razoável e da economia processual no projeto do Código de Processo Civil, Revista de Processo, São Paulo, v.36, n.192, p.193-209, fev. 2011.

. Sobre a atividade decisória do relator do agravo de instrumento. Revista Forense, Rio de Janeiro, v.93, n.338, p.411-4, abr./jun. 1997. . Tempo e Processo. São Paulo: Editora Revista dos Tribunais, 1997. 
VAZ, Paulo Afonso Brum. Breves considerações acerca do novo parágrafo 3. do art. 515 do CPC. Revista de Processo, São Paulo: Revista dos Tribunais, vol. 134, p.88-96, abr./2006.

VECHIATO JR., Walter. Processo Civil: Reformas e Atualidades. Editora Juarez de Oliveira, 2006.

VELASCO, Ignácio Maria Poveda. Direito, jurisprudência e justiça no pensamento clássico (grego-romano). Revista da Faculdade de Direito da Universidade de São Paulo, São Paulo, v.101, p.21-32, jan./dez. 2006.

VERDE, Giovanni. Giudice monocratico e collegiale (divagazioni su Costituzione e processo). Rivista di Diritto Processuale, Padova, v.46, n.4, p.942-64, ott./dic. 1991.

. Il processo sotto l'incubo della ragionevole durata. Rivista di Diritto Processuale, Padova, v.66, n.3, p.505-29, magg./giugno. 2011.

VICARI, Marcio Luiz Fogaça. Antecipação da tutela recursal e competência do relator. Revista Forense, Rio de Janeiro: Forense, vol. 353, p. 207-217, jan./fev./2001.

VIEIRA, Luciana Guimarães Pinheiro. A efetividade do sistema recursal brasileiro. Revista da Procuradoria Federal Especializada - INSS, Brasília, v.9, n.3, p.94-100, out./dez. 2002.

VIGORITI, Vincenzo. Notas sobre o custo e a duração do processo civil na Itália. Revista de Processo, São Paulo, v.11, n.43, p.142-48, jul./set. 1986,

VIVEIROS, Estefânia. Agravo interno no Superior Tribunal de Justiça e ampliação dos poderes do relator. Universitas/Jus, Brasília, n.7, p.59-88, jul./dez. 2001. 
WAMBIER, Luiz Rodrigues. A Reforma do Código de Processo Civil. Revista de Processo, v. 87, jul./set1997.

. Teoria geral dos recursos. Revista de Processo, vol. 164, out./2008.

. Uma proposta em torno do conceito de Jurisprudência dominante.

Revista de Processo, São Paulo, v.25, n.100, p.81-7, out./dez. 2000.

; ARRUDA ALVIM WAMBIER, Teresa; MEDINA, José Miguel

Garcia. Breves comentários à nova sistemática processual civil: Emenda Constitucional $n$. 45/2004 (reforma do Judiciário); Lei 10.444/2002; Lei 10.358/2001 e Lei 10.352/2001. 3. ed. Rev. Atual. E ampli. São Paulo: Ed. RT, 2005.

WAMBIER, Teresa Arruda Alvim. A uniformidade e a estabilidade da jurisprudência e o Estado de direito civil law e common law. Revista Jurídica, Porto Alegre, v.57, n.384, p.5362 , out/2009.

. Os agravos no CPC brasileiro. São Paulo: RT, 2006.

; WAMBIER, Luiz Rodrigues; MEDINA, José Miguel Garcia.

Breves Comentários à Nova Sistemática Processual Civil 2: Leis 11.187/2005, 11.232/2005, 11.276/2006, 11.277/2006, 11.280/2006. São Paulo: Editora Revista dos Tribunais, 2006.

WATANABE, Kazuo. Acesso à justiça e sociedade moderna. In GRINOVER, Ada Pellegrini et. al. Participação e processo. São Paulo: Editora Revista dos Tribunais, 1988.

- Da Cognição no Processo Civil. São Paulo: Editora Revista dos Tribunais, 1987. 
YARSHELL, Flávio Luiz. A reforma do Judiciário e a promessa de duração razoável do processo. Revista do Advogado, São Paulo, v.24, n.75, p.28-33, abr. 2004.

. Tutela Jurisdicional. São Paulo: Editora Atlas, 1999.

; MORAIS, Maurício Zanoide de (org.). Estudos em Homenagem à Professora Ada Pellegrini Grinover. São Paulo: DPJ Editora, 2005.

ZACCARIA, Giuseppe. La jurisprudencia como fuente de derecho: una perspectiva hermenéutica. Isonomía: revista de teoria y filosofia de derecho, México, n.32, p.93-117, abr. 2010. 
